Nevada

Environmental Management

Operations Activity

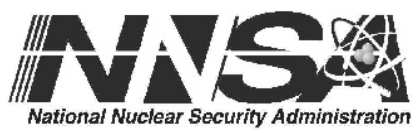

Closure Report for

Corrective Action Unit 562:

Waste Systems,

Nevada National Security Site,

Nevada

Controlled Copy No.:

Revision: 0

August 2012 


\section{DISCLAIMER}

Reference herein to any specific commercial product, process, or service by trade name, trademark, manufacturer, or otherwise, does not necessarily constitute or imply its endorsement, recommendation, or favoring by the United States Government or any agency thereof.

This report has been reproduced directly from the best available copy.

Available for sale to the public from:

U.S. Department of Commerce

National Technical Information Service

5301 Shawnee Road

Alexandria, VA 22312

Telephone: (800) 553-6847

Fax: (703) 605-6900

E-mail: orders@ntis.gov

Online ordering: http://www.ntis.gov/help/ordermethods.aspx

Available electronically at http://www.osti.gov/bridge.

Available for a processing fee to the U.S. Department of Energy and its contractors, in paper, from:

U.S. Department of Energy

Office of Scientific and Technical Information

P.O. Box 62

Oak Ridge, TN 37831-0062

Telephone: (865) 576-8401

Fax: (865) 576-5728

E-mail: reports@adonis.osti.gov 


\title{
CLOSURE REPORT FOR CORRECTIVE ACTION UNIT 562: WASTE SYSTEMS, NEVADA NATIONAL SECURITY SITE, NEVADA
}

\author{
U.S. Department of Energy \\ National Nuclear Security Administration \\ Nevada Site Office \\ Las Vegas, Nevada
}

Controlled Copy No.

Revision: 0

August 2012 
THIS PAGE INTENTIONALLY LEFT BLANK 


\section{CLOSURE REPORT FOR CORRECTIVE ACTION UNIT 562: WASTE SYSTEMS, NEVADA NATIONAL SECURITY SITE, NEVADA}

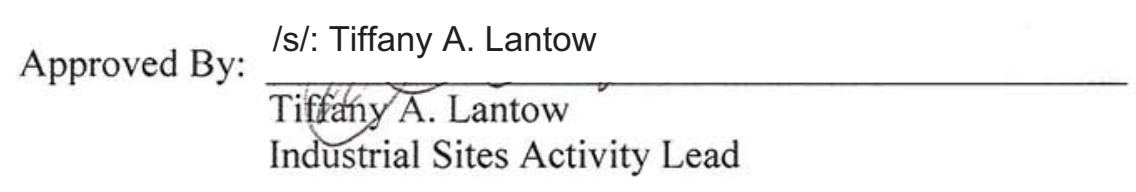

Approved By: /s/: Robert F. Boehlecke

Robert F. Boehlecke

Environmental Management Operations Activity Manager
Date: $8 / 15 / 2012$

Date: $8 / 15 / 20 / 2$ 
THIS PAGE INTENTIONALLY LEFT BLANK 


\section{TABLE OF CONTENTS}

ACRONYMS AND ABBREVIATIONS .......................................................................................................vii

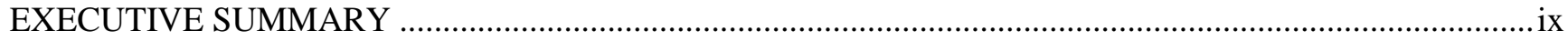

1.0 INTRODUCTION

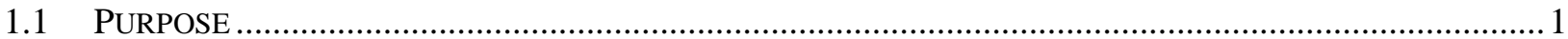

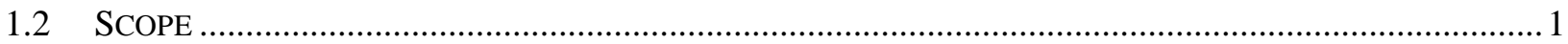

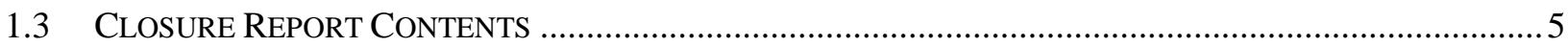

1.3.1 Applicable Programmatic Plans and Documents ............................................................. 5

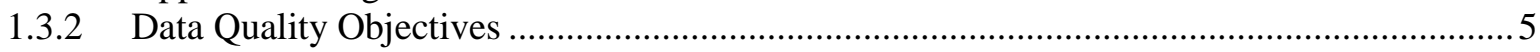

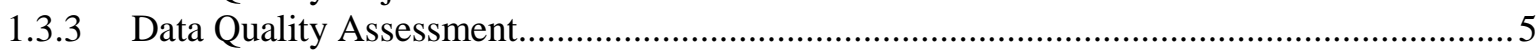

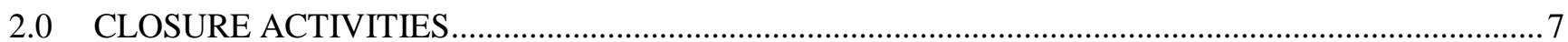

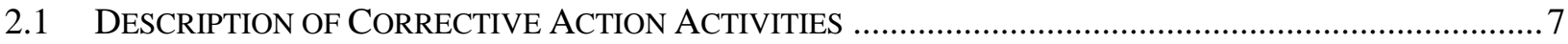

2.1.1 Corrective Action Site 02-26-11, Lead Shot .................................................................... 7

2.1.2 Corrective Action Site 02-44-02, Paint Spills and French Drain ....................................... 7

2.1.3 Corrective Action Site 02-59-01, Septic System........................................................... 7

2.1.4 Corrective Action Site 02-60-01, Concrete Drain ......................................................... 7

2.1.5 Corrective Action Site 02-60-02, French Drain .......................................................... 7

2.1.6 Corrective Action Site 02-60-03, Steam Cleaning Drain ................................................ 8

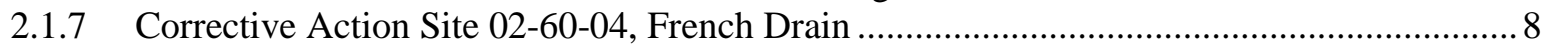

2.1.8 Corrective Action Site 02-60-05, French Drain .............................................................. 8

2.1.9 Corrective Action Site 02-60-06, French Drain .............................................................. 8

2.1.10 Corrective Action Site 02-60-07, French Drain ............................................................. 8

2.1.11 Corrective Action Site 23-60-01, Mud Trap Drain and Outfall ......................................... 8

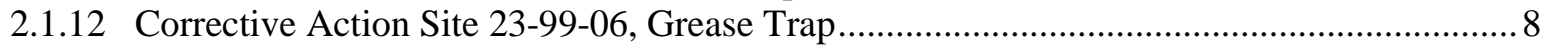

2.1.13 Corrective Action Site 25-60-04, Building 3123 Outfalls............................................... 8

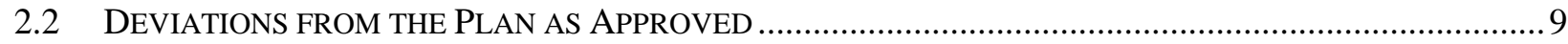

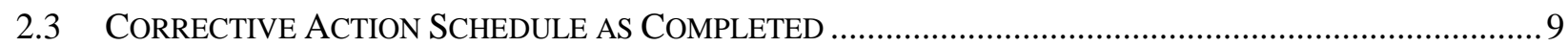

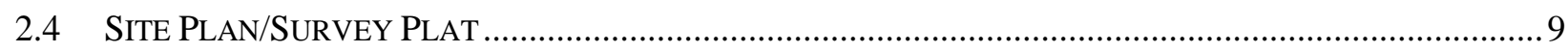

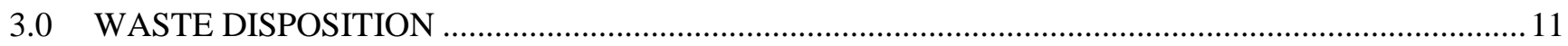

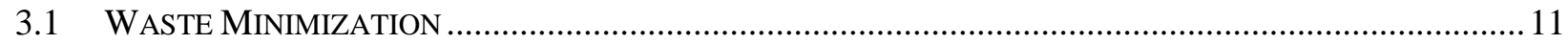

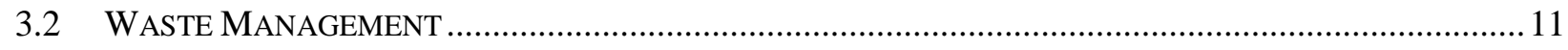

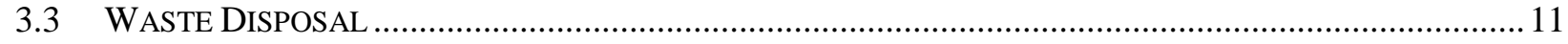

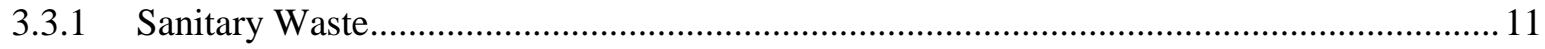

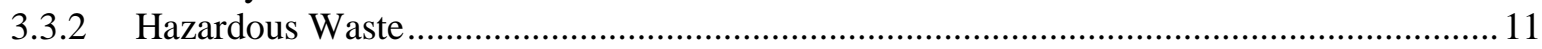

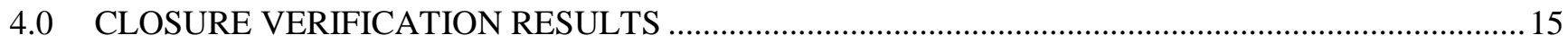

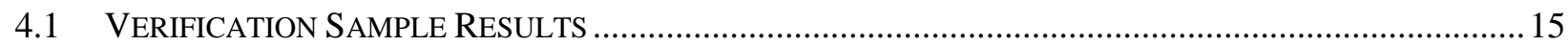

4.1.1 Corrective Action Site 02-44-02, Paint Spills and French Drain ....................................... 15

4.1.2 Corrective Action Site 02-60-03, Steam Cleaning Drain ................................................... 15

4.1.3 Corrective Action Site 02-60-05, French Drain ................................................................. 16

4.1.4 Corrective Action Site 25-60-04, Building 3123 Outfalls................................................... 17

4.2 DATA QUALITY ASSESSMENT .......................................................................................... 18

4.2.1 Quality Assurance and Quality Control Procedures....................................................... 18

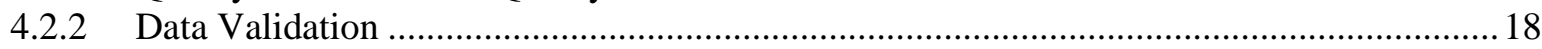

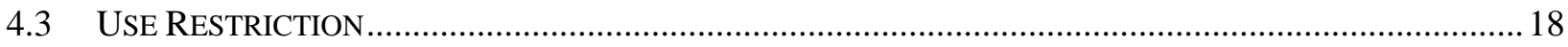




\section{TABLE OF CONTENTS (continued)}

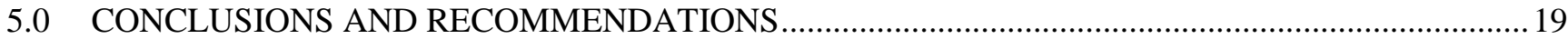

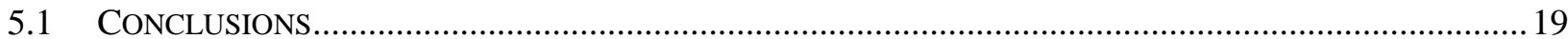

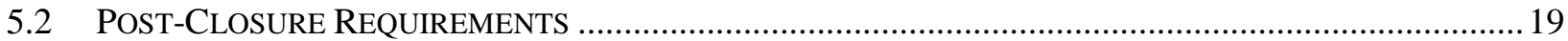

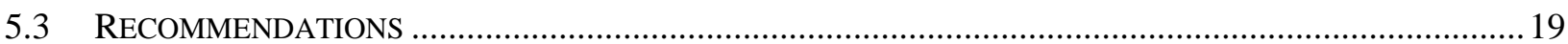

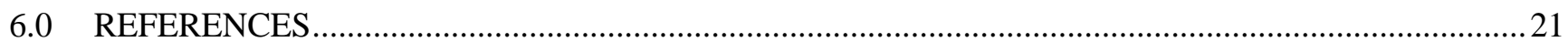

LIBRARY DISTRIBUTION LIST

\section{LIST OF FIGURES}

Figure 1. Corrective ACTION Unit 562 Site LoCATION MAP .2

\section{LIST OF TABLES}

Table 1. Summary of Corrective Action Unit 562 Closure Activities .......................................3

TABle 2. CoRrective Action Unit 562 ClOSURE Activities SCHEdULE .........................................9

Table 3. Corrective Action Unit 562 Waste Disposition Summary ...........................................12

TABle 4. Verification SAMPLE Results FOR CORRECTIVE ACTION Site 02-44-02 ............................15

TABle 5. VerificATION SAMPle Results FOR CORRECTIVE ACTION Site 02-60-03...........................15

TABle 6. VERIFICATION SAMPle RESUltS FOR CORRECTIVE ACTION SiTE 02-60-05 ...........................17

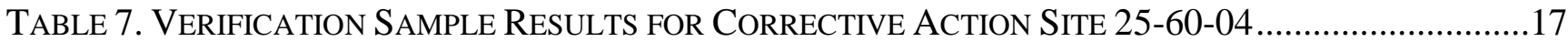

\section{APPENDICES}

ApPEndix A. DATA Quality OBJECTIVES

APPENDiX B. SAMPLE ANALYTICAL RESUlts

APPENDIX C. WASTE DisPOSITION DOCUMENTATION

Appendix D. Site Closure Photographs 


\section{ACRONYMS AND ABBREVIATIONS}

BMP best management practice

CAP Corrective Action Plan

CAS Corrective Action Site

CAU Corrective Action Unit

COC contaminant of concern

CR Closure Report

CSM conceptual site model

DOE U.S. Department of Energy

EPA U.S. Environmental Protection Agency

FFACO Federal Facility Agreement and Consent Order

gal gallon(s)

HW hazardous waste

$\mathrm{mg} / \mathrm{kg} \quad$ milligram(s) per kilogram

NNSA/NSO U.S. Department of Energy, National Nuclear Security Administration Nevada Site Office

NNSA/NV U.S. Department of Energy, National Nuclear Security Administration Nevada Operations Office

NNSS Nevada National Security Site

QA quality assurance

QAPP Industrial Sites Quality Assurance Project Plan

QC quality control

WMA waste management area

$\mathrm{yd}^{3} \quad$ cubic yard(s) 
CAU 562 Closure Report

Section: Acronyms and Abbreviations

Revision: 0

Date: August 2012

THIS PAGE INTENTIONALLY LEFT BLANK 


\section{EXECUTIVE SUMMARY}

This Closure Report (CR) presents information supporting closure of Corrective Action Unit (CAU) 562, Waste Systems, and provides documentation supporting the completed corrective actions and confirmation that closure objectives for CAU 562 were met. This CR complies with the requirements of the Federal Facility Agreement and Consent Order (FFACO) that was agreed to by the State of Nevada; the U.S. Department of Energy (DOE), Environmental Management; the U.S. Department of Defense; and DOE, Legacy Management (FFACO, 1996 as amended). CAU 562 consists of the following 13 Corrective Action Sites (CASs), located in Areas 2, 23, and 25 of the Nevada National Security Site:

- CAS 02-26-11, Lead Shot

- CAS 02-44-02, Paint Spills and French Drain

- CAS 02-59-01, Septic System

- CAS 02-60-01, Concrete Drain

- CAS 02-60-02, French Drain

- CAS 02-60-03, Steam Cleaning Drain

- CAS 02-60-04, French Drain

- CAS 02-60-05, French Drain

- CAS 02-60-06, French Drain

- CAS 02-60-07, French Drain

- CAS 23-60-01, Mud Trap Drain and Outfall

- CAS 23-99-06, Grease Trap

- CAS 25-60-04, Building 3123 Outfalls

Closure activities began in October 2011 and were completed in April 2012. Activities were conducted according to the Corrective Action Plan for CAU 562 (U.S. Department of Energy, National Nuclear Security Administration Nevada Site Office [NNSA/NSO], 2011). The corrective actions included No Further Action and Clean Closure.

Closure activities generated sanitary waste and hazardous waste. Some wastes exceeded land disposal limits and required offsite treatment prior to disposal. Other wastes met land disposal restrictions and were disposed in appropriate onsite or offsite landfills.

NNSA/NSO requests the following:

- A Notice of Completion from the Nevada Division of Environmental Protection to NNSA/NSO for closure of CAU 562

- The transfer of CAU 562 from Appendix III to Appendix IV, Closed Corrective Action Units, of the FFACO 
CAU 562 Closure Report

Section: Executive Summary

Revision: 0

Date: August 2012

\section{THIS PAGE INTENTIONALLY LEFT BLANK}




\subsection{INTRODUCTION}

This Closure Report (CR) documents closure activities for Corrective Action Unit (CAU) 562, Waste Systems, according to the Federal Facility Agreement and Consent Order (FFACO) that was agreed to by the State of Nevada; the U.S. Department of Energy (DOE), Environmental Management; the U.S. Department of Defense; and DOE, Legacy Management (FFACO, 1996 as amended). CAU 562 consists of the following 13 Corrective Action Sites (CASs), located in Areas 2, 23, and 25 of the Nevada National Security Site (NNSS) (Figure 1):

- CAS 02-26-11, Lead Shot

- CAS 02-44-02, Paint Spills and French Drain

- CAS 02-59-01, Septic System

- CAS 02-60-01, Concrete Drain

- CAS 02-60-02, French Drain

- CAS 02-60-03, Steam Cleaning Drain

- CAS 02-60-04, French Drain

- CAS 02-60-05, French Drain

- CAS 02-60-06, French Drain

- CAS 02-60-07, French Drain

- CAS 23-60-01, Mud Trap Drain and Outfall

- CAS 23-99-06, Grease Trap

- CAS 25-60-04, Building 3123 Outfalls

\subsection{Purpose}

This CR provides justification for closure of CAU 562 without further corrective action based on implementation of corrective actions in accordance with the Corrective Action Plan (CAP) for CAU 562 (U.S. Department of Energy, National Nuclear Security Administration Nevada Site Office [NNSA/NSO], 2011). This CR provides a summary of completed closure activities, documentation supporting the completed corrective actions, and confirmation that the closure objectives were met.

\subsection{SCOPE}

The scope of closure for CAU 562 included No Further Action and Clean Closure. Completed closure activities are summarized in Table 1. 


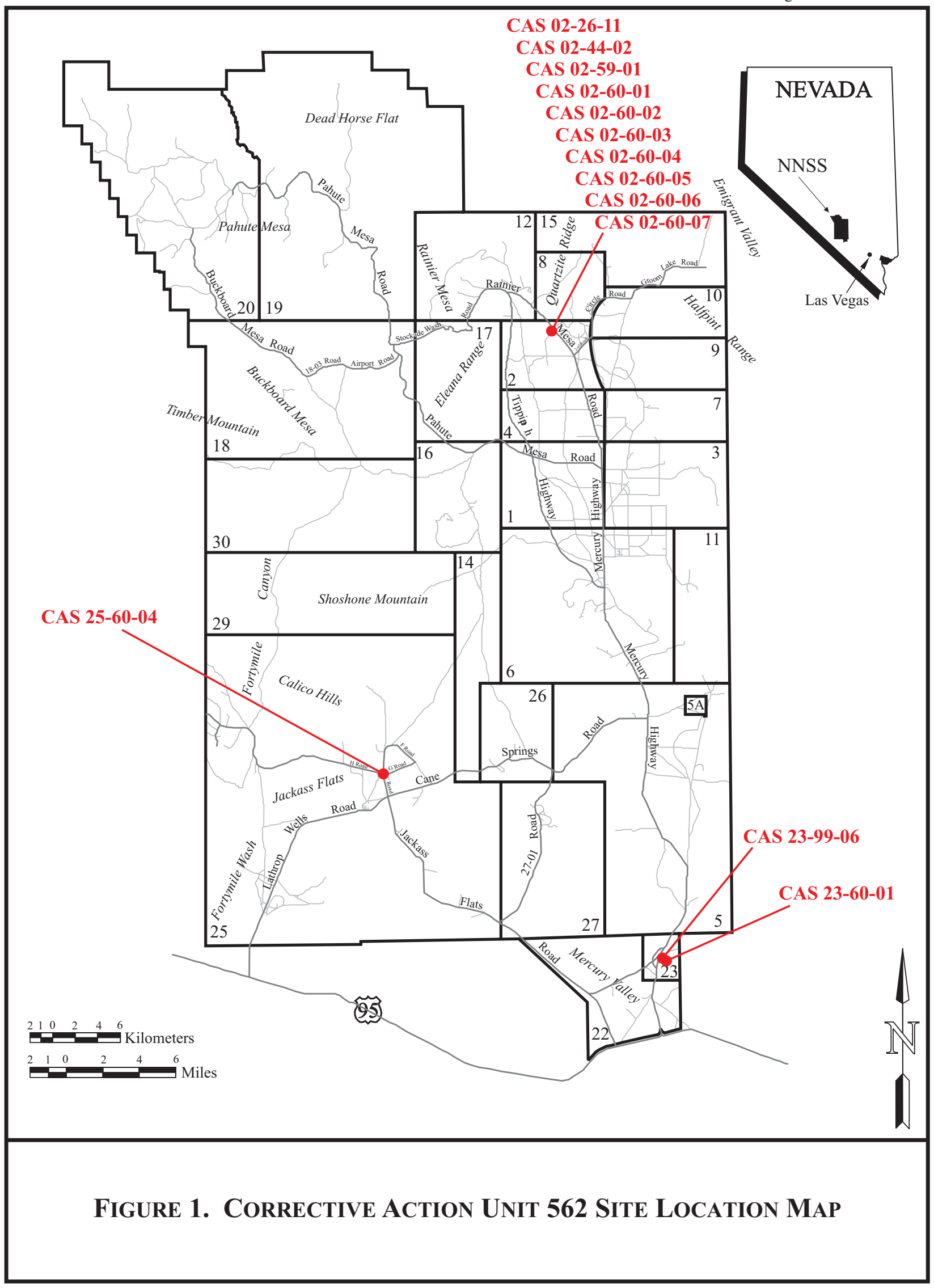


TABle 1. Summary of Corrective ACTION Unit 562 Closure Activities

\begin{tabular}{|c|c|c|c|}
\hline CAS & CAS NAME & CLOSURE METHOD & Closure ACtivities \\
\hline 02-26-11 & Lead Shot & Clean Closure & $\begin{array}{l}\text { - Lead and steel shot and associated soil were removed, packaged in ten 55-gal drums and two } \\
\text { roll-off containers, and treated and disposed as HW at an offsite facility. }\end{array}$ \\
\hline 02-44-02 & $\begin{array}{l}\text { Paint Spills and } \\
\text { French Drain }\end{array}$ & Clean Closure & $\begin{array}{l}\text { - Dried paint was removed from concrete foundations, packaged in three 55-gal drums and one } \\
\text { 10-gal bucket, and treated and disposed as HW at an offsite facility. } \\
\text { - A paint rack, a large vent pipe, and a railing from a small building were removed, packaged in a } \\
\text { roll-off container, and treated and disposed as HW at an offsite facility. } \\
\text { - Soil impacted with benzo(a)pyrene was removed and disposed at the Area } 9 \text { U10c Sanitary } \\
\text { Landfill. Verification samples were collected, and the excavation was backfilled. } \\
\text { - Asbestos tile was picked up from around the site and disposed at the Area } 9 \text { U10c Sanitary } \\
\text { Landfill. } \\
\text { - A small building was demolished and disposed at the Area } 9 \text { U10c Sanitary Landfill. }\end{array}$ \\
\hline 02-59-01 & Septic System & Clean Closure & $\begin{array}{l}\text { - Liquid was removed from a septic tank and disposed at the Area } 23 \text { Sewage Lagoons. } \\
\text { - Sludge was removed from a septic tank and disposed at the Area } 6 \text { Hydrocarbon Landfill. } \\
\text { - The septic tank and two distribution boxes were removed and disposed at the Area } 9 \text { U10c } \\
\text { Sanitary Landfill, and the excavation was backfilled. }\end{array}$ \\
\hline 02-60-01 & Concrete Drain & No Further Action & - A concrete drain was removed and disposed at the Area 9 U10c Sanitary Landfill. \\
\hline 02-60-02 & French Drain & Clean Closure & - Drain grates and a drain pipe were removed and disposed at the Area 9 U10c Sanitary Landfill. \\
\hline 02-60-03 & $\begin{array}{l}\text { Steam Cleaning } \\
\text { Drain }\end{array}$ & Clean Closure & $\begin{array}{l}\text { - Soil impacted with benzo(a)pyrene was removed and disposed at the Area 9 U10c Sanitary } \\
\text { Landfill. Verification samples were collected, and the excavation was backfilled. } \\
\text { - Soil impacted with Aroclor } 1260 \text { was removed and disposed at the Area } 9 \text { U10c Sanitary Landfill. } \\
\text { Verification samples were collected, and the excavation was backfilled. } \\
\text { - A sump grate and outfall pipe were removed and disposed at the Area } 9 \text { U10c Sanitary Landfill. }\end{array}$ \\
\hline 02-60-04 & French Drain & Clean Closure & - Corrective actions were completed during corrective action investigation activities. \\
\hline 02-60-05 & French Drain & Clean Closure & $\begin{array}{l}\text { - Soil impacted with semi-volatile organic compounds was removed and disposed at the Area } 9 \\
\text { U10c Sanitary Landfill. Verification samples were collected, and the excavation was backfilled. }\end{array}$ \\
\hline $02-60-06$ & French Drain & No Further Action & - No corrective actions were required. \\
\hline 02-60-07 & French Drain & No Further Action & - No corrective actions were required. \\
\hline
\end{tabular}


TABle 1. Summary OF CoRrective ACTION Unit 562 Closure Activities (Continued)

\begin{tabular}{|c|c|c|c|}
\hline CAS & CAS NAME & Closure Method & Closure ACtivities \\
\hline 23-60-01 & $\begin{array}{l}\text { Mud Trap Drain } \\
\text { and Outfall }\end{array}$ & Clean Closure & $\begin{array}{l}\text { - Sediment was removed from a mud trap and disposed at the Area } 9 \text { U10c Sanitary Landfill. } \\
\text { - The mud trap and outfall pipe were removed and disposed at the Area } 9 \text { U10c Sanitary Landfill, } \\
\text { and the excavation was backfilled. }\end{array}$ \\
\hline 23-99-06 & Grease Trap & Clean Closure & $\begin{array}{l}\text { - Sediment was removed from a grease trap and disposed at the Area } 9 \text { U10c Sanitary Landfill. The } \\
\text { grease trap was backfilled. }\end{array}$ \\
\hline $25-60-04$ & $\begin{array}{l}\text { Building } 3123 \\
\quad \text { Outfalls }\end{array}$ & Clean Closure & $\begin{array}{l}\text { - An outfall pipe and sludge impacted with lead and Aroclor } 1254 \text { was removed and disposed at the } \\
\text { Area } 9 \text { U10c Sanitary Landfill. } \\
\text { - Soil impacted with Aroclor } 1254 \text { was removed and disposed at the Area } 9 \text { U10c Sanitary Landfill. } \\
\text { Verification samples were collected, and the excavation was backfilled. }\end{array}$ \\
\hline
\end{tabular}

CAS: Corrective Action Site

gal: gallon(s)

HW: hazardous waste 


\subsection{Closure Report Contents}

This CR includes the following sections:

- Section 1.0: Introduction

- Section 2.0: Closure Activities

- Section 3.0: Waste Disposition

- Section 4.0: Closure Verification Results

- Section 5.0: Conclusions and Recommendations

- Section 6.0: References

- Appendix A: Data Quality Objectives

- Appendix B: Sample Analytical Results

- Appendix C: Waste Disposition Documentation

- Appendix D: Site Closure Photographs

- Library Distribution List

\subsubsection{Applicable Programmatic Plans and Documents}

Closure activities were performed in accordance with the following documents:

- CAP for CAU 562 (NNSA/NSO, 2011)

- $\quad$ FFACO (1996, as amended)

\subsubsection{Data Quality Objectives}

Data quality objectives were developed for CAU 562 in the Corrective Action Investigation Plan (NNSA/NSO, 2009) and are included as Appendix A of this report. Conceptual site models (CSMs) were developed based on process knowledge, historical information, and personnel interviews. With the exception of CAS 02-60-05, no variations to the CSMs were identified, and the CSMs were confirmed by soil sample results and verified during closure activities. Section 4.1.3 describes the variation to the CSM at CAS 02-60-05.

\subsubsection{Data Quality Assessment}

The data quality assessment presented in Section 4.1 describes the quality assurance (QA) and quality control (QC) procedures and the data validation process. Accurate and defensible analytical data were collected and verify that the closure objectives were met. 
CAU 562 Closure Report

Section: Introduction

Revision: 0

Date: August 2012

THIS PAGE INTENTIONALLY LEFT BLANK 


\subsection{CLOSURE ACTIVITIES}

This section includes a description of the closure activities performed for CAU 562, deviations from the CAP, and schedule of completed field work.

\subsection{Description of CoRrective ACTIOn ACTIVITIES}

The following sections describe the closure activities completed for each CAS in CAU 562.

\subsubsection{Corrective Action Site 02-26-11, Lead Shot}

This site was clean closed by removing approximately 20 cubic yards ( $\left.\mathrm{yd}^{3}\right)$ lead and steel shot and associated soil. The waste was packaged in ten 55-gallon (gal) drums and two roll-off containers and treated and disposed as hazardous waste (HW) at an offsite facility.

\subsubsection{Corrective Action Site 02-44-02, Paint Spills and French Drain}

This site was clean closed. Dried paint was removed from concrete foundations, packaged in three 55-gal drums and one 5-gal bucket, and treated and disposed as HW at an offsite facility. A paint rack, a large vent pipe, and a railing from a small building were removed, packaged in a roll-off container, and treated and disposed as HW at an offsite facility. The underground pipe remaining after removal of the aboveground portion of the vent pipe was grouted to grade. Approximately $5 \mathrm{yd}^{3}$ of soil impacted with benzo(a)pyrene were removed and disposed. Waste characterization results confirmed the soil could be disposed at the Area 9 U10c Sanitary Landfill. Verification samples were collected, and the excavation was backfilled. Asbestos tile was picked up from around the site, packaged in 55-gal drums, and disposed the Area 9 U10c Sanitary Landfill. A small building was demolished and disposed at the Area 9 U10c Sanitary Landfill.

\subsubsection{Corrective Action Site 02-59-01, Septic System}

This site was clean closed. Approximately 4,500 gal of liquid were removed from the septic tank and disposed at the Area 23 Sewage Lagoons. Approximately 800 gal of sludge were removed from the septic tank, solidified, and disposed at the Area 6 Hydrocarbon Landfill. The septic tank and two distribution boxes were removed and disposed at the Area 9 U10c Sanitary Landfill, and the excavation was backfilled.

\subsubsection{Corrective Action Site 02-60-01, Concrete Drain}

No contaminants of concern (COCs) were present at concentrations above action levels at this site, and no further action was required. As a best management practice (BMP), the concrete drain was removed and disposed at the Area 9 U10c Sanitary Landfill.

\subsubsection{Corrective Action Site 02-60-02, French Drain}

This site was clean closed. Corrective actions were completed during corrective action investigation activities. As a BMP, drain grates and a drain pipe were removed and disposed at the Area 9 U10c Sanitary Landfill. 


\subsubsection{Corrective Action Site 02-60-03, Steam Cleaning Drain}

This site was clean closed. Approximately $15 \mathrm{yd}^{3}$ of soil impacted with benzo(a)pyrene were removed and disposed at the Area 9 U10c Sanitary Landfill. Verification samples were collected, and the excavation was backfilled. Approximately $10 \mathrm{yd}^{3}$ of soil impacted with Aroclor 1260 were removed and disposed. Waste characterization results confirmed the soil could be disposed at the Area 9 U10c Sanitary Landfill. Verification samples were collected, and the excavation was backfilled. The steam cleaning sump grate and outfall pipe were removed and disposed at the Area 9 U10c Sanitary Landfill.

\subsubsection{Corrective Action Site 02-60-04, French Drain}

This site was clean closed. Corrective actions were completed during corrective action investigation activities.

\subsubsection{Corrective Action Site 02-60-05, French Drain}

This site was clean closed. Approximately $90 \mathrm{yd}^{3}$ of soil impacted with semi-volatile organic compounds were removed and disposed at the Area 9 U10c Sanitary Landfill. Verification samples were collected, and the excavation was backfilled.

\subsubsection{Corrective Action Site 02-60-06, French Drain}

No COCs were present at concentrations above action levels at this site, and no corrective actions were required.

\subsubsection{Corrective Action Site 02-60-07, French Drain}

No COCs were present at concentrations above action levels at this site, and no corrective actions were required.

\subsubsection{Corrective Action Site 23-60-01, Mud Trap Drain and Outfall}

This site was clean closed. Approximately $5 \mathrm{yd}^{3}$ of sediment were removed from the mud trap and disposed. Waste characterization results confirmed the sediment could be disposed at the Area 9 U10c Sanitary Landfill. The mud trap and outfall pipe were removed and disposed at the Area 9 U10c Sanitary Landfill, and the excavation was backfilled.

\subsubsection{Corrective Action Site 23-99-06, Grease Trap}

This site was clean closed. Approximately $0.5 \mathrm{yd}^{3}$ of sediment were removed from the grease trap, packaged in 55-gal drums, and disposed at the Area 9 U10c Sanitary Landfill. The grease trap was backfilled.

\subsubsection{Corrective Action Site 25-60-04, Building 3123 Outfalls}

This site was clean closed. The outfall pipe and a small volume of sludge impacted with lead and Aroclor 1254 were removed and disposed. Waste characterization results confirmed the sludge could be disposed at the Area 9 U10c Sanitary Landfill. Approximately $71 \mathrm{yd}^{3}$ of soil impacted with Aroclor 1254 were removed and disposed at the Area 9 U10c Sanitary Landfill. Verification samples were collected, and the excavation was backfilled. 


\subsection{Deviations from the Plan as Approved}

Deviations from the CAP for CAU 562 (NNSA/NSO, 2011) were not required.

\subsection{Corrective ACtion Schedule as COMPLETED}

Closure activities began in October 2011 and were completed in April 2012. Details of the schedule are provided in the table below. Waste disposal took place after the end dates listed below in some cases.

TABle 2. Corrective Action Unit 562 Closure Activities Schedule

\begin{tabular}{||l|l|l||}
\hline \multicolumn{1}{|c|}{ CORRECTIVE ACTION SITE } & \multicolumn{1}{c|}{ START } & \multicolumn{1}{c|}{ END } \\
\hline \hline 02-26-11, Lead Shot & $10 / 26 / 2011$ & $01 / 19 / 2012$ \\
\hline 02-44-02, Paint Spills and French Drain & $11 / 01 / 2011$ & $01 / 17 / 2012$ \\
\hline 02-59-01, Septic System & $11 / 15 / 2011$ & $01 / 17 / 2012$ \\
\hline 02-60-01, Concrete Drain & $12 / 15 / 2011$ & $12 / 15 / 2011$ \\
\hline 02-60-02, French Drain & $12 / 14 / 2011$ & $12 / 14 / 2011$ \\
\hline 02-60-03, Steam Cleaning Drain & $12 / 14 / 2011$ & $04 / 02 / 2012$ \\
\hline 02-60-05, French Drain & $12 / 14 / 2011$ & $04 / 02 / 2012$ \\
\hline 23-60-01, Mud Trap Drain and Outfall & $01 / 19 / 2012$ & $01 / 26 / 2012$ \\
\hline 23-99-06, Grease Trap & $01 / 19 / 2012$ & $01 / 19 / 2012$ \\
\hline 25-60-04, Building 3123 Outfalls & $01 / 23 / 2012$ & $03 / 20 / 2012$ \\
\hline \hline
\end{tabular}

\subsection{Site Plan/Survey Plat}

As-built drawings were not required for CAU 562 closure activities. 
Revision: 0

Date: August 2012

\section{THIS PAGE INTENTIONALLY LEFT BLANK}




\subsection{WASTE DISPOSITION}

This section describes the waste generated during closure activities and its final disposition.

\subsection{WASTE MinimizATion}

Waste minimization practices applied throughout closure activities included the following:

- Radiological surveys to verify acceptance of debris at the Area 9 U10c Sanitary Landfill

- Laboratory analysis to correctly characterize and segregate waste streams

- $\quad$ Size reduction of debris

\subsection{WASTE MANAGEMENT}

Waste was characterized and managed according to federal and state regulations, DOE orders, and NSTec procedures. Waste management areas (WMAs) were established as needed and identified with appropriate signs and boundaries to restrict unauthorized access. WMAs were inspected on a weekly or monthly basis, as required, to ensure that containers were intact, not leaking, and not exceeding storage duration times. Waste containers were purchased either new or reconditioned. Containers were inspected prior to use to verify that they were in good condition (e.g., no leaks, rust, or dents), lined or made of material that would not react with the waste, and met U.S. Department of Transportation requirements. Containers remained closed while stored unless waste was being added or removed. Containers were handled in such a manner that the integrity of the container was not compromised. Appropriate labels were affixed, and relevant information was marked on the containers with an indelible marker. Information was legible and clearly visible.

\subsection{WASTE DisPOSAL}

Waste disposition is summarized in Table 3 and discussed in the following sections. Waste disposition documentation is included in Appendix C.

\subsubsection{Sanitary Waste}

Approximately $320 \mathrm{yd}^{3}$ of sanitary waste were generated during closure activities. Sanitary waste included soil from CAS 02-44-02, CAS 02-60-03, CAS 02-60-05, and CAS 25-60-04; asbestos tile from CAS 02-44-02; a small building from CAS 02-44-02; sludge and a septic tank from CAS 02-59-01; drains, grates, and pipes from CAS 02-60-01, CAS 02-60-02, CAS 02-60-03, CAS 23-60-01, and CAS 25-60-04; and sediment/sludge from CAS 23-60-01 and CAS 23-99-06. In addition, approximately 4,500 gal of liquid from the septic tank at CAS 02-59-01 were disposed at the Area 23 Sewage Lagoons.

\subsubsection{Hazardous Waste}

Approximately $64 \mathrm{yd}^{3}$ of HW were generated during closure activities and transported to U.S. Ecology in Beatty, Nevada, for treatment and disposal. HW included lead and steel shot and associated soil from CAS 02-26-11, paint from CAS 02-44-02, and debris from CAS 02-44-02. 
TABle 3. CoRrective Action Unit 562 WASTE Disposition SuMMARY

\begin{tabular}{|c|c|c|c|c|c|c|}
\hline $\begin{array}{l}\text { WASTE } \\
\text { STREAM }\end{array}$ & DESCRIPTION OF WASTE & VOLUME & WASTE CONTAINER & $\begin{array}{c}\text { DATE OF } \\
\text { DISPOSAL }\end{array}$ & $\begin{array}{c}\text { DISPOSITION } \\
\text { DOCUMENTATION }\end{array}$ & DISPOSAL FACILITY \\
\hline \multirow{17}{*}{$\begin{array}{l}\text { Sanitary } \\
\text { Waste }\end{array}$} & Housekeeping debris from Area 2 & $2 \mathrm{yd}^{3}$ & U Unpackaged & $12 / 15 / 2011$ & \multirow{15}{*}{$\begin{array}{l}\text { Landfill Load } \\
\text { Verification Forms }\end{array}$} & \multirow{15}{*}{ Area 9 U10c Sanitary Landfill } \\
\hline & CAS 02-44-02 soil & $5 \mathrm{yd}^{3}$ & Unpackaged & $12 / 15 / 2011$ & & \\
\hline & CAS 02-44-02 asbestos tile & $1.5 \mathrm{yd}^{3}$ & Five 55-gal drums & 03/08/2012 & & \\
\hline & CAS 02-44-02 building & $15 \mathrm{yd}^{3}$ & Unpackaged & $01 / 12 / 2012$ & & \\
\hline & CAS 02-59-01 septic tank & $26 \mathrm{yd}^{3}$ & Unpackaged & $12 / 08 / 2011$ & & \\
\hline & CAS 02-59-01 distribution boxes & $30 \mathrm{yd}^{3}$ & Unpackaged & $01 / 17 / 2012$ & & \\
\hline & CAS 02-60-01 concrete drain & $1 \mathrm{yd}^{3}$ & Unpackaged & $12 / 15 / 2011$ & & \\
\hline & CAS 02-60-02 drain grates and drain pipe & $1 \mathrm{yd}^{3}$ & Unpackaged & $12 / 15 / 2011$ & & \\
\hline & CAS 02-60-03 soil & $25 \mathrm{yd}^{3}$ & Unpackaged & $12 / 15 / 2011$ & & \\
\hline & CAS 02-60-03 sump grate and outfall pipe & $1 \mathrm{yd}^{3}$ & Unpackaged & $12 / 15 / 2011$ & & \\
\hline & CAS 02-60-05 soil & $90 \mathrm{yd}^{3}$ & Unpackaged & $\begin{array}{l}12 / 15 / 2011 \\
01 / 12 / 2012\end{array}$ & & \\
\hline & CAS 23-60-01 mud trap & $10 \mathrm{yd}^{3}$ & Unpackaged & $01 / 26 / 2012$ & & \\
\hline & CAS 23-60-01 sediment and outfall pipe & $8 \mathrm{yd}^{3}$ & Unpackaged & $01 / 19 / 2012$ & & \\
\hline & CAS 23-99-06 sediment & $0.5 \mathrm{yd}^{3}$ & Two 55-gal drums & 03/06/2012 & & \\
\hline & CAS 25-60-04 outfall pipe, sludge, and soil & $71 \mathrm{yd}^{3}$ & Unpackaged & $\begin{array}{l}01 / 24 / 2012 \\
02 / 29 / 2012 \\
03 / 12 / 2012\end{array}$ & & \\
\hline & CAS 02-59-01 solidified sludge & $32 \mathrm{yd}^{3}$ & Unpackaged & $\begin{array}{l}12 / 08 / 2011 \\
12 / 13 / 2011\end{array}$ & $\begin{array}{l}\text { Landfill Load } \\
\text { Verification Forms }\end{array}$ & Area 6 Hydrocarbon Landfill \\
\hline & CAS 02-59-01 liquid & 4,500 gal & Unpackaged & $\begin{array}{l}11 / 15 / 2011 \\
11 / 17 / 2011\end{array}$ & None & Area 23 Sewage Lagoons \\
\hline
\end{tabular}


Date: August 2012

TABle 3. CoRrective ACTION UNIT 562 WASTE Disposition SUMMARY (CONTINUED)

\begin{tabular}{|c|c|c|c|c|c|c|}
\hline $\begin{array}{l}\text { WASTE } \\
\text { STREAM }\end{array}$ & DESCRIPTION OF WASTE & VOLUME & WASTE CONTAINER & $\begin{array}{l}\text { DATE OF } \\
\text { DISPOSAL }\end{array}$ & $\begin{array}{c}\text { DISPOSITION } \\
\text { DOCUMENTATION }\end{array}$ & DISPOSAL FACILITY \\
\hline \multirow{3}{*}{ HW } & CAS 02-26-11 lead and steel shot and associated soil & $43 \mathrm{yd}^{3}$ & $\begin{array}{l}\text { Ten 55-gal drums and } \\
\text { two roll-off containers }\end{array}$ & $\begin{array}{l}01 / 17 / 2012 \\
02 / 08 / 2012\end{array}$ & \multirow{3}{*}{$\begin{array}{l}\text { Uniform HW } \\
\text { Manifest }\end{array}$} & \multirow{3}{*}{$\begin{array}{l}\text { U.S. Ecology in Beatty, } \\
\text { Nevada }\end{array}$} \\
\hline & CAS 02-44-02 dried paint & 170 gal & $\begin{array}{l}\text { One 5-gal bucket and } \\
\text { three 55-gal drums }\end{array}$ & 06/07/2012 & & \\
\hline & CAS 02-44-02 paint rack, vent pipe, and railing & $20 \mathrm{yd}^{3}$ & One roll-off container & $01 / 12 / 2012$ & & \\
\hline
\end{tabular}

CAS: Corrective Action Site

gal: gallon(s)

HW: hazardous waste

$\mathrm{yd}^{3}$ : cubic yard(s) 
Revision: 0

Date: August 2012

THIS PAGE INTENTIONALLY LEFT BLANK 


\subsection{CLOSURE VERIFICATION RESULTS}

Site closure was verified by visual inspection and photographic documentation of final site conditions. Photographs are included in Appendix D. In addition, soil verification samples were collected from the excavations at CAS 02-44-02, CAS 02-60-03, CAS 02-60-05, and CAS 25-60-04. With the exception of CAS 02-60-05, results verified that remaining soil does not contain contamination above action levels. Sample results are summarized in the following sections, and the laboratory summary data reports are included in Appendix B.

\subsection{VERIFICATION SAMPLE RESULTS}

\subsubsection{Corrective Action Site 02-44-02, Paint Spills and French Drain}

At CAS 02-44-02, soil impacted with benzo(a)pyrene was removed and disposed. Two verification samples were collected from the excavation and analyzed for benzo(a)pyrene. Benzo(a)pyrene was not detected in the samples at concentrations above the action level. The results are listed in Table 4.

TABle 4. Verification SAMPle Results for CoRrective Action Site 02-44-02

\begin{tabular}{||c|c|c|c||}
\hline \multirow{2}{*}{ ANALYTE } & \multirow{2}{*}{$\begin{array}{c}\text { ACTION LEVEL } \\
(\mathrm{mg} / \mathrm{kg})\end{array}$} & $\mathbf{0 2 4 4 0 2 - V 1}$ & $\mathbf{0 2 4 4 0 2 - V 2}$ \\
\cline { 3 - 4 } & 0.21 & $0.0524^{*}$ & $0.104^{*}$ \\
\hline \hline Benzo(a)pyrene & &
\end{tabular}

mg/kg: milligram(s) per kilogram

* Analyte was not detected at a concentration above the reporting limit. Result reported is equal to the reporting limit.

\subsubsection{Corrective Action Site 02-60-03, Steam Cleaning Drain}

At CAS 02-60-03, soil impacted with benzo(a)pyrene was removed and disposed. Two verification samples were collected from the excavation and analyzed for benzo(a)pyrene. Benzo(a)pyrene was not detected in the samples at concentrations above the action level. The results are listed in Table 5. Soil impacted with Aroclor 1260 was removed and disposed. Two verification samples were collected from the excavation and analyzed for Aroclor 1260 . Aroclor 1260 was not detected in the samples at concentrations above the action level. The results are listed in Table 5.

TABLe 5. Verification SAMPle Results for CoRRective ACTION Site 02-60-03

\begin{tabular}{||c|c|c|c|c|c||}
\hline \multirow{2}{*}{ ANALYTE } & \multirow{2}{*}{$\begin{array}{c}\text { ACTION LEVEL } \\
(\mathrm{mg} / \mathrm{kg})\end{array}$} & $\mathbf{0 2 6 0 0 3 - V 1}$ & $\mathbf{0 2 6 0 0 3 - V 2}$ & $\mathbf{0 2 6 0 0 3 - V 3}$ & $\mathbf{0 2 6 0 0 3 - V 4}$ \\
\cline { 3 - 6 } & 0.21 & 0.131 & 0.174 & NA & NA \\
\hline \hline Benzo(a)pyrene & 0.74 & NA & NA & $0.0141^{*}$ & $0.0709 *$ \\
\hline Aroclor 1260 & & &
\end{tabular}

mg/kg: milligram(s) per kilogram

NA: not analyzed

*Analyte was not detected at a concentration above the reporting limit. Result reported is equal to the reporting limit. 


\subsubsection{Corrective Action Site 02-60-05, French Drain}

At CAS 02-60-05, soil impacted with semi-volatile organic compounds was removed and disposed. Five verification samples were collected from the excavation and analyzed for semi-volatile organic compounds. Sample 026005-V4, which was collected from the bottom of the excavation, was above the action levels for benzo(a)pyrene and dibenz(a,h)anthracene, so additional soil was removed from the bottom of the excavation. Three additional verification samples were collected from the excavation after the second round of soil removal. Sample 026005-V8, which was collected from the bottom of the excavation at approximately 17 feet below ground surface, was above the action level for benzo(a)pyrene. The results are listed in Table 6.

This finding is not consistent with the CSM for CAS 02-60-05 due to the location of the release and the chemical properties of benzo(a)pyrene. It is not reasonable that benzo(a)pyrene could have migrated through the soil to this depth given that benzo(a)pyrene has very low solubility in water and very low mobility in soil, and there has been no infiltration of water at this location other than the low natural infiltration rate of precipitation. It is believed that the benzo(a)pyrene found in the sample at the bottom of the excavation has not migrated through the soil but is the result of contaminated surface soil that has fallen into the excavation from the operation of the backhoe.

The corrective action investigation results for benzo(a)pyrene were above the action level in surface soils at all locations in the area of this CAS. Concentrations ranged from 0.36 to $37 \mathrm{mg} / \mathrm{kg}$. Therefore, benzo(a)pyrene is ubiquitous in the surface soils at this CAS. During the corrective action investigation, layers of chip seal were identified throughout the area at a thickness of up to 1 inch. The Corrective Action Decision Document concluded that much of the semi-volatile organic compound contamination in surface soils was due to the "presence of the asphalt-like chip seal and are not considered contaminants of concern” (NNSA/NSO, 2010).

A track excavator with a large bucket was required to complete the required depth of the excavation. Due to loose material at the surface, it was difficult to keep material from the surface around the excavation from sloughing into the bottom of the excavation. The depth and steep sides of the excavation precluded placing anyone in the excavation to collect a sample; therefore, verification samples were collected from the excavator bucket. The size of the excavator bucket made it difficult to identify sloughed material from material originating from the bottom of the excavation.

The premise that the benzo(a)pyrene concentrations in the verification samples are from sloughed material is further substantiated by additional evidence. Samples collected from the sides of the excavation were below the action level while samples collected from the bottom of the excavation contained fairly consistent concentrations of benzo(a)pyrene. A very small amount of sloughed surface soil in an otherwise clean soil sample could result in the low concentrations of benzo(a)pyrene in the samples collected from the bottom of the excavation.

Therefore, it is believed that the benzo(a)pyrene found in samples from the bottom of the excavation is due to cross-contamination from the surface soil. Also, there are no potential receptors that could reasonably be exposed to soil from this depth. Considering these factors, it is proposed to close the site without further excavation and without a use restriction. 
TABle 6. Verification SAMPle Results for CoRrective ACtion Site 02-60-05

\begin{tabular}{|c|c|c|c|c|c|c|c|c|c|}
\hline \multirow[b]{2}{*}{ ANALYTE } & \multirow{2}{*}{$\begin{array}{c}\text { ACTION } \\
\text { LEVEL } \\
\text { (mg/kg) }\end{array}$} & \multicolumn{8}{|c|}{ SAMPLE RESULTS (mg/kg) } \\
\hline & & $\begin{array}{c}\text { 026005- } \\
\text { V1 }\end{array}$ & $\begin{array}{l}\text { 026005- } \\
\text { V2 }\end{array}$ & $\begin{array}{c}\text { 026005- } \\
\text { V3 }\end{array}$ & $\begin{array}{c}\text { 026005- } \\
\text { V4 }\end{array}$ & $\begin{array}{l}\text { 026005- } \\
\text { V5 }\end{array}$ & $\begin{array}{c}\text { 026005- } \\
\text { V6 }\end{array}$ & $\begin{array}{c}\text { 026005- } \\
\text { V7 }\end{array}$ & $\begin{array}{c}\text { 026005- } \\
\text { V8 }\end{array}$ \\
\hline Pyrene & $17,17,000$ & $0.0539 *$ & $0.0539 *$ & $0.0543^{*}$ & 0.691 & $0.0514^{*}$ & NA & "NA & NA \\
\hline $\begin{array}{c}\text { Benz(a) } \\
\text { anthracene }\end{array}$ & 2.1 & $0.0539 *$ & $0.0539 *$ & $0.0543 *$ & $0.413^{*}$ & $0.0514 *$ & NA & NA & NA \\
\hline $\begin{array}{l}\text { Benzo(b) } \\
\text { flouranthene }\end{array}$ & 2.1 & $0.0539 *$ & $0.0539 *$ & $0.0543 *$ & $0.413 *$ & $0.0514^{*}$ & NA & NA & NA \\
\hline $\begin{array}{c}\text { Benzo(k) } \\
\text { flouranthene }\end{array}$ & 21 & $0.0539 *$ & $0.0539 *$ & $0.0543 *$ & $0.413^{*}$ & $0.0514^{*}$ & NA & NA & NA \\
\hline Benzo(a)pyrene & 0.21 & $0.0539 *$ & $0.0539 *$ & $0.0543^{*}$ & 0.593 & $0.0514^{*}$ & $0.0109 *$ & $0.0106 *$ & 0.548 \\
\hline $\begin{array}{c}\text { Indeno(1,2,3-cd) } \\
\text { pyrene }\end{array}$ & 2.1 & 0.0539* & $0.0539 *$ & $0.0543 *$ & $0.413^{*}$ & $0.0514 *$ & NA & NA & NA \\
\hline $\begin{array}{c}\text { Dibenz(a,h) } \\
\text { anthracene }\end{array}$ & 0.21 & $0.0539 *$ & $0.0539 *$ & $0.0543 *$ & $0.413 *$ & $0.0514^{*}$ & $0.0109 *$ & $0.0106 *$ & 0.162 \\
\hline
\end{tabular}

mg/kg: milligram(s) per kilogram

NA: not analyzed

*Analyte was not detected at a concentration above the reporting limit. Result reported is equal to the reporting limit.

NOTE: Results greater than the action level are identified by bold text.

\subsubsection{Corrective Action Site 25-60-04, Building 3123 Outfalls}

At CAS 25-60-04, soil impacted with Aroclor 1254 was removed and disposed. Three verification samples were collected from the excavation and analyzed for Aroclor 1254. Sample 25-60-04-V1 was collected from the western sidewall of the excavation, and Aroclor 1254 was not detected at concentrations above the action level. Samples 25-60-04-V2 and 25-60-04-V3 were collected from the bottom and eastern sidewall of the excavation, respectively. These samples were above the action level, so additional soil was removed from the bottom of the excavation, and the excavation was expanded to the east. Three additional verification samples were collected from the excavation after the second round of soil removal. Aroclor 1254 was not detected in the samples at concentrations above the action level. The results are listed in Table 7.

TABle 7. Verification SAMPle Results for CoRrective ACtion Site 25-60-04

\begin{tabular}{||c|c|c|c|c|c|c|c||}
\hline \multirow{3}{*}{ ANALYTE } & \multirow{2}{*}{$\begin{array}{c}\text { ACTION } \\
\text { LEVEL }\end{array}$} & \multicolumn{6}{|c||}{ SAMPLE RESULTS (mg/kg) } \\
\cline { 3 - 8 } & $(\mathrm{mg} / \mathrm{kg})$ & $\begin{array}{c}\mathbf{2 5 - 6 0 - 0 4 -} \\
\text { V1 }\end{array}$ & $\begin{array}{c}\mathbf{2 5 - 6 0 - 0 4 -} \\
\text { V2 }\end{array}$ & $\begin{array}{c}\mathbf{2 5 - 6 0 - 0 4 -} \\
\text { V3 }\end{array}$ & $\begin{array}{c}\mathbf{2 5 - 6 0 - 0 4 -} \\
\text { V4 }\end{array}$ & $\begin{array}{c}\mathbf{2 5 - 6 0 - 0 4 -} \\
\text { V5 }\end{array}$ & $\begin{array}{c}\text { 25-60-04- } \\
\text { V6 }\end{array}$ \\
\hline \hline Aroclor 1254 & 0.74 & 0.0735 & $\mathbf{3 . 0 3}$ & $\mathbf{0 . 7 5 9}$ & 0.02 & $0.0135^{*}$ & $0.014^{*}$ \\
\hline \hline
\end{tabular}

mg/kg: milligram(s) per kilogram

*Analyte was not detected at a concentration above the reporting limit. Result reported is equal to the reporting limit.

NOTE: Results greater than the action level are identified by bold text. 


\subsection{Data Quality Assessment}

Accurate and defensible analytical data were collected to verify that the closure objectives were met. Analytical data results are included as Appendix B. The following sections describe the QA/QC procedures and the data validation process. More detail on the QA/QC procedures can be found in the Industrial Sites Quality Assurance Project Plan (QAPP) (U.S. Department of Energy, National Nuclear Security Administration Nevada Operations Office [NNSA/NV], 2002).

\subsubsection{Quality Assurance and Quality Control Procedures}

Verification samples were collected with disposable sampling equipment, placed in appropriately labeled containers secured with custody seals, labeled with unique sample numbers, placed on ice, and transported under strict chain of custody. Standard QA/QC samples were collected (i.e., one blind duplicate per batch). Samples were analyzed by certified contract laboratories. Analytical results were validated at the laboratory using stringent QA/QC procedures, including matrix spike/matrix spike duplicates, spiked surrogate recovery analysis, verification of analytical results, and data quality indicator requirements.

\subsubsection{Data Validation}

Data validation was performed according to the QAPP (NNSA/NV, 2002), which is based on the U.S. Environmental Protection Agency (EPA) functional guidelines for data quality (EPA, 1994; 1999). Data were reviewed to ensure that samples were appropriately processed and analyzed and that the results are valid. All sample data were validated at the Tier I level.

No anomalies were discovered in the data that would discredit any of the sample results. Data met the required data quality indicators (i.e., precision, accuracy, sensitivity, completeness, comparability, and representativeness). The complete datasets, including validation reports, are maintained in the project files and available upon request.

\subsection{USE RESTRICTION}

Use restrictions were not implemented for any of the CASs in CAU 562, and the future land use of any land related to CAU 562 is not restricted from any activity. 


\subsection{CONCLUSIONS AND RECOMMENDATIONS}

\subsection{CONCLUSIONS}

Closure activities began in October 2011 and were completed in April 2012 and included removal and disposal of lead shot, dried paint, impacted soil, a septic tank and contents, and drains, pipes, and traps.

\subsection{Post-Closure REQUiREMENTS}

No use restrictions were implemented, and there are no post-closure requirements.

\subsection{RECOMMENDATIONS}

Because closure activities for CAU 562 have been completed following the CAP for CAU 562 (NNSA/NSO, 2011) as documented in this CR, NNSA/NSO requests the following:

- A Notice of Completion from the Nevada Division of Environmental Protection to NNSA/NSO for closure of CAU 562

- The transfer of CAU 562 from Appendix III to Appendix IV, Closed Corrective Action Units, of the FFACO 
CAU 562 Closure Report

Section: Conclusions and Recommendations

Revision: 0

Date: August 2012

\section{THIS PAGE INTENTIONALLY LEFT BLANK}




\subsection{REFERENCES}

EPA, see U.S. Environmental Protection Agency.

Federal Facility Agreement and Consent Order, 1996 (as amended March 2010). Agreed to by the State of Nevada; U.S. Department of Energy, Environmental Management; U.S. Department of Defense; and U.S. Department of Energy, Legacy Management.

FFACO, see Federal Facility Agreement and Consent Order.

NNSA/NSO, see U.S. Department of Energy, National Nuclear Security Administration Nevada Site Office.

NNSA/NV, see U.S. Department of Energy, National Nuclear Security Administration Nevada Operations Office.

U.S. Department of Energy, National Nuclear Security Administration Nevada Operations Office, 2002. Nevada Environmental Restoration Project Industrial Sites Quality Assurance Project Plan, Nevada Test Site, Nevada. DOE/NV--372-REV.3. Las Vegas, NV.

U.S. Department of Energy, National Nuclear Security Administration Nevada Site Office, 2009. Corrective Action Investigation Plan for Corrective Action Unit 562: Waste Systems, Nevada Test Site, Nevada. DOE/NV--1317. Las Vegas, NV.

U.S. Department of Energy, National Nuclear Security Administration Nevada Site Office, 2010. Corrective Action Decision Document for Corrective Action Unit 562: Waste Systems, Nevada Test Site, Nevada. DOE/NV--1396. Las Vegas, NV.

U.S. Department of Energy, National Nuclear Security Administration Nevada Site Office, 2011. Corrective Action Plan for Corrective Action Unit 562: Waste Systems, Nevada National Security Site, Nevada. DOE/NV--1443. Las Vegas, NV.

U.S. Environmental Protection Agency, 1994. Guidance for the Data Quality Objectives Process. EPA QA/G-4. Washington, D.C.

U.S. Environmental Protection Agency, 1999. Contract Laboratory Program National Functional Guidelines for Organic Data Review. EPA540/R-99/008. Washington, D.C. 
CAU 562 Closure Report

Section: References

Revision: 0

Date: August 2012

THIS PAGE INTENTIONALLY LEFT BLANK 


\section{APPENDIX A*}

\section{DATA QUALITY OBJECTIVES}

*As presented and published in the approved Corrective Action Decision Document/Corrective Action Plan for Corrective Action Unit 562: Waste Systems, Nevada National Security Site, Nevada, 2011, DOE/NV--1443. Las Vegas, NV. 
CAU 562 Closure Report

Section: Appendix A

Revision: 0

Date: August 2012

\section{THIS PAGE INTENTIONALLY LEFT BLANK}


The DQO process described in this appendix is a seven-step strategic systematic planning method used to plan data collection activities and define performance criteria for the CAU 562, Waste Systems, field investigation. The DQOs are designed to ensure that the data collected will provide sufficient and reliable information to identify, evaluate, and technically defend recommended corrective actions (i.e., no further action, closure in place, or clean closure). Existing information about the nature and extent of contamination at the CASs in CAU 562 is insufficient to evaluate and select preferred corrective actions; therefore, a CAI will be conducted.

The CAU 562 investigation will be based on the DQOs presented in this appendix as developed by representatives of the NDEP and the NNSA/NSO. The seven steps of the DQO process presented in Sections A.3.0 through A.9.0 were developed in accordance with Guidance on Systematic Planning Using the Data Quality Objectives Process (EPA, 2006).

The DQO process presents a judgmental sampling approach. In general, the procedures used in the DQO process provide:

- A method to establish performance or acceptance criteria, which serve as the basis for designing a plan for collecting data of sufficient quality and quantity to support the goals of a study.

- Criteria that will be used to establish the final data collection design such as:

- The nature of the problem that has initiated the study and a conceptual model of the environmental hazard to be investigated.

- The decisions or estimates that need to be made and the order of priority for resolving them.

- $\quad$ The type of data needed.

- An analytic approach or decision rule that defines the logic for how the data will be used to draw conclusions from the study findings. 
- Acceptable quantitative criteria on the quality and quantity of the data to be collected, relative to the ultimate use of the data.

- A data collection design that will generate data meeting the quantitative and qualitative criteria specified. A data collection design specifies the type, number, location, and physical quantity of samples and data, as well as the QA and QC activities that will ensure that sampling design and measurement errors are managed sufficiently to meet the performance or acceptance criteria specified in the DQOs. 


\section{A.2.0 Background Information}

The following 13 CASs that comprise CAU 562 are located in Areas 2, 23, and 25 of the NTS, as shown in Figure A.2-1:

- 02-26-11, Lead Shot

- 02-44-02, Paint Spills and French Drain

- 02-59-01, Septic System

- 02-60-01, Concrete Drain

- 02-60-02, French Drain

- 02-60-03, Steam Cleaning Drain

- 02-60-04, French Drain

- 02-60-05, French Drain

- 02-60-06, French Drain

- 02-60-07, French Drain

- 23-60-01, Mud Trap Drain and Outfall

- 23-99-06, Grease Trap

- 25-60-04, Building 3123 Outfalls

Sections A.2.1 through A.2.13 provide a CAS description, physical setting and operational history, release information, and previous investigation results for each CAS in CAU 562. The CAS-specific COPCs are provided in the following sections. Many of the COPCs are based on a conservative evaluation of possible site activities considering the incomplete site histories of the CASs and considering contaminants found at similar NTS sites. Targeted contaminants are defined as those contaminants that are known or that could be reasonably suspected to be present within the CAS based on previous sampling or process knowledge.

\section{A.2.1 CAS 02-26-11, Lead Shot}

Corrective Action Site 02-26-11 consists of releases to the soil from shot that has been abandoned in the former Laborers Storage Area. Figure A.2-2 shows a site sketch of the CAS.

Although the official FFACO name for this CAS is "Lead Shot," initial evaluation has indicated that some of the material may not be lead; therefore, the material will be referred to as "shot" until the analytical results of the material provide the material provide an accurate composition. 


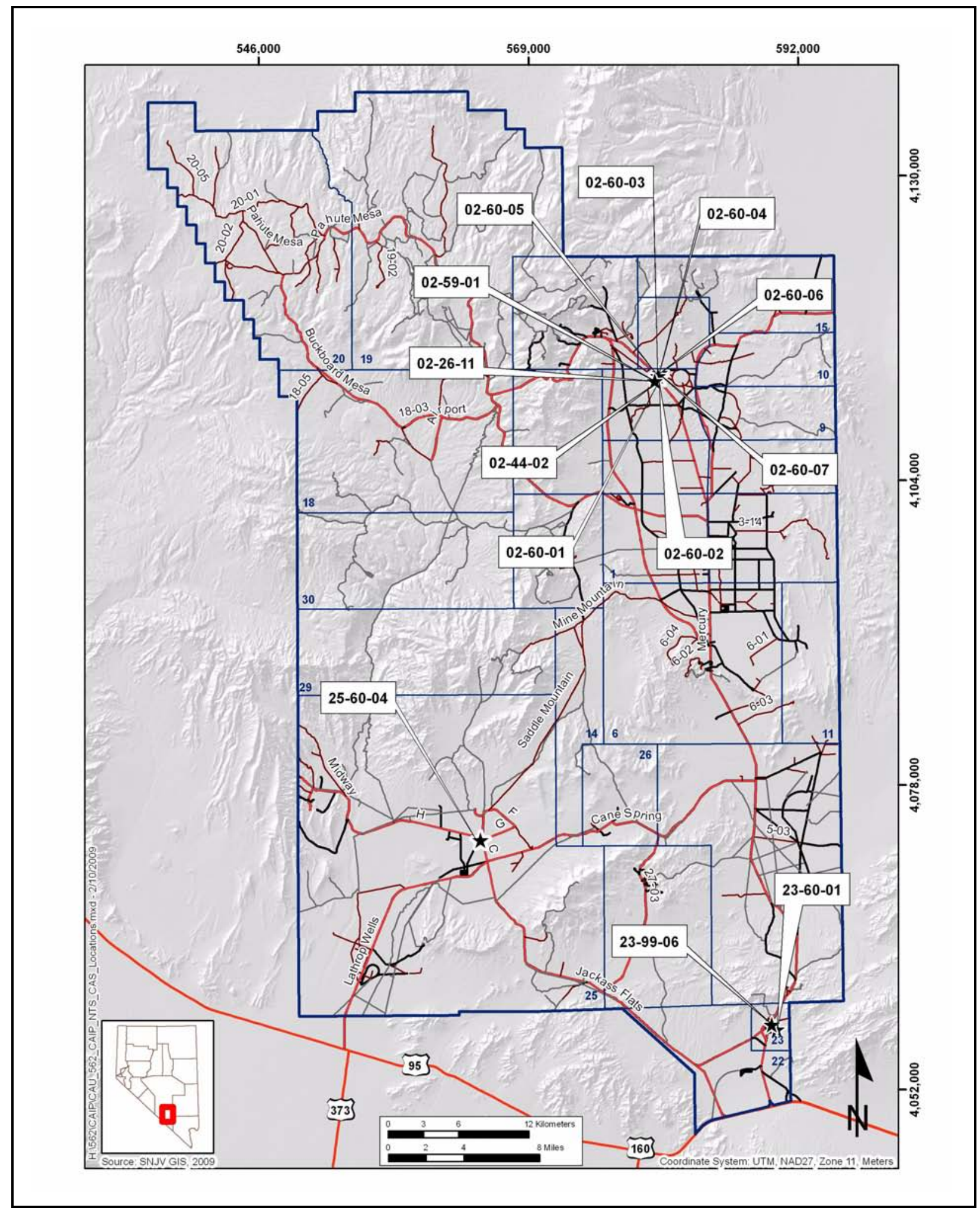

Figure A.2-1 CAU 562, CAS Location Map 


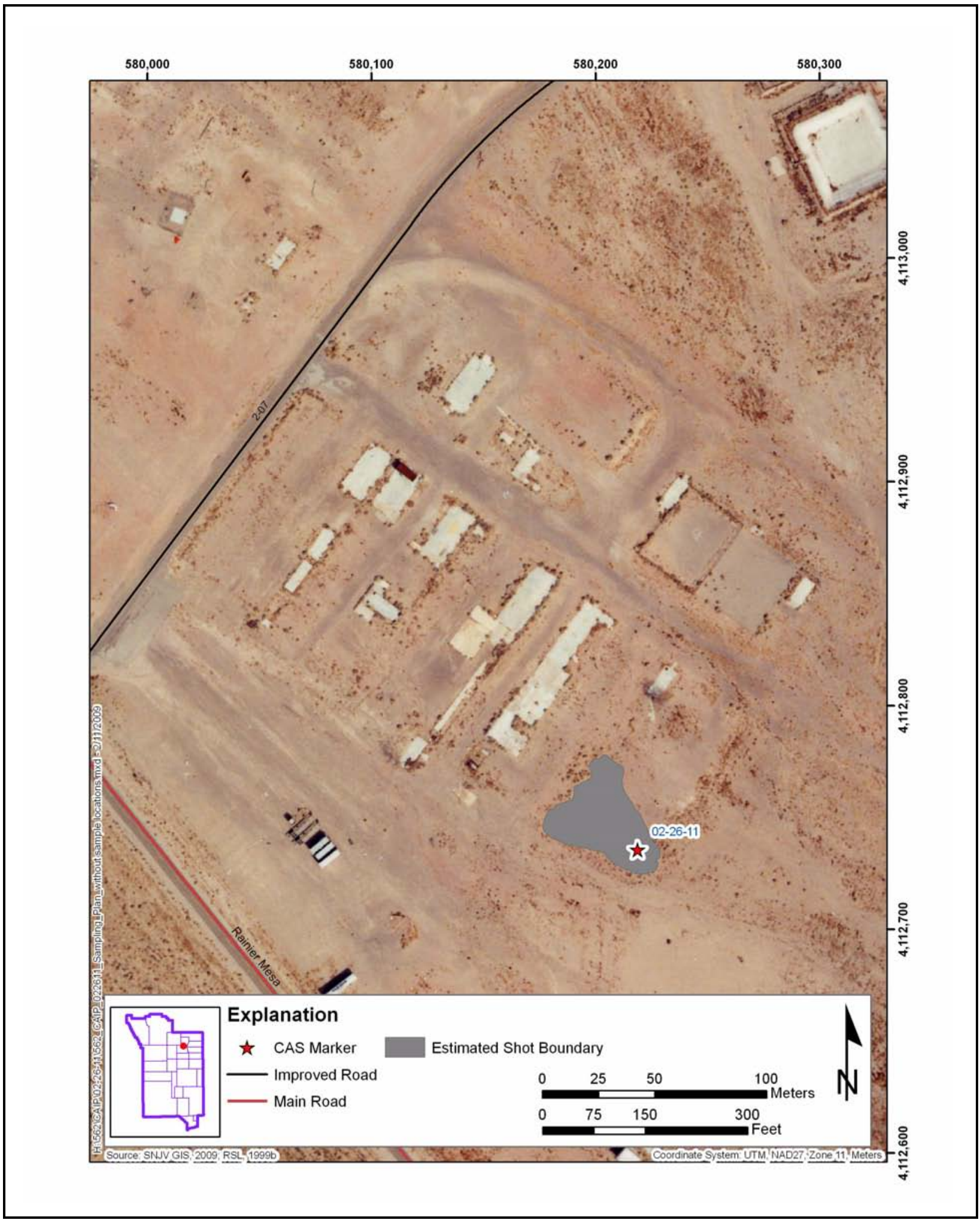

Figure A.2-2

Site Sketch of CAS 02-26-11, Lead Shot 
Physical Setting and Operational History - Corrective Action Site 02-26-11 is located on Yucca Flat in Area 2. The shot was identified in the southwest corner of the former Laborers Storage Area in the Area 2 Camp. The Area 2 Camp was used to support LLNL drilling and construction activities. Although no specific information has been identified discussing the use of the Laborers Storage Area, it is assumed that this area was used to store equipment, tools, materials, and/or other items used by the laborers to conduct work. Additionally, materials used by LLNL to conduct drilling and construction activities may have been stored in this area. It is documented that the shot was stored in the Laborers Storage Area. It is presumed that the shot was either spilled or the packaging for the shot deteriorated (i.e., sandbags).

Corrective Action Site 02-26-11 is located in the upper-central region of Area 2 in the Yucca Flat hydrographic region. Precipitation for the area from 2003 through 2008, as measured at the BJY Station, ranged from 4.33 to 10.43 in./yr, with a mean annual value of 6.73 in. (ARL/SORD, 2008). The mean annual PET rate, as estimated for 2003 through 2008 at the Area 3 RWMS, was 61.71 in. with a 95 percent UCL of 63.07 in. The CAS is located within the Aqueduct Mesa drainage basin, which drains south to Yucca Lake. The area is relatively flat with no nearby drainage channels. The nearest well is USGS WW-2, which is located approximately $0.68 \mathrm{mi}$ northeast of CAS 02-26-11. The depth to groundwater on August 21, 2008, was measured at 2,051.1 ft bgs (USGS, 2008). The soil at CAS 02-26-11 appears native and consists of sand to cobble-sized alluvium of various lithologies. Although the soil is native, the area has been disturbed due to the construction of numerous facilities in the surrounding area.

Release Information - The release at this CAS includes any lead or other metals that may have leached out of the shot to the underlying soil. No visible soil stains or other biasing factors are present within the footprint of the shot.

Previous Investigation Results - Previous investigations at this CAS include a site visit. The shot consists of various sized, small-diameter shot. The shot present in some portions of the site boundary is rusted and has been fused together. Other shot in the site boundary is gray and of smaller diameter. The shot is concentrated in a number of areas throughout the site boundary but is scattered thinly throughout the remainder of the area. The area is moderately vegetated with large bushes. 


\section{A.2.2 CAS 02-44-02, Paint Spills and French Drain}

Corrective Action Site 02-44-02 consists of the soil impacted by the paint, historical spill, and french drain. Figure A.2-3 shows a site sketch of the CAS.

Physical Setting and Operational History - Corrective Action Site 02-44-02 is located on Yucca Flat in Area 2. The CAS components were identified in the vicinity of the Painters Shed, Shop, and Storage Rack in the Area 2 Camp. The Area 2 Camp was used to support LLNL drilling and construction activities. Although no specific information has been identified discussing the use of the painters buildings, it is assumed that this area was used to support the painters' activities and to store paint, equipment, tools, materials, and/or other items used by the painters to conduct work. These activities resulted in paint spills and the historical spill. It is unknown how the french drain was associated with the painters’ activities.

Corrective Action Site 02-44-02 is located in the upper-central region of Area 2 in the Yucca Flat hydrographic region. Precipitation for the area from 2003 through 2008, as measured at the BJY Station, ranged from 4.33 to 10.43 in./yr, with a mean annual value of 6.73 in. (ARL/SORD, 2008). The mean annual PET rate, as estimated for 2003 through 2008 at the Area 3 RWMS, was 61.71 in. with a 95 percent UCL of 63.07 in. The CAS is located within the Aqueduct Mesa drainage basin, which drains south to Yucca Lake. The area is relatively flat with no nearby drainage channels. The nearest well is USGS WW-2, which is located approximately $0.68 \mathrm{mi}$ northeast of CAS 02-44-02. The depth to groundwater on August 21, 2008, was measured at 2,051.1 ft bgs (USGS, 2008). The soil at CAS 02-44-02 appears native and consists of sand to cobble-sized alluvium of various lithologies. Although the soil is native, the area has been disturbed due to the construction of numerous facilities in the surrounding area.

Release Information - The release at this CAS include any paint or other material that may have spilled on or around the three painters facilities as well as any releases from the french drain. Scaling paint is found on the Painters Shed foundation, and paint spills are on the concrete pad and soil by the Paint Storage Rack. Documentation indicates that a spill, possibly of resin, occurred adjacent to the Paint Shop, although no staining is currently visible. No staining is visible around the french drain or on the sediment visible at the base of the drain. 


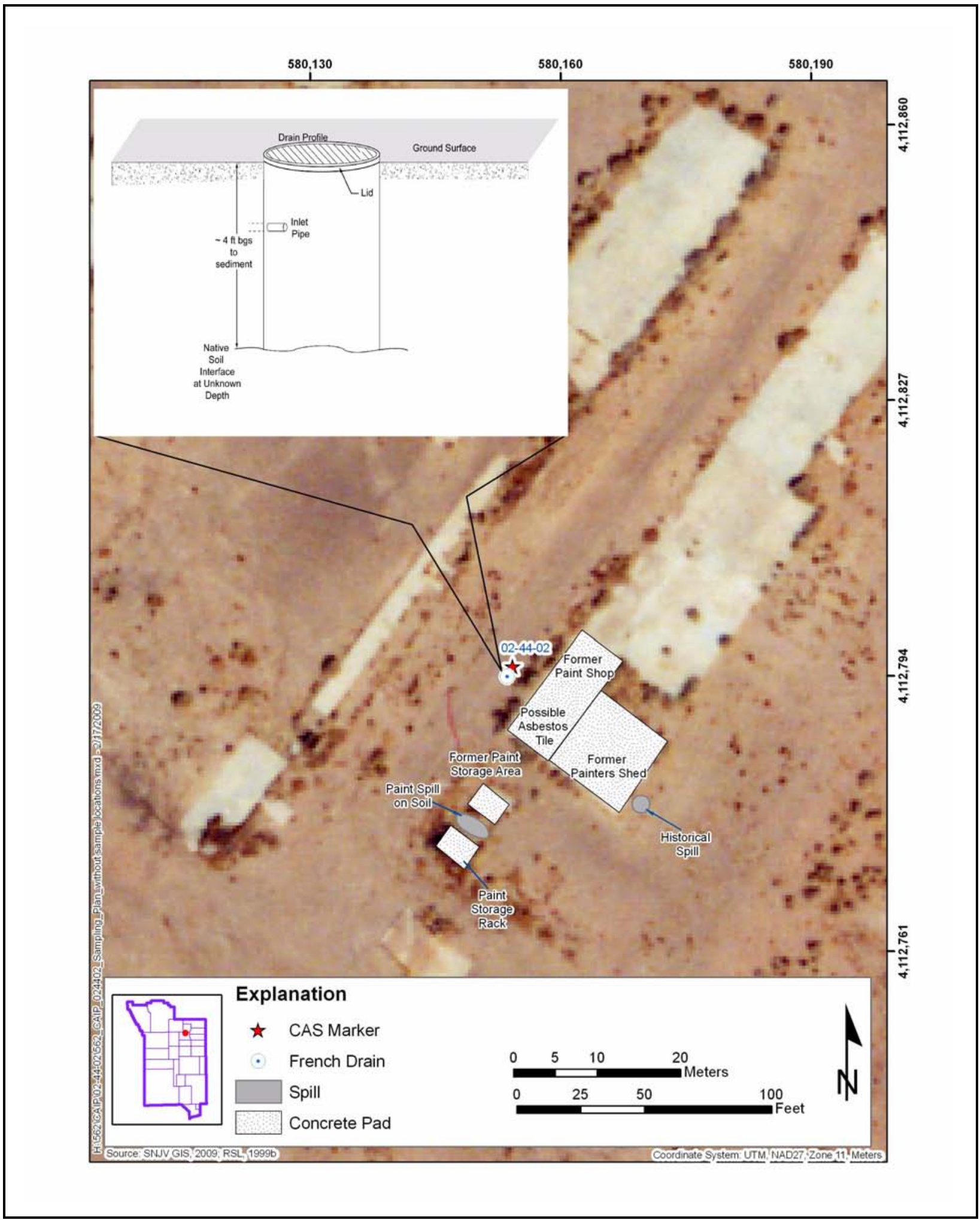

Figure A.2-3

Site Sketch of CAS 02-44-02, Paint Spills and French Drain 
Previous Investigation Results - Previous investigations at this CAS include a site visit. The french drain is located approximately $8 \mathrm{ft}$ northwest of the Paint Shop building foundation. The french drain is $2 \mathrm{ft}$ in diameter and has a 1- to 2-in. diameter inlet pipe coming from the direction of the former Paint Shop. The source of the piping is unknown. Soil or sediment is visible at approximately $4 \mathrm{ft}$ bgs. The casing for the drain appears to be double lined, with no visible perforations in the casing.

A 20-by-20-ft area of paint stains and scaling paint is present on the Paint Shed building foundation. Additional paint is present on the soil and concrete pad at the Paint Storage Rack. The storage rack surrounds a concrete pad that is stained by paint. The paint spills on the soil adjacent to the outside of the northeastern side of the rack range from 1 to 2 in. thick and have been mixed in with soil. The paint spills cover an area approximately 15 by $3 \mathrm{ft}$. The remaining sides of the rack are surrounded by vegetation, so the extent of paint spills, if any, is unknown.

A historical spill was documented as having occurred adjacent to the southeastern edge of the former Painters Shed foundation. The spill was not visible during the field investigation, but the coordinates of the spill were provided in a historical document (REECo, 1995).

\section{A.2.3 CAS 02-59-01, Septic System}

Corrective Action Site 02-59-01 consists of the soil impacted by the septic system. Figure A.2-4 shows a site sketch of the CAS.

Physical Setting and Operational History - Corrective Action Site 02-59-01 is located on Yucca Flat in Area 2. The CAS was identified adjacent to a cable runway in the Area 2 Camp, which was used to support LLNL drilling and construction activities. The LLNL Warehouse, Field Operations Support Facility, Photo Skid Trailer, Conference Room Trailer, and Cable Fabrication Building discharged to the septic system via toilets, sinks, service sinks, floor drains, and shower drains. The buildings have been demolished, but the trailers remain on site. The septic system is located south of the Conference Room Trailer. Cable spools are still being stored in the vicinity of the leachfield.

Corrective Action Site 02-59-01 is located in the upper central region of Area 2 in the Yucca Flat hydrographic region. Precipitation for the area from 2003 through 2008, as measured at the BJY 


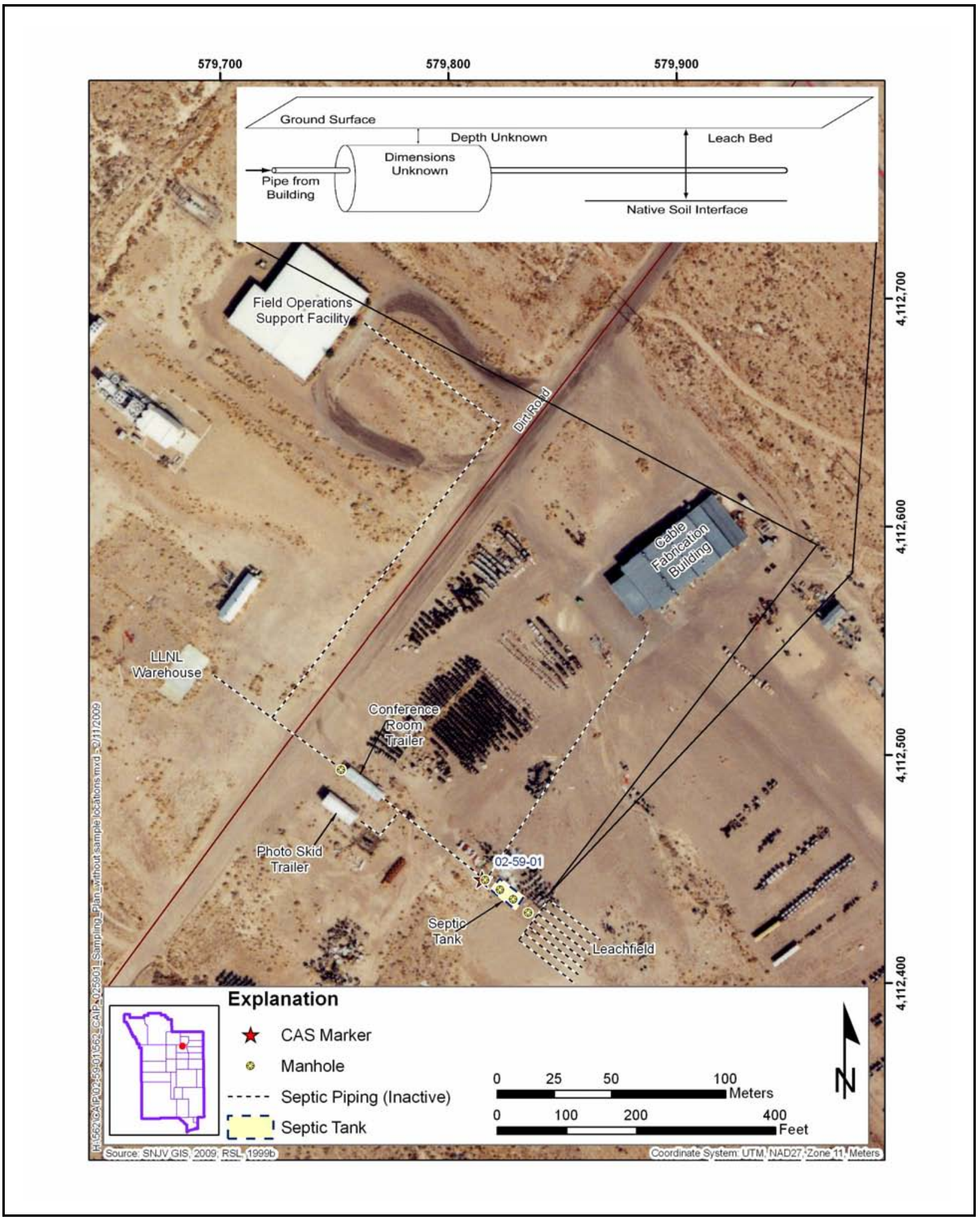

Figure A.2-4

Site Sketch of CAS 02-59-01, Septic System 
Station, ranged from 4.33 to 10.43 in./yr, with a mean annual value of 6.73 in. (ARL/SORD, 2008). The mean annual PET rate, as estimated for 2003 through 2008 at the Area 3 RWMS, was 61.71 in. with a 95 percent UCL of 63.07 in. The CAS is located within the Aqueduct Mesa drainage basin, which drains south to Yucca Lake. The area is relatively flat with no nearby drainage channels. The nearest well is USGS WW-2, which is located approximately $1 \mathrm{mi}$ northeast of CAS 02-59-01. The depth to groundwater on August 21, 2008, was measured at 2,051.1 ft bgs (USGS, 2008). The soil at CAS 02-59-01 appears native and consists of sand to cobble-sized alluvium of various lithologies. Although the soil is native, the area has been disturbed due to the construction of numerous facilities in the surrounding area.

Release Information - The release at this CAS includes the effluent from the buildings to the septic system. The contents of the tank are unknown; however, if material is present in the tank, there is a possibility that this PSM could be released if the tank containment fails at any time in the future.

Previous Investigation Results - Previous investigations at this CAS include a site visit. Because the septic tank and leachfield are subsurface, the four access manholes identify the location of the septic tank, and the northern-center-most portion of the leachfield. Another manhole is present north of the septic system, near the Conference Room Trailer. No other visible indicators of the system are present. Drawings show that the leachfield has seven leachlines and is $40 \mathrm{ft}$ long by $35 \mathrm{ft}$ wide. Based on these dimensions, a portion of the leachfield, and possibly the septic tank, is covered by cable spools that have been stored in the area.

\section{A.2.4 CAS 02-60-01, Concrete Drain}

Corrective Action Site 02-60-01 consists of the soil potentially impacted by releases from the concrete drain. Figure A.2-5 shows a site sketch of the CAS.

Physical Setting and Operational History - Corrective Action Site 02-60-01 is located on Yucca Flat in Area 2. The CAS was identified adjacent to the Area 2 Tank Farm and Operations Warehouse in the Area 2 Camp, which was used to support LLNL drilling and construction activities. Although no specific information has been identified discussing the use of the Area 2 Tank Farm and Operations Warehouse, documentation states that a 2-in. rubber hose ran from the building to the covered concrete drain. It is unknown whether there is any piping associated with the concrete drain or what 


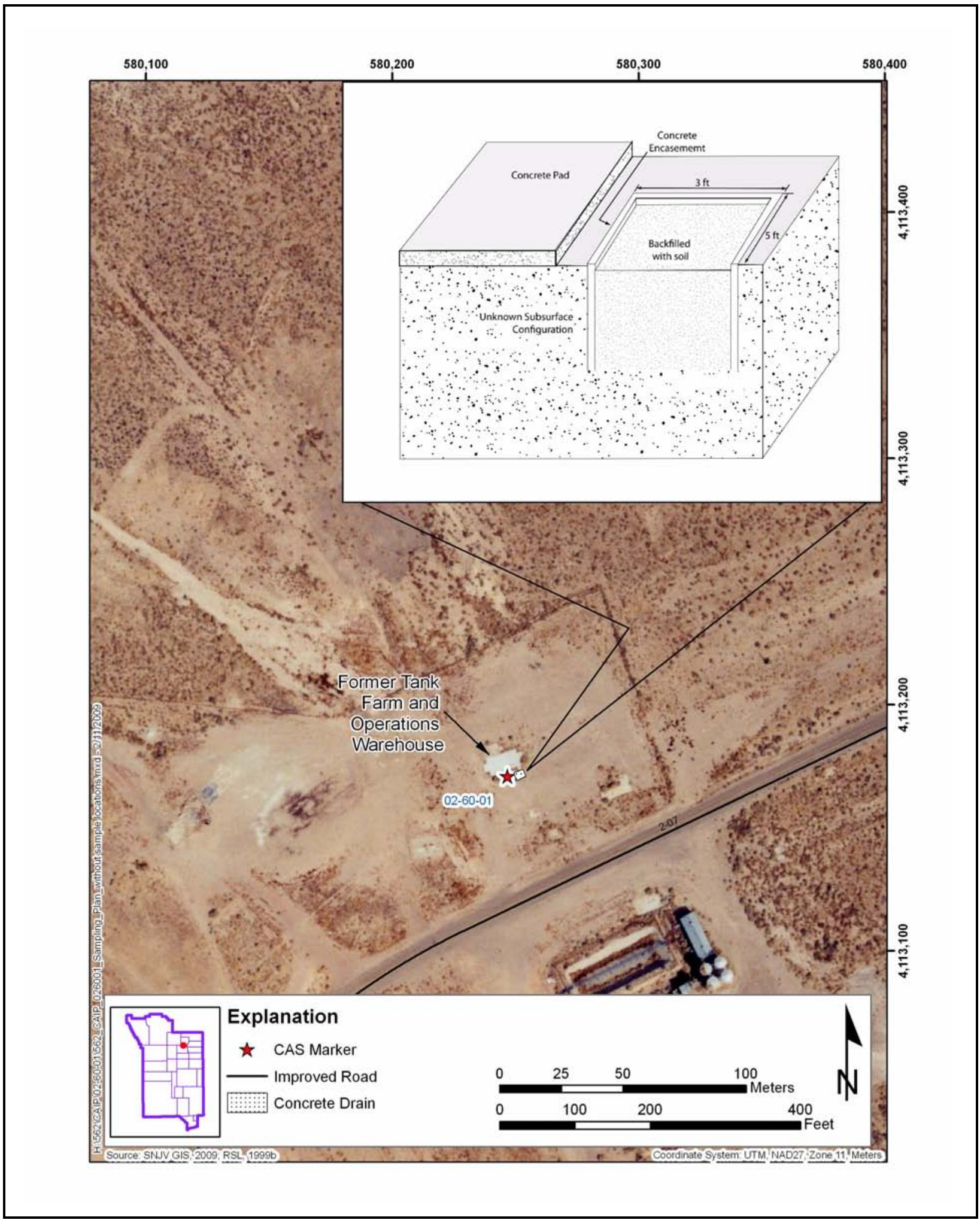

Figure A.2-5

Site Sketch of CAS 02-60-01, Concrete Drain 
source discharged to the concrete drain. The Area 2 Tank Farm and Operations Warehouse has been demolished. All that remains is the building foundation and the concrete drain located adjacent to the southern edge of the foundation.

Corrective Action Site 02-60-01 is located in the upper-central region of Area 2 in the Yucca Flat hydrographic region. Precipitation for the area from 2003 through 2008, as measured at the BJY Station, ranged from 4.33 to 10.43 in./yr, with a mean annual value of 6.73 in. (ARL/SORD, 2008). The mean annual PET rate, as estimated for 2003 through 2008 at the Area 3 RWMS, was 61.71 in. with a 95 percent UCL of 63.07 in. The CAS is located within the Aqueduct Mesa drainage basin, which drains south to Yucca Lake. The area is relatively flat with no nearby drainage channels. The nearest well is USGS WW-2, which is located approximately $0.51 \mathrm{mi}$ northeast of CAS 02-60-01. The depth to groundwater on August 21, 2008, was measured at 2,051.1 ft bgs (USGS, 2008). The soil at CAS 02-60-01 appears native and consists of sand to cobble-sized alluvium of various lithologies. Although the soil is native, the area has been disturbed due to the construction of numerous facilities in the surrounding area.

Release Information - The release at this CAS includes effluent discharged to the soil surrounding the concrete drain. It is unknown whether the drain is enclosed or whether the effluent drained to the subsurface. No staining is visible around the concrete drain, and because the drain has been backfilled, it is unknown whether PSM exists at the base of the drain.

Previous Investigation Results - Previous investigations at this CAS include a site visit and a geophysical survey. Currently, no cover is present on the drain, and the drain has been backfilled with native soil. A portion of the concrete border of the drain is still visible. The drain is adjacent to the southern side of the Area 2 Tank Farm and Operations Warehouse building foundation. A geophysical survey was completed of the concrete drain to determine whether piping was associated with this feature. There were no linear anomalies consistent with piping; however, two anomalies were identified directly outside the concrete encasement (Weston, 2007). It was noted that these were not a result of surface metal but could possibly be buried metal because the area has been disturbed. Further investigation is required to identify these anomalies. 


\section{A.2.5 CAS 02-60-02, French Drain}

Corrective Action Site 02-60-02 consists of the soil potentially impacted by releases from the french drain and elongated drains adjacent to the building foundation. Figure A.2-6 shows a site sketch of the CAS.

Physical Setting and Operational History - Corrective Action Site 02-60-02 is located on Yucca Flat in Area 2. The CAS was identified adjacent to the former Sheet Metal and Pipefitters Shop in the Area 2 Camp, which was used to support LLNL drilling and construction activities. Although no specific information has been identified discussing the exact use of the Sheet Metal and Pipefitters Shop, it is assumed that effluent from activities at this building was discharged to both the french drain and the elongated drains that are present along the northwestern side of the building foundation. It is unknown what source discharged to the drains. The Sheet Metal and Pipefitters Shop has been demolished, and the building foundation and drains are all that remain.

Corrective Action Site 02-60-02 is located in the upper-central region of Area 2 in the Yucca Flat hydrographic region. Precipitation for the area from 2003 through 2008, as measured at the BJY Station, ranged from 4.33 to 10.43 in./yr, with a mean annual value of 6.73 in. (ARL/SORD, 2008). The mean annual PET rate, as estimated for 2003 through 2008 at the Area 3 RWMS, was 61.71 in. with a 95 percent UCL of 63.07 in. The CAS is located within the Aqueduct Mesa drainage basin, which drains south to Yucca Lake. The area is relatively flat with no nearby drainage channels. The nearest well is USGS WW-2, which is located approximately $0.66 \mathrm{mi}$ northeast of CAS 02-60-02. The depth to groundwater on August 21, 2008, was measured at 2,051.1 ft bgs (USGS, 2008). The soil at CAS 02-60-02 appears native and consists of sand to cobble-sized alluvium of various lithologies. Although the soil is native, the area has been disturbed due to the construction of numerous facilities in the surrounding area.

Release Information - The release at this CAS includes effluent discharged to the soil surrounding the drains. The casing of the french drain is perforated so effluent would have been released to the surrounding soil. The elongated drains do not appear to be enclosed; therefore, the surrounding soil has likely been impacted by effluent discharged to the drain. No staining is visible around the drains or in the sediment present within the drains. 


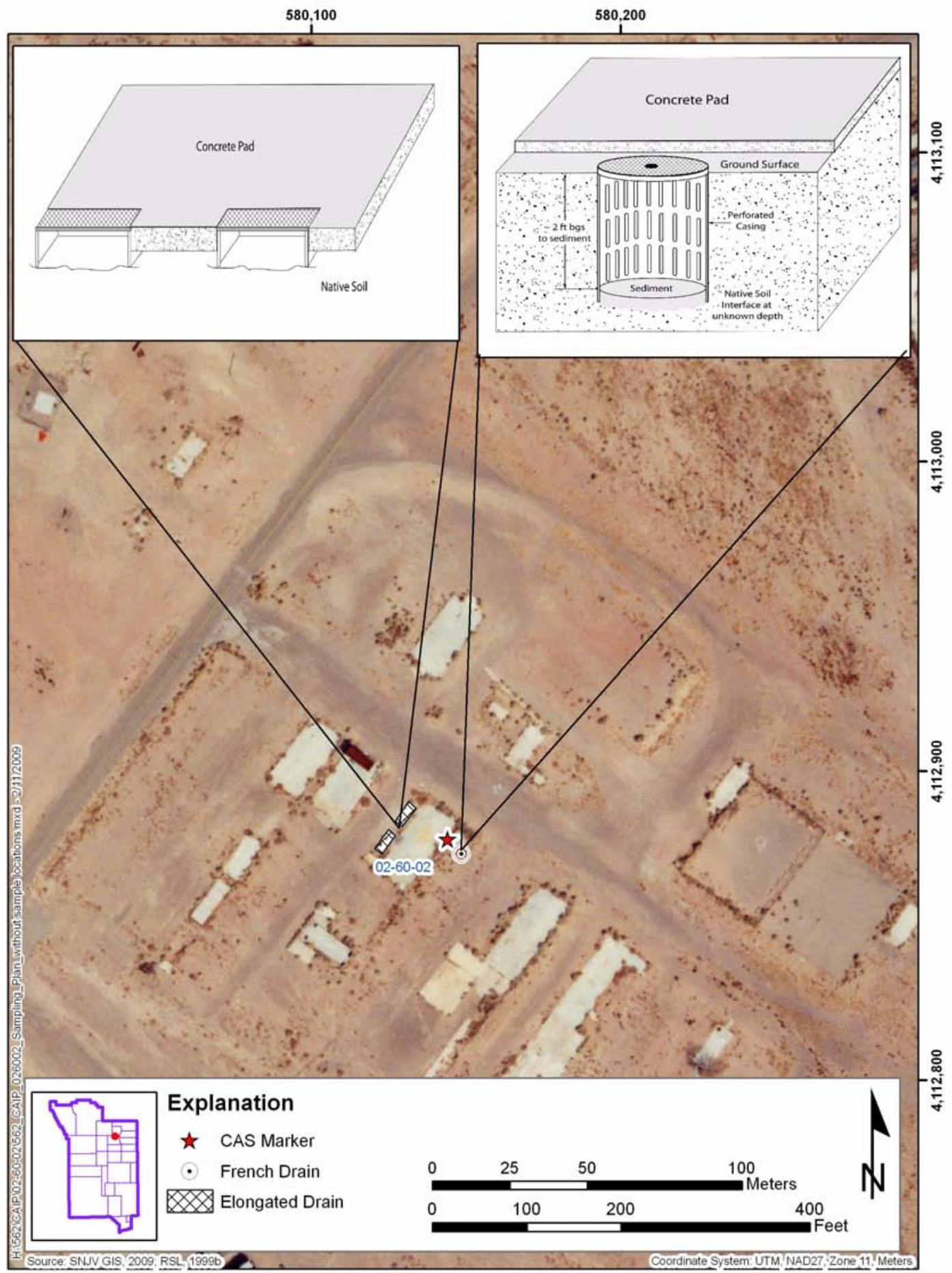

Figure A.2-6

Site Sketch of CAS 02-60-02, French Drain 
Previous Investigation Results - Previous investigations of CAS 02-60-02 consist of a site visit and a geophysical survey. The french drain is covered by a thin, circular piece of steel with a small hole cut out of the center. The casing of the drain is perforated, and sediment is present at approximately $2 \mathrm{ft}$ bgs. The two elongated drains are covered by a removable metal grate, and sediment is at the base of both drains. The drains do not appear to be enclosed, and there is no visual evidence of piping. A geophysical survey was conducted around the two elongated drains; no linear or other anomalies were identified (Weston, 2007). The french drain is located on the southeast side of the Sheet Metal and Pipefitters Shop building foundation, while the elongated drains are located on the edge of the northwestern side of the concrete pad.

\section{A.2.6 CAS 02-60-03, Steam Cleaning Drain}

Corrective Action Site 02-60-03 consists of the soil potentially impacted by releases from the steam cleaning sump and the drain/outfall that discharges from an adjacent concrete pad. Figure A.2-7 shows a site sketch of the CAS.

Physical Setting and Operational History - Corrective Action Site 02-60-03 is located on Yucca Flat in Area 2. The CAS was identified adjacent to the former Linemans Shop in the Area 2 Camp, which was used to support LLNL drilling and construction activities. Documentation states that historical steam cleaning activities took place in the Area 2 Camp, specifically in the Linemans Yard, Mechanics Yard, and Reefer Shop Yard. Equipment parts, air conditioner exteriors, and tunnel and heavy construction equipment were listed as items that were cleaned in these yards. Although no specific information has been identified discussing the exact equipment steam cleaned at CAS 02-60-03, it is assumed that equipment and vehicles from the Linemans Yard, and possibly the other yards mentioned, were decontaminated at this location.

Corrective Action Site 02-60-03 is located in the upper-central region of Area 2 in the Yucca Flat hydrographic region. Precipitation for the area from 2003 through 2008, as measured at the BJY Station, ranged from 4.33 to 10.43 in./yr, with a mean annual value of 6.73 in. (ARL/SORD, 2008). The mean annual PET rate, as estimated for 2003 through 2008 at the Area 3 RWMS, was 61.71 in. with a 95 percent UCL of 63.07 in. The CAS is located within the Aqueduct Mesa drainage basin, which drains south to Yucca Lake. The area is relatively flat with no nearby drainage channels. The nearest well is USGS WW-2, which is located approximately 0.72 mi northeast of CAS 02-60-03. 


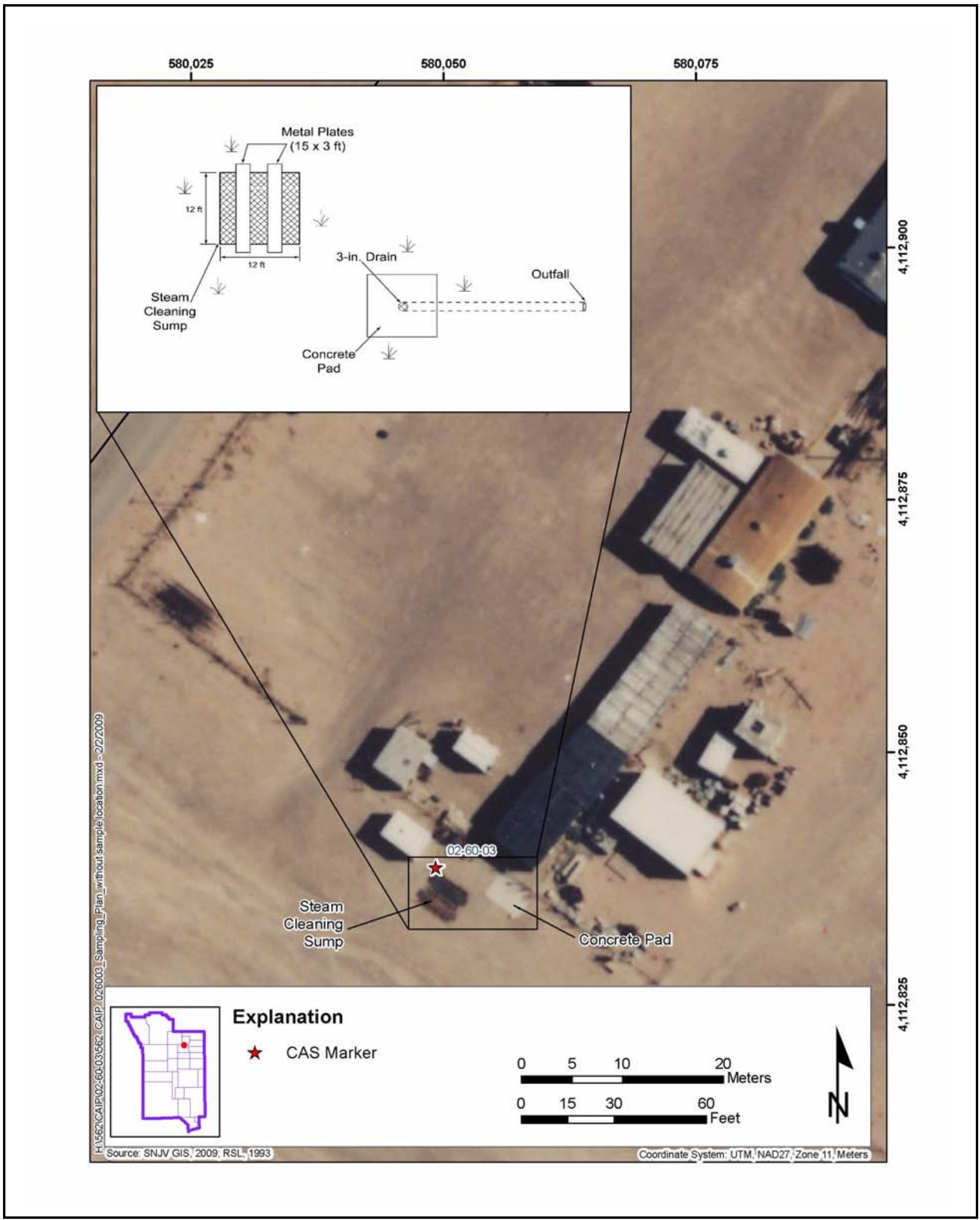

Figure A.2-7

Site Sketch of CAS 02-60-03, Steam Cleaning Drain 
The depth to groundwater on August 21, 2008, was measured at 2,051.1 ft bgs (USGS, 2008). The soil at CAS 02-60-03 appears native and consist of sand to cobble-sized alluvium of various lithologies. Although the soil is native, the area has been disturbed due to the construction of numerous facilities in the surrounding area.

Release Information - The release at this CAS includes effluent discharged to the soil at the sump and drain/outfall location. As items were cleaned over the sump and on the concrete pad, there could have been runoff to the surrounding soil. It is unknown whether the base of the sump is open so that effluent would have been released directly to the soil below the sump. A drain in the center of the concrete pad presumably leads to the outfall, which is open to daylight and where effluent would have been discharged. No staining is visible around the sump or concrete pad and outfall location.

Previous Investigation Results - Previous investigations of CAS 02-60-03 consist of a site visit. The sump is covered by a metal grate that measures 12 by $12 \mathrm{ft}$ and is configured for holding vehicles. Vegetation exists below the grate, so the base of the sump is not visible. The concrete pad with the 3-in. drain in the center is approximately $10 \mathrm{ft}$ east of the sump. An open-ended, gray plastic pipe extends approximately $15 \mathrm{ft}$ northeast from the concrete pad. The majority of the pipe is visible at the ground surface; however, a portion of the pipe is covered by uncompacted soil.

\section{A.2.7 CAS 02-60-04, French Drain}

Corrective Action Site 02-60-04 consists of the soil potentially impacted by releases from the french drain. Figure A.2-8 shows a site sketch of the CAS.

Physical Setting and Operational History - Corrective Action Site 02-60-04 is located on Yucca Flat in Area 2. The CAS was identified in a concrete pad adjacent to the former Refrigeration Shop in the Area 2 Camp, which was used to support LLNL drilling and construction activities. Although no specific information has been identified discussing the use of the french drain, it is assumed that the french drain was used in conjunction with activities at the Refrigeration Shop (i.e., cleaning parts and equipment on the concrete pad, disposal of fluids from the shop).

Corrective Action Site 02-60-04 is located in the upper-central region of Area 2 in the Yucca Flat hydrographic region. Precipitation for the area from 2003 through 2008, as measured at the BJY 


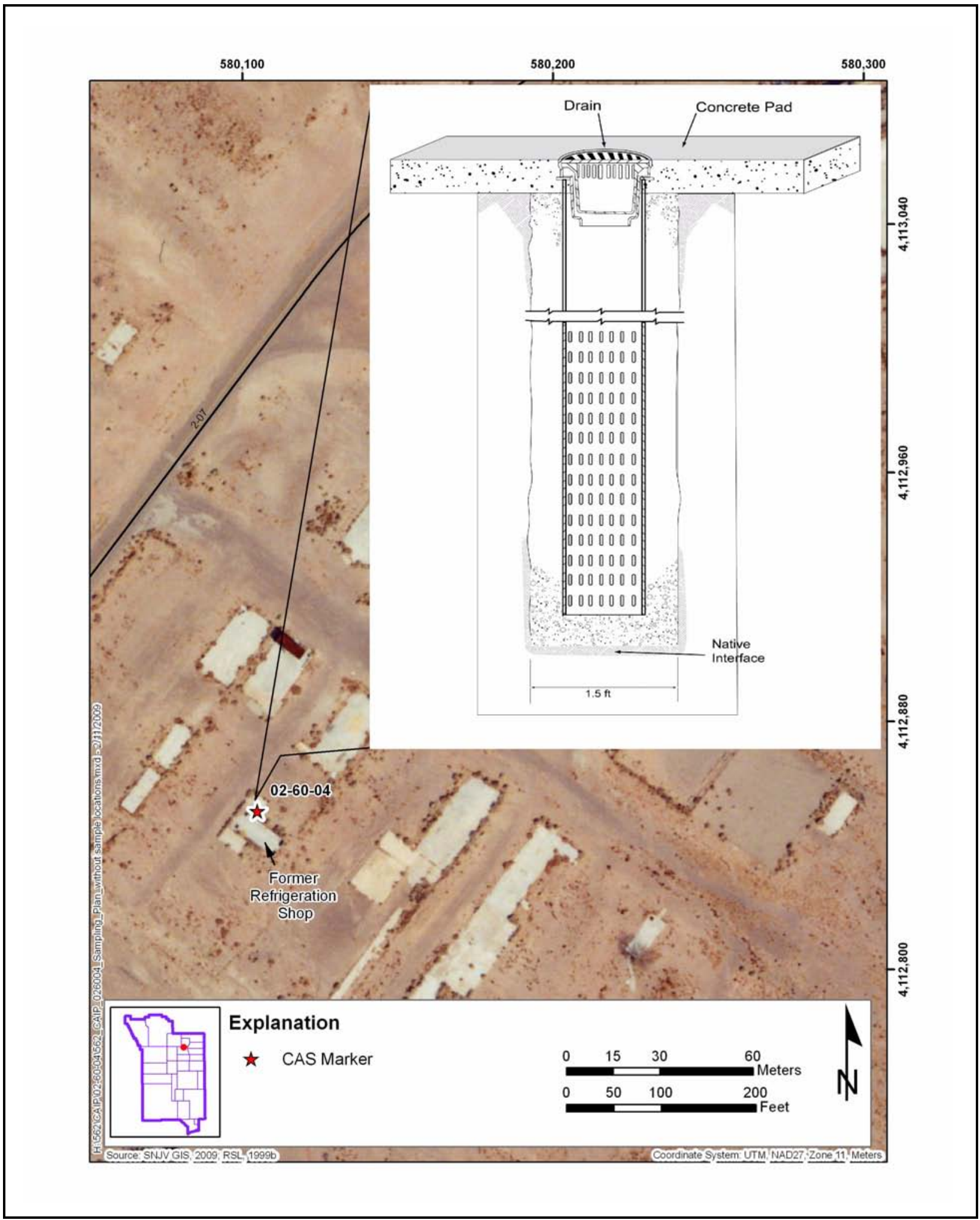

Figure A.2-8

Site Sketch of CAS 02-60-04, French Drain 
Station, ranged from 4.33 to 10.43 in./yr, with a mean annual value of 6.73 in. (ARL/SORD, 2008). The mean annual PET rate, as estimated for 2003 through 2008 at the Area 3 RWMS, was 61.71 in. with a 95 percent UCL of 63.07 in. The CAS is located within the Aqueduct Mesa drainage basin, which drains south to Yucca Lake. The area is relatively flat with no nearby drainage channels. The nearest well is USGS WW-2, which is located approximately 0.69 mi northeast of CAS 02-60-04. The depth to groundwater on August 21, 2008, was measured at 2,051.1 ft bgs (USGS, 2008). The soil at CAS 02-60-04 appears native and consists of sand to cobble-sized alluvium of various lithologies. Although the soil is native, the area has been disturbed due to the construction of numerous facilities in the surrounding area.

Release Information - The release at this CAS includes effluent discharged to the soil via the french drain. The casing of the drain is perforated so that effluent could drain into the pea gravel pack that surrounds the casing. Ultimately, the effluent was released to the subsurface soil.

Previous Investigation Results - Previous investigations of CAS 02-60-04 consist of a site visit. A 12-in. diameter drain lid is present on the center of a concrete pad. A drawing show the drain casing extends $8.5 \mathrm{ft}$ bgs and is surrounded by a $1.5 \mathrm{ft}$ pea gravel pack. Soil and vegetation is present at about $1.5 \mathrm{ft}$ below the drain lid. According to the drawing, a bucket sits on top of the casing, so the soil and vegetation may have been deposited in the bucket over time; therefore, the entire drain casing may not have been backfilled with soil. The casing is perforated but closed at the base.

\section{A.2.8 CAS 02-60-05, French Drain}

Corrective Action Site 02-60-05 consists of the soil potentially impacted by releases from the french drain. Figure A.2-9 shows a site sketch of the CAS.

Physical Setting and Operational History - Corrective Action Site 02-60-05 is located on Yucca Flat in Area 2. The CAS was identified adjacent to the former Operators Office and the D-38 Storage Yard in the Area 2 Camp, which was used to support LLNL drilling and construction activities. Documentation states that the french drain was used as a hand washing station, perhaps by personnel occupying the Operators Office or working in the storage yard. No other information has been identified discussing the use and details of the french drain. 


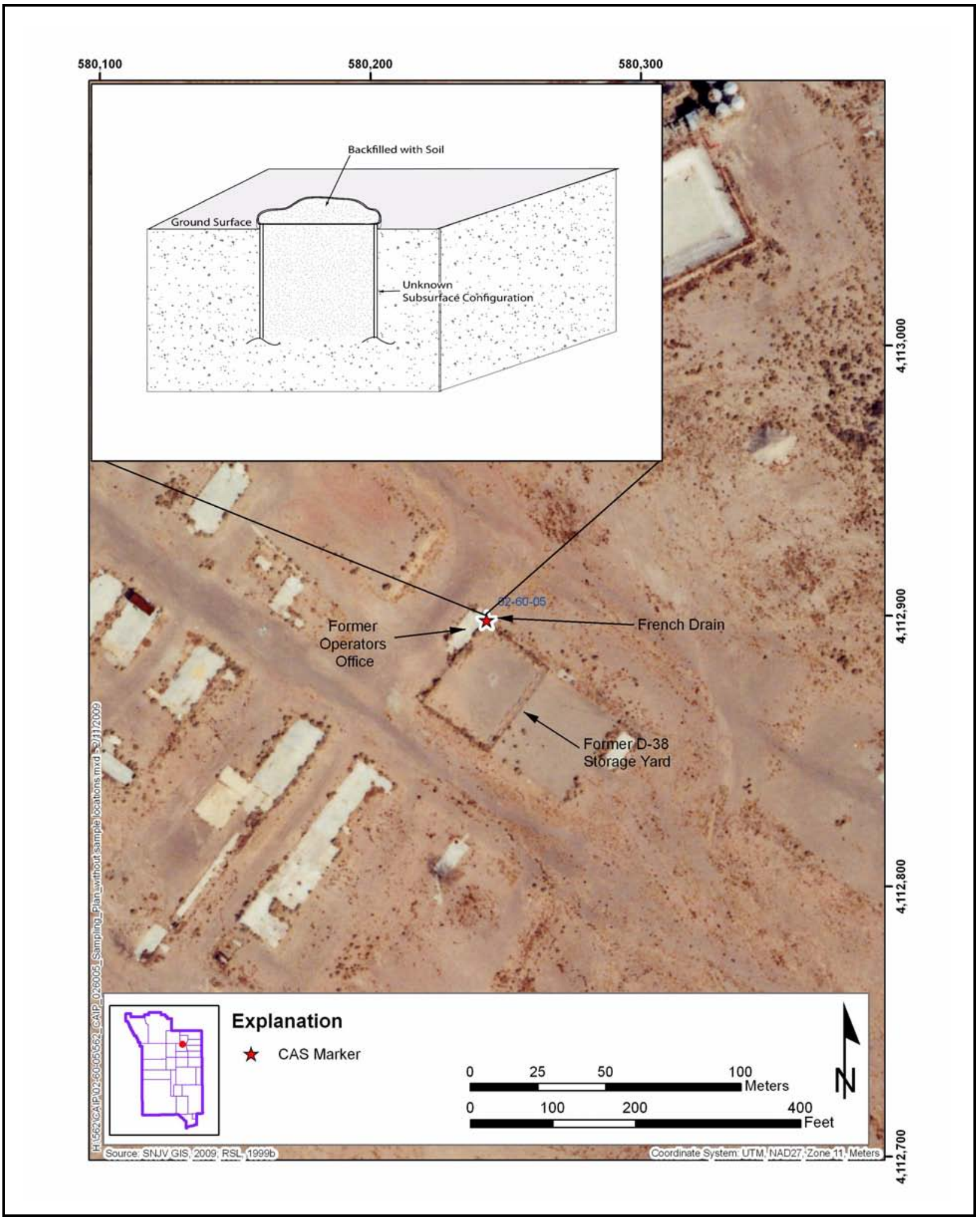

Figure A.2-9

Site Sketch of CAS 02-60-05, French Drain 
Corrective Action Site 02-60-05 is located in the upper-central region of Area 2 in the Yucca Flat hydrographic region. Precipitation for the area from 2003 through 2008, as measured at the BJY Station, ranged from 4.33 to 10.43 in./yr, with a mean annual value of 6.73 in. (ARL/SORD, 2008). The mean annual PET rate, as estimated for 2003 through 2008 at the Area 3 RWMS, was 61.71 in. with a 95 percent UCL of 63.07 in. The CAS is located within the Aqueduct Mesa drainage basin, which drains south to Yucca Lake. The area is relatively flat with no nearby drainage channels. The nearest well is USGS WW-2, which is located approximately $0.60 \mathrm{mi}$ northeast of CAS 02-60-05. The depth to groundwater on August 21, 2008, was measured at 2,051.1 ft bgs (USGS, 2008). The soil at CAS 02-60-05 appears native and consists of sand to cobble-sized alluvium of various lithologies. Although the soil is native, the area has been disturbed due to the construction of numerous facilities in the surrounding area.

Release Information - The release at this CAS includes effluent discharged to the french drain. It is unknown whether the drain is perforated or open at the base. No staining is visible around the french drain.

Previous Investigation Results - Previous investigations of CAS 02-60-05 consist of a site visit. The french drain may be a buried 55-gallon drum that has since been backfilled with native soil. The interior of the drain casing cannot be viewed. The rim of the casing is approximately 2 in. above ground surface and has been misshapen over time. The french drain is approximately $1 \mathrm{ft}$ from the D-38 Storage Yard fencing. Vegetation is fairly dense in the area of the drain.

\section{A.2.9 CAS 02-60-06, French Drain}

Corrective Action Site 02-60-06 consists of the soil potentially impacted by releases from the french drain. Figure A.2-10 shows the location of the CAS.

Physical Setting and Operational History - Corrective Action Site 02-60-06 is located on Yucca Flat in Area 2. The CAS was identified adjacent to the former Electricians Shop in the Area 2 Camp, which was used to support LLNL drilling and construction activities. Documentation states that the french drain was used as a hand washing station, perhaps by personnel occupying the Electricians Shop. No other information has been identified discussing the use and details of the french drain. 


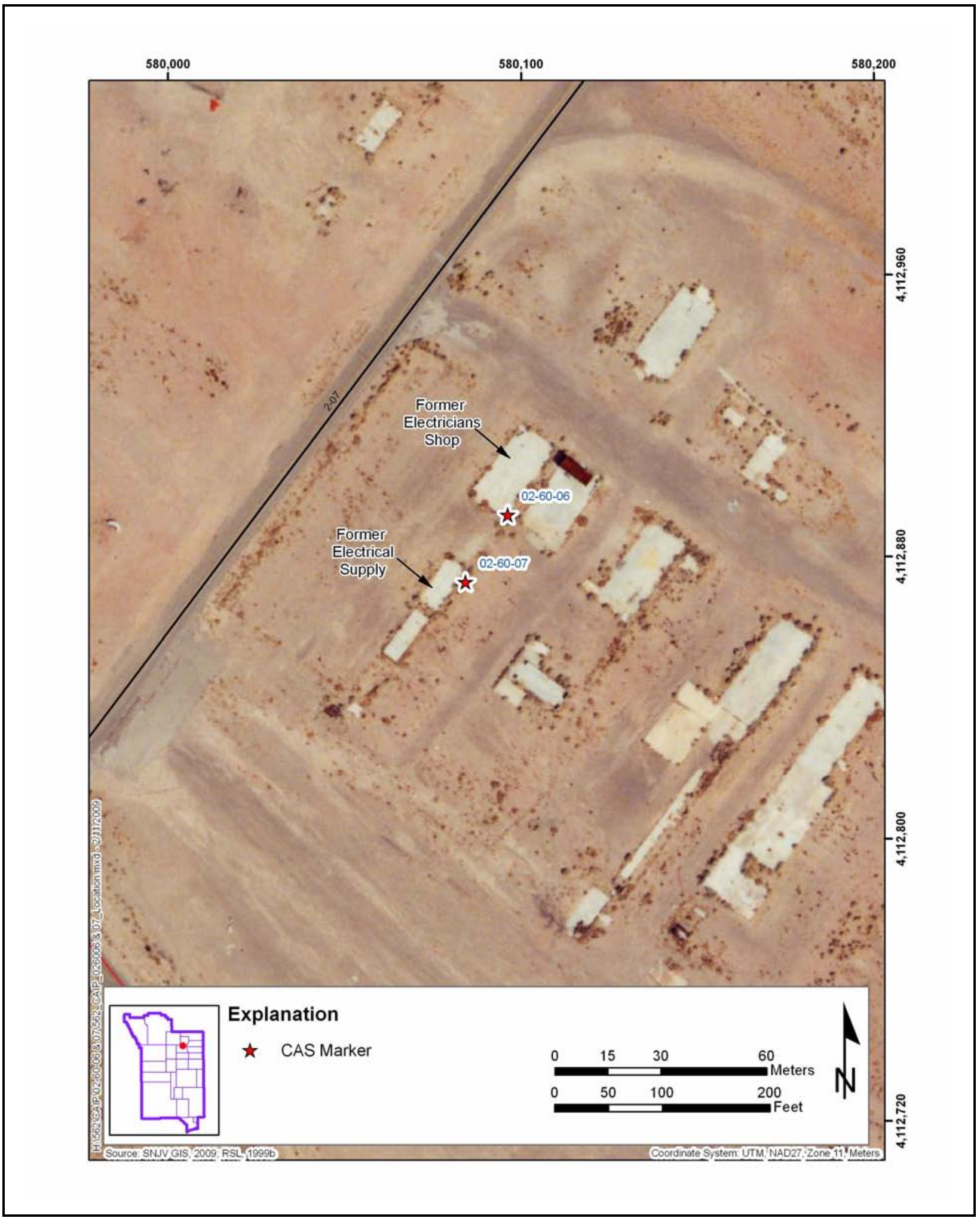

Figure A.2-10

Site Sketch of CASs 02-60-06, French Drain, and 02-60-07, French Drain 
Corrective Action Site 02-60-06 is located in the upper-central region of Area 2 in the Yucca Flat hydrographic region. Precipitation for the area from 2003 through 2008, as measured at the BJY Station, ranged from 4.33 to 10.43 in./yr, with a mean annual value of 6.73 in. (ARL/SORD, 2008). The mean annual PET rate, as estimated for 2003 through 2008 at the Area 3 RWMS, was 61.71 in. with a 95 percent UCL of 63.07 in. The CAS is located within the Aqueduct Mesa drainage basin, which drains south to Yucca Lake. The area is relatively flat with no nearby drainage channels. The nearest well is USGS WW-2, which is located approximately $0.67 \mathrm{mi}$ northeast of CAS 02-60-06. The depth to groundwater on August 21, 2008, was measured at 2,051.1 ft bgs (USGS, 2008). The soil at CAS 02-60-06 appears native and consists of sand to cobble-sized alluvium of various lithologies. Although the soil is native, the area has been disturbed due to the construction of numerous facilities in the surrounding area.

Release Information - The release at this CAS includes effluent discharged to the french drain. It is unknown whether the drain is perforated or open at the base. No additional information regarding release information has been identified.

Previous Investigation Results - Previous investigations of CAS 02-60-06 consist of a site visit and a geophysical survey. The french drain was not able to be identified during the site visit. A 3-in. steel pipe was found in the location where the french drain was identified in historical documentation. A geophysical survey of the pipe was completed, and a linear anomaly was found heading south from the pipe. Heavy vegetation surrounding not only the pipe but the entire building foundation limited the scope of the survey; therefore, the termination point of the linear anomaly was not found (Weston, 2007). It is not believed that the 3-in. pipe is the french drain, but it may be associated in some capacity. Removal of the vegetation surrounding the building foundation will be necessary to find the french drain. Because the configuration of the french drain is unknown, a site sketch has not been included.

\section{A.2.10 CAS 02-60-07, French Drain}

Corrective Action Site 02-60-07 consists of the soil potentially impacted by releases from the french drain. Figure A.2-10 shows the location of the CAS. 
Physical Setting and Operational History - Corrective Action Site 02-60-07 is located on Yucca Flat in Area 2. The CAS was identified adjacent to the former Electrical Supply Building in the Area 2 Camp, which was used to support LLNL drilling and construction activities. Documentation states that the french drain was used as a hand washing station, perhaps by personnel occupying the Electrical Supply Building. No other information has been identified discussing the use and details of the french drain.

Corrective Action Site 02-60-07 is located in the upper-central region of Area 2 in the Yucca Flat hydrographic region. Precipitation for the area from 2003 through 2008, as measured at the BJY Station, ranged from 4.33 to 10.43 in./yr, with a mean annual value of 6.73 in. (ARL/SORD, 2008). The mean annual PET rate, as estimated for 2003 through 2008 at the Area 3 RWMS, was 61.71 in. with a 95 percent UCL of 63.07 in. The CAS is located within the Aqueduct Mesa drainage basin, which drains south to Yucca Lake. The area is relatively flat with no nearby drainage channels. The nearest well is USGS WW-2, which is located approximately $0.69 \mathrm{mi}$ northeast of CAS 02-60-07. The depth to groundwater on August 21, 2008, was measured at 2,051.1 ft bgs (USGS, 2008). The soil at CAS 02-60-07 appears native and consists of sand to cobble-sized alluvium of various lithologies. Although the soil is native, the area has been disturbed due to the construction of numerous facilities in the surrounding area.

Release Information - The release at this CAS includes effluent discharged to the french drain. It is unknown whether the drain is perforated or open at the base. No additional information regarding release information has been identified.

Previous Investigation Results - Previous investigations of CAS 02-60-07 consist of a site visit and a geophysical survey. The french drain was not able to be identified during the site visit. A 4-in. steel pipe was found in the location where the french drain was identified in historical documentation. A geophysical survey of the pipe was completed, and no anomalies were identified. Heavy vegetation surrounding not only the pipe but the entire building foundation limited the scope of the survey. It is not believed that the 4-in. pipe is the french drain, but it may be associated in some capacity. Removal of the vegetation surrounding the building foundation will be necessary to find the french drain. Because the configuration of the french drain is unknown, a site sketch has not been included. 


\section{A.2.11 CAS 23-60-01, Mud Trap Drain and Outfall}

Corrective Action Site 23-60-01 consists of the soil potentially impacted by releases from the mud trap, grease rack, and outfall. Figure A.2-11 shows a site sketch of the CAS.

Physical Setting and Operational History - Corrective Action Site 23-60-01 is located in Mercury in Area 23. The CAS was identified adjacent to a wash shed in the former DNA Compound. The DNA Compound supported various DoD activities, including offices, maintenance buildings, gasoline pumps, and a vehicle wash area. The mud trap, grease rack, and outfall were added in 1958 to support the vehicle wash area. A trench drain present inside the wash shed collected effluent and discharged to the mud trap via piping. Overflow from the mud trap would then discharge to the outfall, which is located outside the compound fence line. No specific documentation was identified discussing the use of the grease rack, although it is assumed to have been used for vehicle maintenance.

Corrective Action Site 23-60-01 is located within the Mercury Valley drainage basin. Precipitation for the area from 2003 through 2008, as measured at the Mercury Gauging Station, ranged from 3.38 to 8.11 in. per year, with a mean annual value of 6.73 in. (ARL/SORD, 2008). The mean annual PET rate, as estimated for 2003 through 2008 at the Area 3 RWMS, was 61.71 in. with a 95 percent UCL of 63.07 in. Surface drainage and groundwater flow in the Mercury Valley is in the southwest direction. The outfall discharged to a wash south of the CAS that flows west. The nearest groundwater well to CAS 23-60-01 is USGS Well SM-23-1, an active well located approximately 1.5 mi southwest of the sites. The most recent recorded depth to the water table is approximately 1,164 ft bgs (USGS, 2008). The soil near the mud pit and grease rack consists of non-native pea gravel on the surface with a fine sandy silt below that is likely fill material. Near the outfall, the soil appears native and consists of sand to cobble-sized alluvium of various lithologies.

Release Information - The release at this CAS includes effluent discharged to the soil from the mud trap, grease, rack, and outfall. The mud trap is contained, so unless there has been a breach in the concrete encasement or piping or an overflow, there should not be a release associated with the mud trap. The outfall was designed to release to daylight, although the outfall currently is covered by soil. No containment exists below the grease rack; therefore, if vehicles were in place on the grease rack 


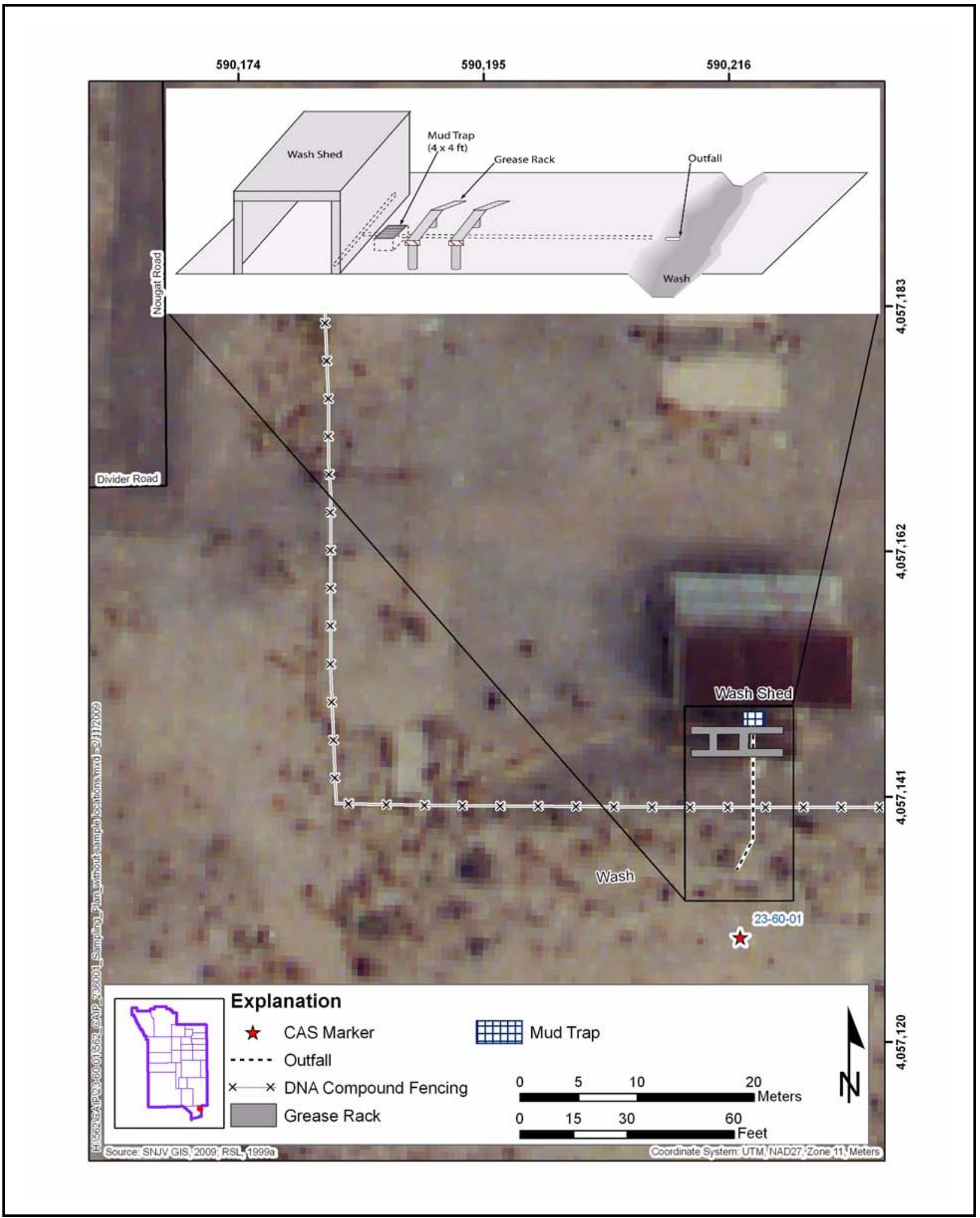

Figure A.2-11

Locations of CAS 23-60-01, Mud Trap Drain and Outfall 
and a leak or spill occurred, then there would have been a release to the soil. No staining is visible in the wash or below the grease rack.

Previous Investigation Results - Previous investigations of CAS 23-60-01 consist of a site visit and a geophysical survey. A concrete trench inside the wash shed drains to the mud trap via a 4-in. pipe. The mud trap is 4 by 4 by $4 \mathrm{ft}$, with 6 -in. thick concrete walls. Two pieces of metal grate cover the mud trap so rainwater can enter the trap. During the site visit, liquid was present in the trap, presumably due to recent heavy rainfall. The mud trap drains via piping to the outfall area located approximately $40 \mathrm{ft}$ south of the mud trap. The outfall originally opened up in a wash but has since been covered by soil erosion. The termination point of the outfall was determined through a geophysical survey (Weston, 2007).

\section{A.2.12 CAS 23-99-06, Grease Trap}

Corrective Action Site 23-99-06 consists of the soil potentially impacted by releases from the grease trap. Figure A.2-12 shows a site sketch of the CAS.

Physical Setting and Operational History - Corrective Action Site 23-99-06 is located in Mercury in Area 23. The CAS was identified adjacent to Building 109, a former commercial gas service station. The building is currently used as the Housing/Revenues Building. Before the building was converted to its current configuration, a grease pit and drywell inside the building drained to the grease trap located on the south side of Building 109. The grease trap then drained via piping to the active sewer system. Sometime in the mid-1980s, the grease pit and drywell were made inactive and filled with concrete so that discharge to the grease trap ceased. The grease trap was not filled in during the building renovation.

Corrective Action Site 23-99-06 is located within the Mercury Valley drainage basin. Precipitation for the area from 2003 through 2008, as measured at the Mercury Gauging Station, ranged from 3.38 to 8.11 in. per year, with a mean annual value of 6.73 in. (ARL/SORD, 2008). The mean annual PET rate, as estimated for 2003 through 2008 at the Area 3 RWMS, was 61.71 in. with a 95 percent UCL of 63.07 in. Surface drainage and groundwater flow in the Mercury Valley is in the southwest direction. No washes exist near CAS 23-99-06. The nearest groundwater well to CAS 23-99-06 is USGS Well SM-23-1, an active well located approximately $1.5 \mathrm{mi}$ southwest of the sites. The most 


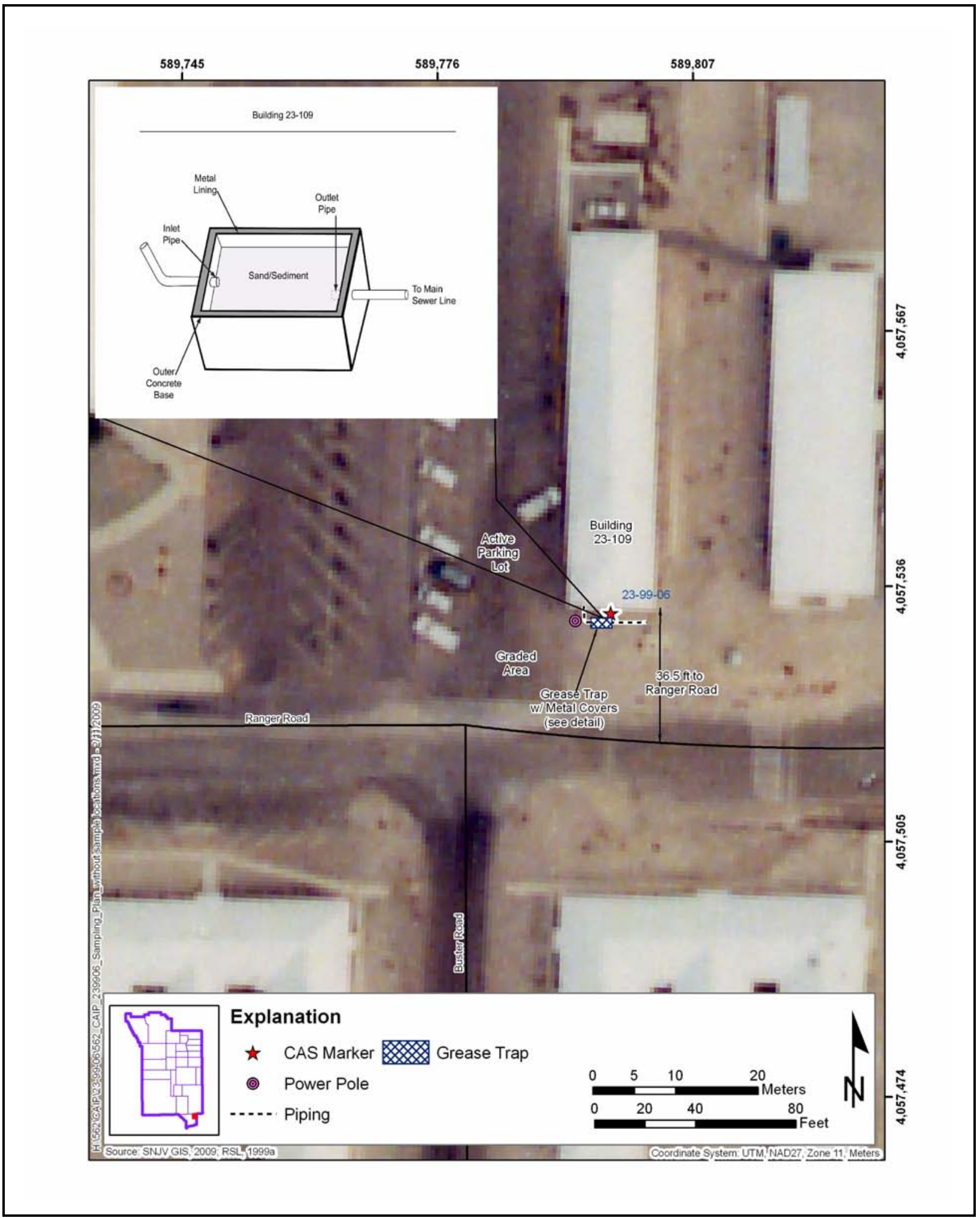

Figure A.2-12

Site Sketch of CAS 23-99-06, Grease Trap 
recent recorded depth to the water table is approximately 1,164 ft bgs (USGS, 2008). The soil consists of sand to cobble-sized alluvium of various lithologies and has been disturbed due to the CAS's location in an active area.

Release Information - The potential release at this CAS includes effluent discharged to the soil from the grease trap. The grease trap is contained so unless there has been a breach in the concrete encasement or piping or an overflow, there should not be a release associated with the grease trap.

Previous Investigation Results - Previous investigations of CAS 23-99-06 consist of a site visit. The grease trap is 5 by $3 \mathrm{ft}$, with 6 in.-thick concrete walls. The grease trap is completely covered by two heavy pieces of metal. The lids were removed to expose the grease trap's interior. The grease trap is partially filled with damp soil that has a hydrocarbon odor. The grease trap drains via piping to sewer system piping.

\section{A.2.13 CAS 25-60-04, Building 3123 Outfalls}

This CAS was added to CAU 562 after the DQO strategy was developed and agreed upon. However, this site consists of outfalls that were already present on the agreed upon CSM; therefore, no adjustments to the CSM was necessary.

Corrective Action Site 25-60-04 consists of the soil impacted by releases from the two outfalls. Figure A.2-13 shows a site sketch of the CAS.

Physical Setting and Operational History - Corrective Action Site 25-60-04 is located in the Reactor Control Point (RCP) in Area 23. The CAS was identified as being associated with Building 3123, Technical Services, which contained laboratory, shop, and office space. Two outfalls were identified, Drain A and Drain B. Drain A received effluent from floor drains, utility trench drains, and sinks present in the labs; some of the labs were named the Neutronics Lab, Radiation Lab, and Central Repair. Drain A was designed to extend $25 \mathrm{ft}$ west of the building and drain to daylight. One sink and one floor drain from a room with unknown use discharged to Drain B, which was designed to extend between 33.5 and $40 \mathrm{ft}$ south of the building and drain to daylight. Drains A and B consisted of 4-in. acid-resistant piping called Duriron. The building is currently being used for other purposes, and effluent was inadvertently being discharged to the outfalls. Drain A has been receiving effluent 


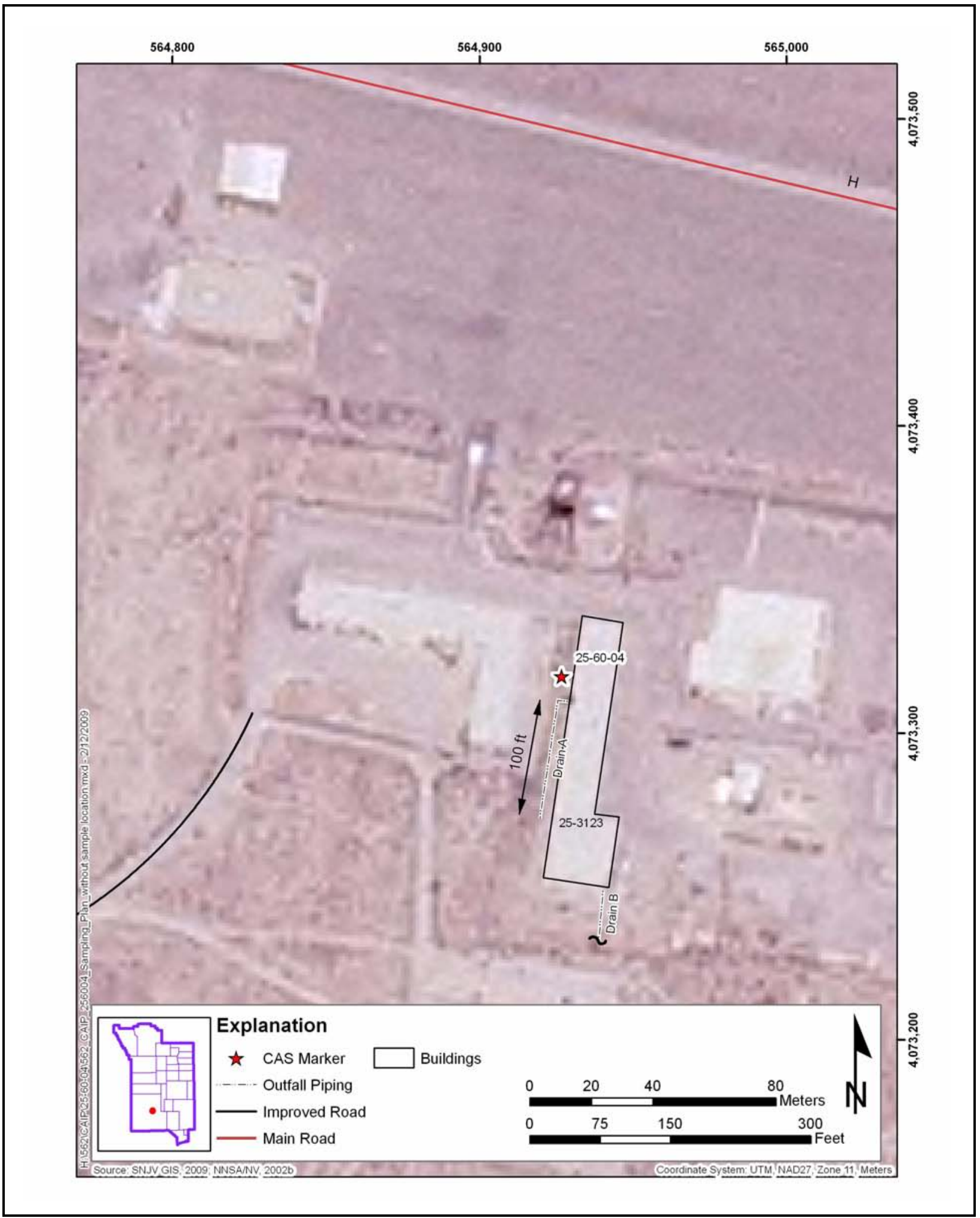

Figure A.2-13

Site Sketch of CAS 25-60-04, Building 3123 Outfalls 
from the main kitchen (located in the former laboratory area), while Drain B has been receiving effluent from a smaller kitchen area. Although the building remains active, the source of discharge to the outfalls has ceased and they are now inactive.

Corrective Action Site 25-60-04 is located in Area 25 within the Jackass Flats drainage basin. Precipitation for the area from 2003 through 2008, as measured at the Jackass Flats (4JA) Station, ranged from 3.99 to 11.04 in./yr, with a mean annual value of 7.74 in. (ARL/SORD, 2008). The mean annual PET rate, as estimated for 2003 through 2008 at the Area 3 RWMS, was 61.71 in. with a 95 percent UCL of 63.07 in. Area 25 (Jackass Flats) is an intermontane valley of the NTS bordered by highlands on all sides except for a large drainage outlet to the southwest. The nearest groundwater well to CAS 25-60-04 is the J-11 Water Well, which is located $1.5 \mathrm{mi}$ southwest. The most recent recorded depth to the water table is approximately 1,040 ft bgs (USGS, 2008). The soil at CAS 25-60-04 appears native and consists of sand to cobble-sized alluvium of various lithologies.

Release Information - The potential release at this CAS includes effluent discharged to the soil from the two outfalls. Both outfalls drained to the ground surface initially, and more recently, to subsurface soils.

Previous Investigation Results - Previous investigations of CAS 25-60-04 consist of a site visit and a camera survey. The original termination point for Drain A was identified by excavation to be about $25 \mathrm{ft}$ west of the building. An elbow has been added to the end of the pipe, and the pipe now terminates approximately $100 \mathrm{ft}$ south of the original termination point. The pipe is buried approximately $2 \mathrm{ft}$ bgs and a length of the pipe is covered by asphalt. Stained soil, which smelled heavily of kitchen grease, was evident at the opening of the outfall. The excavations remain open. An attempt was made to put a camera down Drain B to ascertain its configuration; however, the camera was not able to navigate the bend in the pipe due to the angle the pipe takes to the subsurface. No evidence exists of the pipe on the ground surface; therefore, the pipe may have been covered with soil or has been reconfigured. 


\section{A.3.0 Step 1 - State the Problem}

Step 1 of the DQO process defines the problem that requires study, identifies the planning team, and develops a conceptual model of the environmental hazard to be investigated.

The problem statement for CAU 562 is: "Existing information on the nature and extent of potential contamination is insufficient to evaluate and recommend corrective action alternatives for the CASs in CAU 562.”

\section{A.3.1 Planning Team Members}

The DQO planning team consists of representatives from NDEP, NNSA/NSO, SNJV, and NSTec. The DQO planning team met on December 11, 2008, for the DQO meeting. The primary decision makers are the NDEP and NNSA/NSO representatives.

\section{A.3.2 Conceptual Site Model}

The CSM is used to organize and communicate information about site characteristics. It reflects the best interpretation of available information at any point in time. The CSM is a primary vehicle for communicating assumptions about release mechanisms, potential migration pathways, or specific constraints. It provides a good summary of how and where contaminants are expected to move and what impacts such movement may have. It is the basis for assessing how contaminants could reach receptors both in the present and future. The CSM describes the most probable scenario for current conditions at each site and defines the assumptions that are the basis for identifying appropriate sampling strategy and data collection methods. Accurate CSMs are important as they serve as the basis for all subsequent inputs and decisions throughout the DQO process.

The CSM was developed for CAU 562 using information from the physical setting, potential contaminant sources, release information, historical background information, knowledge from similar sites, and physical and chemical properties of the potentially affected media and COPCs. 
The CSM consists of:

- Potential contaminant releases, including media subsequently affected.

- Release mechanisms (the conditions associated with the release).

- Potential contaminant source characteristics, including contaminants suspected to be present and contaminant-specific properties.

- Site characteristics, including physical, topographical, and meteorological information.

- Migration pathways and transport mechanisms that describe the potential for migration and where the contamination may be transported.

- The locations of points of exposure where individuals or populations may come in contact with a COC associated with a CAS.

- $\quad$ Routes of exposure where contaminants may enter the receptor.

If additional elements are identified during the investigation that are outside the scope of the CSM, the situation will be reviewed and a recommendation will be made as to how to proceed. In such cases, NDEP will be notified and given the opportunity to comment on, or concur with, the recommendation.

The applicability of the CSM to each CAS is summarized in Table A.3-1 and discussed below. Table A.3-1 provides information on CSM elements that will be used throughout the remaining steps of the DQO process. Figure A.3-1 represents site conditions applicable to the CSM. 
Table A.3-1

Conceptual Site Model Description of Elements for Each CAS in CAU 562

(Page 1 of 2)

\begin{tabular}{|c|c|c|c|c|c|c|c|c|c|c|c|c|}
\hline CAS Identifier & $\begin{array}{l}-1 \\
\dot{j} \\
\stackrel{1}{1} \\
\text { ปे }\end{array}$ & 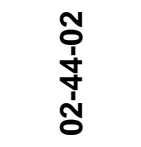 & 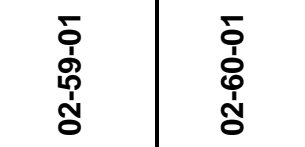 & $\begin{array}{l}\text { ণิ } \\
\text { రิ } \\
\stackrel{1}{0}\end{array}$ & 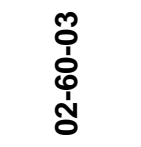 & $\begin{array}{l}\text { ঠ் } \\
\text { ర் } \\
\text { ป் }\end{array}$ & $\begin{array}{l}\text { ㅇ } \\
\text { ò } \\
\vdots \\
\text { ஸे }\end{array}$ & 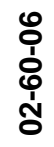 & $\begin{array}{l}\text { ○ } \\
\text { ò } \\
\text { ஸ் }\end{array}$ & 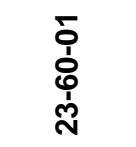 & 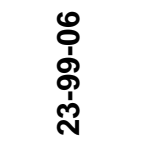 & $\begin{array}{l}\text { ச } \\
\text { ర் } \\
\text { ம் }\end{array}$ \\
\hline $\begin{array}{c}\text { CAS } \\
\text { Description }\end{array}$ & 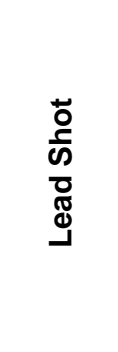 & 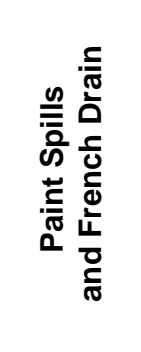 & 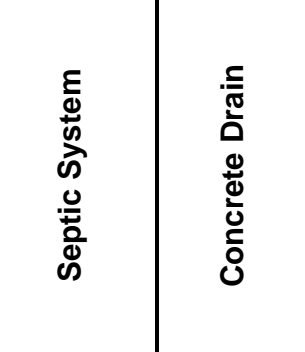 & 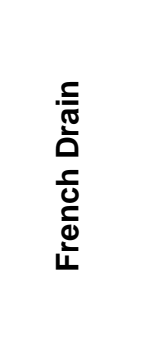 & 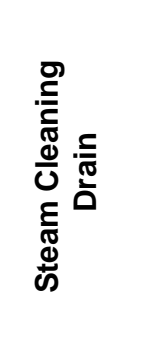 & 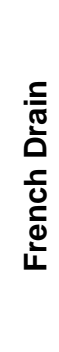 & 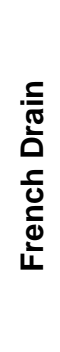 & 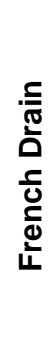 & 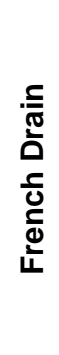 & 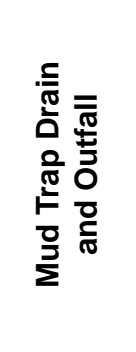 & 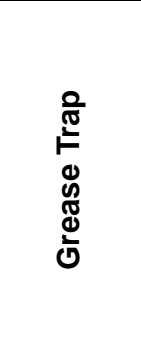 & 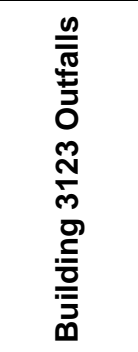 \\
\hline Site Status & \multicolumn{12}{|c|}{ Sites are inactive and/or abandoned } \\
\hline $\begin{array}{c}\text { Exposure } \\
\text { Scenario }\end{array}$ & \multicolumn{9}{|c|}{ Occasional Use Area } & \multicolumn{3}{|c|}{ Industrial Use Area } \\
\hline $\begin{array}{c}\text { Sources of } \\
\text { Potential Soil } \\
\text { Contamination }\end{array}$ & Shot & $\begin{array}{l}\text { Paint, } \\
\text { effluent, } \\
\text { spill }\end{array}$ & \multicolumn{7}{|c|}{ Effluent } & $\begin{array}{l}\text { Effluent, } \\
\text { spills }\end{array}$ & \multicolumn{2}{|c|}{ Effluent } \\
\hline $\begin{array}{c}\text { Location of } \\
\text { Contamination/ } \\
\text { Release Point }\end{array}$ & $\begin{array}{c}\text { Surface } \\
\text { soil at or } \\
\text { near } \\
\text { locations } \\
\text { of shot }\end{array}$ & $\begin{array}{l}\text { Surface } \\
\text { soil at or } \\
\text { near the } \\
\text { spill and } \\
\text { paint; } \\
\text { subsurface } \\
\text { soil below } \\
\text { the french } \\
\text { drain }\end{array}$ & $\begin{array}{l}\text { Subsurface soil below site } \\
\text { components }\end{array}$ & $\begin{array}{c}\text { Surface } \\
\text { soil at or } \\
\text { near the } \\
\text { elongated } \\
\text { drains; } \\
\text { subsurface } \\
\text { soil below } \\
\text { the french } \\
\quad \text { drain }\end{array}$ & $\begin{array}{l}\text { Surface } \\
\text { soil at or } \\
\text { near the } \\
\text { sump, } \\
\text { concrete } \\
\text { pad, and } \\
\text { outfall; } \\
\text { subsurface } \\
\text { soil below } \\
\text { the sump }\end{array}$ & \multicolumn{4}{|c|}{ Subsurface soil below the french drains } & $\begin{array}{l}\text { Surface } \\
\text { soil at or } \\
\text { near the } \\
\text { outfall and } \\
\text { grease } \\
\text { rack; } \\
\text { subsurface } \\
\text { soil below } \\
\text { the mud } \\
\text { trap }\end{array}$ & $\begin{array}{c}\text { Subsurface } \\
\text { soil below } \\
\text { the grease } \\
\text { trap }\end{array}$ & $\begin{array}{c}\text { Shallow } \\
\text { subsurface } \\
\text { and } \\
\text { subsurface } \\
\text { soil at the } \\
\text { outfall } \\
\text { termination } \\
\text { points }\end{array}$ \\
\hline $\begin{array}{c}\text { Amount } \\
\text { Released }\end{array}$ & \multicolumn{12}{|c|}{ Unknown } \\
\hline
\end{tabular}


Table A.3-1

Page A-36 of A-85

Conceptual Site Model Description of Elements for Each CAS in CAU 562

(Page 2 of 2)

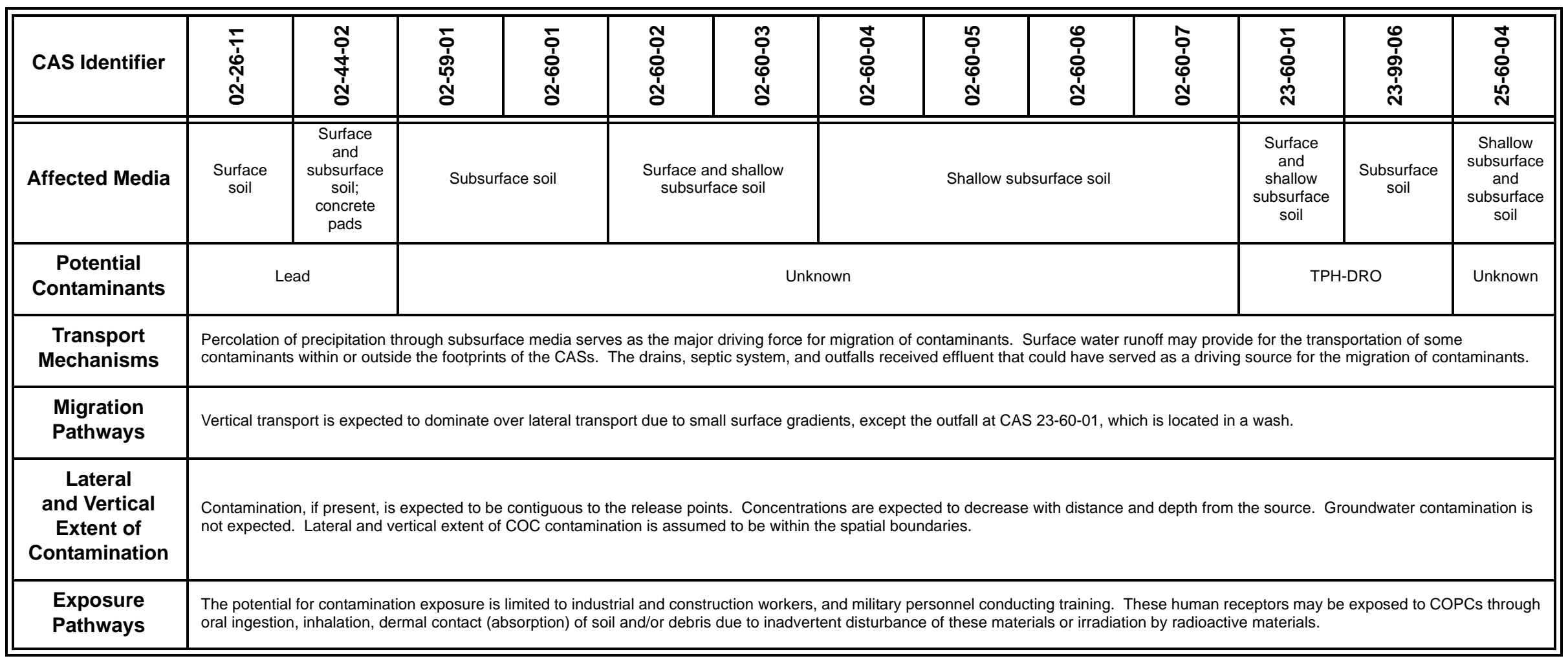


K:Doc-prod1562IFiguresiWorking FilesICAU 562_CSM_L.ai

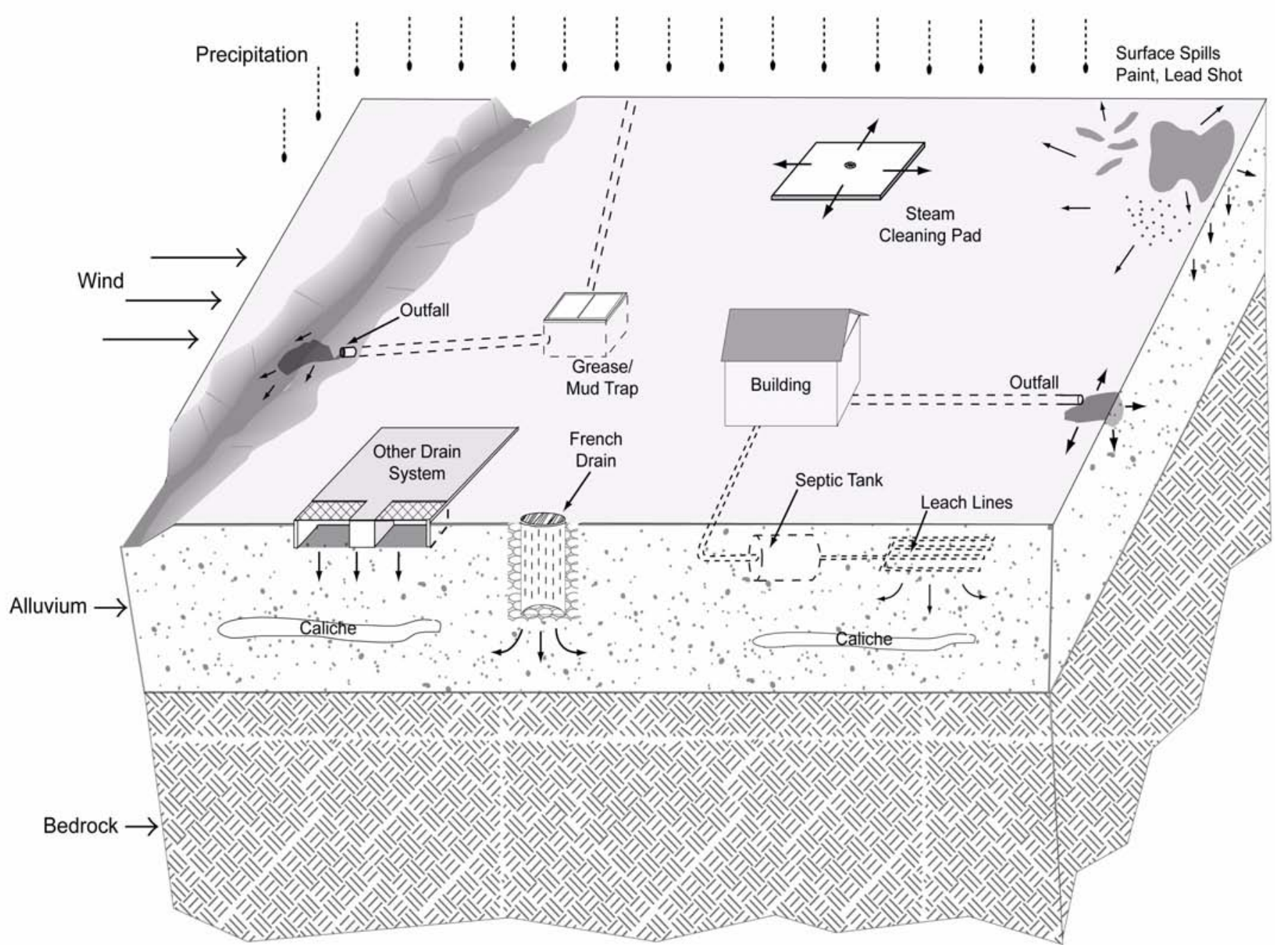

Figure A.3-1

Conceptual Site Model for CAU 562 


\section{A.3.2.1 Contaminant Release}

The most likely locations of the contamination and releases to the environment are the soils directly below or adjacent to the CSM's surface and subsurface components (i.e., lead shot; septic tank; drains; sump; associated underground piping, including outfalls; grease/mud traps; and leachfield). The CSM accounts for potential releases resulting from overflow to the ground surface from system components (e.g., drains, sump, drains, and traps) and surface spills. Any contaminants migrating from CASs, regardless of physical or chemical characteristics, are expected to exist at interfaces, and in the soil adjacent to spills and disposal features in lateral and vertical directions. Concentrations are expected to decrease with lateral and vertical distance from the source.

\section{A.3.2.2 Potential Contaminants}

The COPCs were identified during the planning process through the review of site history, process knowledge, personal interviews, past investigation efforts (where available), and inferred activities associated with the CASs. Because complete information regarding activities performed at the CAU 562 sites is not available, contaminants detected at similar NTS sites were included in the contaminant lists to reduce uncertainty. The list of COPCs is intended to encompass all of the contaminants that could potentially be present at each CAS. The COPCs applicable to Decision I environmental samples from each of the CASs of CAU 562 are defined as the constituents reported from the analytical methods presented in Table A.3-2. Pesticides and herbicides have been included in the analytical suite for CAS 02-59-01, as these have been found in other septic system investigations on the NTS. Available information on all other CASs suggest that pesticides were not stored, mixed, or handled at the associated facilities. The CASs within CAU 562 that are identified as french drains are associated with former shops (e.g., paint and electrical) that have no history of storing or mixing pesticides or herbicides. Antimony has been included in the analytical suite for CAS 02-26-11, because it has been historically used as a hardener for lead shot. Because CAS 25-60-04 is located near the Reactor Control Point of Area 25, and has been identified as a potential beryllium site, beryllium has been added to the analytical suite for this CAS.

During the review of site history documentation, process knowledge information, personal interviews, past investigation efforts (where available), and inferred activities associated with the CASs, some of the COPCs were identified as targeted contaminants at specific CASs. Targeted 
Table A.3-2

\section{Analytical Program ${ }^{\mathrm{a}}$}

\begin{tabular}{|c|c|c|c|c|c|c|c|c|c|c|c|c|c|}
\hline Analyses & 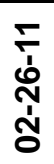 & 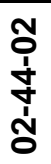 & 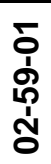 & 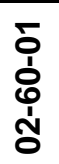 & 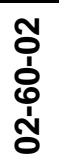 & 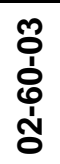 & 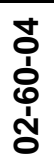 & 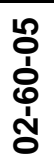 & $\begin{array}{l}0 \\
0 \\
\grave{1} \\
\dot{1} \\
\stackrel{1}{0}\end{array}$ & 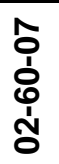 & 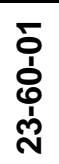 & $\begin{array}{l}\text { ஜ } \\
\text { ò } \\
\text { ò } \\
\text { ஸे }\end{array}$ & 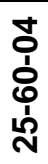 \\
\hline \multicolumn{14}{|c|}{ Organic COPCs } \\
\hline TPH-DRO & $\bar{x}$ & $\bar{x}$ & $x$ & $\bar{x}$ & $x$ & $\bar{x}$ & $\bar{x}$ & $\bar{x}$ & $x$ & $x$ & $\bar{x}$ & $\bar{x}$ & $\bar{x}$ \\
\hline PCBs & $x$ & $x$ & $x$ & $x$ & $x$ & $x$ & $x$ & $x$ & $x$ & $x$ & $x$ & $x$ & $x$ \\
\hline SVOCs & $x$ & $x$ & $x$ & $x$ & $x$ & $x$ & $x$ & $x$ & $x$ & $x$ & $x$ & $x$ & $x$ \\
\hline VOCs & $x$ & $x$ & $x$ & $x$ & $x$ & $x$ & $x$ & $x$ & $x$ & $x$ & $x$ & $x$ & $x$ \\
\hline Pesticides & -- & -- & $x$ & -- & -- & -- & -- & -- & -- & -- & -- & -- & -- \\
\hline Herbicides & -- & -- & $x$ & -- & -- & -- & -- & -- & -- & -- & -- & -- & -- \\
\hline \multicolumn{14}{|c|}{ Inorganic COPCs } \\
\hline RCRA Metals & $\bar{x}$ & $\bar{x}$ & $\mathrm{x}$ & $\mathbf{X}$ & $\mathrm{X}$ & $\mathrm{X}$ & $\bar{x}$ & $\mathrm{x}$ & $\mathbf{x}$ & $x$ & $x$ & $\mathrm{x}$ & $\bar{x}$ \\
\hline Beryllium & -- & -- & -- & -- & -- & -- & -- & -- & -- & -- & -- & -- & $x$ \\
\hline Antimony & $x$ & -- & -- & -- & -- & -- & -- & -- & -- & -- & -- & -- & -- \\
\hline \multicolumn{14}{|c|}{ Radionuclide COPCs } \\
\hline Gamma Spectroscopy $^{b}$ & $\bar{x}$ & $\bar{x}$ & $\mathrm{X}$ & $\mathbf{x}$ & $\mathbf{x}$ & $\mathbf{x}$ & $\mathrm{X}$ & $\mathbf{x}$ & $\mathbf{x}$ & $\mathbf{x}$ & $\mathbf{x}$ & $\mathrm{x}$ & $\bar{x}$ \\
\hline
\end{tabular}

aThe COPCs are the constituents reported from the analytical methods listed.

${ }^{\mathrm{b}}$ Results of gamma analysis will be used to determine whether further isotopic analysis is warranted.

$\mathrm{X}=$ Required analytical method

$--=$ Not required 
contaminants are those COPCs for which available site and process information suggests that they may be reasonably suspected to be present at a given CAS. The targeted contaminants are required to meet more stringent completeness criteria than other COPCs, thus providing greater protection against a decision error (see Section 6.2.6). Targeted contaminants for each CAU 562 CAS are identified in Table A.3-3.

Table A.3-3

Targeted Contaminants for CAU 562

\begin{tabular}{|c|c|c|}
\hline CAS & $\begin{array}{c}\text { Chemical Targeted } \\
\text { Contaminant(s) }\end{array}$ & $\begin{array}{c}\text { Radiological Targeted } \\
\text { Contaminant(s) }\end{array}$ \\
\hline $02-26-11$ & Lead & None \\
\hline $02-44-02$ & Lead & None \\
\hline 02-59-01 & None & None \\
\hline 02-60-01 & None & None \\
\hline $02-60-02$ & None & None \\
\hline $02-60-03$ & None & None \\
\hline $02-60-04$ & None & None \\
\hline $02-60-05$ & None & None \\
\hline $02-60-06$ & None & None \\
\hline $02-60-07$ & None & None \\
\hline 23-60-01 & $\begin{array}{l}\text { TPH-DRO (hazardous } \\
\text { constituents of diesel) }\end{array}$ & None \\
\hline 23-99-06 & $\begin{array}{l}\text { TPH-DRO (hazardous } \\
\text { constituents of diesel) }\end{array}$ & None \\
\hline 25-60-04 & None & None \\
\hline
\end{tabular}

\section{A.3.2.3 Contaminant Characteristics}

Contaminant characteristics include, but are not limited to, solubility, density, and adsorption potential. In general, contaminants with low solubility, high affinity for media, and high density can be expected to be found relatively close to release points. Contaminants with small particle size, high solubility, low density, and/or low affinity for media are found further from release points or in low areas where evaporation or ponding will concentrate dissolved contaminants. 


\section{A.3.2.4 Site Characteristics}

Site characteristics are defined by the interaction of physical, topographical, and meteorological attributes and properties. Physical properties include permeability, porosity, hydraulic conductivity, degree of saturation, sorting, chemical composition, and organic content. Topographical and meteorological properties and attributes include slope stability, precipitation frequency and amounts, precipitation runoff pathways, drainage channels and ephemeral streams, and evapotranspiration potential.

\section{A.3.2.5 Migration Pathways and Transport Mechanisms}

Migration pathways include the lateral migration of potential contaminants across surface soils/sediments and vertical migration of potential contaminants through subsurface soils. Contaminants released into a wash, as in the case at CAS 23-60-01, are subject to a much higher potential for lateral transport than contaminants released to other surface areas that are not in drainage areas. Washes are generally dry but are subject to infrequent, potentially intense, stormwater flows. These stormwater flow events provide an intermittent mechanism for both vertical and horizontal transport of contaminants. Contaminated sediments entrained by these stormwater events would be carried by the streamflow to locations where the flowing water loses energy and the sediments drop out. These locations are readily identifiable by hydrologists as sedimentation areas. Surface water from the Area 2 CASs drain to Yucca Lake, while the Area 23 surface water drains to Amargosa Valley.

Infiltration and percolation of precipitation serves as a driving force for downward migration of contaminants. However, due to high PET (annual PET at the Area 3 RWMS has been estimated at 62.6 in. [Shott et al., 1997]) and limited precipitation for this region (6.35 in./yr [ARL/SORD, 2008]), percolation of infiltrated precipitation at the NTS does not provide a significant mechanism for vertical migration of contaminants to groundwater (DOE/NV, 1992).

\section{A.3.2.6 Exposure Scenarios}

Human receptors may be exposed to COPCs through oral ingestion, inhalation, dermal contact (absorption) of soil or debris due to inadvertent disturbance of these materials or irradiation by radioactive materials. The land-use and exposure scenarios for the CAU 562 CASs are listed in 
Table A.3-4. These are based on NTS current and future land use. The Area 2 CASs are at remote locations without any site improvements and where no regular work is performed. The possibility still exists, however, that site workers could occupy these locations on an occasional and temporary basis such as a military exercise. Therefore, these sites are classified as occasional work areas.

The Area 23 and 25 CASs are in populated areas where site improvement can take place and where regular work is performed. Therefore, these sites are classified as industrial use areas.

Table A.3-4

Land-Use and Exposure Scenarios

\begin{tabular}{|c|c|c|}
\hline CAS & Record of Decision Land-Use Zone & Exposure Scenario \\
\hline $\begin{array}{l}02-26-11 \\
02-44-02 \\
02-59-01 \\
02-60-01 \\
02-60-02 \\
02-60-03 \\
02-60-04 \\
02-60-05 \\
02-60-06 \\
02-60-07\end{array}$ & $\begin{array}{l}\text { Nuclear and High Explosives Test } \\
\text { This area is designated within the Nuclear Test Zone for } \\
\text { additional underground nuclear weapons tests and } \\
\text { outdoor high explosive tests. This zone includes } \\
\text { compatible defense and nondefense research, } \\
\text { development, and testing activities. }\end{array}$ & $\begin{array}{l}\text { Occasional Use Area } \\
\text { Worker will be exposed to the site } \\
\text { occasionally (up to } 80 \text { hours per year for } \\
5 \text { years). Site structures are not present for } \\
\text { shelter and comfort of the worker. }\end{array}$ \\
\hline $\begin{array}{l}23-60-01 \\
23-99-06\end{array}$ & $\begin{array}{l}\text { Reserved (within NTS area) } \\
\text { This area is includes land and facilities that provide } \\
\text { widespread flexible support for diverse short-term testing } \\
\text { and experimentation. The reserved zone is also used for } \\
\text { short-duration exercises and training such as nuclear } \\
\text { emergency response, and Federal Radiological } \\
\text { Monitoring and Assessment Canter training and DoD } \\
\text { land-navigation exercise and training. }\end{array}$ & \multirow{2}{*}{$\begin{array}{l}\text { Industrial Area } \\
\text { Worker will be exposed to the site full time } \\
\text { ( } 225 \text { days per year, } 10 \text { hours per day for } \\
25 \text { years). Active powered buildings with } \\
\text { toilets are present at the site. }\end{array}$} \\
\hline $25-60-04$ & $\begin{array}{l}\text { Research Test and Experiment } \\
\text { The Research Test and Experiment Zone is designated } \\
\text { for small-scale research and development projects and } \\
\text { demonstrations; pilot projects; outdoor tests; and } \\
\text { experiments for development, QA, or reliability of } \\
\text { material and equipment under controlled conditions. } \\
\text { This includes compatible nondefense research, } \\
\text { development, and testing projects and activities. }\end{array}$ & \\
\hline
\end{tabular}




\section{A.4.0 Step 2 - Identify the Goal of the Study}

Step 2 of the DQO process states how environmental data will be used in meeting objectives and solving the problem, identifies study questions or decision statement(s), and considers alternative outcomes or actions that can occur upon answering the question(s).

\section{A.4.1 Decision Statements}

The Decision I statement is: "Is any COC present in environmental media within the CAS?” For judgmental sampling design, any analytical result for a COPC above the FAL will result in that COPC being designated as a COC. A COC may also be defined as a contaminant that, in combination with other like contaminants, is determined to jointly pose an unacceptable risk based on a multiple constituent analysis (NNSA/NSO, 2006). If a COC is detected, then Decision II must be resolved.

The Decision II statement is: "If a COC is present, is sufficient information available to evaluate potential corrective action alternatives?” Sufficient information is defined to include:

- The lateral and vertical extent of COC contamination

- The information needed to determine potential remediation waste types

- The information needed to evaluate the feasibility of remediation alternatives

A corrective action will be determined for any site containing a COC. The evaluation of the need for corrective action will include the potential for wastes that are present at a site to cause the future contamination of site environmental media if the wastes were to be released. To evaluate the potential for a future release from source material introducing a COC to the surrounding environmental media, the following conservative assumptions were made:

- Any current containment of wastes would fail at some point, and the contents would be released to the surrounding media.

- For non-liquid wastes, the resulting concentration of contaminants in the surrounding media would be equal to the concentration of contaminants in the waste.

- For liquid wastes, the resulting concentration of contaminants in the surrounding soil will be calculated based on the concentration of contaminants in the waste and the liquid holding capacity of the soil. 
If sufficient information is not available to evaluate potential corrective action alternatives, then site conditions will be re-evaluated and additional samples will be collected (as long as the scope of the investigation is not exceeded and any CSM assumption has not been shown to be incorrect).

\section{A.4.2 Alternative Actions to the Decisions}

This section identifies actions that may be taken to solve the problem depending on the possible outcomes of the investigation.

\section{A.4.2.1 Alternative Actions to Decision I}

If no COC associated with a release from the CAS is detected, then further assessment of the CAS is not required. If a COC associated with a release from the CAS is detected, then the extent of COC contamination will be determined and additional information required to evaluate potential corrective action alternatives will be collected.

\section{A.4.2.2 Alternative Actions to Decision II}

If sufficient information is available to evaluate potential corrective action alternatives, then further assessment of the CAS is not required. If sufficient information is not available to evaluate potential corrective action alternatives, then additional samples will be collected. 


\section{A.5.0 Step 3 - Identify Information Inputs}

Step 3 of the DQO process identifies the information needed, determines sources for information, and identifies sampling and analysis methods that will allow reliable comparisons with FALs.

\section{A.5.1 Information Needs}

To resolve Decision I (determine whether a COC is present at a given CAS), samples need to be collected and analyzed following these two criteria:

- $\quad$ Samples must be collected in areas most likely to contain a COC (judgmental sampling).

- The analytical suite selected must be sufficient to identify any COCs present in the samples.

To resolve Decision II (determine whether sufficient information is available to evaluate potential corrective action alternatives at each CAS), samples need to be collected and analyzed to meet the following criteria:

- Samples must be collected in areas contiguous to the contamination but where contaminant concentrations are below FALs.

- Samples of the waste or environmental media must provide sufficient information to determine potential remediation waste types.

- Samples of the waste in site components (e.g., septic tank, grease and mud traps) must provide sufficient information to determine whether they contain PSM.

- Appropriate samples must be submitted to evaluate the feasibility of remediation alternatives (e.g., geotechnical data if construction or evaluation of barriers is considered).

- The analytical suites selected must be sufficient to detect contaminants at concentrations equal to or less than their corresponding FALs.

\section{A.5.2 Sources of Information}

Information to satisfy Decision I and Decision II will be generated by collecting environmental samples using grab sampling, hand auguring, direct push, backhoe excavation, or other appropriate sampling methods. These samples will be submitted to analytical laboratories meeting the quality criteria stipulated in the Industrial Sites QAPP (NNSA/NV, 2002a). Only validated data from 
analytical laboratories will be used to make DQO decisions. Sample collection and handling activities will follow standard procedures.

\section{A.5.2.1 Sample Locations}

Design of the sampling approaches for the CAU 562 CASs must ensure that the data collected are sufficient for selection of the corrective action alternatives (EPA, 2002). To meet this objective, the samples collected from each site should be from locations that most likely contain a COC, if present.

Decision I sample locations at all of the CAU 562 CASs will be determined based upon the likelihood of the soil containing a COC, if present at the CAS. These locations will be selected based on field-screening techniques, biasing factors, the CSM, and existing information. Analytical suites for Decision I samples will include all COPCs identified in Table A.3-2.

Field-survey techniques may be used to select appropriate sampling locations and field-screening techniques may be used to provide semiquantitative data that can be used to comparatively select samples to be submitted for laboratory analyses from several screening locations. Field screening may also be used for health and safety monitoring and to assist in making certain health and safety decisions. The following methods may be used to select analytical samples at CAU 562:

- Walkover surface area radiological surveys - A radiological survey instrument will be used over approximately 100 percent of the CAS boundaries in Areas 2 and 25, as permitted by terrain and field conditions, to detect locations of elevated radioactivity.

- Alpha and beta/gamma radiation - A radiological survey instrument will be used.

- Gamma-emitting radionuclides - A radiological dose rate measurement instrument will be used.

Biasing factors may also be used to select samples to be submitted for laboratory analyses based on existing site information and site conditions discovered during the investigation. The following factors will also be considered in selecting locations for analytical samples at CAU 562:

- Documented process knowledge on source and location of release (e.g., volume of release). 
- Stains: Any spot or area on the soil surface that may indicate the presence of a potentially hazardous liquid. Typically, stains indicate an organic liquid such as an oil has reached the soil, and may have spread out vertically and horizontally.

- Elevated radiation: Any location identified during radiological surveys that had alpha/beta/gamma levels significantly higher than surrounding background soil.

- Geophysical anomalies: Any geophysical survey results that are not consistent with the natural surroundings (e.g., buried concrete or metal).

- Debris: Materials that contain, or contained, hazardous or radioactive substances.

- Lithology: Locations where variations in lithology (soil or rock) indicate that different conditions or materials exist.

- Preselected areas based on process knowledge of the site: Locations for which evidence such as historical photographs, experience from previous investigations, or interviewee's input exists that a release of hazardous or radioactive substances may have occurred.

- Experience and data from investigations of similar sites.

- Visual indicators such as discoloration, textural discontinuities, disturbance of native soils, or any other indication of potential contamination.

- Odor.

- Other biasing factors: Factors not previously defined for the CAI that become evident once the investigation of the site is under way.

Decision II sample step-out locations will be selected based on the CSM, biasing factors, and existing data. Analytical suites will include those parameters that exceeded FALs (i.e., COCs) in prior samples. Biasing factors to support Decision II sample locations include Decision I biasing factors plus available analytical results.

\section{A.5.2.2 Analytical Methods}

Analytical methods are available to provide the data needed to resolve the decision statements. The analytical methods and laboratory requirements (e.g., detection limits, precision, and accuracy) are provided in Tables 3-4 and 3-5. 


\section{A.6.0 Step 4 - Define the Boundaries of the Study}

Step 4 of the DQO process defines the target population of interest and its relevant spatial boundaries, specifies temporal and other practical constraints associated with sample/data collection, and defines the sampling units on which decisions or estimates will be made.

\section{A.6.1 Target Populations of Interest}

The population of interest to resolve Decision I ("Is any COC present in environmental media within the CAS?”) is at any location within the site that is contaminated with any contaminant above a FAL. The populations of interest to resolve Decision II ("If a COC is present, is sufficient information available to evaluate potential corrective action alternatives?”) are:

- Each one of a set of locations bounding contamination in lateral and vertical directions.

- Potential remediation waste.

- Environmental media where natural attenuation or biodegradation or construction/evaluation of barriers is considered.

\section{A.6.2 Spatial Boundaries}

Spatial boundaries are the maximum lateral and vertical extent of expected contamination at each CAS, as shown in Table A.6-1. Contamination found beyond these boundaries may indicate a flaw in the CSM and may require re-evaluation of the CSM before the investigation could continue. Each CAS is considered geographically independent, and intrusive activities are not intended to extend into the boundaries of neighboring CASs.

\section{A.6.3 Practical Constraints}

Practical constraints such as military activities at the NTS, weather (i.e., high winds, rain, lightning, extreme heat), utilities, threatened or endangered animal and plants, unstable or steep terrain, and/or access restrictions may affect the ability to investigate this site. Three CASs in CAU 562 have practical constraints. At CAS 23-60-01, the location of the mud trap between the wash shed and the 
Table A.6-1

Spatial Boundaries of CAU 562 CASs

\begin{tabular}{|c|c|}
\hline CAS & Spatial Boundaries \\
\hline 02-26-11 & The footprint of the shot plus a 50-ft lateral buffer; $15 \mathrm{ft}$ bgs vertically. \\
\hline 02-44-02 & $\begin{array}{l}\text { The area containing the paint and historical spills as well as the french drain plus a } 50 \text {-ft lateral buffer; } \\
15 \mathrm{ft} \text { bgs vertically of the spills and the base of the french drain. }\end{array}$ \\
\hline 02-59-01 & The footprint of the septic system plus a 50 -ft lateral buffer; $20 \mathrm{ft}$ bgs vertically. \\
\hline 02-60-01 & $\begin{array}{l}\text { The footprint of the concrete drain plus a } 50 \text {-ft lateral buffer; } 15 \mathrm{ft} \text { bgs vertically of the base of the } \\
\text { concrete drain. }\end{array}$ \\
\hline 02-60-02 & $\begin{array}{l}\text { The footprint of the french drain and elongated drains plus a } 50 \text {-ft lateral buffer; } 15 \mathrm{ft} \mathrm{bgs} \mathrm{vertically} \mathrm{of} \\
\text { the base of the drains. }\end{array}$ \\
\hline 02-60-03 & $\begin{array}{l}\text { The footprint of the steam cleaning sump and outfall plus a } 50 \text { - } \mathrm{ft} \text { lateral buffer; } 15 \mathrm{ft} \text { bgs vertically of the } \\
\text { base of the sump and outfall. }\end{array}$ \\
\hline 02-60-04 & The footprint of the french drain plus a $50-\mathrm{ft}$ lateral buffer; $15 \mathrm{ft}$ bgs vertically of the base of the drain. \\
\hline 02-60-05 & The footprint of the french drain plus a 50 - $\mathrm{ft}$ lateral buffer; $15 \mathrm{ft}$ bgs vertically of the base of the drain. \\
\hline 02-60-06 & The footprint of the french drain plus a 50 - $\mathrm{ft}$ lateral buffer; $15 \mathrm{ft}$ bgs vertically of the base of the drain. \\
\hline 02-60-07 & The footprint of the french drain plus a 50 - $\mathrm{ft}$ lateral buffer; $15 \mathrm{ft}$ bgs vertically of the base of the drain. \\
\hline 23-60-01 & $\begin{array}{l}\text { The footprint of the mud trap and outfall plus a 50-ft lateral buffer for the mud trap and a } 500-\mathrm{ft} \text { lateral } \\
\text { buffer for the outfall located in the wash; } 15 \text { bgs vertically of the base of the mud trap and outfall. }\end{array}$ \\
\hline 23-99-06 & $\begin{array}{l}\text { The footprint of the grease trap plus a } 50 \text { - } \mathrm{ft} \text { lateral buffer; } 15 \mathrm{ft} \text { bgs vertically of the base of the } \\
\text { grease trap. }\end{array}$ \\
\hline $25-60-04$ & The footprint of the two outfalls plus a $50-\mathrm{ft}$ lateral buffer; $15 \mathrm{ft}$ bgs vertically from the base of the outfall. \\
\hline
\end{tabular}

grease rack restricts the use of heavy equipment. Both CASs 23-99-06 and 25-60-04 are associated with active buildings that have numerous active utilities within the site boundary.

\section{A.6.4 Define the Sampling Units}

The scale of decision making in Decision I is defined as the CAS or CAS components. Any COC detected at any location within the CAS components will cause the determination that the CAS is contaminated and needs further evaluation. The scale of decision making for Decision II is defined as a contiguous area contaminated with any COC originating from the CAS or the CAS components. Resolution of Decision II requires this contiguous area to be bounded laterally and vertically. 


\section{A.7.0 Step 5 - Develop the Analytic Approach}

Step 5 of the DQO process specifies appropriate population parameters for making decisions, defines action levels, and generates an "If ... then ... else" decision rule that involves it.

\section{A.7.1 Population Parameters}

For judgmental sampling results, the population parameter is the observed concentration of each contaminant from each individual analytical sample. Each sample result will be compared to the FALs to determine the appropriate resolution to Decision I and Decision II. For Decision I, a single sample result for any contaminant exceeding a FAL would cause a determination that a COC is present within the CAS.

The Decision II population parameter is an individual analytical result from a bounding sample. For Decision II, a single bounding sample result for any contaminant exceeding a FAL would cause a determination that the contamination is not bounded.

\section{A.7.2 Action Levels}

The PALs presented in this section are to be used for site screening purposes. They are not necessarily intended to be used as cleanup action levels or FALs. However, they are useful in screening out contaminants that are not present in sufficient concentrations to warrant further evaluation and, therefore, streamline the consideration of remedial alternatives. The RBCA process used to establish FALs is described in the Industrial Sites Project Establishment of Final Action Levels (NNSA/NSO, 2006). This process conforms with NAC Section 445A.227, which lists the requirements for sites with soil contamination (NAC, 2006a). For the evaluation of corrective actions, NAC Section 445A.22705 (NAC, 2006b) requires the use of ASTM Method E 1739-95 (ASTM, 1995) to "conduct an evaluation of the site, based on the risk it poses to public health and the environment, to determine the necessary remediation standards (i.e., FALs) or to establish that corrective action is not necessary.” 
This RBCA process defines three tiers (or levels) of evaluation involving increasingly sophisticated analyses:

- Tier 1 evaluation - Sample results from source areas (highest concentrations) are compared to action levels based on generic (non-site-specific) conditions (i.e., the PALs established in the CAIP). The FALs may then be established as the Tier 1 action levels, or the FALs may be calculated using a Tier 2 evaluation.

- Tier 2 evaluation - Conducted by calculating Tier 2 SSTLs using site-specific information as inputs to the same or similar methodology used to calculate Tier 1 action levels. The Tier 2 SSTLs are then compared to individual sample results from reasonable points of exposure (as opposed to the source areas as is done in Tier 1) on a point-by-point basis. Total TPH concentrations will not be used for risk-based decisions under Tier 2 or Tier 3 . Rather, the individual chemicals of concern will be compared to the SSTLs.

- Tier 3 evaluation - Conducted by calculating Tier 3 SSTLs on the basis of more sophisticated risk analyses using methodologies described in Method E 1739-95 that consider site-, pathway-, and receptor-specific parameters.

The comparison of laboratory results to FALs and the evaluation of potential corrective actions will be included in the CADD for CAU 562. The FALs will be defined (along with the basis for their definition) in the CADD for CAU 562.

\section{A.7.2.1 Chemical PALs}

Except as noted herein, the chemical PALs are defined as the Region 9: Superfund, Preliminary Remediation Goals, Screening Levels for Chemical Contaminants in industrial soils (EPA, 2008). Background concentrations for RCRA metals will be used instead of PRGs when natural background concentrations exceed the PRG, as is often the case with arsenic on the NTS. Background is considered the average concentration plus two standard deviations of the average concentration for sediment samples collected by the Nevada Bureau of Mines and Geology throughout the Nevada Test and Training Range (formerly the Nellis Air Force Range) (NBMG, 1998; Moore, 1999). For detected chemical COPCs without established PRGs, the protocol used by the EPA Region 9 in establishing PRGs (or similar) will be used to establish PALs. If used, this process will be documented in the CADD for CAU 562.

\section{A.7.2.2 Total Petroleum Hydrocarbon PALs}

The PAL for TPH is $100 \mathrm{mg} / \mathrm{kg}$ as listed in NAC 445A.2272 (NAC, 2006c). 


\section{A.7.2.3 Radionuclide PALs}

The PALs for radiological contaminants (other than tritium) are based on the NCRP Report No. 129 recommended screening limits for construction, commercial, industrial land-use scenarios (NCRP, 1999) scaled to 25-mrem/yr dose constraint (Murphy, 2004), and the generic guidelines for residual concentration of radionuclides in DOE Order 5400.5 (DOE, 1993).

\section{A.7.3 Decision Rules}

The decision rules applicable to both Decision I and Decision II are:

- If COC contamination is inconsistent with the CSM or extends beyond the spatial boundaries identified in Section A.6.2, then work will be suspended and the investigation strategy will be reconsidered, else the decision will be to continue sampling to define the extent.

The decision rules for Decision I are:

- If the population parameter of any COPC in the Decision I population of interest (defined in Step 4) exceeds the corresponding FAL, then that contaminant is identified as a COC, and Decision II samples will be collected, else no further investigation is needed for that COPC in that population.

- If a COC exists at any CAS, then a corrective action will be determined, else no further action will be necessary.

- If a waste is present that, if released, has the potential to cause the future contamination of site environmental media, then a corrective action will be determined, else no further action will be necessary.

The decision rules for Decision II are:

- If the population parameter (the observed concentration of any COC) in the Decision II population of interest (defined in Step 4) exceeds the corresponding FAL in any bounding direction, then additional samples will be collected to complete the Decision II evaluation, else the extent of the COC contamination has been defined.

- If valid analytical results are available for the waste characterization samples defined in Section A.9.0, then the decision will be that sufficient information exists to determine potential remediation waste types and evaluate the feasibility of remediation alternatives, else collect additional waste characterization samples. 


\section{A.8.0 Step 6 - Specify Performance or Acceptance Criteria}

Step 6 of the DQO process defines the decision hypotheses, specifies controls against false rejection and false acceptance decision errors, examines consequences of making incorrect decisions from the test, and places acceptable limits on the likelihood of making decision errors.

\section{A.8.1 Decision Hypotheses}

The baseline condition (i.e., null hypothesis) and alternative condition for Decision I are:

- $\quad$ Baseline condition - A COC is present.

- Alternative condition - A COC is not present.

The baseline condition (i.e., null hypothesis) and alternative condition for Decision II are as follows:

- $\quad$ Baseline condition - The extent of a COC has not been defined.

- Alternative condition - The extent of a COC has been defined.

Decisions and/or criteria have false negative or false positive errors associated with their determination. The impact of these decision errors and the methods that will be used to control these errors are discussed in the following subsections. In general terms, confidence in DQO decisions based on judgmental sampling results will be established qualitatively by:

- The development and concurrence of CSMs (based on process knowledge) by stakeholder participants during the DQO process

- Validity testing of CSMs based on investigation results

- Evaluation of the data quality based on DQI parameters

\section{A.8.2 False Negative Decision Error}

The false negative decision error would mean deciding that a COC is not present when it actually is (Decision I), or deciding that the extent of a COC has been defined when it has not (Decision II). In both cases, the potential consequence is an increased risk to human health and environment. 


\section{A.8.2.1 False Negative Decision Error for Judgmental Sampling}

In judgmental sampling, the selection of the number and location of samples is based on knowledge of the feature or condition under investigation and on professional judgment (EPA, 2002).

Judgmental sampling conclusions about the target population depend upon the validity and accuracy of professional judgment.

The false negative decision error (where consequences are more severe) for judgmental sampling designs is controlled by meeting these criteria:

- For Decision I, having a high degree of confidence that the sample locations selected will identify COCs if present anywhere within the CAS. For Decision II, having a high degree of confidence that the sample locations selected will identify the extent of COCs.

- Having a high degree of confidence that analyses conducted will be sufficient to detect any COCs present in the samples.

- Having a high degree of confidence that the dataset is of sufficient quality and completeness.

To satisfy the first criterion, Decision I samples must be collected in areas most likely to be contaminated by COCs (supplemented by random samples where appropriate). Decision II samples must be collected in areas that represent the lateral and vertical extent of contamination (above FALs). The following characteristics must be considered to control decision errors for the first criterion:

- Source and location of release

- Chemical nature and fate properties

- Physical transport pathways and properties

- Hydrologic drivers

These characteristics were considered during the development of the CSMs and selection of sampling locations. The field-screening methods and biasing factors listed in Section A.5.2.1 will be used to further ensure that appropriate sampling locations are selected to meet these criteria. Radiological survey instruments and field-screening equipment will be calibrated and checked in accordance with the manufacturer's instructions and approved procedures. The CADD for CAU 562 will present an assessment on the DQI of representativeness that samples were collected from those locations that best represent the populations of interest as defined in Section A.6.1. 
To satisfy the second criterion, Decision I samples will be analyzed for the chemical and radiological parameters listed in Section 3.2. Decision II samples will be analyzed for those chemical and radiological parameters that identified unbounded COCs. The DQI of sensitivity will be assessed for all analytical results to ensure that all sample analyses had measurement sensitivities (detection limits) that were less than or equal to the corresponding FALs. If this criterion is not achieved, the affected data will be assessed (for usability and potential impacts on meeting site characterization objectives) in the CADD for CAU 562.

To satisfy the third criterion, the entire dataset, as well as individual sample results, will be assessed against the DQIs of precision, accuracy, comparability, and completeness as defined in the Industrial Sites QAPP (NNSA/NV, 2002a) and in Section 6.2.2. The DQIs of precision and accuracy will be used to assess overall analytical method performance as well as to assess the need to potentially “flag” (qualify) individual contaminant results when corresponding QC sample results are not within the established control limits for precision and accuracy. Data qualified as estimated for reasons of precision or accuracy may be considered to meet the constituent performance criteria based on an assessment of the data. The DQI for completeness will be assessed to ensure that all data needs identified in the DQO have been met. The DQI of comparability will be assessed to ensure that all analytical methods used are equivalent to standard EPA methods so that results will be comparable to regulatory action levels that have been established using those procedures. Strict adherence to established procedures and QA/QC protocol protects against false negatives. Site-specific DQIs are discussed in more detail in Section 6.2.2.

To provide information for the assessment of the DQIs of precision and accuracy, the following QC samples will be collected as required by the Industrial Sites QAPP (NNSA/NV, 2002a):

- Field duplicates (minimum of 1 per matrix per 20 environmental samples)

- Laboratory QC samples (minimum of 1 per matrix per 20 environmental samples or 1 per CAS per matrix, if less than 20 collected)

\section{A.8.3 False Positive Decision Error}

The false positive decision error would mean deciding that a COC is present when it is not, or a COC is unbounded when it is not, resulting in increased costs for unnecessary sampling and analysis. 
False positive results are typically attributed to laboratory and/or sampling/handling errors that could cause cross contamination. To control against cross contamination, decontamination of sampling equipment will be conducted according to established and approved procedures, and only clean sample containers will be used. To determine whether a false positive analytical result may have occurred, the following QC samples will be collected as required by the Industrial Sites QAPP (NNSA/NV, 2002a):

- Trip blanks (one per sample cooler containing VOC environmental samples)

- Equipment blanks (one per sampling event)

- Source blanks (one per uncharacterized source lot)

- Field blanks (three at the Area 2 CASs [many of these CASs are directly adjacent to one another] and one at each of the remaining CASs in Areas 23 and 25) 


\section{A.9.0 Step 7 - Develop the Plan for Obtaining Data}

Step 7 of the DQO process selects and documents a design that will yield data that will best achieve performance or acceptance criteria. A judgmental sampling scheme will be implemented to select sample locations and evaluate analytical results for CAU 562. Sections A.9.1 through A.9.2 contain general information about collecting Decision I and Decision II samples under a judgmental sampling design, while the subsequent sections provide CAS-specific sampling activities, including proposed sample locations. Environmental sample results will be compared to FALs to determine the need for corrective action. Potential source material sample results will be evaluated against the PSM criteria (Section 3.4) to determine the need for corrective action.

\section{A.9.1 Decision I Sampling}

A judgmental sampling design will be implemented for all of the CASs in CAU 562. Because individual sample results, rather than an average concentration, will be used to compare to FALs at the CASs undergoing judgmental sampling, statistical methods to generate site characteristics will not be used. Adequate representativeness of the entire target population may not be a requirement to developing a sampling design. If good prior information is available on the target site of interest, then the sampling may be designed to collect samples only from areas suspected to have the highest concentration levels on the target site. If the observed concentrations from these samples are below the action level, then a decision can be made that the site contains safe levels of the contaminant without the samples being truly representative of the entire area (EPA, 2006).

All sample locations will be selected to satisfy the DQI of representativeness in that samples collected from selected locations will best represent the populations of interest as defined in Section A.6.1. To meet this criterion for judgmentally sampled sites, a biased sampling strategy will be used for Decision I samples to target areas with the highest potential for contamination, if it is present anywhere in the CAS. Sample locations will be determined based on process knowledge, previously acquired data, or the field-screening and biasing factors listed in Section A.5.2.1. If biasing factors are present in soils below locations where Decision I samples were removed, additional Decision I soil samples will be collected at depth intervals selected by the Site Supervisor; depth intervals will be based on biasing factors to a depth where the biasing factors are no longer present. The Site 
Supervisor has the discretion to modify the judgmental sample locations, but only if the modified locations meet the decision needs and criteria stipulated in this DQO.

\section{A.9.2 Decision II Sampling}

To meet the DQI of representativeness for Decision II samples (that Decision II sample locations represent the population of interest as defined in Section A.6.1), judgmental sampling locations at each CAS will be selected based on the outer boundary sample locations where COCs were detected, the CSM, and other field-screening and biasing factors listed in Section A.5.2. In general, sample locations will be arranged in a triangular pattern around the Decision I location or area at distances based on site conditions, process knowledge, and biasing factors. If COCs extend beyond the initial step-outs, Decision II samples will be collected from incremental step-outs. Initial step-outs will be at least as deep as the vertical extent of contamination defined at the Decision I location and the depth of the incremental step-outs will be based on the deepest contamination observed at all locations. A clean sample (i.e., COCs less than FALs) collected from each step-out direction (lateral or vertical) will define extent of contamination in that direction. The Site Supervisor may modify the number, location, and spacing of step-outs as warranted by site conditions.

\section{A.9.3 CAS 02-26-11, Lead Shot}

At CAS 02-26-11, the area containing shot will be investigated. The area containing the shot has been estimated as 15,500 square feet. The shot is scattered throughout the site; however, the shot is not uniformly distributed, and some areas have a higher density of shot than other areas. Two surface (0.0 to $0.5 \mathrm{ft}$ bgs) samples, which will include the shot, will be collected from two locations: one area with a high concentration of rusted shot and one area with a high concentration of non-rusted shot. These samples will also be used to determine potential waste types. The surface samples will be collected in a manner that will be representative of surface material (i.e., without removing the shot) to provide information on the volume of potential waste. At each of these sample locations, a bounding sample will be collected at the 1.0 to $1.5 \mathrm{ft}$ bgs interval or at a deeper interval if biasing factors are present (e.g., shot). Directly adjacent to each of the two sample locations, additional bounding samples with 2 -in. lifts will be collected. The sample depths will be as follows: 0.0 to $2.0 \mathrm{in}$., 2.0 to $4.0 \mathrm{in}$., and 4.0 to $6.0 \mathrm{in}$. Shot will be removed from the these samples. The subsurface 
soil samples will be collected with the shot removed to provide information on the contaminants that may have leached from the shot.

A visual survey will be conducted to determine the lateral boundary of the site. A surface ( 0.0 to $0.5 \mathrm{ft}$ bgs) sample will be collected on each side, depending on the shape of the boundary (e.g., one surface sample from each side of the boundary, if the shape of the boundary is a square).

Proposed Decision I sample locations have not yet been selected for CAS 02-26-11. An example of the sampling strategy and site boundary is shown on Figure A.9-1. 


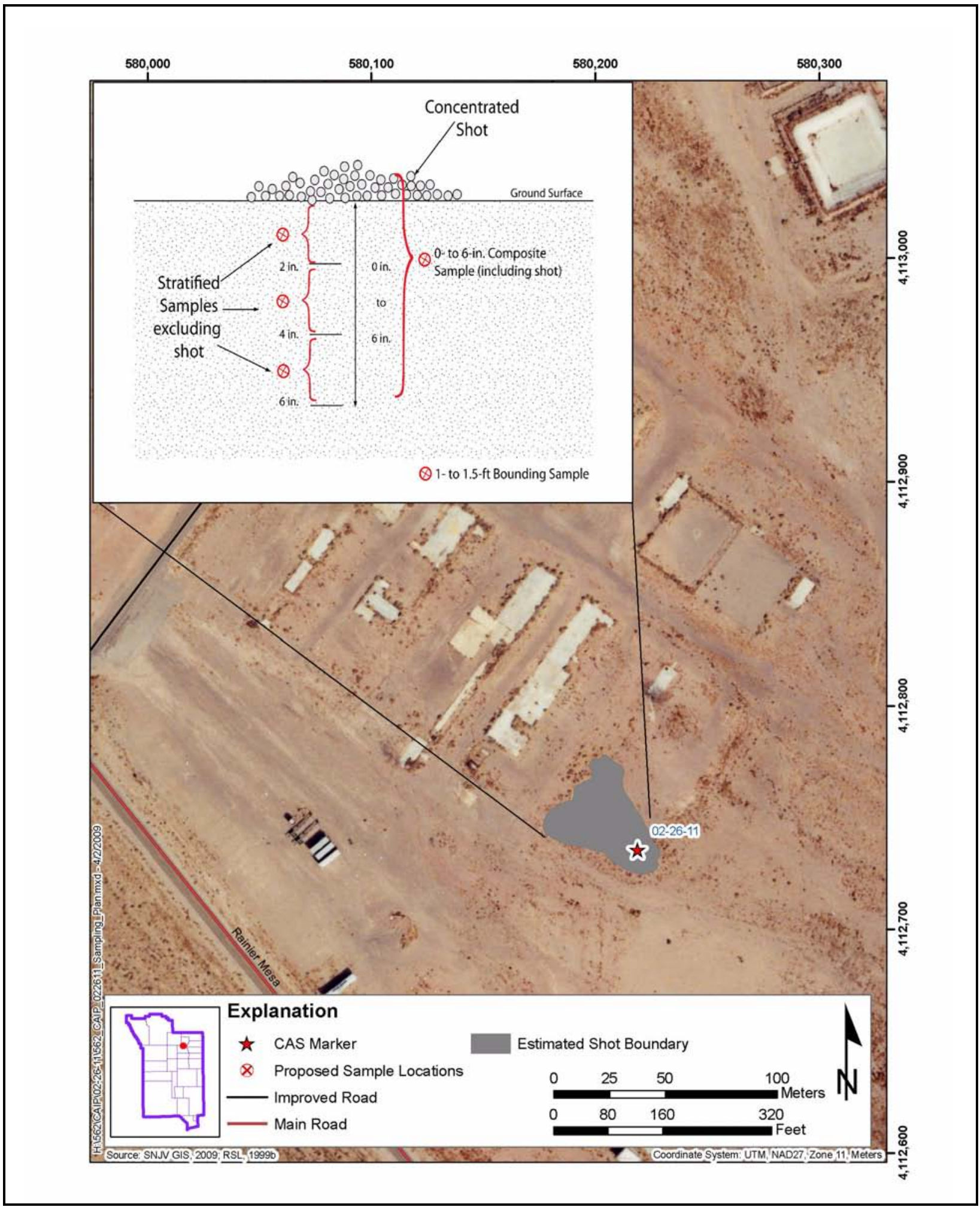

Figure A.9-1

Example Sampling Strategy at CAS 02-26-11, Lead Shot 


\section{A.9.4 CAS 02-44-02, Paint Spills and French Drain}

At CAS 02-44-02, the following features will be investigated:

French Drain - One sample will be collected from the lowest point from the interior of the french drain. Another sample will be collected at the native interface below the base of the drain. The samples will be accessed using a backhoe or similar equipment, and collected using a scoop and pan. The pipe present within the french drain will either be excavated during sampling or traced to the source. If biasing factors are encountered during the excavation or pipe tracing, additional samples will be collected at locations selected by the Site Supervisor.

Paint Spills - Two PSM samples of the paint located on the foundation of the former Painters Shed and Paint Storage Rack will be collected. Environmental sample results will be compared to FALs to determine the need for corrective action. Potential source material sample results will be evaluated against the PSM criteria listed in Section 3.4 to determine the need for corrective action. Two environmental samples ( 0.0 to $0.5 \mathrm{ft}$ and 1.0 to $1.5 \mathrm{ft}$ bgs) will be collected from the paint spill location on the soil northeast of the Paint Storage Rack. Three surface (0.0 to $0.5 \mathrm{ft}$ bgs) samples will be collected from each of the remaining sides (northwest, southeast, and southwest) of the Paint Storage Rack. Additionally, two surface ( 0.0 to $0.5 \mathrm{ft}$ bgs) samples will be collected from the northeastern and southwestern sides of the former Painters Shed. Additional samples will be collected if other biasing factors are identified.

Historical Spill - Two samples ( 0.0 to $0.5 \mathrm{ft}$ and 1.0 to $1.5 \mathrm{ft}$ bgs) will be collected from the historical spill located on the southeastern side of the former Painters Shed. The exact location will be determined using GPS coordinates provided in the document that first identified the spill (REECo, 1995). The sample will be collected using a scoop and pan. Additional samples will be collected if other biasing factors are identified.

Proposed Decision I sample locations are shown in Figure A.9-2. 


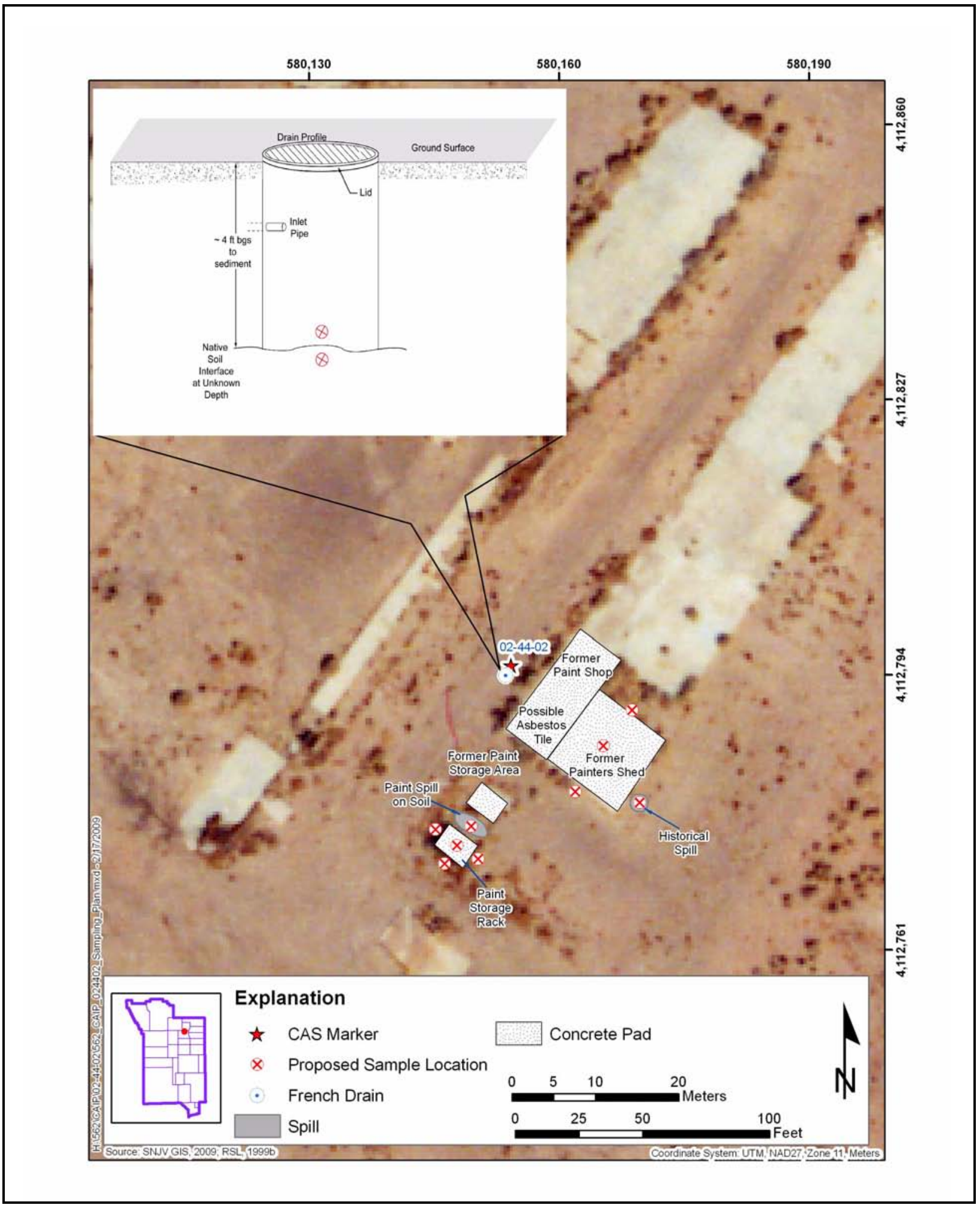

Figure A.9-2

Proposed Sample Locations at CAS 02-44-02, Paint Spills and French Drain 


\section{A.9.5 CAS 02-59-01, Septic System}

At CAS 02-59-01, the following features will be investigated:

Septic Tank - A sample will be collected for each phase of material present in any compartment within the septic tank and distribution box, if present. The samples will be collected using the most appropriate method for the material being collected (e.g., composite liquid waste sampler [COLIWASA] for liquid, extended scoop for sludge). Sampling outside the tank will include two samples from below the inlet and outlet pipe connections. Another two samples will be collected from each end of the base of the tank; these sample locations will be altered if biasing factors are encountered. If a distribution box is present, samples will be collected from below the influent and effluent piping at the base of the distribution box. These samples will be accessed using a backhoe or similar equipment, and collected using a grab sampling technique.

Leachfield - Six samples will be collected from the proximal and distal ends of the outer and center leachlines. The samples will be accessed using a backhoe or similar equipment, and collected using a grab sampling technique.

If COCs are identified in the septic system, then the piping associated with the septic tank and leach field will be video surveyed to identify breaches, if present. If breaches are identified, Decision II samples will be collected as appropriate.

Proposed Decision I sample locations are shown in Figure A.9-3. 


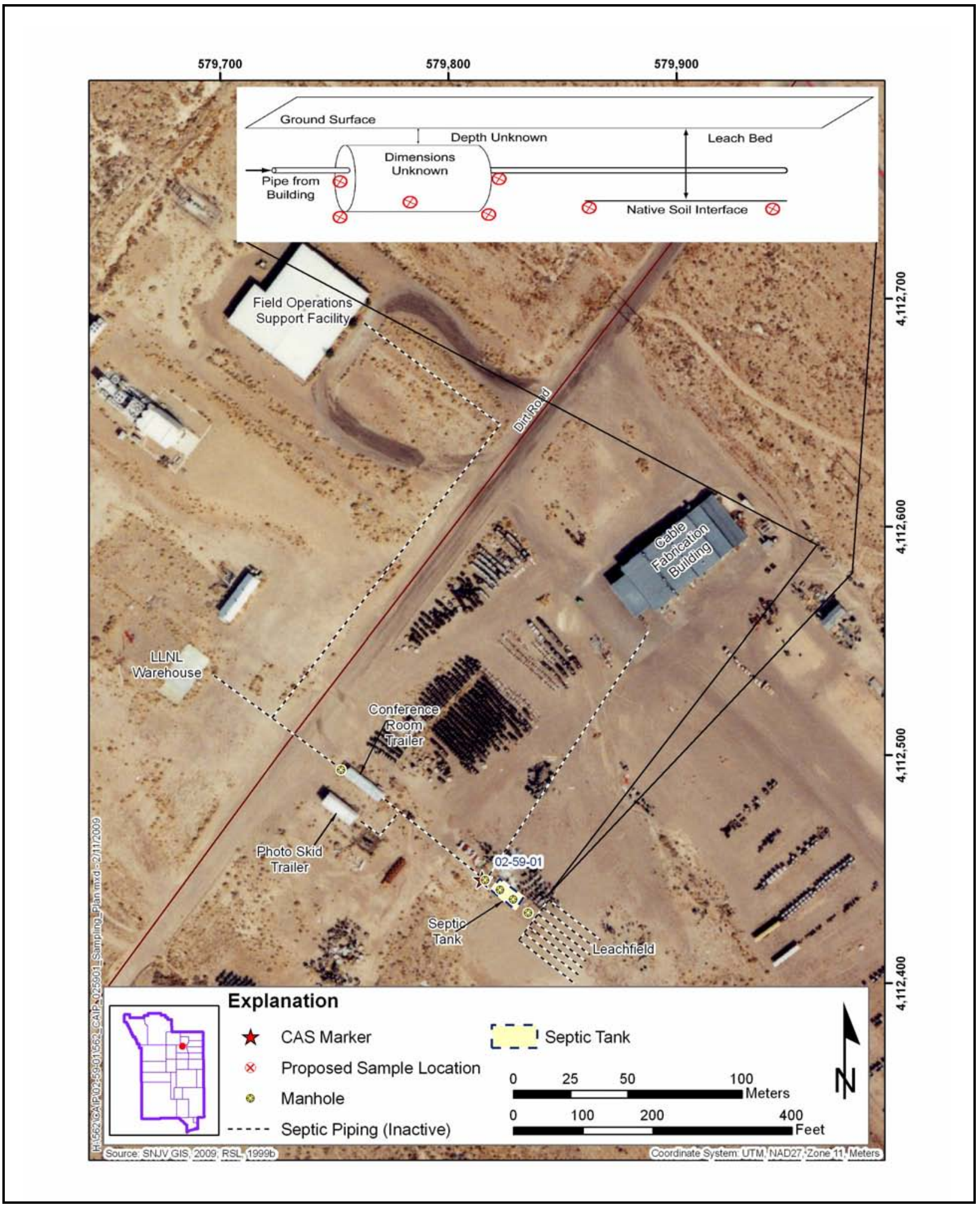

Figure A.9-3

Proposed Sample Locations at CAS 02-59-01, Septic System 


\section{A.9.6 CAS 02-60-01, Concrete Drain}

At CAS 02-60-01, the concrete drain and surrounding soil will be sampled. One sample will be collected from the lowest point of the interior of the concrete drain. Another sample will be collected from below the base of the concrete drain at the native soil interface. Because the drain has been backfilled with native soil, the interior will need to be excavated either by using a backhoe with a narrow bucket or hand excavation (e.g., using shovels). If biasing factors are identified during excavation, additional samples will be collected. The base of the drain will be accessed using the backhoe or similar equipment. Samples will be collected using a grab sampling technique.

Excavation will be completed near the outside of the drain to determine the source of the two anomalies identified during a geophysical survey. It is anticipated that the anomalies represent shallow subsurface metal debris and are not of environmental concern. Therefore, if there is no indication of an environmental release associated with the debris, no sampling is required. Upon excavation, if a feature is present that could have resulted in an environmental release (e.g., piping), a sampling strategy will be implemented that is typical to that type of feature.

Proposed Decision I sample locations are shown in Figure A.9-4. 


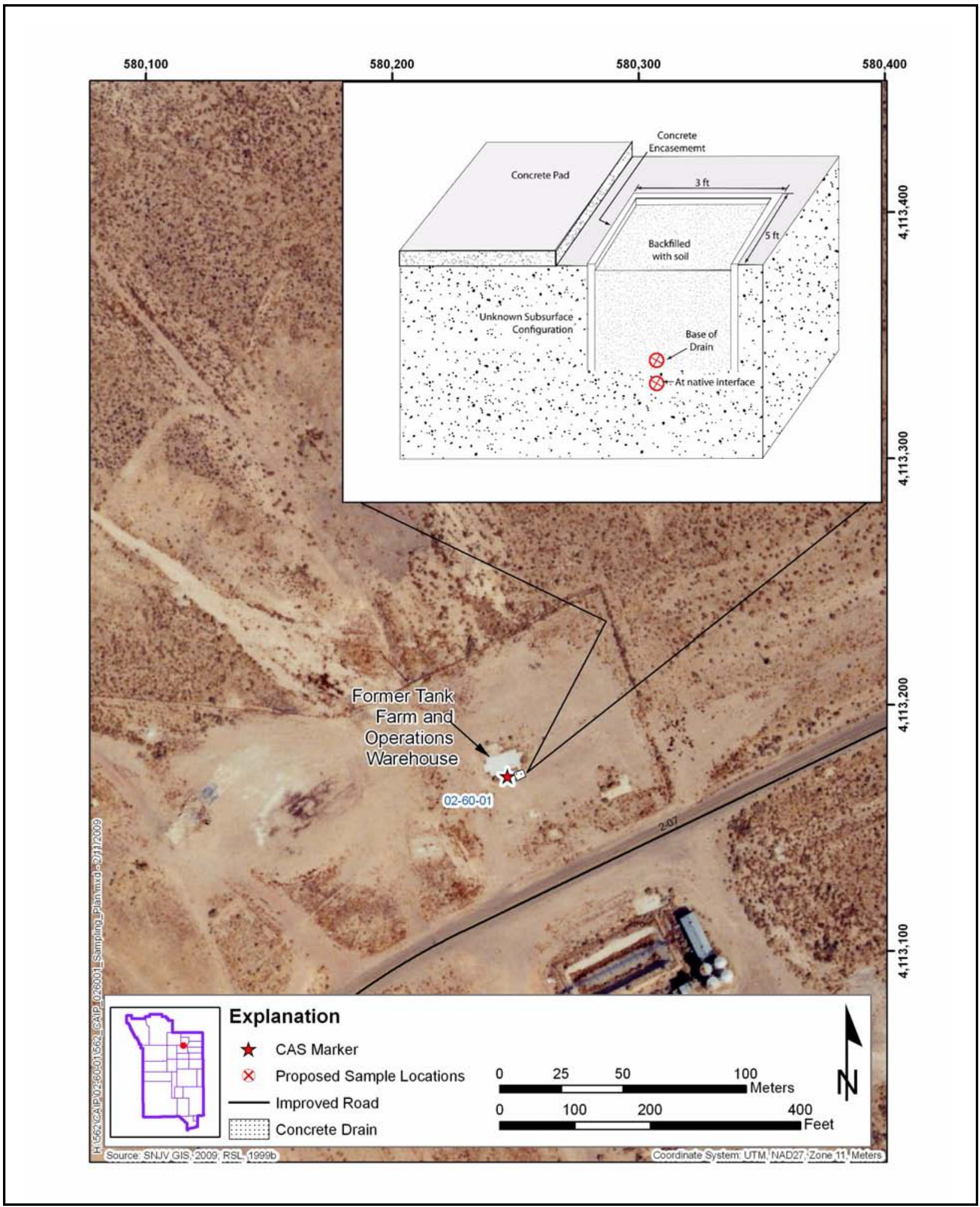

Figure A.9-4

Proposed Sample Locations at CAS 02-60-01, Concrete Drain 


\section{A.9.7 CAS 02-60-02, French Drain}

At CAS 02-60-02, the following features will be investigated:

French Drain - One sample will be collected from the lowest point from the interior of the french drain. Another sample will be collected at the native interface below the base of the drain. The samples will be accessed using a backhoe or similar equipment, and collected using a grab sampling technique. If biasing factors are encountered during the excavation, additional samples will be collected at locations selected by the Site Supervisor.

Elongated Drains - Two samples will be collected of the sediment from within each of the drains. Additionally, two samples will be collected from below the drains at the native soil interface. If biasing factors are identified, samples will be collected from locations selected by the Site Supervisor. Because the drains are shallow, the samples can be collected with hand sampling tools. If the native soil interface below the drains cannot be accessed by hand excavation (e.g., hand auger), a backhoe or similar equipment may be used.

Proposed Decision I sample locations are shown in Figure A.9-5. 


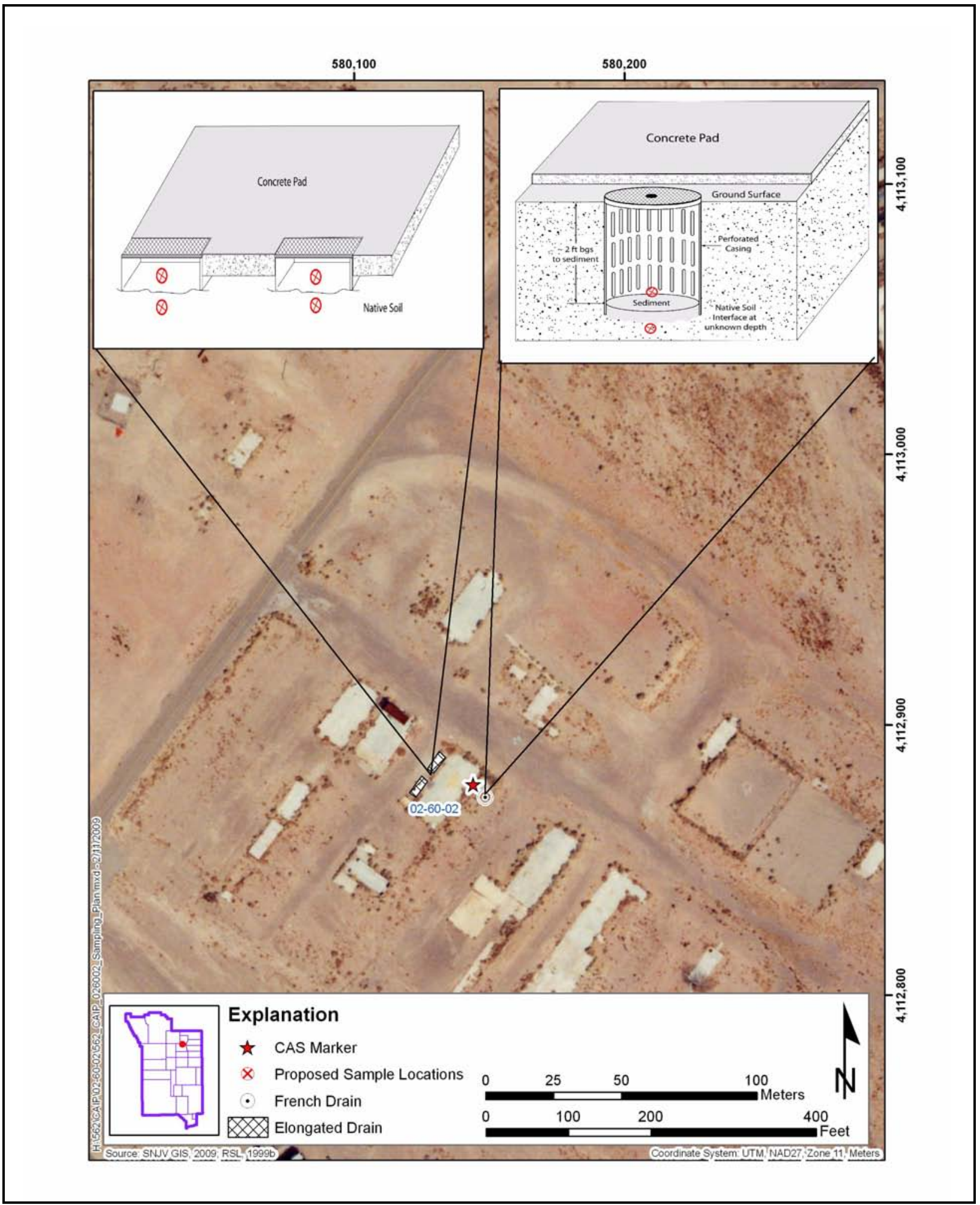

Figure A.9-5

Proposed Sample Locations at CAS 02-60-02, French Drain 


\section{A.9.8 CAS 02-60-03, Steam Cleaning Drain}

At CAS 02-60-03, the following features will be investigated:

Steam Cleaning Sump - One sample will be collected of the surface material present inside the steam cleaning sump. Another sample will be collected at the native soil interface below the material that has collected in or at the bottom of the sump. The grate will be removed and the samples will be accessed using a backhoe or similar equipment. Additional samples of the material within the sump will be collected if biasing factors (e.g., staining, odors, radioactivity) are identified during excavation. Four surface ( 0.0 to $0.5 \mathrm{ft}$ bgs) samples will be collected of the soil surrounding each side of the sump. The samples will be collected using a grab sampling technique. If biasing factors are encountered during excavation and sample collection, additional samples will be collected from locations selected by the Site Supervisor.

Steam Cleaning Pad and Outfall - The outfall will be surveyed to determine whether the drain located on the adjacent steam cleaning pad is the source. If the pipe is associated with the drain and is a discharge pipe, then one surface (0.0 to 0.5$)$ sample will be collected at the outfall opening. If it is determined that the pipe was a conduit pipe or some other feature that is not suspected to be a source of environmental concern, then no samples will be collected at this location and additional investigation will be completed to determine the discharge point for the drain. Samples will be collected at the discharge point for the drain. Additionally, four surface (0.0 to $0.5 \mathrm{ft}$ bgs) samples will be collected of the soil surrounding each side of the steam cleaning pad.

If biasing factors are encountered during excavation and sample collection, additional samples will be collected from locations selected by the Site Supervisor.

Proposed Decision I sample locations are shown in Figure A.9-6. 


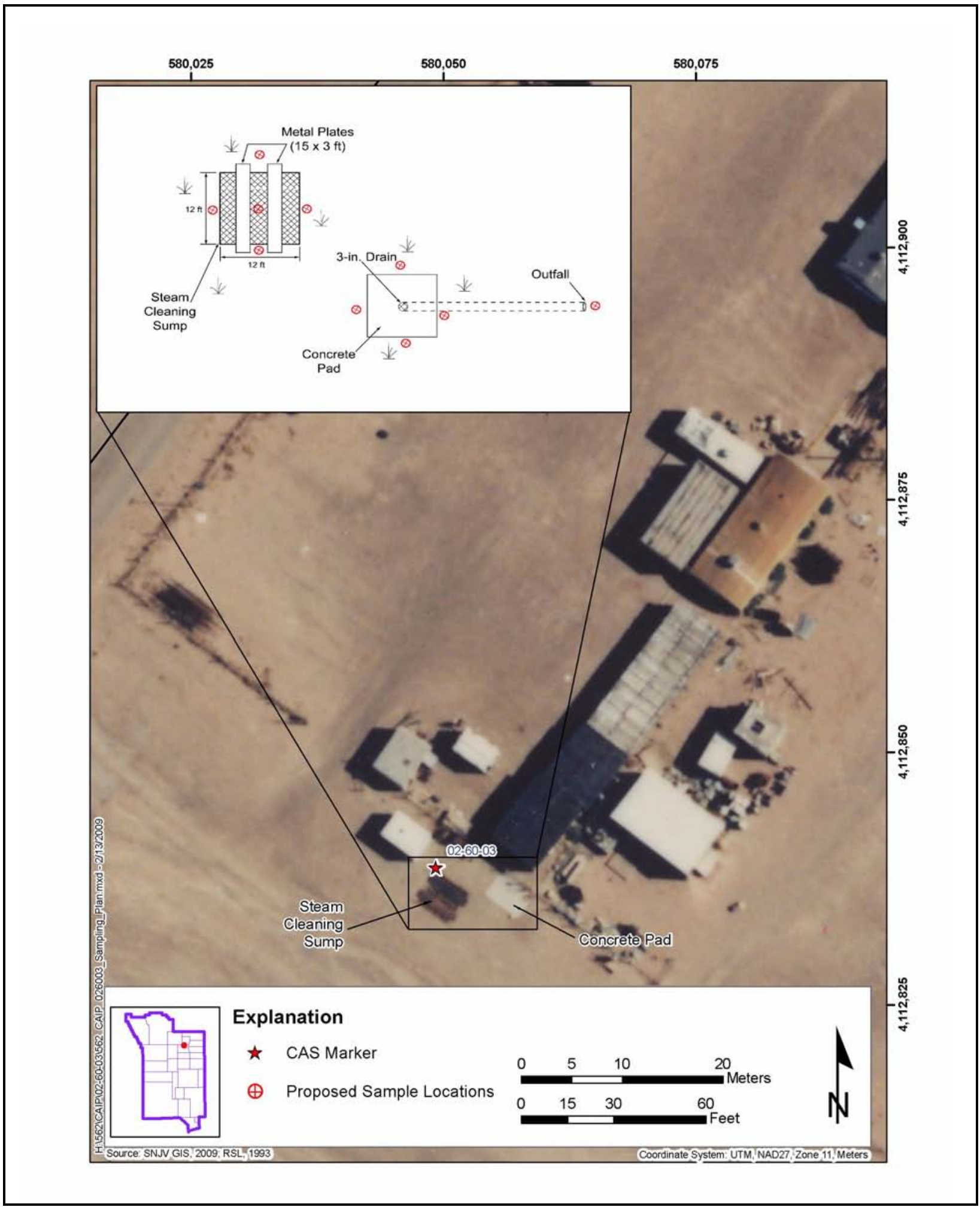

Figure A.9-6

Proposed Sample Locations at CAS 02-60-03, Steam Cleaning Drain 


\section{A.9.9 CAS 02-60-04, French Drain}

At CAS 02-60-04, the french drain and surrounding soil will be investigated. One sample will be collected from the lowest point from the interior of the french drain. Another sample will be collected at the native interface below the base of the drain. Because the drain is small in diameter; surrounded by thick, reinforced concrete; and has potentially been backfilled, the samples will be accessed using the most appropriate equipment to obtain the samples discussed (i.e., hand auger and/or backhoe). If biasing factors are encountered during the excavation, additional samples will be collected at locations selected by the Site Supervisor.

Proposed Decision I sample locations are shown in Figure A.9-7. 


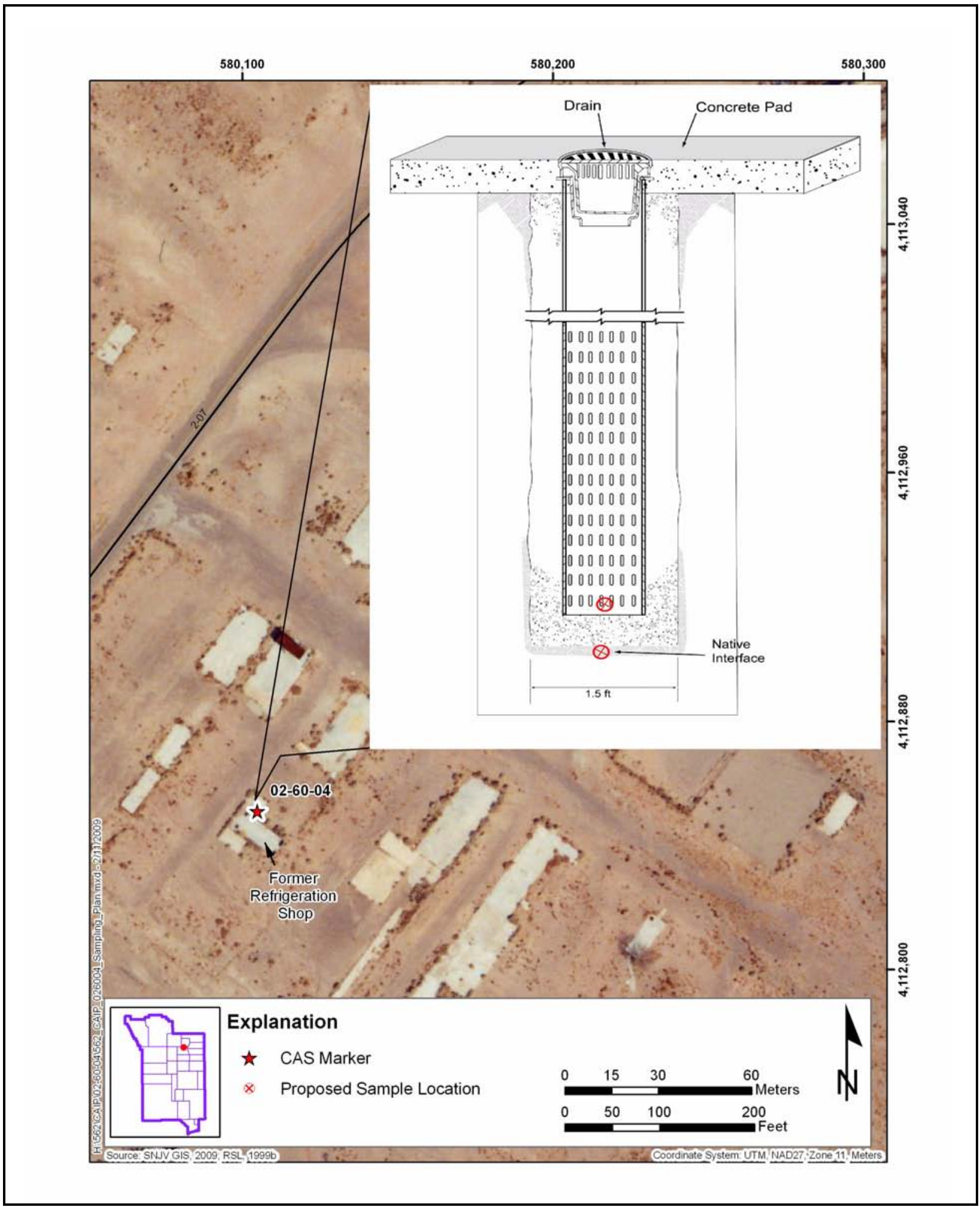

Figure A.9-7

Proposed Sample Locations at CAS 02-60-04, French Drain 


\section{A.9.10 CAS 02-60-05, French Drain}

At CAS 02-60-05, the french drain and surrounding soil will be investigated. One sample will be collected from the lowest point from the interior of the french drain. Another sample will be collected at the native interface below the base of the drain. The samples will be accessed using a backhoe or similar equipment, and collected using a grab sampling technique. If biasing factors are encountered during the excavation, additional samples will be collected at locations selected by the Site Supervisor.

Proposed Decision I sample locations are shown in Figure A.9-8. 


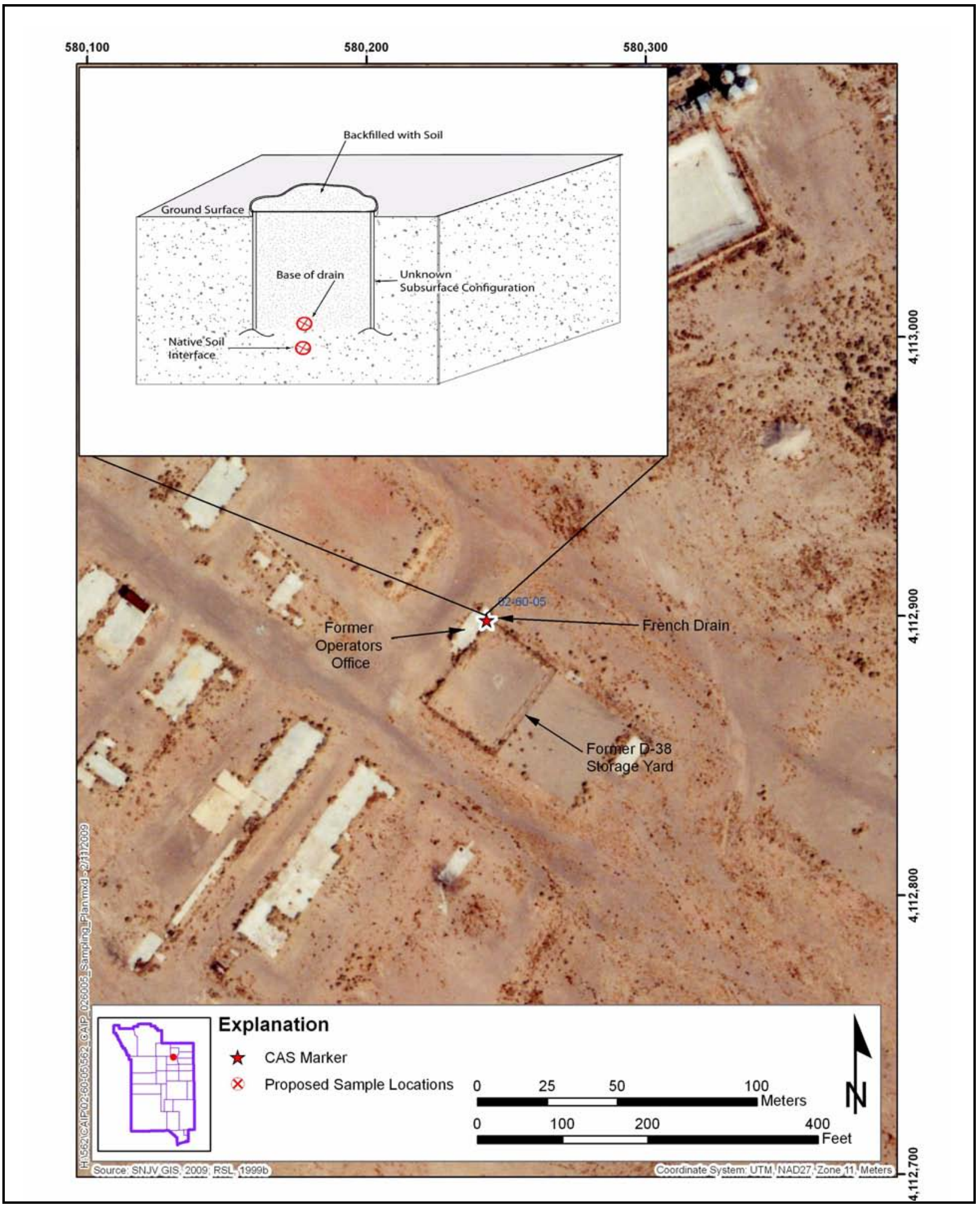

Figure A.9-8

Proposed Sample Locations at CAS 02-60-05, French Drain 


\section{A.9.11 CAS 02-60-06, French Drain}

At CAS 02-60-06, the french drain and surrounding soil will be investigated. The location of the french drain has not been identified due to heavy vegetation surrounding the associated building's foundation. Vegetation, and possibly some surface soil, will be removed to locate the french drain. If the feature identified is similar to the other french drains within CAU 562, a similar sampling strategy will be implemented. One sample will be collected from the lowest point from the interior of the french drain and another sample collected at the native interface below the base of the drain. If the feature identified has additional system components, such as piping, or is not similar to the other french drains in CAU 562, additional sampling or an altered sampling strategy will be performed as determined by the Site Supervisor. The Site Supervisor will use professional judgment to select locations most likely to be contaminated by a COC, if present. If the configuration of the system is different and is outside the scope of the CSM, work will be temporarily suspended and the situation reviewed. Recommendations will be made to the decision-makers on how to proceed.

The method used to access and collect samples will be determined during the field investigation. If biasing factors are encountered during the excavation to access sample locations, additional samples will be collected.

Because the configuration of the french drain is not known, a figure showing the proposed Decision I sample locations is not included.

\section{A.9.12 CAS 02-60-07, French Drain}

At CAS 02-60-07, the french drain and surrounding soil will be investigated. The location of the french drain has not been identified due to heavy vegetation surrounding the associated building's foundation. Vegetation, and possibly some surface soil, will be removed to locate the french drain. If the feature identified is similar to the other french drains within CAU 562, a similar sampling strategy will be implemented. One sample will be collected from the lowest point from the interior of the french drain and another sample collected at the native interface below the base of the drain. If the feature identified has additional system components, such as piping, or is not similar to the other french drains in CAU 562, additional sampling or an altered sampling strategy will be performed as determined by the Site Supervisor. The Site Supervisor will use professional judgment to select 
locations most likely to be contaminated by a COC, if present. If the configuration of the system is different and is outside the scope of the CSM, work will be temporarily suspended and the situation reviewed. Recommendations will be made to the decision-makers on how to proceed.

The method used to access and collect samples will be determined during the field investigation. If biasing factors are encountered during the excavation to access sample locations, additional samples will be collected.

Because the configuration of the french drain is not known, a figure showing the proposed Decision I sample locations is not included.

\section{A.9.13 CAS 23-60-01, Mud Trap Drain and Outfall}

At CAS 23-60-01, the following features will be investigated:

Mud Trap - A sample of the material located in the trench drain within the wash shed that leads to the mud trap will be collected. This sample will be collected from the location where the largest volume of sediments exist. The drain will be inspected for the presence of biasing factors (e.g., staining, radioactivity, odors). If biasing factors are present, additional representative sample(s) of the sediments will be collected. A sample will also be collected for each phase of material present within the mud trap. The samples will be collected using the most appropriate method for the material being collected (e.g., COLIWASA for liquid, extended scoop for sludge). Samples outside the mud trap will not be collected due to accessibility issues. However, if COCs are identified inside the mud trap, samples may be collected below the inlet and outlet piping by hand excavation to determine whether there has been a release.

Grease Rack - The area below the grease rack will be visually surveyed to locate biasing factors from which sample locations will be selected. If no biasing factors are present, one surface ( 0.0 to $0.5 \mathrm{ft}$ bgs) sample will be collected from two locations beneath the grease rack, as shown in Figure A.9-9. If biasing factors are determined to be present below the layer of gravel, then the locations may be changed and/or additional samples may be collected. The samples will be collected using a grab sampling technique. 
Outfall - The opening of the outfall is not visible and will need to be excavated for sampling. One sample will be collected at the opening of the outfall. A visual survey will be conducted of the area downstream of the outfall to look for biasing factors. If biasing factors are identified, surface ( 0.0 to $0.5 \mathrm{ft}$ bgs) samples will be collected. Samples will be collected using a grab sampling technique.

Proposed Decision I sample locations are shown in Figure A.9-9. 


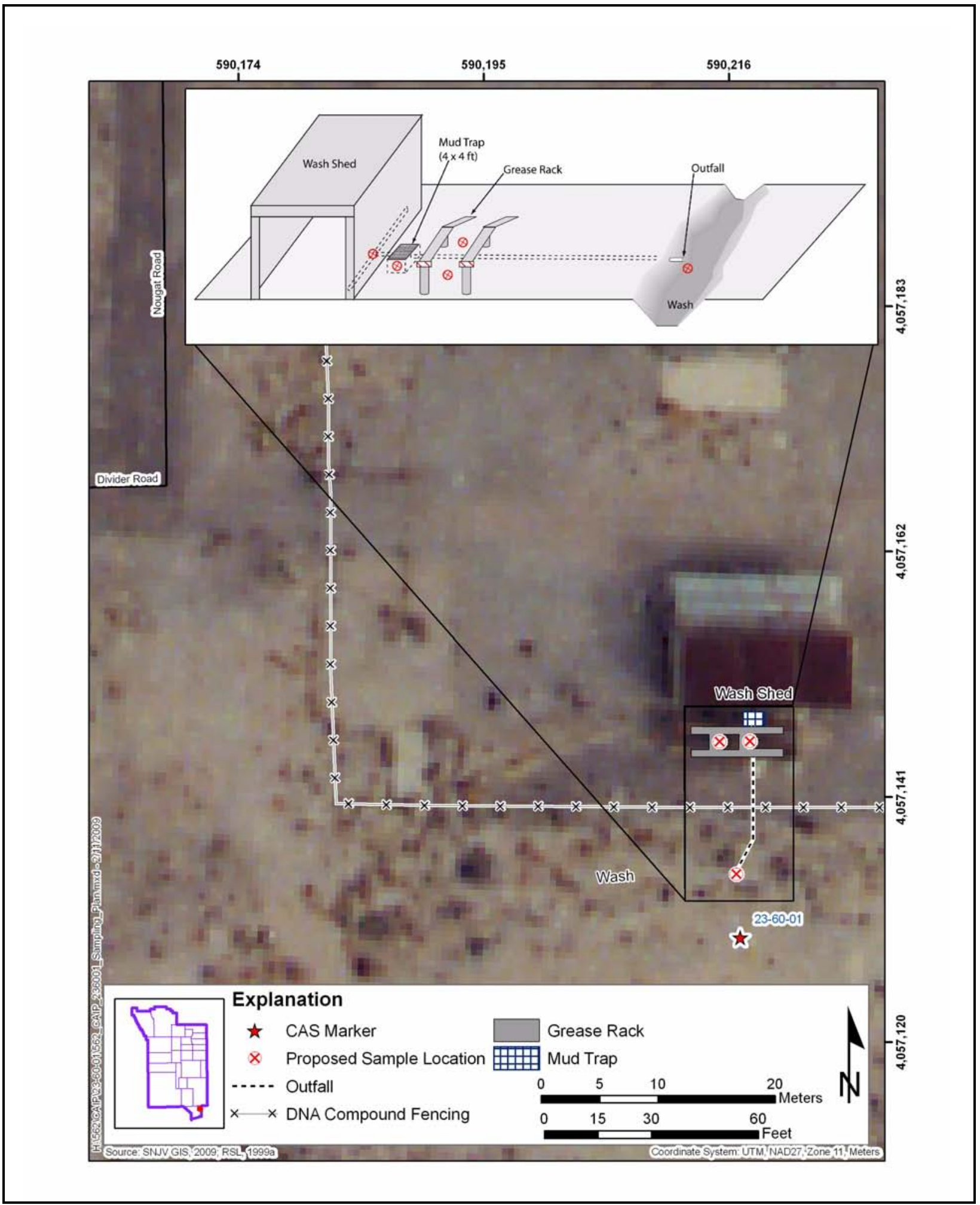

Figure A.9-9

Proposed Sample Locations at CAS 23-60-01, Mud Trap Drain and Outfall 


\section{A.9.14 CAS 23-99-06, Grease Trap}

At CAS 23-99-06, the grease trap will be investigated. Initial sampling will be to collect a sample of the contents of the grease pit. If this sample demonstrates that the contents are contaminated, then the sediments will be removed, and the base of the trap will be inspected for cracks. If the integrity of the pit is acceptable, then no further sampling will be conducted. However, if the pit is cracked, and it is determined that this is a significant vertical migration pathway, discussions will be held with NDEP to determine the path forward. A sample will be collected of the material present within the trap. The samples will be collected using the most appropriate method for accessing the material (e.g., extended scoop). Samples outside the grease trap will not be collected because of accessibility issues.

Proposed Decision I sample locations are shown in Figure A.9-10. 


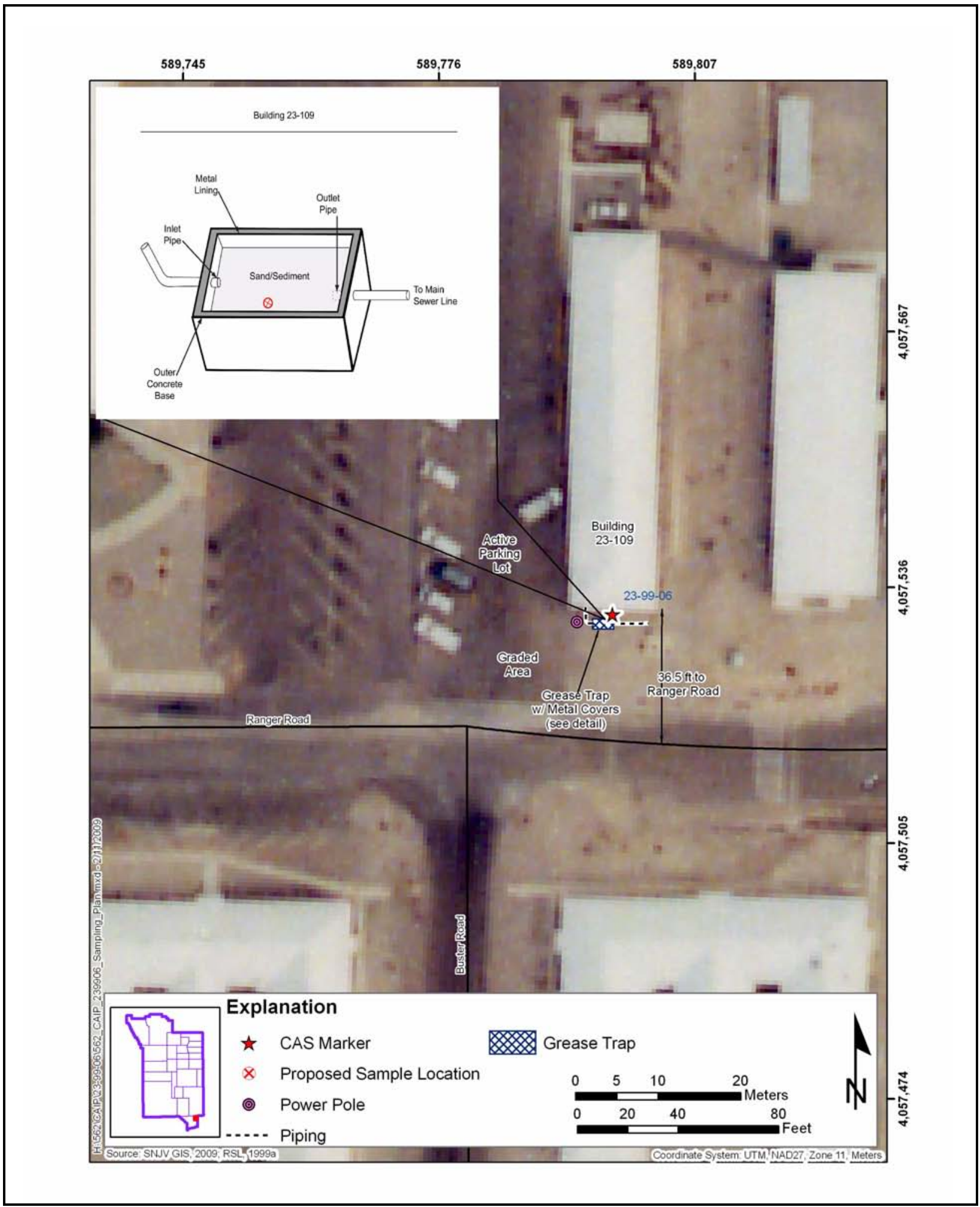

Figure A.9-10

Proposed Sample Locations at CAS 23-99-06, Grease Trap 


\section{A.9.15 CAS 25-60-04, Building 3123 Outfalls}

At CAS 25-60-04, the following features will be investigated:

Drain A - One sample will be collected at the elbow, which was the original outfall opening ( $25 \mathrm{ft}$ west of the building). Another sample will be collected at the current outfall opening (approximately $100 \mathrm{ft}$ south of the original outfall opening). A visual survey will be conducted to look for biasing factors. If biasing factors are identified, additional samples will be collected. Samples will be collected using a grab sampling technique.

Drain $\boldsymbol{B}$ - The opening of the outfall is not visible and will need to be hand excavated for sampling. One sample will be collected at the opening of the outfall. A visual survey will be conducted to look for biasing factors. If biasing factors are identified, additional samples will be collected. Samples will be collected using a grab sampling technique or another appropriate method if the pipe is not at a shallow depth.

The piping configuration for both outfalls, Drains A and B, will be determined through either excavation, camera survey, or a geophysical survey. Additional samples may be collected if biasing factors are found (e.g., at pipe ends, joints, breaches).

Proposed Decision I sample locations are shown in Figure A.9-11. 


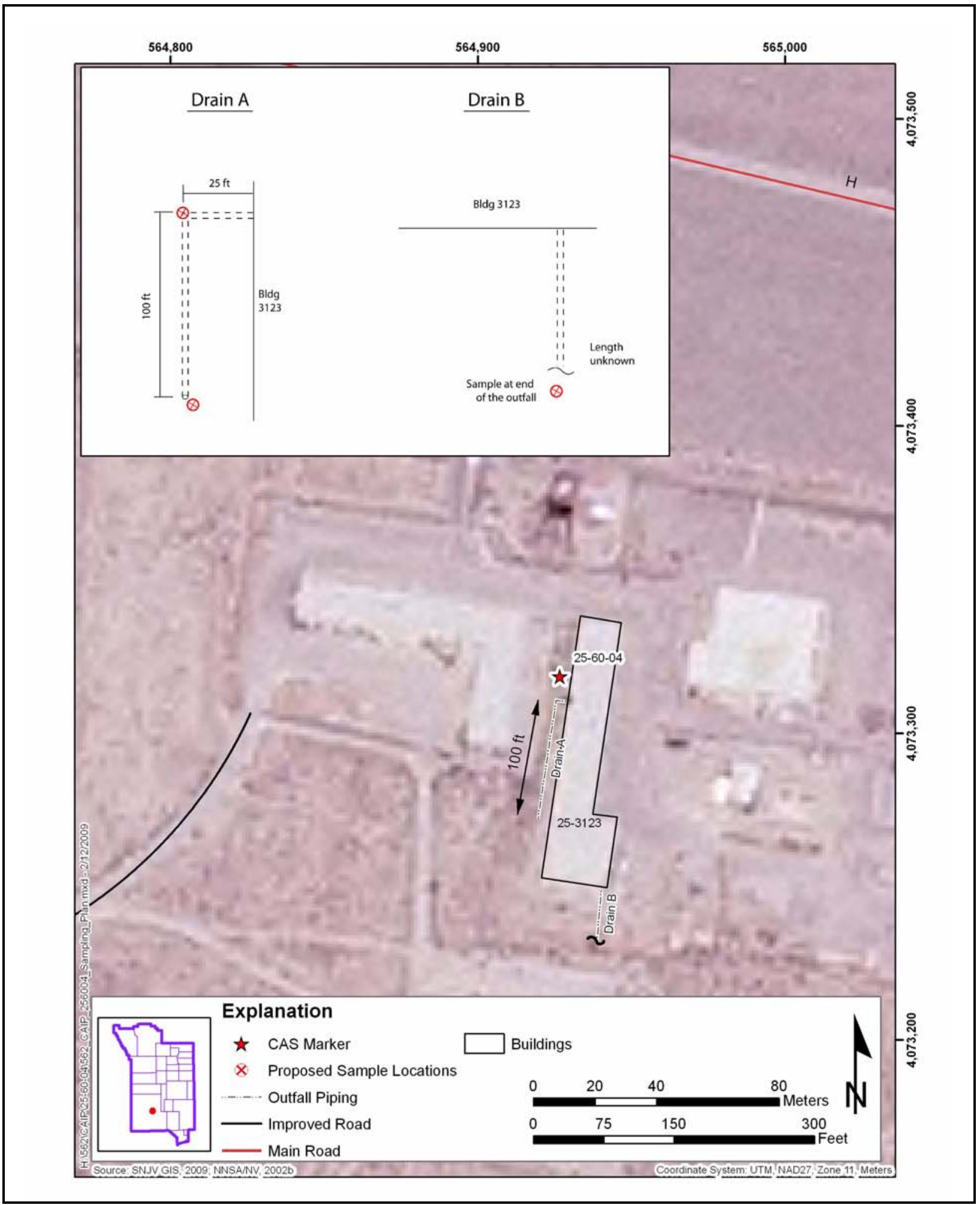

Figure A.9-11

Proposed Sample Locations at CAS 25-60-04, Building 3123 Outfalls 


\section{A.10.0 References}

ARL/SORD, see Air Resources Laboratory/Special Operations and Research Division.

ASTM, see American Society for Testing and Materials.

Air Resources Laboratory/Special Operations and Research Division. 2008. NTS Climatological Rain Gauge Data. As accessed at http://www.sord.nv.doe.gov/home_climate_rain.htm on 26 March 2009.

American Society for Testing and Materials. 1995. Standard Guide for Risk-Based Corrective Action Applied at Petroleum Release Sites, ASTM E 1739-95 (Reapproved 2002). Philadelphia, PA.

DOE, see U.S. Department of Energy.

DOE/NV, see U.S. Department of Energy, Nevada Operations Office.

EPA, see U.S. Environmental Protection Agency.

Moore, J., Science Applications International Corporation. 1999. Memorandum to M Todd (SAIC) entitled, “Background Concentrations for NTS and TTR Soil Samples,” 3 February.

Las Vegas, NV: IT Corporation.

Murphy, T., Bureau of Federal Facilities. 2004. Letter to R. Bangerter (NNSA/NSO) entitled, "Review of Industrial Sites Project Document Guidance for Calculating Industrial Sites Project Remediation Goals for Radionuclides in Soil Using the Residual Radiation (RESRAD) Computer Code,” 19 November. Las Vegas, NV.

NAC, see Nevada Administrative Code.

NBMG, see Nevada Bureau of Mines and Geology.

NCRP, see National Council on Radiation Protection and Measurements.

NNSA/NSO, see U.S. Department of Energy, National Nuclear Security Administration Nevada Site Office.

NNSA/NV, see U.S. Department of Energy, National Nuclear Security Administration Nevada Operations Office.

National Council on Radiation Protection and Measurements. 1999. Recommended Screening Limits for Contaminated Surface Soil and Review of Factors Relevant to Site-Specific Studies, NCRP Report No. 129. Bethesda, MD. 
Nevada Administrative Code. 2006a. NAC 445A.227, “Contamination of Soil: Order by Director for Corrective Action; Factors To Be Considered in Determining Whether Corrective Action Required.” Carson City, NV. As accessed at http://www.leg.state.nv.us/nac on 22 January 2009.

Nevada Administrative Code. 2006b. NAC 445A.22705, “Contamination of Soil: Evaluation of Site by Owner or Operator; Review of Evaluation by Division.” Carson City, NV. As accessed at http://www.leg.state.nv.us/nac on 22 January 2009.

Nevada Administrative Code. 2006c. NAC 445A.2272, “Contamination of Soil: Establishment of Action Levels.” Carson City, NV. As accessed at http://www.leg.state.nv.us/nac on 22 January 2009.

Nevada Bureau of Mines and Geology. 1998. Mineral and Energy Resource Assessment of the Nellis Air Force Range, Open-File Report 98-1. Reno, NV.

REECo, see Reynolds Electrical \& Engineering Co., Inc.

RSL, see Remote Sensing Laboratory.

Remote Sensing Laboratory. 1993. Aerial photograph “7472-04 \#2,” June 1. Las Vegas, NV: EG\&G Energy Measurements, Inc.

Remote Sensing Laboratory. 1999a. Aerial photograph “9997-8,” March 14. Las Vegas, NV.

Remote Sensing Laboratory. 1999b. Aerial photograph “9997-24,” March 14. Las Vegas, NV.

Reynolds Electrical \& Engineering Co., Inc. 1995. Area 2 Base Camp Closure Demolition and Environmental Total Estimated Cost. August. U.S. Department of Energy, Project Development and Management Division.

SNJV GIS, see Stoller-Navarro Joint Venture Geographic Information Systems.

Shott, G.J., V. Yucel, M.J. Sully, L.E. Barker, S.E. Rawlinson, and B.A. Moore. 1997. Performance Assessment/Composite Analysis for the Area 3 Radioactive Waste Management Site at the Nevada Test Site, Nye County, Nevada, Rev. 2.0. Las Vegas, NV.

Stoller-Navarro Joint Venture Geographic Information Systems. 2009. ESRI ArcGIS Software.

USGS, see U.S. Geological Survey.

U.S. Department of Energy. 1993. Radiation Protection of the Public and the Environment, DOE Order 5400.5, Change 2. Washington, DC: U.S. Government Printing Office. 
U.S. Department of Energy, National Nuclear Security Administration Nevada Operations Office. 2002a. Industrial Sites Quality Assurance Project Plan, Nevada Test Site, Nevada, Rev. 3, DOE/NV--372. Las Vegas, NV.

U.S. Department of Energy, National Nuclear Security Administration Nevada Operations Office. 2002b. Nevada Test Site Orthophoto Site Atlas, DOE/NV/11718--604. Aerial photos acquired Summer 1998. Prepared by Bechtel Nevada. Las Vegas, NV.

U.S. Department of Energy, National Nuclear Security Administration Nevada Site Office. 2006. Industrial Sites Project Establishment of Final Action Levels, Rev. 0, DOE/NV--1107. Las Vegas, NV.

U.S. Department of Energy, Nevada Operations Office. 1992. Remedial Investigation and Feasibility Study for the Plutonium Contaminated Soils at Nevada Test Site, Nellis Air Force Range and Tonopah Test Range. April. Las Vegas, NV.

U.S. Environmental Protection Agency. 2002. Guidance for Quality Assurance Project Plans, EPA QA/G5. Washington, DC.

U.S. Environmental Protection Agency. 2006. Guidance on Systematic Planning Using the Data Quality Objectives Process, EPA QA/G-4. Washington, DC.

U.S. Environmental Protection Agency. 2008. Region 9: Superfund, Preliminary Remediation Goals, Screening Levels for Chemical Contaminants. As accessed at http://www.epa.gov/region09/waste/sfund/prg/index.html on 4 December 2008. Prepared by EPA Office of Superfund and Oak Ridge National Laboratory.

U.S. Geological Survey. 2008. “Ground-Water Levels for Nevada.” As accessed at http://nwis.waterdata.usgs.gov/nv/nwis/gwlevels on 4 December 2008.

Weston, see Weston Solutions, Inc.

Weston Solutions, Inc. 2007. After Action Report: Technical Services for Preliminary Assessment Geophysical Investigations, Nevada Test Site Corrective Action Sites, Nye County, Nevada. September. Prepared for Stoller-Navarro Joint Venture. West Chester, PA. 
CAU 562 Closure Report

Section: Appendix A

Revision: 0

Date: August 2012

\section{THIS PAGE INTENTIONALLY LEFT BLANK}


Revision: 0

Date: August 2012

\section{APPENDIX B}

\section{SAMPLE ANALYTICAL RESULTS}


CAU 562 Closure Report

Section: Appendix B

Revision: 0

Date: August 2012

\section{THIS PAGE INTENTIONALLY LEFT BLANK}


ORGANIC ANALYSIS DATA SHEET $8270 \mathrm{C}$

Laboratory: Lionville Laboratory

Client: National Security Technologies, LLC

Matrix: Soil

Sampled:

12/15/11 12:30

Solids:

94.38

Batch:

L112372
Laboratory ID:

Prepared:

Preparation:
024402-VI $\underline{\text { SDG \#V3692 }}$

Miscellaneous

File $\mathrm{ID}$ :

D010316.D

Analyzed: $\quad \underline{0 \mathrm{I} / 03 / 1218: 54}$

Initial/Final: $\quad 30.31 \mathrm{~g} / 1 \mathrm{~mL}$ 1201003 Instrument:

HP5972D

Sequence: 2010018

Calibration:

CONC. (ug/kg dry)

1
52.4

\begin{tabular}{|l||}
\hline INTERNAL STANDARD \\
\hline 1,4-Dichlorobenzene-d4 \\
\hline Naphthalene-d8
\end{tabular}

Acenaphthene-di

Phenanthrene-d 10

Chrysene-d12

Perylene-d12

\begin{tabular}{|c|c}
\hline AREA & RT \\
\hline 84842 & 4.082 \\
\hline 281658 & 6.576 \\
\hline 130681 & 10.55 \\
\hline 176114 & 13.916 \\
\hline 164275 & 19.73 \\
\hline 193423 & 21.635 \\
\hline
\end{tabular}

* Value outside of QC limits 
ORGANIC ANALYSIS DATA SHEET

$8270 \mathrm{C}$
024402-V2

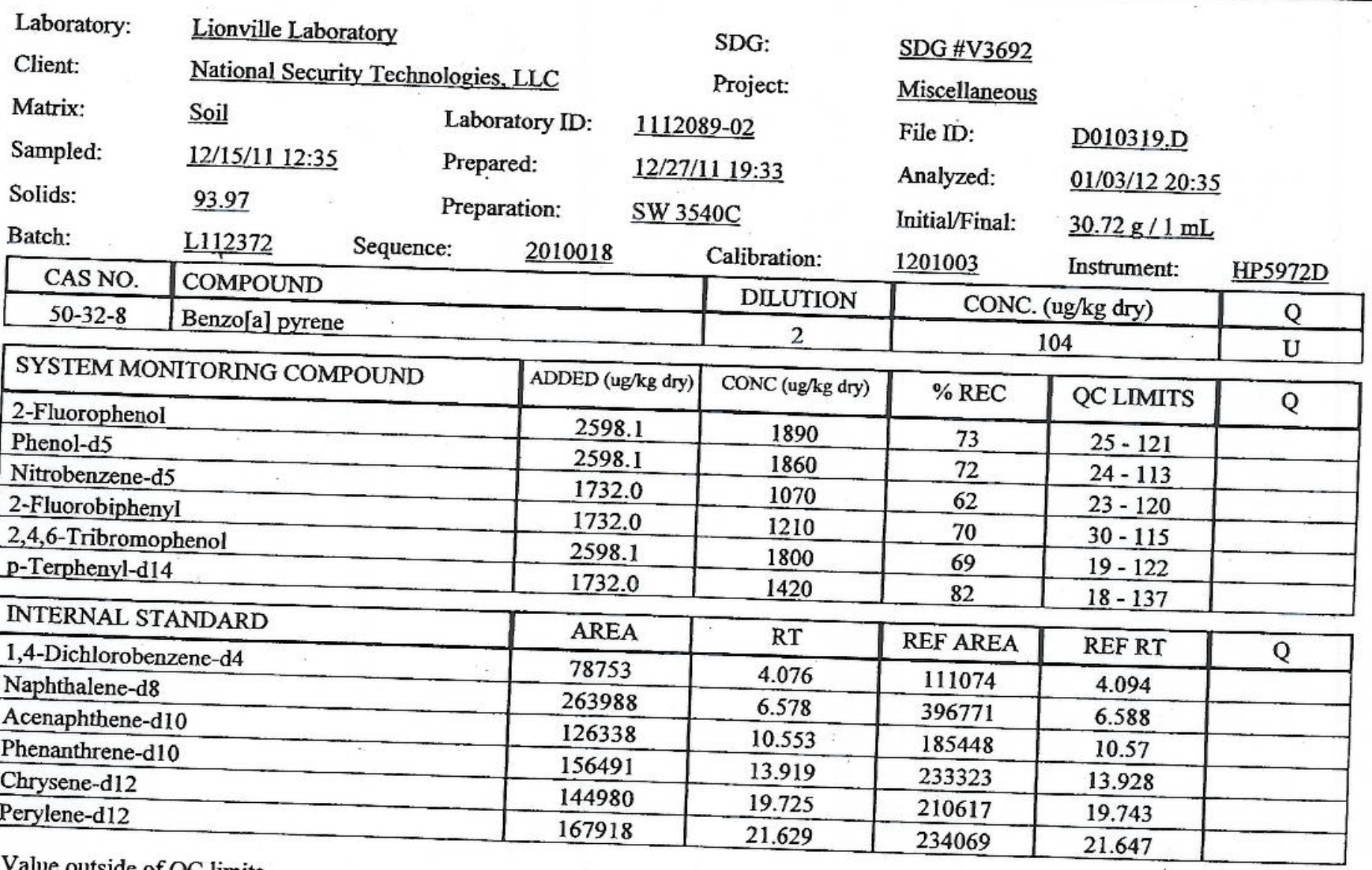

* Value outside of QC limits 


\section{ORGANIC ANALYSIS DATA SHEET 8270C SIM}

Laboratory: Lionville Laboratory

Client: National Security Technologies, LLC

Matrix: $\quad \underline{\text { Soil }}$

Sampled:

Laboratory ID:

12/15/11_13:10

Prepared:

SDG:

Project:

$\underline{\mathrm{SDG} \# \mathrm{~V} 3692}$

Miscellaneous

Solids:

Preparation: $\quad$ SW $3540 \mathrm{C}$

1112089-03

12/27/11 19:33

File ID:

C011114.D

Batch:

L201100

\begin{tabular}{|c|l|}
\hline CAS NO. & COMPOUND \\
\hline $50-32-8$ & Benzo[a] pyrene \\
\hline
\end{tabular}

\begin{tabular}{|l|c|}
\hline SYSTEM MONITORING COMPOUND & ADDED (ug/kg dry) \\
\hline Nitrobenzene-d5 & 1805.5 \\
\hline 2-Fluorobiphenyl & 1805.5 \\
\hline p-Terphenyl-d14 & 1805.5 \\
\hline INTERNAL STANDARD & AREA \\
\hline Naphthalene-d8 & 985939 \\
\hline Acenaphthene-d10 & 589190 \\
\hline Phenanthrene-d10 & 805011 \\
\hline Chrysene-d12 & 1227294 \\
\hline Perylene-d12 & 751675 \\
\hline
\end{tabular}

* Value outside of QC limits

Analyzed: $\quad \underline{01 / 11 / 1223: 35}$

Initial/Final: $\quad \underline{30 \mathrm{~g} / 4 \mathrm{~mL}}$ Calibration:

Instrument:

HP5972C 131 \begin{tabular}{l|l} 
DILUTION & CONC. (ug/kg dry) \\
\hline
\end{tabular} Q 1

-

\begin{tabular}{|c|c|c|c|}
\hline CONC (ug/kg dry) & \% REC & QC LIMITS & Q \\
\hline 1630 & 90 & $23-120$ & \\
\hline 1510 & 83 & $30-115$ & \\
\hline 1240 & 69 & $18-137$ & \\
\hline
\end{tabular}

\begin{tabular}{|c|c|c|c|}
\hline RT & REF AREA & REF RT & Q \\
\hline 11.647 & 1583859 & 11.629 & \\
\hline 16.034 & 947032 & 16.034 & \\
\hline 19.561 & 1219423 & 19.533 & \\
\hline 24.182 & 1474936 & 24.181 & \\
\hline 28.612 & 856585 & 28.592 & \\
\hline
\end{tabular}




\section{ORGANIC ANALYSIS DATA SHEET 8270C SIM}

026003-V2

Laboratory: Lionville Laboratory

Client: : National Security Technologies, LLC

Matrix: $\quad \underline{\text { Soil }}$

Sampled: $\quad \underline{12 / 15 / 1113: 15}$

Laboratory ID:

Prepared:

Solids:

91.36

Preparation:

Batch:

L201100 Sequence:

1112089-04

12/27/1119:33

SW 3540C

SDG:

Project:

\begin{tabular}{|c|l|c|c|c|c|}
\hline CAS NO. & COMPOUND & \multicolumn{2}{|c|}{ Calibration: } & \multicolumn{1201015}{c}{ Instrument: } & HP5972C \\
\hline $50-32-8$ & Benzo[a] pyrene & DILUTION & CONC. (ug/kg dry) & Q \\
\hline
\end{tabular}

\begin{tabular}{|l|c|c|c|c|c|}
\hline SYSTEM MONITORING COMPOUND & ADDED (ug/kg dry) & CONC (ug/kg dry) & $\%$ REC & QC LIMITS & Q \\
\hline Nitrobenzene-d5 & 1797.3 & 1420 & 79 & $23-120$ & \\
\hline 2-Fluorobiphenyl & 1797.3 & 1350 & 75 & $30-115$ & \\
\hline p-Terphenyl-d14 & 1797.3 & 1310 & 73 & $18-137$ & \\
\hline
\end{tabular}

\begin{tabular}{l} 
Naphthalene-d8 \\
\hline
\end{tabular}

Acenaphthene-d10

Phenanthrene-d 10

Chrysene-d12

Perylene-d12

2

\begin{tabular}{|c|c|}
\hline AREA \\
\hline 1131559 \\
\hline 647852 \\
\hline 988400 \\
\hline 1485729 \\
\hline 984883 \\
\hline
\end{tabular}

* Value outside of QC limits

\begin{tabular}{|c|c|c|c|}
\hline RT & REF AREA & REF RT & Q \\
\hline 11.646 & 1583859 & 11.629 & \\
\hline 16.035 & 947032 & 16.034 & \\
\hline 19.561 & 1219423 & 19.533 & \\
\hline 24.182 & 1474936 & 24.181 & \\
\hline 28.63 & 856585 & 28.592 & \\
\hline
\end{tabular}

File ID: $\quad$ C011115.D

Analyzed: $\quad \underline{01 / 12 / 1200: 21}$

Initial/Final: $\quad \underline{30.45 \mathrm{~g} / 2 \mathrm{~mL}}$ Instrument:

SDG\#V3692

Miscellaneous 


\section{ORGANIC ANALYSIS DATA SHEET}

8082

Laboratory: Lionville Laboratory

Client:

Matrix:

Sampled:

Solids:

National Security Technologies, LLC

$$
\text { Soil }
$$

Batch:
Laboratory ID

Prepared:

Preparation:

\section{SDG: $\quad$ SDG \#V3692 \\ Project: Miscellaneous}

1112089-05

12/23/11 15:32

SW 3540C

File ID:

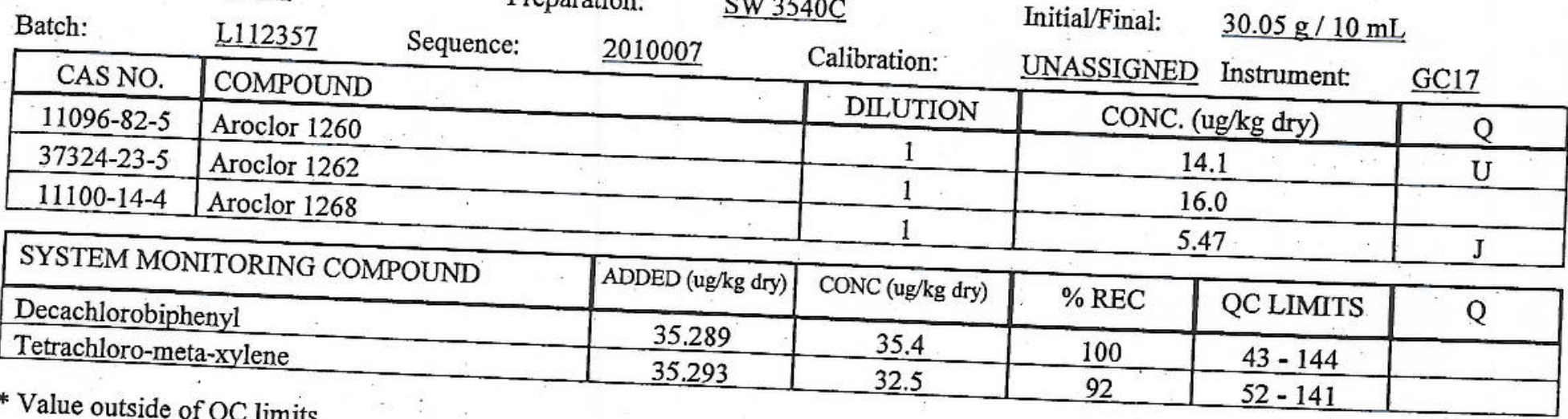

* Value outside of QC limits

026003-V3

LIMS_EXPORT3415

Analyzed: $\quad$ 01/03/12 20:34 Initial/Final: $\quad 30.05 \mathrm{~g} / 10 \mathrm{~mL}$ UNASSIGNED Instrument: $\mathrm{GC17}$ 


\section{ORGANIC ANALYSIS DATA SHEET \\ 8082}

026003-V4

Laboratory: Lionville Laboratory

Client:

Matrix:

. National Security Technologies, LLC

SDG:

SDG \#V3692

Project: Miscellaneous

Sampled:

Laboratory ID:

1112089-06

Prepared:

12/23/11 15:32

Solids: $\quad \underline{92.97}$

Preparation: $\quad$ SW $3540 \mathrm{C}$

Batch:

L112357

2010007

Calibration:

File ID:

LIMS EXPORT3537

Analyzed: $\quad \underline{01 / 03 / 1222: 35}$

SYSTEM MONITORING COMPOUND

ADDED (ug/kg dry)

CONC (ug/kg dry)

Decachlorobiphenyl

35.535

35.538

44.3

42.2

* Value outside of QC limits

\begin{tabular}{|c|c|c|}
\hline$\%$ REC & QC LIMITS & Q \\
\hline 125 & $43-144$ & \\
\hline 119 & $52-141$ & \\
\hline
\end{tabular}




\section{ORGANIC ANALYSIS DATA SHEET $8270 \mathrm{C}$}

Laboratory: Lionville Laboratory

Client:

Matrix:

Sampled:

Solids:

National Security Technologies, LLC

Soil

Batch:

12/15/11 13:25

91.76

$\underline{\mathrm{L} 112372}$

COMPOUND

Sequence:

Laboratory ID:

Prepared:

Preparation:
SDG:

Project:

1112089-07

12/27/1119:33

SW $3540 \mathrm{C}$

\begin{tabular}{|c|c|c|c|c|c|c|}
\hline & Sequence: & 2010018 & Calibration: & 1201003 & Instrument: & HP5972D \\
\hline $129-00-0$ & & & DILUTION & \multicolumn{2}{|c|}{ CONC. (ug/kg dry) } & $\mathrm{Q}$ \\
\hline $56-55-3$ & & & 1 & \multicolumn{2}{|c|}{53.9} & $\mathrm{U}$ \\
\hline & $z$ [a]anthracene & & 1 & \multicolumn{2}{|c|}{53.9} & $\mathrm{U}$ \\
\hline $207-08-9$ & Benzo[b] fluoranthene & & 1 & \multicolumn{2}{|c|}{53.9} & $\mathrm{U}$ \\
\hline $50-32-8$ & $\begin{array}{l}\text { Benzo[k] fluoranthene } \\
\text { Benzo[a] pyrene }\end{array}$ & & 1 & \multicolumn{2}{|c|}{53.9} & $\mathrm{U}$ \\
\hline $193-39-5$ & \begin{tabular}{|l} 
Benzo[a] pyrene \\
Indeno[1.2,3-cdlnyrene
\end{tabular} & & 1 & \multicolumn{2}{|c|}{53.9} & $\bar{U}$ \\
\hline $53-70-3$ & \begin{tabular}{|l} 
Indeno[1,2,3-cd]pyrene \\
Dibenz[a,h]anthracene
\end{tabular} & & 1 & \multicolumn{2}{|c|}{53.9} & $\mathrm{U}$ \\
\hline \multirow{2}{*}{\multicolumn{2}{|c|}{ SYSTEM MONITORING COMPOUND }} & & 1 & \multicolumn{2}{|c|}{53.9} & $\mathrm{U}$ \\
\hline & & ADDED (ug/kg dry) & CONC (ug/kg dry) & $\%$ REC & QC LIMITS & Q \\
\hline \multicolumn{2}{|l|}{ 2-Fluorophenol } & 2695.7 & 1920 & 71 & $25-121$ & \\
\hline \multicolumn{2}{|c|}{ Phenol-d5 } & 2695.7 & 1880 & 70 & $24-113$ & \\
\hline \multicolumn{2}{|c|}{ Nitrobenzene-d5 } & 1797.2 & 1220 & 68 & $23-120$ & \\
\hline \multicolumn{2}{|c|}{ 2-Fluorobiphenyl } & 1797.2 & 1300 & 73 & $30-115$ & \\
\hline \multicolumn{2}{|c|}{ 2,4,6-Tribromophenol } & 2695.7 & 1450 & 54 & $19-122$ & \\
\hline \multicolumn{2}{|c|}{$p$-Terphenyl-dl 4} & 1797.2 & 1590 & 89 & $18-137$ & \\
\hline \multicolumn{2}{|c|}{ INTERNAL STANDARD } & AREA & $\overline{R T}$ & REF AREA & REF RT & $\bar{Q}$ \\
\hline \multicolumn{2}{|c|}{ 1,4-Dichlorobenzene-d4 } & 98993 & 4.09 & 111074 & 4.094 & \\
\hline \multicolumn{2}{|c|}{$\begin{array}{l}\text { Naphthalene-d8 } \\
\text { Acenaphthene-d10 }\end{array}$} & 339382 & 6.584 & 396771 & 6.588 & \\
\hline \multicolumn{2}{|c|}{ Acenaphthene-d10 } & 173138 & 10.558 & 185448 & 10.57 & \\
\hline \multicolumn{2}{|c|}{$\begin{array}{l}\text { Phenanthrene-dlo } \\
\text { Chrysene-d12 }\end{array}$} & 239807 & 13.924 & 233323 & 13.928 & \\
\hline \multirow{2}{*}{\multicolumn{2}{|c|}{$\begin{array}{l}\text { Chrysene-d } 12 \\
\text { Perylene-d12 }\end{array}$}} & 213924 & 19.739 & 210617 & 19.743 & \\
\hline & Perylene-d12 & 232853 & 21.634 & 234069 & 21.647 & \\
\hline
\end{tabular}

\footnotetext{
* Value outside of QC limits
}

026005-V1

SDG \#V3692

Miscellaneous

File ID:

Analyzed: $\quad \underline{01 / 03 / 1215: 32}$

Initial/Final: $\quad \underline{30.32 \mathrm{~g} / 1 \mathrm{~mL}}$

30.32 $\mathrm{g} / 1 \mathrm{~mL}$

D010310.D

\section{2}


ORGANIC ANALYSIS DATA SHEET

8270C
026005-V2

Laboratory: Lionville Laboratory

Client:

Matrix:

Sampled:

National Security Technologies, LLC

$\underline{\text { Soil }}$

Solids:

$12 / 15 / 1113: 30$

Laboratory ID:

Prepared:

$\underline{91.78}$

Batch:

$$
\underline{\mathrm{L} 112372}
$$

Preparation:
SDG:

Project:

1112089-08

$12 / 27 / 1119: 33$

SW $3540 \mathrm{C}$

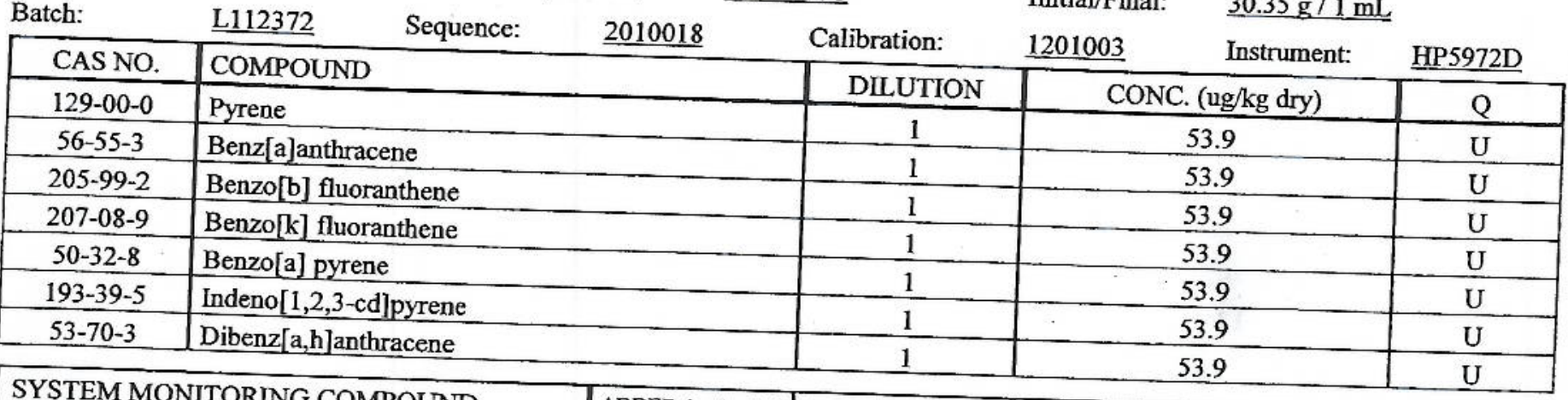

\begin{tabular}{|l|c|c||c|c|c|}
\hline SYSTEM MONITORING COMPOUND & ADDED (ug/kg dry) & CONC (ug/kg dry) & $\%$ REC & QC LIMITS & Q \\
\hline 2-Fluorophenol & 2692.6 & 1910 & 71 & $25-121$ & \\
\hline Phenol-d5 & 2692.6 & 1840 & 68 & $24-113$ & \\
\hline Nitrobenzene-d5 & 1795.1 & 1260 & 70 & $23-120$ & \\
\hline 2-Fluorobiphenyl & 1795.1 & 1460 & 81 & $30-115$ & \\
\hline 2,4,6-Tribromophenol & 2692.6 & 1780 & 66 & $19-122$ & \\
\hline p-Terphenyl-d14 & 1795.1 & 1530 & 85 & $18-137$ & \\
\hline
\end{tabular}

\begin{tabular}{|l|c|c|c|c|c|}
\hline INTERNAL STANDARD & AREA & RT & REF AREA & REF RT & Q \\
\hline 1,4-Dichlorobenzene-d4 & 100303 & 4.081 & 111074 & 4.094 & \\
\hline Naphthalene-d8 & 338610 & 6.583 & 396771 & 6.588 & 137 \\
\hline Acenaphthene-d10 & 161747 & 10.558 & 185448 & 10.57 & \\
\hline Phenanthrene-d10 & 220961 & 13.924 & 233323 & 13.928 & \\
\hline Chrysene-d12 & 208706 & 19.73 & 210617 & 19.743 & \\
\hline Perylene-d12 & 240728 & 21.634 & 234069 & 21.647 & \\
\hline
\end{tabular}

* Value outside of QC limits 
ORGANIC ANALYSIS DATA SHEET

$8270 \mathrm{C}$

Laboratory: Lionville Laboratory

Client: National Security Technologies, LLC

Matrix: Soil

Sampled:

12/15/1113:35

Solids:

90.58

Batch:

\begin{tabular}{|c|}
\hline CAS NO. \\
\hline $129-00-0$ \\
\hline $56-55-3$ \\
\hline $205-99-2$ \\
\hline $207-08-9$ \\
\hline $50-32-8$ \\
\hline $193-39-5$ \\
\hline $53-70-3$ \\
\hline
\end{tabular}

$\underline{\mathrm{L} 112372}$

Laboratory ID:

Prepared:

Preparation:


026005-V3

\begin{tabular}{|l|c|c|c|}
\hline COMPOUND & Calibration: & \multicolumn{1}{|c|}{ Instrument: } & \multicolumn{1}{l}{ HP5972D } \\
\hline Pyrene & DILUTION & CONC. (ug/kg dry) & $\mathrm{Q}$ \\
\hline Benz[a]anthracene & 1 & 54.3 & $\mathrm{U}$ \\
\hline Benzo[b] fluoranthene & 1 & 54.3 & $\mathrm{U}$ \\
\hline Benzo[k] fluoranthene & 1 & 54.3 & $\mathrm{U}$ \\
\hline Benzo[a] pyrene & 1 & 54.3 & $\mathrm{U}$ \\
\hline Indeno[1,2,3-cd]pyrene & 1 & 54.3 & $\mathrm{U}$ \\
\hline Dibenz[a,h]anthracene & 1 & 54.3 & $\mathrm{U}$ \\
\hline
\end{tabular}

\begin{tabular}{|l|c|c|c|c|c|}
\hline SYSTEM MONITORING COMPOUND & ADDED (ug/kg dry) & CONC (ug/kg dry) & $\%$ REC & QC LIMTS & Q \\
\hline 2-Fluorophenol & 2712.9 & 1470 & 54 & $25-121$ & \\
\hline Phenol-d5 & 2712.9 & 1860 & 68 & $24-113$ & \\
\hline Nitrobenzene-d5 & 1808.6 & 691 & 38 & $23-120$ & \\
\hline 2-Fluorobiphenyl & 1808.6 & 1350 & 75 & $30-115$ & \\
\hline 2,4,6-Tribromophenol & 2712.9 & 1470 & 54 & $19-122$ & \\
\hline p-Terphenyl-d14 & 1808.6 & 1750 & 97 & $18-137$ & \\
\hline
\end{tabular}

\begin{tabular}{|l|c|c|c|c|c|}
\hline INTERNAL STANDARD & AREA & RT & REF AREA & REF RT & Q \\
\hline 1,4-Dichlorobenzene-d4 & 82693 & 4.083 & 111074 & 4.094 & \\
\hline Naphthalene-d8 & 283143 & 6.585 & 396771 & 6.588 & \\
\hline Acenaphthene-d10 & 134428 & 10.559 & 185448 & 10.57 & \\
\hline Phenanthrene-d10 & 183974 & 13.925 & 233323 & 13.928 & \\
\hline Chrysene-d12 & 141571 & 19.732 & 210617 & 19.743 & \\
\hline Perylene-d12 & 155458 & 21.635 & 234069 & 21.647 & \\
\hline
\end{tabular}

* Value outside of QC limits

SDG: $\quad \underline{\text { SDG\#V3692 }}$

Project: Miscellaneous

1112089-09

12/27/11 19:33

SW 3540C
File ID:

Analyzed: $\quad \underline{01 / 03 / 1217: 47}$

Initial/Final: $\quad 30.52 \mathrm{~g} / 1 \mathrm{~mL}$ 
ORGANIC ANALYSIS DATA SHEET

$8270 \mathrm{C}$

Laboratory: Lionville Laboratory

Client: $\quad$ National Security Technologies, LLC

Matrix: $\quad \underline{\text { Soil }}$

Sampled:

$\underline{12 / 15 / 1113: 40}$

Solids: $\underline{94.56}$

Batch:

CAS NO.

L112372
Laboratory ID:

Prepared:

Preparation:
SDG:

Project:

1112089-10

12/27/11 19:33

SW $3540 \mathrm{C}$
026005-V4

\begin{tabular}{|c|l|c|c|c|}
\hline CAS NO. & COMPOUND & DILUTION & CONC. (ug/kg dry) & Q \\
\hline $129-00-0$ & Pyrene & 2 & 691 \\
\hline $56-55-3$ & Benz[a]anthracene & 2 & 413 & JD \\
\hline $205-99-2$ & Benzo[b] fluoranthene & 2 & Unstrument: & U \\
\hline $207-08-9$ & Benzo[k] fluoranthene & 2 & 413 \\
\hline $50-32-8$ & Benzo[a] pyrene & 2 & U \\
\hline $193-39-5$ & Indeno[1,2,3-cd]pyrene & 2 & 593 \\
\hline $53-70-3$ & Dibenz[a,h]anthracene & 2 & 413 & JD \\
\hline
\end{tabular}

\begin{tabular}{|c|c|c|c|c|c|}
\hline & & & & & U \\
\hline SYSIEM MONITORING COMPOUND & ADDED (ug/kg dry) & CONC (ug/kg dry) & $\%$ REC & QC LIMITS & $\mathrm{Q}$ \\
\hline 2-Fluorophenol & 2583.4 & 2400 & 93 & $25-121$ & \\
\hline Phenol-d5 & 2583.4 & 2370 & 92 & $24-113$ & \\
\hline Nitrobenzene-d5 & 1722.3 & 1390 & 81 & $23-120$ & \\
\hline 2-Fluorobiphenyl & 1722.3 & 1520 & 88 & $30-115$ & \\
\hline 2,4,6-Tribromophenol & 2583.4 & 0.00 & & $19-122$ & * \\
\hline p-Terphenyl-d 14 & 1722.3 & 1670 & 97 & $18-137$ & \\
\hline INTERNAL STANDARD & AREA & $\mathrm{RT}$ & REF AREA & REF RT & Q \\
\hline 1,4-Dichlorobenzene-d4 & 80648 & 4.085 & 111074 & 4.094 & \\
\hline Naphthalene-d8 & 274607 & 6.579 & 396771 & 6.588 & \\
\hline Acenaphthene-d10 & 135628 & 10.553 & 185448 & 10.57 & \\
\hline Phenanthrene-d I0 & 174077 & 13.919 & 233323 & 13.928 & \\
\hline Chrysene-d12 & $\mathrm{I} 49307$ & 19.725 & 210617 & 19.743 & \\
\hline Perylene-d12 & 164209 & 21.629 & 234069 & 21.647 & \\
\hline
\end{tabular}

* Value outside of QC limits 
ORGANIC ANALYSIS DATA SHEET

$8270 \mathrm{C}$

Laboratory: Lionville Laboratory

Client:

Matrix: Soil

Sampled:

Solids:

12/15/11 13:40

95.40

Batch:

L112372
SDG:

Project:

1112089-11

12/27/11 19:33

Prepared:

Preparation:

SW $3540 \mathrm{C}$
Sequence: $\quad 2010018$

Calibration:

CAS NO.

COMPOUND

129-00-0

56-55-3

205-99-2

207-08-9

50-32-8

193-39-5

53-70-3

Pyrene

Benz[a]anthracene

Benzo[b] fluoranthene

Benzo[k] fluoranthene

Benzo[a] pyrene

Indeno[1,2,3-cd]pyrene

Dibenz $[\mathrm{a}, \mathrm{h}]$ anthracene

$\underline{\text { SDG \#V3692 }}$

Miscellaneous

File ID:

D010315.D

Analyzed: $\quad \underline{01 / 03 / 12 ~ 18: 21}$

Initial/Final: $\quad 30.59 \mathrm{~g} / 1 \mathrm{~mL}$

\begin{tabular}{|l|l|}
\hline SYSTEM MONITORING COMPOUND & ADD \\
\hline 2-Fluorophenol & \\
\hline Phenol-d5 & \\
\hline Nitrobenzene-d5 & \\
\hline 2-Fluorobiphenyl & \\
\hline 2,4,6-Tribromophenol & \\
\hline p-Terphenyl-d14 & \\
\hline
\end{tabular}

\begin{tabular}{|l|c|}
\hline INTERNAL STANDARD & AREA \\
\hline 1,4-Dichlorobenzene-d4 & 87542 \\
\hline Naphthalene-d8 & 283755 \\
\hline Acenaphthene-d10 & 144123 \\
\hline Phenanthrene-d10 & 188445 \\
\hline Chrysene-d12 & 153197 \\
\hline Perylene-d12 & 165507 \\
\hline
\end{tabular}

* Value outside of QC limits

\begin{tabular}{|c|c|c|}
\hline DILUTION & CONC. (ug/kg dry) & Q \\
\hline 1 & 51.4 & $\mathrm{H}$ \\
\hline 1 & 51.4 & $\mathrm{U}$ \\
\hline 1 & 51.4 & $\mathrm{U}$ \\
\hline 1 & 51.4 & $\mathrm{U}$ \\
\hline 1 & 51.4 & $\mathrm{U}$ \\
\hline 1 & 51.4 & $\mathrm{U}$ \\
\hline 1 & 51.4 & $\mathrm{U}$ \\
\hline
\end{tabular}

\begin{tabular}{|c|c|c|c|c|}
\hline 2570.0 & 1600 & 62 & $25-121$ & \\
\hline 2570.0 & 1600 & 62 & $24-113$ & \\
\hline 1713.4 & 843 & 49 & $23-120$ & \\
\hline 1713.4 & 1250 & 73 & $30-115$ & \\
\hline 2570.0 & 1070 & 42 & $19-122$ & \\
\hline 1713.4 & 1490 & 87 & $18-137$ & \\
\hline
\end{tabular}

\begin{tabular}{|c|c|c|c|}
\hline RT & REF AREA & REF RT & Q \\
\hline 4.082 & 111074 & 4.094 & \\
\hline 6.576 & 396771 & 6.588 & \\
\hline 10.55 & 185448 & 10.57 & \\
\hline 13.916 & 233323 & 13.928 & \\
\hline 19.732 & 210617 & 19.743 & \\
\hline 21.635 & 234069 & 21.647 & \\
\hline
\end{tabular}


264 Welsh Pool Road

Exton, PA 19341

Phone: 610-280-3000

Fax: 610-280-3041

Project: Miscellaneous

National Security Technologies, LLC

M/S NTS025, PO Box 98521

Las Vegas NV, 89193-8521
Project Number: V3701

Project Manager: Accounts Payable
Reported:

01/31/2012 13:41

\section{2-60-05-V6}

1201051-01 (Soil)

\begin{tabular}{|lllllll}
\hline & & Reporting & & & \\
Analyte & Result and Qualifier & Limit & Units & Dilution & Batch & Prepared \\
\hline
\end{tabular}

\section{Lionville Laboratory}

Semivolatile Organic Compounds by SW846 8270C SIM

Benzo[a] pyrene

Dibenz[a,h]anthracene

Surrogate: Nitrobenzene-d5 Surrogate: 2-Fluorobiphenyl Surrogate: $p$-Terphenyl-d14

\section{9}

10.9

$72 \%$

$73 \%$

$63 \%$

10.9

10.9

23-120

30-115

18-137 $\begin{array}{llllll}\text { ug/kg dry } & 1 & \text { L201245 } & 01 / 23 / 2012 & 01 / 27 / 2012 & 8270 \mathrm{C} \text { SIM }\end{array}$

$\begin{array}{llllll}\mathrm{ug} / \mathrm{kg} \text { dry } & 1 & \mathrm{~L} 201245 & 01 / 23 / 2012 & 01 / 27 / 2012 & 8270 \mathrm{C} \text { SIM }\end{array}$

L201245 $01 / 23 / 2012 \quad 01 / 27 / 2012 \quad 8270$ C SIM

L201245 $01 / 23 / 2012 \quad 01 / 27 / 2012 \quad 8270$ C SIM

L201245 $01 / 23 / 2012 \quad 01 / 27 / 2012 \quad 8270$ C SIM 
Fax: 610-280-3041

National Security Technologies, LLC

M/S NTS025, PO Box 98521

Las Vegas NV, 89193-8521
Project: Miscellaneous

Project Number: V3701

Project Manager: Accounts Payable
Reported:

01/31/2012 13:41

\section{2-60-05-V7}

1201051-02 (Soil)

\begin{tabular}{|lllllll}
\hline & & Reporting & & & & \\
Analyte & Result and Qualifier & Limit & Units & Dilution & Batch & Prepared \\
\hline
\end{tabular}

\section{Lionville Laboratory}

Semivolatile Organic Compounds by SW846 8270C SIM

\section{Benzo[a] pyrene}

Dibenz[a,h]anthracene

Surrogate: Nitrobenzene-d5

Surrogate: 2-Fluorobiphenyl

Surrogate: p-Terphenyl-d14

$\begin{array}{lll}10.6 & \mathrm{U} & 10.6 \\ 10.6 & \mathrm{U} & 10.6 \\ 76 \% & & 23-120 \\ 84 \% & & 30-115 \\ 64 \% & & 18-137\end{array}$

$\begin{array}{lllllll}10.6 & \text { ug/kg dry } & 1 & \text { L201245 } & 01 / 23 / 2012 & 01 / 27 / 2012 & 8270 \text { C SIM } \\ 10.6 & \text { ug/kg dry } & 1 & \text { L201245 } & 01 / 23 / 2012 & 01 / 27 / 2012 & 8270 \text { C SIM } \\ 23-120 & & & L 201245 & 01 / 23 / 2012 & 01 / 27 / 2012 & 8270 \text { C SIM } \\ 30-115 & & & L 201245 & 01 / 23 / 2012 & 01 / 27 / 2012 & 8270 \text { C SIM } \\ 18-137 & & & L 201245 & 01 / 23 / 2012 & 01 / 27 / 2012 & 8270 \text { C SIM }\end{array}$


264 Welsh Pool Road Exton, PA 19341

Phone: 610-280-3000

Fax: 610-280-3041

National Security Technologies, LLC

M/S NTS025, PO Box 98521

Las Vegas NV, 89193-8521
Project: Miscellaneous

Project Number: V3701

Project Manager: Accounts Payable
Reported:

01/31/2012 13:41

\section{2-60-05-V8}

1201051-03 (Soil)

\begin{tabular}{|lllllll}
\hline & & Reporting & & & & \\
Analyte & Result and Qualifier & Limit & Units & Dilution & Batch & Prepared \\
\hline
\end{tabular}

\section{Lionville Laboratory}

Semivolatile Organic Compounds by SW846 8270C SIM

\section{Benzo[a] pyrene}

Dibenz[a,h]anthracene

Surrogate: Nitrobenzene-d5

Surrogate: 2-Fluorobiphenyl

Surrogate: p-Terphenyl-d14

$\begin{array}{lll}\mathbf{5 4 8} & \text { D } & 20.7 \\ \mathbf{1 6 2} & \mathrm{D} & 20.7 \\ 69 \% & & 23-120 \\ 78 \% & & 30-115 \\ 57 \% & & 18-137\end{array}$

$\begin{array}{lccccc}\text { ug/kg dry } & 2 & \text { L201245 } & 01 / 23 / 2012 & 01 / 27 / 2012 & 8270 \mathrm{C} \\ \text { ug/kg dry } & 2 & \text { L201245 } & 01 / 23 / 2012 & 01 / 27 / 2012 & 8270 \mathrm{C} \\ & & & & & \text { SIM } \\ & & \text { L201245 } & 01 / 23 / 2012 & 01 / 27 / 2012 & 8270 \text { C SIM } \\ & & \text { L201245 } & 01 / 23 / 2012 & 01 / 27 / 2012 & 8270 \text { C SIM } \\ & & \text { L201245 } & 01 / 23 / 2012 & 01 / 27 / 2012 & 8270 \text { C SIM }\end{array}$

L201245 01/23/2012 01/27/2012 8270C SIM 


\section{ORGANIC ANALYSIS DATA SHEET}

\section{2}

25-60-04-V1

Laboratory: Lionville Laboratory

Client:

National Security Technologies, LLC

Matrix: $\quad \underline{\text { Soil }}$

Sampled:

$\underline{03 / 01 / 12 ~ 12: 05}$

Solids:

$\underline{95.66}$

Batch:
Laboratory ID:

Prepared:

Preparation:
SDG:

Project:

1203012-01

$\underline{03 / 02 / 12 ~ 14: 09}$

SW $3540 \mathrm{C}$
SDG \#V3716

BOA Contract

File ID:

Analyzed:

Initial/Final:
LIMS_EXPORT2527

03/05/12 19:57

$31.47 \mathrm{~g} / 10 \mathrm{~mL}$ $+203019$ Sequence:

2030037

CAS NO. Calibration: UNASSIGNED Instrument: $\underline{\mathrm{GC} 17}$

11097-69-1

11096-82-5

COMPOUND

Aroclor 1254

Aroclor 1260

4

\begin{tabular}{c|c}
\hline & DILUTION \\
\hline & 1 \\
\hline
\end{tabular}

1
CONC. (ug/kg dry) 73.5 13.3

\begin{tabular}{|l|c|c|c|c|c|}
\hline SYSTEM MONITORING COMPOUND & ADDED (ug/kg dry) & CONC (ug/kg dry) & $\%$ REC & QC LIMITS & Q \\
\hline Decachlorobiphenyl & 33.216 & 31.9 & 96 & $43-144$ & \\
\hline Tetrachloro-meta-xylene & 33.220 & 31.2 & 94 & $52-141$ & \\
\hline
\end{tabular}

* Value outside of QC limits 


\section{ORGANIC ANALYSIS DATA SHEET 8082}

Laboratory: Lionville Laboratory

Client: .

Matrix: $\quad \underline{\text { Soil }}$

Sampled:

$\underline{03 / 01 / 1212: 10}$

Solids:

$\underline{96.19}$

Batch:
SDG:

Project:

Laboratory ID:

Prepared:

Preparation:
1203012-02

$\underline{03 / 02 / 12 ~ 14: 09}$

SW $3540 \mathrm{C}$ $\underline{\text { SDG \#V3716 }}$

BOA Contract

File ID:

Analyzed: $\quad \underline{03 / 05 / 1221: 56}$

Initial/Final: $\quad 30.07 \mathrm{~g} / 10 \mathrm{~mL}$

\begin{tabular}{|c|l|c|c|c|}
\hline CAS NO. & COMPOUND & DILUTION & CONC. (ug/kg dry) & Q \\
\hline $11097-69-1$ & Aroclor 1254 & 40 & 3030 & UNASSIGNED Instrument: \\
\hline $11096-82-5$ & Aroclor 1260 & 40 & 342 & GC17 \\
\hline
\end{tabular}

\begin{tabular}{|l|c|c|c|c|c|}
\hline SYSTEM MONITORING COMPOUND & ADDED (ug/kg dry) & CONC (ug/kg dry) & \% REC & QC LIMITS & Q \\
\hline Decachlorobiphenyl & 34.574 & 48.9 & 142 & $43-144$ & D \\
\hline Tetrachloro-meta-xylene & 34.577 & 45.9 & 133 & $52-141$ & D \\
\hline
\end{tabular}

* Value outside of QC limits 
Laboratory: Lionville Laboratory

Client:

Matrix:

Sampled:

National Security Technologies, LLC

Soil

Solids:

$\underline{03 / 01 / 12 ~ 12: 15 ~}$

95.80

Batch:

CAS NO.

11097-69-1

$11096-82-5$

I 2030
Laboratory ID:

Prepared:

Preparation:
SDG:

Project:

$\underline{1203012-03}$

$\underline{03 / 02 / 1214: 09}$

SW 3540C

\section{$\underline{\text { SDG \#V3716 }}$}

BOA Contract

File ID:

Analyzed:

LIMS_EXPORT2648

Initial/Final: $\underline{03 / 06 / 12 ~ 07: 53}$

$31.57 \mathrm{~g} / 10 \mathrm{~mL}$ UNASSIGNED Instrument: $\underline{\mathrm{GC} 17}$

\begin{tabular}{|l|c|c|c|c|c|}
\hline SYSTEM MONITORING COMPOUND & ADDED (ug/kg dry) & CONC (ug/kg dry) & $\%$ REC & QC LIMITS & Q \\
\hline Decachlorobiphenyl & 33.063 & 37.2 & 112 & $43-144$ & \\
\hline Tetrachloro-meta-xylene & 33.066 & 35.2 & 106 & $52-141$ & \\
\hline
\end{tabular}

* Value outside of QC limits 
ORGANIC ANALYSIS DATA SHEET

8082

\begin{tabular}{|c|c|c|c|c|c|c|c|c|}
\hline Laboratory: & \multicolumn{3}{|c|}{ Lionville Laboratory } & \multirow{2}{*}{\multicolumn{2}{|c|}{$\begin{array}{l}\text { SDG: } \\
\text { Project: }\end{array}$}} & \multicolumn{3}{|l|}{$\underline{\text { SDG \# } 3719}$} \\
\hline Client: & \multicolumn{3}{|c|}{ National Security Technologies, LLC } & & & \multicolumn{3}{|l|}{$\underline{\text { BOA Contract }}$} \\
\hline Matrix: & $\underline{\text { Soil }}$ & & Laboratory ID: & \multicolumn{2}{|c|}{$\underline{1203057-01}$} & File ID: & \multicolumn{2}{|c|}{ Lims_export2743 } \\
\hline Sampled: & $\underline{03 / 13 / 1208: 25}$ & & Prepared: & \multicolumn{2}{|c|}{$\underline{03 / 14 / 1214: 23}$} & Analyzed: & \multicolumn{2}{|l|}{$\underline{03 / 16 / 12 ~ 12: 04}$} \\
\hline Solids: & $\underline{94.49}$ & & Preparation: & \multicolumn{2}{|c|}{$\underline{\mathrm{SW} 3540 \mathrm{C}}$} & Initial/Final: & \multicolumn{2}{|l|}{$30.24 \mathrm{~g} / 10 \mathrm{~mL}$} \\
\hline Batch: & $\underline{\mathrm{L} 203} 123$ & Sequence: & $\underline{2030096}$ & & Calibration: & UNASSIGNED & Instrument: & $\underline{\mathrm{GC} 15}$ \\
\hline CAS NO. & \multicolumn{4}{|l|}{ COMPOUND } & DILUTION & \multicolumn{2}{|c|}{ CONC. (ug/kg dry) } & Q \\
\hline $11097-69-1$ & \multicolumn{4}{|l|}{ Aroclor 1254} & 1 & \multicolumn{2}{|c|}{20.0} & \\
\hline \multicolumn{3}{|c|}{ SYSTEM MONITORING COMPOUND } & \multicolumn{2}{|c|}{ ADDED (ug/kg dry) } & CONC (ug/kg dry) & $\%$ REC & QC LIMITS & Q \\
\hline \multicolumn{3}{|c|}{ Decachlorobiphenyl } & \multicolumn{2}{|c|}{34.998} & 25.2 & 72 & $43-144$ & \\
\hline \multicolumn{3}{|c|}{ Tetrachloro-meta-xylene } & \multicolumn{2}{|c|}{35.002} & 29.7 & 85 & $52-141$ & \\
\hline
\end{tabular}

* Value outside of QC limits 
ORGANIC ANALYSIS DATA SHEET 8082

Laboratory: Lionville Laboratory

Client: National Security Technologies, LLC

Matrix: $\quad \underline{\text { Soil }}$

Sampled: $\quad \underline{03 / 13 / 1208: 35}$

Solids:

$\underline{95.36}$

$\underline{\mathrm{L} 203} \underline{123}$
SDG:

Project:

Laboratory ID:

Prepared:

Preparation: $\quad$ SW $3540 \mathrm{C}$ $\underline{1203057-02}$

$\underline{03 / 14 / 1214: 23}$
Batch: Sequence: 2030096 $\underline{\text { SDG \# } 3719}$

BOA Contract

File ID:

Lims_export 2750

Analyzed: $\quad \underline{03 / 16 / 1212: 42}$

Initial/Final: $\quad \underline{31.08 \mathrm{~g} / 10 \mathrm{~mL}}$

\begin{tabular}{|c|l|c|c|c|}
\hline CAS NO. & COMPOUND & DILUTION & CONC. (ug/kg dry) & Q \\
\hline $11097-69-1$ & Aroclor 1254 & 1 & 13.5 & UNASSIGNED Instrument: \\
\hline
\end{tabular}

\begin{tabular}{|l|c|c|c|c|c|}
\hline SYSTEM MONITORING COMPOUND & ADDED (ug/kg dry) & CONC (ug/kg dry) & $\%$ REC & QC LIMITS & Q \\
\hline Decachlorobiphenyl & 33.742 & 33.9 & 101 & $43-144$ & \\
\hline Tetrachloro-meta-xylene & 33.745 & 26.0 & 77 & $52-141$ & \\
\hline
\end{tabular}

* Value outside of QC limits 


\section{ORGANIC ANALYSIS DATA SHEET}

\section{2}

Laboratory: Lionville Laboratory

Client: National Security Technologies, LLC

Matrix: Soil

Sampled: $\quad \underline{03 / 13 / 1208: 30}$

Solids:

$\underline{95.15}$

Batch:
SDG:

Project:

Laboratory ID:

Prepared:

Preparation: $\quad$ SW $3540 \mathrm{C}$
SDG \# 3719

BOA Contract

File ID:

Lims_export2751

Analyzed: $\quad \underline{03 / 16 / 1213: 21}$

Initial/Final: $\quad \underline{30.04 \mathrm{~g} / 10 \mathrm{~mL}}$

\begin{tabular}{|c|c|c|c|c|c|}
\hline Batch: & $\underline{\mathrm{L} 203123}$ & $\quad 2030096$ & Calibration: & UNASSIGNED Instrument: & $\underline{\mathrm{GC} 15}$ \\
\hline CAS NO. & COMPOUND & & DILUTION & CONC. (ug/kg dry) & $Q$ \\
\hline $11097-69-1$ & Aroclor 1254 & & 1 & 14.0 & $\mathrm{U}$ \\
\hline
\end{tabular}

\begin{tabular}{|l|c|c|c|c|c|}
\hline SYSTEM MONITORING COMPOUND & ADDED (ug/kg dry) & CONC (ug/kg dry) & $\%$ REC & QC LIMITS & Q \\
\hline Decachlorobiphenyl & 34.984 & 31.2 & 89 & $43-144$ & \\
\hline Tetrachloro-meta-xylene & 34.987 & 22.0 & 63 & $52-141$ & \\
\hline
\end{tabular}

* Value outside of QC limits 
Revision: 0

Date: August 2012

\section{APPENDIX C}

WASTE DISPOSITION DOCUMENTATION 
CAU 562 Closure Report

Section: Appendix C

Revision: 0

Date: August 2012

\section{THIS PAGE INTENTIONALLY LEFT BLANK}




\begin{tabular}{|c|c|c|c|}
\hline \multicolumn{2}{|l|}{ SWO USE (Select One) } & 23 & $\sqrt{6}$ \\
\hline
\end{tabular}

For waste characterization, approval, and/or assistance, contact Solid Waste Operation (SWO) at 5-7898.

\section{REQUIRED: WASTE GERERATOR INFORMATION}

(This form is for rolloffs, dump trucks, and other onsite disposal of materials.)

Waste Generator: Rebecca King

Phone Number: 5-5804

Location / Origin: CAU 562, Waste Systems, Area 2 CAS 02-59-01

Waste Category: (check one)

Waste Type:

(check one) $\square$ Non-Putrescible $\square$ Asbestos Containing Material

$\square$ Commercial

$\square$ Putrescrible

$\bigotimes$ Industrial

Pollution Prevention Category: (check one) $\$ Environmental management

Pollution Prevention Category: (check one) $\bigotimes$ Clean-Up

Method of Characterization: (check one)

$\triangle$ Sampling \& Analysis

$\bigotimes$ FFACO-onsite

$\square$ FFACO-offsite

$\square$ Defense Projects

$\square$ Routine

Prohibited Waste at all three

NTS landfills:

Additional Prohibited Waste

at the Area 9 U10C Landfill:

Radioactive waste; RCRA waste; Hazardous waste; Free liquids,
levels, and Medical wastes (needles, sharps, bloody clothing).

Sewage Sludge, Animal carcasses, Wet garbage (food waste); and Friable asbestos

\section{REQUIRED: WASTE CONTENTS ALLOWABLE WASTES \\ Check all allowable wastes that are contained within this load:}

NOTE: Waste disposal at the Area 6 Hydrocarbon Landfill must have come into contact with petroleum hydrocarbons or coolants, such as: gasoline (no benzene, lead); jet fuel; diesel fuel; lubricants and hydraulics; kerosene; asphaltic petroleum hydrocarbon; and ethylene glycol.

Acceptable waste at any NTS landfill: $\square$ Paper
$\square$ Asphalt
$\bigotimes$ Metal
$\square$ Wood
$\bigotimes$ Soil
$\triangle$ Rocks / unaltered geologic materials
$\square$ Rubber (excluding tires)
Plastic $\square$ Wire
Cable
$\square$ Cloth
$\square$ Insulation (non-Asbestosform)

Manufactured items: (swamp coolers, furniture, rugs, carpet, electronic components, PPE, etc.)

Additional waste accepted at the Area 23 Mercury Landfill: $\square$ Office Waste
$\square$ Asbestos $\square$ Friable $\square$ Non-Friable (contact SWO if regulated load)

$\square$ Food Waste

Quantity:

\section{Additional waste accepted at the Area 9 U10c Landfill:}
$\square$ Non-friable asbestos
Light ballasts (contact SWO)
Hydrocarbons (contact SWO)
$\square$ Drained automobiles and military vehicles
Drained fuel filters (gas \& diesel)
Other

Solid fractions from sand/oil/water

$\triangle$ Deconned Underground and Above Ground Tanks

Additional waste accepted at the Area 6 Hydrocarbon Landfill:

$\square$ Septic sludge
$\square$ Plants
$\square$ Sags

$\square$ Drained fuel filters (gas \& diesel)

$\square$ Sludge from sand/oil/water separators REQUIRED: WASTE GENERATOR SIGNATURE

Crushed non-teme plated oil filters PCBs below 50 parts per million

Initials: . (if initialed, no radiological clearance is necessary.)

The above mentioned waste was generated outside of a Controlled Waste Management Area (CWMA) and to the best of my knowledge, does not contain radiological materials.

To the best of my knowledge, the waste described above contains only those materials that are allowed for disposal at this site. I have verified this through the waste characterization method identified above and a review of the above-mentioned prohibited and allowable waste items. I have contacted Property Management and have verified that this material/equipment is approved for disposal in the landfill.

Print Name: Brian Konrad

Signature: /s/: Signature on File Date: $12 / 08 / 11$

Note: "Food waste, office trash and animal carcasses do not require a radiological clea must have signed removal certification statement with Load Verification."

SWO USE ONLY

Load Weight (net from scalejor estimate): $2,200 /$ Signature of Certifier:

Radiological Survey Release for Waste Disposal RCT Initials

- This container/load meets the criteria for no added man-made radioactive material This container/load meets the criteria for Radcon Manual Table 4.2 release limits. This container/load is exempt from survey due to proce\$s knowledge and origin. SIGNATURE:/s/: Signature on File DATE: $(2-\gamma \cdot)$ 
For waste characterization, approval, and/or assistance, contact Solid Waste Operation (SWO) at 5-7898.

REQUIRED: WASTE GERERATOR INFORMATION

(This form is for rolloffs, dump trucks, and other onsite disposal of materials.)

Waste Generator: Rebecca King

Phone Number: $5-5804$

Location / Origin: CAU 562, Waste Systems, Area 2 CAS 02-59-01

\begin{tabular}{|c|c|c|c|}
\hline Waste Category: (check ongol & $\square$ Commercial & $\triangle$ Industrialp & \\
\hline $\begin{array}{l}\text { Waste Type: } \\
\text { (check one) }\end{array}$ & $\begin{array}{l}\square \text { Putrescrible } \\
\square \text { Asbestos Containing Materiak }\end{array}$ & $\begin{array}{l}\text { FFACO-onsite } \\
\text { FFACO-offsite }\end{array}$ & $\begin{array}{l}\square \text { WAC Exception } \\
\square \text { Historic DOE/NV }\end{array}$ \\
\hline Pollution Prevention Category: (check one) & $\triangle$ Environmental management & $\square$ Defense Projects & $\square \mathrm{YMP}$ \\
\hline Pollution Prevention Category: (check one) & $\triangle$ Clean-Up & $\square$ Routine & \\
\hline Method of Characterization: (check one) & $\triangle$ Sampling \& Analysis & $\square$ Process Knowledge & $\square$ Contents \\
\hline
\end{tabular}

Prohibited Waste at all three Radioactive waste; RCRA waste; Hazardous waste; Free liquids, PCBs above TSCA regulatory NTS landfills:

Additional Prohibited Waste at the Area 9 U10C Landfill:

levels, and Medical wastes (needles, sharps, bloody clothing).

Sewage Sludge, Animal carcasses, Wet garbage (food waste); and Friable asbestos

REQUIRED: WASTE CONTENTS ALLOWABLE WASTES

Check all allowable wastes that are contained within this load:

NOTE: Waste disposal at the Area 6 Hydrocarbon Landfill must have come into contact with petroleum hydrocarbons or coolants, such as: gasoline (no benzene, lead); jet fuel; diesel fuel; lubricants and hydraulics; kerosene; asphaltic petroleum hydrocarbon; and ethylene glycol.
Acceptable waste at any NTS landfill:
$\square$ Paper
$\triangle$ Rocks / unaltered geologic materials
$\triangle$ Soil
$\square$ Rubber (excluding tires)
$\square$ Asphalt
$\otimes$ Metal
$\square$ Wood
$\square$ Cloth
$\square$ Insulation (non-Asbestosform)
Empty containers
Cable
$\square$ Demolition debris
$\bigotimes$ Cement \& concrete

$\square$ Manufactured items: (swamp coolers, furniture, rugs, carpet, electronic components, PPE, etc.)
Additional waste accepted at the Area 23 Mercury Landfill:
$\square$ Office Waste
$\square$ Food Waste
Animal Carcasses
Quantity:

Asbestos

Friable

$\square$ Non-Friable (contact SWO if regulated load)

\section{Additional waste accepted at the Area 9 U10c Landfill:}
$\square$ Non-friable asbestos
$\square$ Drained automobiles and military vehicles
Light ballasts (contact SWO)
Drained fuel filters (gas \& diesel)
Hydrocarbons (contact SWO)
Other

Solid fractions from sand/oil/water

$\otimes$ Deconned Underground and Above Ground Tanks

Additional waste accepted at the Area 6 Hydrocarbon Landfill:
$\bigotimes$ Septic sludge
$\square$ Rags
$\square$ Drained fuel filters (gas \& diesel)
Crushed non-teme plated oil filters
Plants $\square$ Soil
$\square$ Sludge from sand/oil/water separators
PCBs below 50 parts per million REQUIRED: WASTE GENERATOR SIGNATURE

Initials: _ _ (if initialed, no radiological clearance is necessary.)

The above mentioned waste was generated outside of a Controlled Waste Management Area (CWMA) and to the best of my knowledge, does not contain radiological materials.

To the best of my knowledge, the waste described above contains only those materials that are allowed for disposal at this site. I have verified this through the waste characterization method identified above and a review of the above-mentioned prohibited and allowable waste items. I have contacted Property Management and have verified that this material/eguipment is approved for disposal in the landfill.

Print Name: Brian Konrad

Signature: /s/: Signature on File Date: $12 / 08 / 11$

Note: "Food waste, office trash and animal carcasses do not require a radiological clear must have signed removal certification statement with Load Verification."

\section{SWO USE ONLY}

Load Weight (net frod scale $\partial$ r estimate): $23,740 \sqrt{ }$ Signature of Certifier:

Radiological Survey Release for Waste Disposal RCT Initials

This container/load meets the criteria for no added man-made radioactive material This container/load meets the criteria for Radcon Manual Table 4.2 release limits. This container/load, is exempt from survey due to process $/ \mathrm{knoy} / \mathrm{le} / \mathrm{dge}$ and origin. 


\begin{tabular}{llllll}
\hline SWO USE (Select One) & AREA & $\square 23$ & $\bigotimes 6$ & $\bigotimes 9 / 10 \mathrm{C}$ & LANDFILL
\end{tabular}

For waste characterization, approval, and/or assistance, contact Solid Waste Operation (SWO) at 5-7898.

\section{REQUIRED: WASTE GERERATOR INFORMATION}

(This form is for rolloffs, dump trucks, and other onsite disposal of materials.)

Waste Generator: Rebecca King

Phone Number: 5-5804

Location / Origin: CAU 562, Waste Systems, Area 2 CAS 02-59-01

\begin{tabular}{|c|c|c|c|}
\hline Waste Category: (check one) & $\square$ Commercial & $\bigotimes$ Industrial & \\
\hline Waste Type: & $\square$ Putrescrible & $\triangle$ FFACO-onsite & $\square$ WAC Exception \\
\hline$\square$ Non-Putrescible & $\square$ As'bestos Containing Material & $\square$ FFACO-offsite & $\square$ Historic DOE/NV \\
\hline Pollution Prevention Category: (check one) & $\triangle$ Environmental management & $\square$ Defense Projects & $\square$ YMP \\
\hline Pollution Prevention Category: (check one) & $\triangle$ Clean-Up & $\square$ Routine & \\
\hline Method of Characterization: (check one) & $\triangle$ Sampling \& Analysis & $\square$ Process Knowledge & $\square$ Contents \\
\hline
\end{tabular}

Prohibited Waste at all three

NTS landfills:

Additional Prohibited Waste at the Area 9 U10C Landfill:

Radioactive waste; RCRA waste; Hazardous waste; Free liquids, PCBs above TSCA regulatory levels, and Medical wastes (needles, sharps, bloody clothing).

Sewage Sludge, Animal carcasses, Wet garbage (food waste); and Friable asbestos

\section{REQUIRED: WASTE CONTENTS ALLOWABLE WASTES}

Check all allowable wastes that are contained within this load:

NOTE: Waste disposal at the Area 6 Hydrocarbon Landfill must have come into contact with petroleum hydrocarbons or coolants, such as: gasoline (no benzene, lead); jet fuel; diesel fuel; lubricants and hydraulics; kerosene; asphaltic petroleum hydrocarbon; and ethylene glycol.
Acceptable waste at any NTS landfill:
$\square$ Paper
$\bigotimes$ Rocks / unaltered geologic materials
$\square$ Empty containers
$\square$ Asphalt
$\bigotimes$ Metal
$\square$ Wood
$\triangle$ Soil
$\square$ Rubber (excluding tires)
$\square$ Demolition debris
$\square$ Plastic
$\square$ Cable
$\square$ Cloth
Insulation (non-Asbestosform)
$\bigotimes$ Cement \& concrete

$\square$ Manufactured items: (swamp coolers, furniture, rugs, carpet, electronic components, PPE, etc.)

Additional waste accepted at the Area 23 Mercury Landfill: $\square$ Office Waste $\square$ Food Waste $\square$ Animal Carcasses
Asbestos
Friable
Non-Friable (contact SWO if regulated load)
Quantity:

Additional waste accepted at the Area 9 U10c Landfill:
$\square$ Non-friable asbestos
$\square$ Drained automobiles and military vehicles
$\square$ Light ballasts (contact SWO)
$\square$ Drained fuel filters (gas \& diesel)
$\square$ Hydrocarbons (contact SWO)
Other

Solid fractions from sand/oil/water

$凶$ Deconned Underground and Above Ground Tanks

\begin{tabular}{|c|c|c|c|}
\hline \multicolumn{4}{|c|}{ Additional waste accepted at the Area 6 Hydrocarbon Landfill: $\square$} \\
\hline$\bigotimes$ Septic sludge & $\square$ Rags & $\square$ Drained fuel filters (gas \& diesel) & $\square$ Crushed non-teme plated oil filters \\
\hline$\square$ Plants & $\square$ Soil & $\square$ Sludge from sand/oil/water separators & $\square$ PCBs below 50 parts per million \\
\hline
\end{tabular}

Initials: _ _ (if initialed, no radiological clearance is necessary.)

The above mentioned waste was generated outside of a Controlled Waste Management Area (CWMA) and to the best of my knowledge, does not contain radiological materials.

To the best of my knowledge, the waste described above contains only those materials that are allowed for disposal at this site. I have verified this through the waste characterization method identified above and a review of the above-mentioned prohibited and allowable waste items. I have contacted Property Management and have verified that this material/eauidment is approved for disposal in the landfill.

Print Name: Brian Konrad

Signature: /s/: Signature on File

Date: $12 / 08 / 11$

Note: "Food waste, office trash and animal carcasses do not require a radiological clec must have signed removal certification statement with Load Verification."

SWO USE ONLY

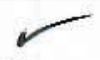
Load Weight (net from scale or estimate): 21,320 Signature of Certifier: $1 \mathrm{~s} /$ : Signature on File

Radiological Survey Release for Waste Disposal RCT Initials

This container/load meets the criteria for no added man-made radioactive material This container/load meets the criteria for Radcon Manual Table 4.2 release limits. This container/load is exempt from survey due torocess knowledge and origin.

SIGNATURE:/s/: Signature on File DATE: / $/ 2 \cdot \gamma \cdot 1 /$ FRM-0646 (08/06) 


\begin{tabular}{llllll}
\hline SWO USE (Select One) & AREA & $\square 23$ & {$[16$} & 9/10C & LANDFILL
\end{tabular}

For waste characterization, approval, and/or assistance, contact Solid Waste Operation (SWO) at 5-7898.

\section{REQUIRED: WASTE GERERATOR INFORMATION}

(This form is for rolloffs, dump trucks, and other onsite disposal of materials.)

Waste Generator: Rebecca King

Phone Number: 5-5804

Location / Origin: CAU 562, Waste Systems, Area 2 CAS 02-59-01

\begin{tabular}{|c|c|c|c|}
\hline Waste Category: (check one) & $\square$ Commercial & $\otimes$ Industrial & \\
\hline Waste Type: & $\square$ Putrescrible & $\triangle$ FFACO-onsite & $\square \mathrm{W}$ \\
\hline Non-Putrescible & $\square$ Asbestos Containing Material & $\square$ FFACO-offsite & $\square$ Historic DOE/NV \\
\hline Pollution Prevention Category: (check one) & $\triangle$ Environmental management & $\square$ Defense Projects & $\square \mathrm{YMP}$ \\
\hline Pollution Prevention Category: (check one) & $\triangle$ Clean-Up & $\square$ Routine & \\
\hline lethod of Char: & ampling \& Analysis & $\square$ Process $\mathrm{K}$ & \\
\hline
\end{tabular}

Prohibited Waste at all three Radioactive waste; RCRA waste; Hazardous waste; Free liquids, PCBs above TSCA regulatory NTS landfills:

Additional Prohibited Waste at the Area 9 U10C Landfill: levels, and Medical wastes (needles, sharps, bloody clothing).

Sewage Sludge, Animal carcasses, Wet garbage (food waste); and Friable asbestos

REQUIRED: WASTE CONTENTS ALLOWABLE WASTES

Check all allowable wastes that are contained within this load:

NOTE: Waste disposal at the Area 6 Hydrocarbon Landfill must have come into contact with petroleum hydrocarbons or coolants, such as: gasoline (no benzene, lead); jet fuel; diesel fuel; lubricants and hydraulics; kerosene; asphaltic petroleum hydrocarbon; and ethylene glycol.
Acceptable waste at any NTS landfill:
$\square$ Paper
$\bigotimes$ Rocks / unaltered geologic materials
$\square$ Empty containers
$\square$ Asphalt
$\otimes$ Metal
$\square$ Wood
$\triangle$ Soil
$\square$ Rubber (excluding tires)
$\square$ Demolition debris
$\square$ Plastic
Wire
$\square$ Cable
$\square$ Cloth
$\square$ Insulation (non-Asbestosform)
$\bigotimes$ Cement \& concrete

Manufactured items: (swamp coolers, furniture, rugs, carpet, electronic components, PPE, etc.)
Additional waste accepted at the Area 23 Mercury Landfill:
$\square$ Office Waste
$\square$ Food Waste
Animal Carcasses
Asbestos
Friable
Non-Friable (contact SWO if regulated load)
Quantity:

Additional waste accepted at the Area 9 U10c Landfill:
$\square$ Non-friable asbestos
$\square$ Drained automobiles and military vehicles
$\square$ Light ballasts (contact SWO)
Drained fuel filters (gas \& diesel)
$\square$ Hydrocarbons (contact SWO
Other

Solid fractions from sand/oil/water

$\bigotimes$ Deconned Underground and Above Ground Tanks

Additional waste accepted at the Area 6 Hydrocarbon Landfill:
$\bigotimes$ Septic sludge
$\square$ Rags
$\square$ Drained fuel filters (gas \& diesel)
Crushed non-teme plated oil filters
Plants
Soil
$\square$ Sludge from sand/oil/water separators REQUIRED: WASTE GENERATOR SIGNATURE

Initials: _ _ (if initialed, no radiological clearance is necessary.)

The above mentioned waste was generated outside of a Controlled Waste Management Area (CWMA) and to the best of my knowledge, does not contain radiological materials.

To the best of my knowledge, the waste described above contains only those materials that are allowed for disposal at this site. I have verified this through the waste characterization method identified above and a review of the above-mentioned prohibited and allowable waste items. I have contacted Property Management and have verified that this material/equipment is approved for disposal in the landfill.

Print Name: Brian Konrad

Signature: /s/: Signature on File

Date: $12 / 08 / 11$

Note: "Food waste, office trash and animal carcasses do not require a radiological c must have signed removal certification statement with Load Verification."

SWO USE ONLY

Load Weight (net from scale or estimate)

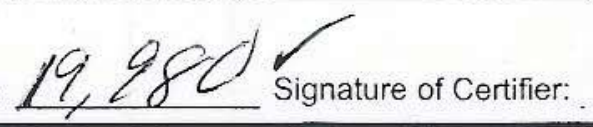

Radiological Survey Release for Waste Disposa RCT Initials

This container/load meets the criteria for no added man-made radioactive material This container/load meets the criteria for Radcon Manual Table 4.2 release limits. This container/load is exempt from survey due to process knówleddae and origin. /) \& /, SIGNATURE:/S/: Signature on File

s/: Signature on File 
SWO USE (Select One) AREA

23

X 6

9/10C

LANDFILL

For waste characterization, approval, and/or assistance, cóntact Solid Waste Operation (SWO) at 5-7898. REQUIRED: WASTE GERERATOR INFORMATION

(This form is for rolloffs, dump trucks, and other onsite disposal of materials.)

Waste Generator: Rebreca Kiar a

Phone Number: $5 \cdot 5804$

Location / Origin: CAU 56 What

Waste Category: (check one)

Waste Type:

(check one)

15. तTS $\$ 8$

$\square$ Non-Putrescible

$\square$ Commercial
$\square$ Putrescrible
$\square$ Asbestos Containing Material

Pollution Prevention Category: (check one) $\square$ Environmental management

Pollution Prevention Category: (check one)

Method of Characterization: (check one)

Q Clean-Up

Q Sampling \& Analysis

7 i $0^{3} 2-58-0$,

Prohibited Waste at all three Radioactive waste; RCRA waste; Hazardous waste; Free liquids, PCBs above TSCA regulatory NTS landfills:

Additional Prohibited Waste

at the Area 9 U10C Landfill:

levels, and Medical wastes (needles, sharps, bloody clothing).

Sewage Sludge, Animal carcasses, Wet garbage (food waste); and Friable asbestos

\section{REQUIRED: WASTE CONTENTS ALLOWABLE WASTES}

Check all allowable wastes that are contained within this load:

NOTE: Waste disposal at the Area 6 Hydrocarbon Landfill must have come into contact with petroleum hydrocarbons or coolants, such as: gasoline (no benzene, lead); jet fuel; diesel fuel; lubricants and hydraulics; kerosene; asphaltic petroleum hydrocarbon; and ethylene glycol.
Acceptable waste at any NTS landfill:
$\square$ Paper
$\square$ Rocks / unaltered geologic materials
Empty containers
$\square$ Asphalt
Q Metal
$\square$ Wood
[ Soil
$\square$ Rubber (excluding tires)
$\square$ Demolition debris
Plastic $\square$ Wire
Cable
$\square$ Cloth
$\square$ Insulation (non-Asbestosform)
Q Cement \& concrete

Manufactured items: (swamp coolers, furniture, rugs, carpet, electronic components, PPE, etc.)

Additional waste accepted at the Area 23 Mercury Landfill: $\square$ Office Waste $\square$ Food Waste

Animal Carcasses

$\square$ Asbestos

Friable

$\square$ Non-Friable (contact SWO if regulated load)

Quantity:

Additional waste accepted at the Area 9 U10c Landfill:

$\square$ Non-friable asbestos

$\square$ Drained automobiles and military vehicles

Solid fractions from sand/oil/water

$\square$ Light ballasts (contact SWO)

$\square$ Drained fuel filters (gas \& diesel)

Hydrocarbons (contact SwO) $\square$ Other

$\square$ Deconned Underground and Above

Ground Tanks

Additional waste accepted at the Area 6 Hydrocarbon Landfill:
Q Septic sludge
$\square$ Rags
$\square$ Drained fuel filters (gas \& diesel)
Crushed non-teme plated oil filters
Plants
Soil
$\square$ Sludge from sand/oil/water separators PCBs below 50 parts per million REQUIRED: WASTE GENERATOR SIGNATURE

Initials: _ _ (if initialed, no radiological clearance is necessary.)

The above mentioned waste was generated outside of a Controlled Waste $N$ knowledge, does not contain radiological materials.

To the best of my knowledge, the waste described above contains only tho: site. I have verified this through the waste characterization method identifis prohibited and allowable waste items. I have contacted Property Managem is approved for disposal in the landfill

Print Name: PFLL E TZW

Signature: /s/: Signature on File

Date:

Radiological Survey Release for Waste Disposal RCT Initials

This container/load meets the criteria for no added man-made radioactive material This container/load meets the criteria for Radcon Manual Table 4.2 release limits.

1 This container/load is exempt from survey due to process bhowledge and origin.

SIGNATURE: /s/: Signature On FileDate: $12-13 \cdot v$

FRM-0646 (08/06)

Note: "Food waste, office trash and animal carcasses do not require a radiological clearance. Freon-containing appliances must have signed removal certification statement with Load Verification."

SWO USE ONLY

Load Weight (net from scale or estimate): $20,0 \mathrm{OS}$ Signature of Certifier: Is/: Signature on File 
Form

\begin{tabular}{llllll}
\hline SWO USE (Select One) & AREA & $\square 23$ & $\square 6$ & $\square 9 / 10 \mathrm{C}$ & LANDFILL
\end{tabular}

For waste characterization, approval, and/or assistance, contact Solid Waste Operation (SWO) at 5-7898. REQUIRED: WASTE GERERATOR INFORMATION

(This form is for rolloffs, dump trucks, and other onsite disposal of materials.)

Waste Generator: $R \varepsilon b \varepsilon \subset c A R$ ing Phone Number: $5^{-5}-504$ Location / Origin: CALSBZ, LVASE 5 Y

$\cos 42-59-01$

Waste Category: (check one) $\square$ Commercial

$\begin{array}{llll}\text { Waste Type: } & \square \text { NTS DS } & \square \text { Putrescrible } & \square \text { FFACO-onsite } \\ \text { (check one) } & \square \text { Non-Putrescible } & \square \text { Asbestos Containing Material } \square \text { FFACO-offsite } \quad \square \text { Historic DOE/NV }\end{array}$

Pollution Prevention Category: (check one) Environmental managemen

Pollution Prevention Category: (check one) $\triangle$ Clean-Up

Method of Characterization: (check one) $\square$ Sampling \& Analysis

$\square$ Defense Projects

YMP

Prohibited Waste at all three Radioactive waste; RCRA waste; Hazardous waste; Free liquids, PCBs above TSCA regulatory NTS landfills:

Additional Prohibited Waste

at the Area 9 U10C Landfill: levels, and Medical wastes (needles, sharps, bloody clothing).

Sewage Sludge, Animal carcasses, Wet garbage (food waste); and Friable asbestos

\section{REQUIRED: WASTE CONTENTS ALLOWABLE WASTES}

Check all allowable wastes that are contained within this load.

NOTE: Waste disposal at the Area 6 Hydrocarbon Landfill must have come into contact with petroleum hydrocarbons or coolants, such as: gasoline (no benzene, lead); jet fuel; diesel fuel; lubricants and hydraulics; kerosene; asphaltic petroleum hydrocarbon; and ethylene glycol.
Acceptable waste at any NTS landfill:
$\square$ Paper
$\square$ Rocks / unaltered geologic materials
$\square$ Empty containers
$\square$ Asphalt $\square$ Metal $\square$ Wood
Q Soil
$\square$ Rubber (excluding tires)
$\square$ Plastic $\square$ Wire
$\square$ Cable
$\square$ Cloth
$\square$ Insulation (non-Asbestosform)
$\square$ Demolition debris

Manufactured items: (swamp coolers, furniture, rugs, carpet, electronic components, PPE, etc.)
Additional waste accepted at the Area 23 Mercury Landfill: $\quad \square$ Office Waste
$\square$ Asbestos
Friable
Non-Friable (contact SWO if regulated load)
$\square$ Food Waste
Animal Carcasses
Quantity:

Additional waste accepted at the Area 9 U10c Landfill:

Solid fractions from sand/oil/water

Deconned Underground and Above Ground Tanks

\section{Additional waste accepted at the Area 6 Hydrocarbon Landfill:}
Weptic sludge
$\square$ Rags
$\square$ Drained fuel filters (gas \& diesel)
Plants
Soil
$\square$ Sludge from sand/oil/water separators
Crushed non-teme plated oil filters REQUIRED: WASTE GENERATOR SIGNATURE
PCBs below 50 parts per million

Initials: , . (if initialed, no radiological clearance is necessary.)

The above mentioned waste was generated outside of a Controlled Waste Management Area (CWMA) and to the best of my knowledge, does not contain radiological materials.

To the best of my knowledge, the waste described above contains only site. I have verified this through the waste characterization method ide prohibited and allowable waste items. I have contacted Property Mana is approved for disposal in the landfill.

Print Name: Pawk E DE

Signature: /s/: Signature on File

Date:

Note: "Food waste, office trash and animal carcasses do not require a r must have signed removal certification statement with Load Verif

Radiological Survey Release for Waste Disposal RCT Initials

This container/load meets the criteria for no added man-made radioactive material This container/load meets the criteria for Radcon Manual Table 4.2 release limits.

1 This container/load is exempt from survey due to proges thofvledge and origin.

SIGNATURE: /s/: Signature on File DATE: $12 \cdot 13 \cdot 1$

SWO USE ONLY

FRM-0646 (08/06)

Load Weight (net from scale or estimate): 


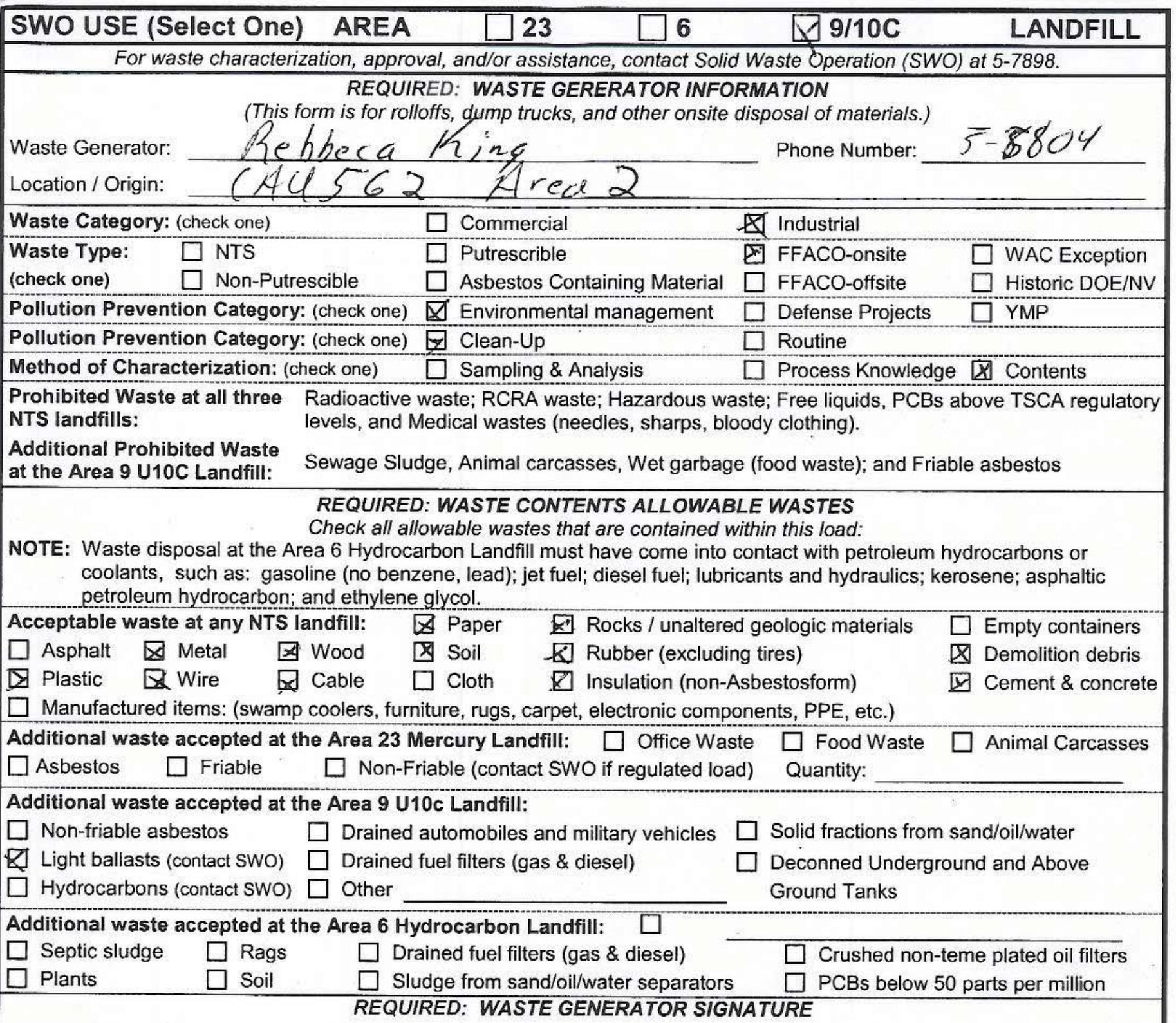

Initials: (if initialed, no radiological clearance is necessary.)

The above mentioned waste was generated outside of a Controlled Waste Management Area (CWMA) and to the best of my knowledge, does not contain radiological materials.

To the best of my knowledge, the waste described above contains only thos site. I have verified this through the waste characterization method identifie prohibited and allowable waste items. I have contacted Property Manageme is approved for disposal in the landfill.

Print Name:

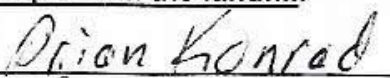

Signature: /s/: Signature on File

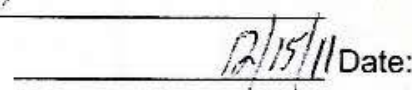

Radiological Survey Release for Waste Disposal RCT Initials

This container/load meets the criteria for no added man-made radioactive material This container/load meets the criteria for Radcon Manual Table 4.2 release limits. due to process shopledge and origin.

Note: "Food waste, office trash and animal carcasses do not require a radiolc must have signed removal certification statement with Load Verification."

SWO USE ONLY

Load Weight (net from scale ot estimate): $5,0, \infty \ldots$ Signature of Certifier: _s/: Signature on File SIGNATURE:/s/: Signature on $\frac{\text { File DATE: }[2-13 \cdot 1 /}{\text { FRM-0646 (08/06) }}$ 


\begin{tabular}{llllll}
\hline SWO USE (Select One) & AREA & $\square 23$ & $\square 6$ & $\square / 9 / 10 \mathrm{C}$ & LANDFILL
\end{tabular}

For waste characterization, approval, and/or assistance, contact Solid Waste Operation (SWO) at 5-7898. REQUIRED: WASTE GERERATOR INFORMATION

(This form is for rolloffs, dump trucks, and other onsite disposal of materials.)

Waste Generator:

$R=b i c c a$ King

Phone Number:

Location / Origin:

CA 4562

$17 \times 2, \Rightarrow 2$

Waste Category: (check one)

Waste Type: D. NTS

(check one) $\square$ Non-Putrescible

$\square$ Commercial

Industrial

$\square$ Putrescrible

Q FFACO-onsite

$\square$ Asbestos Containing Material

$\square$ FFACO-offsite

Pollution Prevention Category: (check one)

Pollution Prevention Category: (check one)

E Environmental management

Method of Characterization: (check one)

$\lambda$ Clean-Up

Prohibited Waste at all three

NTS landfills:

Additional Prohibited Waste at the Area 9 U10C Landfill:

\section{levels, and Medical wastes (needles, sharps, bloody clothing).}

Sewage Sludge, Animal carcasses, Wet garbage (food waste); and Friable asbestos

\section{REQUIRED: WASTE CONTENTS ALLOWABLE WASTES}

Check all allowable wastes that are contained within this load:

NOTE: Waste disposal at the Area 6 Hydrocarbon Landfill must have come into contact with petroleum hydrocarbons or coolants, such as: gasoline (no benzene, lead); jet fuel; diesel fuel; lubricants and hydraulics; kerosene; asphaltic petroleum hydrocarbon; and ethylene glycol.
Acceptable waste at any NTS landfill:
$\square$ Paper
(ब) Soil
$\square$ Rocks / unaltered geolog
$\square$ Cloth
$\square$ Insulation (non-Asbestosform)
Empty containers
Demolition debris
Cement \& concrete
$\square$ Plastic
Wire
$\square$ Cable
$\square$ cloth
rpet, electronic components, PPE, etc.)
Additional waste accepted at the Area 23 Mercury Landfill:
$\square$ Office Waste
$\square$ Food Waste
$\square$ Asbestos
Friable
Non-Friable (conta
$\square$ Non-friable asbestos
Drained automobiles and military vehicles
$\square$ Light ballasts (contact SWO)
Drained fuel filters (gas \& diesel)
Other
Additional waste accepted at the Area 9 U10c Landfill:
Quantity:
Solid fractions from sand/oil/water
$\square$ Hydrocarbons (contact SWO
$\square$ Deconned Underground and Above Ground Tanks

Animal Carcasses

Additional waste accepted at the Area 6 Hydrocarbon Landfill:
$\square$ Septic sludge
$\square$ Rags
$\square$ Drained fuel filters (gas \& diesel)
$\square$ Sludge from sand/oil/water separators
Crushed non-teme plated oil filters
Plants
$\square$ Soil
REQUIRED: WASTE GENERATOR SIGNATURE

Initials: . (if initialed, no radiological clearance is necessary.)

The above mentioned waste was generated outside of a Controlled Waste Management Area (CWMA) and to the best of my knowledge, does not contain radiological materials.

To the best of my knowledge, the waste described above contains only 1 site. I have verified this through the waste characterization method iden prohibited and allowable waste items. I have contacted Property Manag is approved for disposal in the landfill.

Print Name: Pfoc E DE Lill H

Signature: /s/: Signature on File

Date:

Note: "Food waste, office trash and animal carcasses do not require a ra must have signed removal certification statement with Load Verific
Radiological Survey Release for Waste Disposal RCT Initials

This container/load meets the criteria for no added man-made radioactive material This container/load meets the criteria for Radcon Manual Table 4.2 release limits.

Q This container/load is exempt from survey due to Oracess knowledge and origin.

SIGNATURE: $/ \mathrm{s} /:$ Signature on File DATE: $12 / 48 / 4$ FRM-0646 (08/06) SWO USE ONLY

Load Weight (net from scale or estimate): 2080 a Signature of Certifier: _s/: Signature on File 


\begin{tabular}{|c|c|c|c|c|c|}
\hline SWO USE (Select One) & AREA & 23 & 6 & X $9 / 10 \mathrm{C}$ & LANDFILL \\
\hline
\end{tabular}

REQUIRED: WASTE GERERATOR INFORMATION

(This form is for rolloffs, dump trucks, and other onsite disposal of materials.)

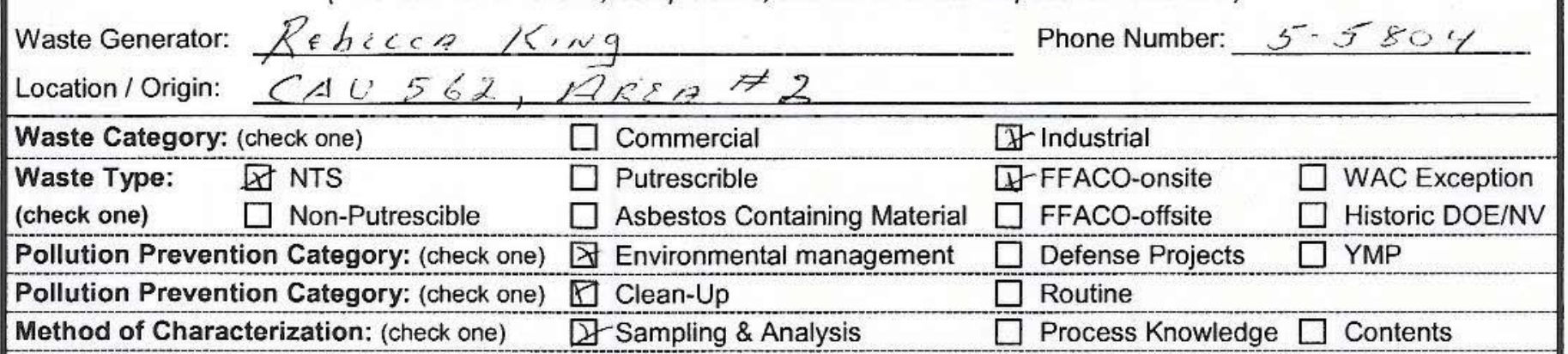

Prohibited Waste at all three Radioactive waste; RCRA waste; Hazardous waste; Free liquids, PCBs above TSCA regulatory NTS landfills:

Additional Prohibited Waste

at the Area 9 U10C Landfill: levels, and Medical wastes (needles, sharps, bloody clothing).

Sewage Sludge, Animal carcasses, Wet garbage (food waste); and Friable asbestos

\section{REQUIRED: WASTE CONTENTS ALLOWABLE WASTES}

Check all allowable wastes that are contained within this load:

NOTE: Waste disposal at the Area 6 Hydrocarbon Landfill must have come into contact with petroleum hydrocarbons or coolants, such as: gasoline (no benzene, lead); jet fuel; diesel fuel; lubricants and hydraulics; kerosene; asphaltic petroleum hydrocarbon; and ethylene glycol.
Acceptable waste at any NTS landfill:
$\square$ Paper
$\square$ Rocks / unaltered geologic materials
Q Soil
$\square$ Rubber (excluding tires)
Empty containers
$\square$ Asphalt $\square$ Metal $\square$ Wood
$\square$ Cloth
$\square$ Insulation (non-Asbestosform)
$\square$ Demolition debris
$\square$ Plastic $\square$ Wire $\square$ Cable
Manufactured items: (swamp coolers, furniture, rugs, carpet, electronic components, PPE, etc.)
Additional waste accepted at the Area 23 Mercury Landfill: $\square$ Office Waste
$\square$ Asbestos
$\square$ Friable
Non-Friable (contact SWO if regulated load)
$\square$ Food Waste
Animal Carcasses
Quantity:

Additional waste accepted at the Area 9 U10c Landfill:
$\square$ Non-friable asbestos
$\square$ Drained automobiles and military vehicles
$\square$ Light ballasts (contact SwO)
$\square$ Drained fuel filters (gas \& diesel)
Solid fractions from sand/oil/water
Hydrocarbons (contact SwO) $\square$ Other
Deconned Underground and Above
Ground Tanks

Additional waste accepted at the Area 6 Hydrocarbon Landfill:
$\square$ Septic sludge
$\square$ Rags
$\square$ Drained fuel filters (gas \& diesel)
$\square$ Sludge from sand/oil/water separators
Crushed non-teme plated oil filters
PCBs below 50 parts per million
Plants Soil REQUIRED: WASTE GENERATOR SIGNATURE

Initials: (if initialed, no radiological clearance is necessary.)

The above mentioned waste was generated outside of a Controlled Waste Management Area (CWMA) and to the best of my knowledge, does not contain radiological materials.

To the best of my knowledge, the waste described above contains only thosı site. I have verified this through the waste characterization method identifie prohibited and allowable waste items. I have contacted Property Manageme is approved for disposal in the landfill.

Print Name:

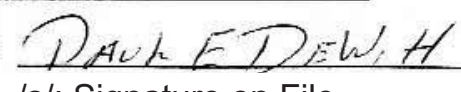

Signature:

$$
\text { /s/: Signature on File }
$$

Note: "Food waste, office trash and animal carcasses do not require a radiól must have signed removal certification statement with Load Verificatio

\section{SWO USE ONLY}

Load Weight (net from scalejor estimate):

\section{Load Weight (net trome}

Radiological Survey Rel and at shie RCT RCT Initials

- This container/load meets the criteria for no added man-made radioactive material This container/load meets the criteria for Radcon Manual Table 4.2 release limits. due container/load is exempt from survey

SIGNATURE: /s/: Signature on File Date: $12 / 48 / 4$ FRM-0646 (08/06) 


\begin{tabular}{llllll}
\hline SWO USE (Select One) & AREA & $\square 23$ & $\square 6$ & $\square 9 / 10 \mathrm{C}$ & LANDFILL
\end{tabular}

For waste characterization, approval, and/or assistance, contact Solid Waste Operation (SWO) at 5-7898. REQUIRED: WASTE GERERATOR INFORMATION

(This form is for rolloffs, dump trucks, and other onsite disposal of materials.)

Waste Generator:
Location / Origin:

Behecen King

CHL $563,4 \& 8$

Waste Category: (check one)

Waste Type: $\forall$ NTS

(check one)

$\square$ Non-Putrescible

Pollution Prevention Category: (check one)

Pollution Prevention Category: (check one)

Method of Characterization: (check one)

$\square$ Commercial
$\square$ Putrescrible
$\square$ Asbestos Containing Material

$\square$ Asbestos Containing Material

Environmental management

$\bigotimes$ Clean-Up

丹 Sampling \& Analysis

Phone Number: $5.50 \%$
NTS landfills:

Additional Prohibited Waste

at the Area 9 U10C Landfill:
Radioactive waste; RCRA waste; Hazardous waste; Free liquids, PCBs above TSCA regulatory levels, and Medical wastes (needles, sharps, bloody clothing).

Sewage Sludge, Animal carcasses, Wet garbage (food waste); and Friable asbestos

\section{REQUIRED: WASTE CONTENTS ALLOWABLE WASTES \\ Check all allowable wastes that are contained within this load:}

NOTE: Waste disposal at the Area 6 Hydrocarbon Landfill must have come into contact with petroleum hydrocarbons or coolants, such as: gasoline (no benzene, lead); jet fuel; diesel fuel; lubricants and hydraulics; kerosene; asphaltic petroleum hydrocarbon; and ethylene glycol.

\begin{tabular}{|c|c|c|c|}
\hline \multicolumn{2}{|c|}{ Acceptable waste at any NTS landfill: } & $\square$ Rocks / unaltered geologic materials & $\square$ Empty containers \\
\hline$\square$ Asphalt & $\square$ Wood & Rubber (excluding tires) & $\square$ Demolition debris \\
\hline Plastic & $\square$ Wire & $\square$ Insulation (non-Asbestosform) & Cement \& concrete \\
\hline \multicolumn{4}{|c|}{ Manufactured items: (swamp coolers, furniture, rugs, carpet, electronic components, PPE, etc.) } \\
\hline \multicolumn{2}{|c|}{ Additional waste accepted at the Area 23 Mercury Landfill: } & 3 Mercury Landfill: & $\square$ Animal Carcasses \\
\hline$\square$ Asbestos & $\square$ Friable & if regulated load) & \\
\hline
\end{tabular}

\section{Additional waste accepted at the Area 9 U10c Landfill:}

Light ballasts (contact SWO)

Hydrocarbons (contact SWO) $\square$

$\square$
Drained automobiles and military vehicles

Drained fuel filters (gas \& diesel)

Other
Solid fractions from sand/oil/water

Deconned Underground and Above Ground Tanks

\section{Additional waste accepted at the Area 6 Hydrocarbon Landfill:}
$\square$ Septic sludge
$\square$ Rags
$\square$ Drained fuel filters (gas \& diesel)
Crushed non-teme plated oil filters
Plants
$\square$ Soil
$\square$ Sludge from sand/oil/water separators
$\square$ PCBs below 50 parts per million REQUIRED: WASTE GENERATOR SIGNATURE

Initials: $\quad$ (if initialed, no radiological clearance is necessary.)

The above mentioned waste was generated outside of a Controlled Waste Management Area (CWMA) and to the best of my knowledge, does not contain radiological materials.

To the best of my knowledge, the waste described above contains only $t$ site. I have verified this through the waste characterization method iden prohibited and allowable waste items. I have contacted Property Managf is approved for disposal in the landfill.

Print Name: Pale DFh! t

Signature: /s/: Signature on File Date:

Note: "Food waste, office trash and animal carcasses do not require a rac must have signed removal certification statement with Load Verifici
Radiological Survey Release for Waste Disposal RCT Initials

This container/load meets the criteria for no added man-made radioactive material This container/load meets the criteria for Radcon Manual Table 4.2 release limits.

D( Th This containerlload is exempt from survey due to SIGNATURE: /s/: Signature on FiledATE: /2/14/4/ FRM-0646 (08/06) SWO USE ONLY

Load Weight (net from scale or estimate): 32,460 Signature of Certifier: . Is/: Signature on File 
,rm

\begin{tabular}{|llllll}
\hline SWO USE (Select One) & AREA & $\square 23$ & $\square 6$ & $\forall 9 / 10 \mathrm{C}$ & LANDFILL
\end{tabular}

For waste characterization, approval, and/or assistance, contact Solid Waste Operation (SWO) at 5-7898. REQUIRED: WASTE GERERATOR INFORMATION

(This form is for rolloffs, dump trucks, and other onsite disposal of materials.)

Waste Generator:

Rebeces Kirig

Location / Origin:

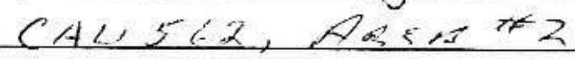

Phone Number: $5+5504$

Waste Category: (check one)

Waste Type: $\bigotimes$ NTS

(check one)

$\square$ Non-Putrescible

$\square$ Commercial

$\square$ Putrescrible

Q Industrial

$\square$ Asbestos Containing Material

7. FFACO-onsite

$\triangle$ Environmental management

Pollution Prevention Category: (check one)

Method of Characterization: (check one)

9 Clean-Up

Prohibited Waste at all three

NTS landfills:

Additional Prohibited Waste

at the Area 9 U10C Landfill:

Radioactive waste; RCRA waste; Hazardous waste; Free liquids, PCBs above TSCA regulatory levels, and Medical wastes (needles, sharps, bloody clothing).

Sewage Sludge, Animal carcasses, Wet garbage (food waste); and Friable asbestos

\section{REQUIRED: WASTE CONTENTS ALLOWABLE WASTES}

Check all allowable wastes that are contained within this load:

NOTE: Waste disposal at the Area 6 Hydrocarbon Landfill must have come into contact with petroleum hydrocarbons or coolants, such as: gasoline (no benzene, lead); jet fuel; diesel fuel; lubricants and hydraulics; kerosene; asphaltic petroleum hydrocarbon; and ethylene glycol.
Acceptable waste at any NTS landfill:
$\square$ Paper
Q 1 Soil
$\square$ Rocks / unaltered geologic materials
$\square$ Rubber (excluding tires)
$\square$ Asphalt
$\square$ Metal
$\square$ Wood
$\square$ Cloth
$\square$ Insulation (non-Asbestosform)
Empty containers
$\square$ Demolition debris
$\square$ Plastic
Cable
Cement \& concrete
Manufactured items: (swamp coolers, furniture, rugs, carpet, electronic components, PPE, etc.)
Additional waste accepted at the Area 23 Mercury Landfill:
$\square$ Office Waste
$\square$ Asbestos
Friable
$\square$ Non-Friable (contact SWO if regulated load)
Quantity:

Additional waste accepted at the Area 9 U10c Landfill:
$\square$ Non-friable asbestos
$\square$ Drained automobiles and military vehicles
Solid fractions from sand/oil/water
$\square$ Light ballasts (contact SWO)
$\square$ Drained fuel filters (gas \& diesel)
Hydrocarbons (contact SWO)
Other
Deconned Underground and Above Ground Tanks

\section{Additional waste accepted at the Area 6 Hydrocarbon Landfill: \\ $\square$ Septic sludge $\square$ Rags $\quad \square$ Drained fuel filters (gas \& diesel) \\ Plants \\ $\square$ Soil \\ $\square$ Sludge from sand/oil/water separators \\ REQUIRED: WASTE GENERATOR SIGNATURE

Crushed non-teme plated oil filters
PCBs below 50 parts per million

Initials: _ (if initialed, no radiological clearance is necessary.)

The above mentioned waste was generated outside of a Controlled Waste Management Area (CWMA) and to the best of my knowledge, does not contain radiological materials.

To the best of my knowledge, the waste described above contains only site. I have verified this through the waste characterization method ide prohibited and allowable waste items. I have contacted Property Mana is approved for disposal in the landfill.

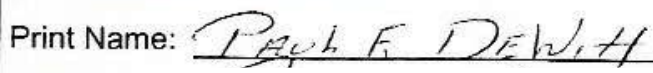

Signature: /s/: Signature on File

Date:

Note: "Food waste, office trash and animal carcasses do not require a $\mathrm{r}$. must have signed removal certification statement with Load Verifi

SWO USE ONLY

Load Weight (net from scale)or estimate):

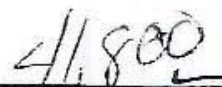

Radiological Survey Release for Waste Disposal RCT Initials

This container/load meets the criteria for no added man-made radioactive material

t- This container/load meets the criteria for

Radcon Manual Table 4.2 release limits.

(2. This container/load is exempt from survey due tofrocess knowledge and origin.

SIGNATURE: _/s/: Signature on FiledATE: $12 / 65 / 4$

FRM-0646 (08/06) 


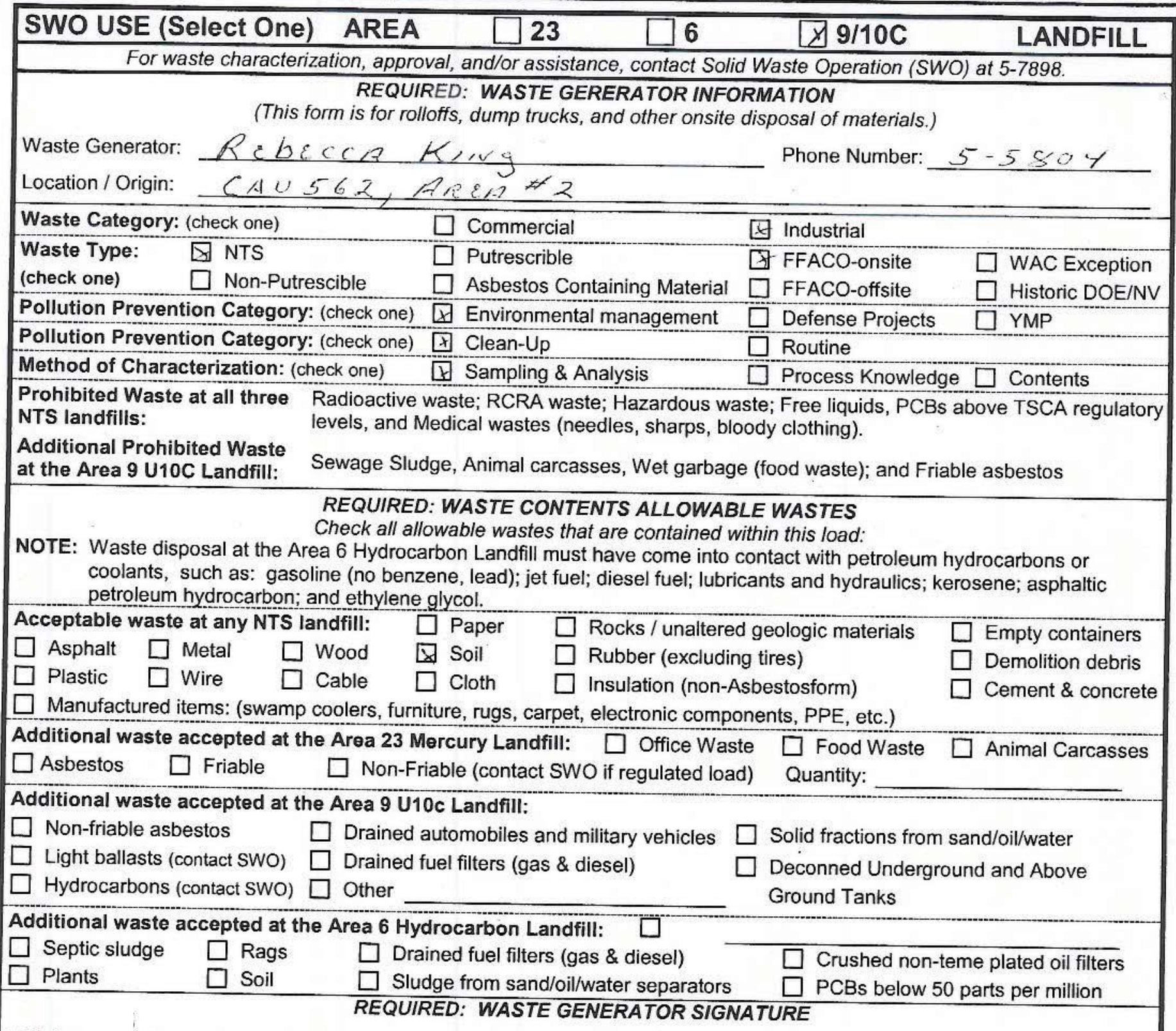

Initials: _ (if initialed, no radiological clearance is necessary.)

The above mentioned waste was generated outside of a Controlled Waste Management Area (CWMA) and to the best of my
knowledge, does not contain radiological materials.

To the best of my knowledge, the waste described above contains only thos site. I have verified this through the waste characterization method identific prohibited and allowable waste items. I have contacted Property Manageme is approved for disposal in the landfill.

Print Name: Pacid F DEL

Signature: /s/: Signature on File Date: $\stackrel{2}{\longrightarrow}$

Note: "Food waste, office trash and animal carcasses do not require a radiol SWO USE ONLY must have
Radiological Survey Release for Waste Disposal RCT Initials

This container/load meets the criteria for no added man-made radioactive material This container/load meets the criteria for Radcon Manual Table 4.2 release limits. This container/load is exempt from survey

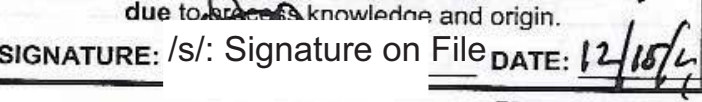
FRM-0646 (08/06)

Load Weight (net from scale or estimate): 34220 Signature of Certifier: /s/: Signature on File 
SWO USE (Select One) AREA

23

6

$\triangle 9 / 10 \mathrm{C}$

LANDFILL

For waste characterization, approval, and/or assistance, contact Solid Waste Operation (SWO) at 5-7898.

REQUIRED: WASTE GERERATOR INFORMATION

(This form is for rolloffs, dump trucks, and other onsite disposal of materials.)

Waste Generator: Rebecca King

Phone Number: 5-5804

Location / Origin: CAU 562 Waste Sites

Waste Category: (check one)

Waste Type:

(check one)

$\square$ NTS

Non-Putrescible

$\square$ Commercial

Putrescrible

$\bigotimes$ Industrial

Pollution Prevention Category: (check one)

Pollution Prevention Category: (check one)

$\square$ Asbestos Containing Material

$\triangle$ FFACO-onsite

$\triangle$ Environmental management

Method of Characterization: (check one)

$\triangle$ Clean-Up

$\square$ FFACO-offsite

1 Defense Projects

$\square$ Routine

Prohibited Waste at all three Radioactive waste; RCRA waste; Hazardous waste; Free liquids, PCBs above TSCA regulatory

NTS landfills:

Additional Prohibited Waste

at the Area 9 U10C Landfill:

levels, and Medical wastes (needles, sharps, bloody clothing).

Sewage Sludge, Animal carcasses, Wet garbage (food waste); and Friable asbestos

\section{REQUIRED: WASTE CONTENTS ALLOWABLE WASTES}

Check all allowable wastes that are contained within this load:

NOTE: Waste disposal at the Area 6 Hydrocarbon Landfill must have come into contact with petroleum hydrocarbons or coolants, such as: gasoline (no benzene, lead); jet fuel; diesel fuel; lubricants and hydraulics; kerosene; asphaltic petroleum hydrocarbon; and ethylene glycol.
Acceptable waste at any NTS landfill:
$\square$ Paper
Rocks / unaltered geologic materials
Soil
$\square$ Rubber (excluding tires)
Empty containers
$\square$ Asphalt
Metal
W Wood
$\square$ Cloth
$\square$ Insulation (non-Asbestosform)
$\square$ Demolition debris
$\square$ Plastic $\square$ Wire
Cable
Cement \& concrete
Manufactured items: (swamp coolers, furniture, rugs, carpet, electronic components, PPE, etc.)
Additional waste accepted at the Area $\mathbf{2 3}$ Mercury Landfill: $\quad \square$ Office Waste
$\square$ Asbestos
$\square$ Friable
Non-Friable (contact SWO if regulated load)
$\square$ Food Waste
Animal Carcasses
Quantity:

Additional waste accepted at the Area 9 U10c Landfill:

Solid fractions from sand/oil/water

Deconned Underground and Above Ground Tanks

Additional waste accepted at the Area 6 Hydrocarbon Landfill:

$\begin{array}{ll}\square \text { Septic sludge } \\ \square \text { Plants } & \square \text { Rags } \\ & \square \text { Soil }\end{array}$

$\square$ Drained fuel filters (gas \& diesel)

$\square$ Sludge from sand/oil/water separators

REQUIRED: WASTE GENERATOR SIGNATURE

\section{Crushed non-teme plated oil filters PCBs below 50 parts per million}

Initials: (if initialed, no radiological clearance is necessary.)

The above mentioned waste was generated outside of a Controlled Waste knowledge, does not contain radiological materials.

To the best of my knowledge, the waste described above contains only the site. I have verified this through the waste characterization method identif prohibited and allowable waste items. I have contacted Property Managen is approved for disposal in the landfill.

Print Name: PAUL E DEW/H

Signature: /s/: Signature on File

Date:

Radiological Survey Release for Waste Disposal RCT Initials

This container/load meets the criteria for no added man-made radioactive material This container/load meets the criteria for Radcon Manual Table 4.2 release limits. This container/load is exempt from survey due to process knowledge and origin SIGNATURE:/S/: Signature on FiledATE: $\frac{1 / 2 / / 2}{B N-0646(10 / 05)}$

Note: "Food waste, office trash and animal carcasses do not require a radiological clearance. Freon-containing appliances must have signed removal certification statement with Load Verification."

\section{SWO USE ONLY}

Load Weight (net from (scale or estimate):

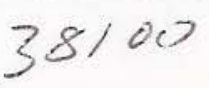




\begin{tabular}{llllll}
\hline SWO USE (Select One) & AREA & $\square 23$ & $\square 6$ & \9/10C & LANDFILL
\end{tabular}

For waste characterization, approval, and/or assistance, contact Solid Waste Operation (SWO) at 5-7898.

REQUIRED: WASTE GERERATOR INFORMATION

(This form is for rolloffs, dump trucks, and other onsite disposal of materials.)

Waste Generator: Rebecca King

Phone Number: $5-5804$

Location / Origin: CAU 562 Waste Sites

Waste Category: (check one)

Waste Type: $\square$ NTS

(check one)

$\square$ Non-Putrescible

$\square$ Commercial

$\triangle$ Industrial

Pollution Prevention Category: (check one) $\triangle$ Environmental management

Pollution Prevention Category: (check one) $\triangle$ Clean-Up

Method of Characterization: (check one) $\triangle$ Sampling \& Analysis

$\triangle$ FFACO-onsite $\square$ WAC Exception

Prohibited Waste at all three

NTS landfills:

Additional Prohibited Waste

at the Area 9 U10C Landfill:

Radioactive waste; RCRA waste; Hazardous waste; Free liquids, PCBs above TSCA regulatory levels, and Medical wastes (needles, sharps, bloody clothing).

Sewage Sludge, Animal carcasses, Wet garbage (food waste); and Friable asbestos

\section{REQUIRED: WASTE CONTENTS ALLOWABLE WASTES}

Check all allowable wastes that are contained within this load:

NOTE: Waste disposal at the Area 6 Hydrocarbon Landfill must have come into contact with petroleum hydrocarbons or coolants, such as: gasoline (no benzene, lead); jet fuel; diesel fuel; lubricants and hydraulics; kerosene; asphaltic petroleum hydrocarbon; and ethylene glycol.
Acceptable waste at any NTS landfill:
$\square$ Paper
$\square$ Rocks / unaltered geologic materials
曰 Soil
$\square$ Rubber (excluding tires)
$\square$ Asphalt $\square$ Metal $\square$ Wood
$\square$ Cloth
$\square$ Insulation (non-Asbestosform)
$\square$ Empty containers
$\square$ Demolition debris
$\square$ Plastic $\square$ Wire $\quad \square$ Cable
Manufactured items: (swamp coolers, furniture, rugs, carpet, electronic components, PPE, etc.)
Additional waste accepted at the Area 23 Mercury Landfill: $\square$ Office Waste $\square$ Food Waste $\square$ Animal Carcasses
$\square$ Asbestos $\quad \square$ Friable $\quad \square$ Non-Friable (contact SWO if regulated load) Quantity:
Additional waste accepted at the Area 9 U10c Landfill:
$\square$ Non-friable asbestos
$\square$ Drained automobiles and military vehicles
Light ballasts (contact SWO)
Hydrocarbons (contact SWO)
Drained fuel filters (gas \& diesel)
Other
Solid fractions from sand/oil/water
Deconned Underground and Above Ground Tanks

\section{Additional waste accepted at the \\ $\square$ Septic sludge \\ $\square$ Rags \\ Soil \\ Plants

$\square$ Soil

\section{Area 6 Hydrocarbon Landfill:}
$\square$ Drained fuel filters (gas \& diesel)
$\square$ Sludge from sand/oil/water separators
REQUIRED: WASTE GENERATOR SIGNATURE
Crushed non-teme plated oil filters PCBs below 50 parts per million

Initials: (if initialed, no radiological clearance is necessary.)

The above mentioned waste was generated outside of a Controlled Waste M knowledge, does not contain radiological materials.

To the best of my knowledge, the waste described above contains only thos site. I have verified this through the waste characterization method identifie prohibited and allowable waste items. I have contacted Property Manageme is approved for disposal in the landfill.

Print Name: PauL E DEW, H

Signature: /s/: Signature on File

Date:

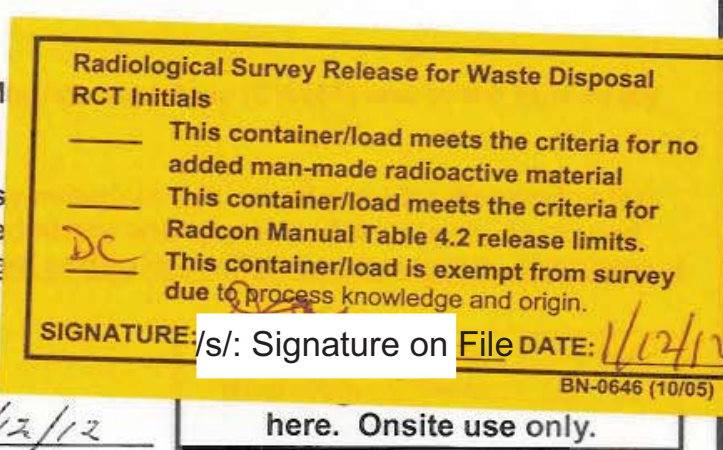

Note: "Food waste, office trash and animal carcasses do not require a radiological clearance. Freon-containing appliances must have signed removal certification statement with Load Verification."

\section{SWO USE ONLY}

Load Weight (net from scale or estimate): 38200 signature of Certifier: /s/: Signature on File 


\begin{tabular}{llllll}
\hline SWO USE (Select One) & AREA & $\square 23$ & $\square 6$ & Q 9/10C & LANDFILL
\end{tabular}

For waste characterization, approval, and/or assistance, contact Solid Waste Operation (SWO) at 5-7898.

\section{REQUIRED: WASTE GERERATOR INFORMATION}

(This form is for rolloffs, dump trucks, and other onsite disposal of materials.)

Waste Generator: Rebecca King

Phone Number: 5-5804

Location / Origin: CAU 562 Waste Sites

Waste Category: (check one)

Waste Type: $\square$ NTS

(check one)

$\square$ Non-Putrescible

$\square$ Commercial
$\square$ Putrescrible
$\square$ Asbestos Containing Material

$\triangle$ Industrial

Pollution Prevention Category: (check one) $\bigotimes$ Environmental management

Pollution Prevention Category: (check one) $\bigotimes$ Clean-Up

Method of Characterization: (check one)

$\triangle$ Sampling \& Analysis

$\bigotimes$ FFACO-onsite

$\square$ FFACO-offsite

$\square$ WAC Exception

Prohibited Waste at all three Radioactive waste; RCRA waste; Hazardous waste; Free liquids, PCBs above TSCA regulatory NTS landfills:

levels, and Medical wastes (needles, sharps, bloody clothing).

Additional Prohibited Waste at the Area 9 U10C Landfill:

Sewage Sludge, Animal carcasses, Wet garbage (food waste); and Friable asbestos

\section{REQUIRED: WASTE CONTENTS ALLOWABLE WASTES}

Check all allowable wastes that are contained within this load:

NOTE: Waste disposal at the Area 6 Hydrocarbon Landfill must have come into contact with petroleum hydrocarbons or coolants, such as: gasoline (no benzene, lead); jet fuel; diesel fuel; lubricants and hydraulics; kerosene; asphaltic petroleum hydrocarbon; and ethylene glycol.
Acceptable waste at any NTS landfill: $\square$ Paper
$\square$ Rocks / unaltered geologic materials
Empty containers
$\square$ Asphalt $\quad \square$ Metal
$\square$ Plastic $\quad \square$ Wood $\quad \square$ Soil
Wire $\quad \square$ Cable $\quad \square$ Cloth
$\square$ Rubber (excluding tires)
$\square$ Insulation (non-Asbestosform)
$\square$ Demolition debris
Manufactured items: (swamp coolers, furniture, rugs, carpet, electronic components, PPE, etc.)
Cement \& concrete
Additional waste accepted at the Area 23 Mercury Landfill: $\quad \square$ Office Waste
$\square$ Food Waste
$\square$ Asbestos
Friable
$\square$ Non-Friable (contact SWO if regulated load)
Quantity:

\section{Additional waste accepted at the Area 9 U10c Landfill:}
$\square$ Non-friable asbestos
$\square$ Drained automobiles and military vehicles
Light ballasts (contact SWO)
$\square$ Drained fuel filters (gas \& diesel)
Hydrocarbons (contact SWO)
Other

Solid fractions from sand/oil/water

Deconned Underground and Above Ground Tanks

\section{Additional waste accepted at the Area 6 Hydrocarbon Landfill:}
$\square$ Septic sludge
$\square$ Rags
$\square$ Drained fuel filters (gas \& diesel)
Crushed non-teme plated oil filters
Plants
Soil
$\square$ Sludge from sand/oil/water separators
REQUIRED: WASTE GENERATOR SIGNATURE

Initials:

(if initialed, no radiological clearance is necessary.)

The above mentioned waste was generated outside of a Controlled Waste Ma knowledge, does not contain radiological materials.

To the best of my knowledge, the waste described above contains only those site. I have verified this through the waste characterization method identified prohibited and allowable waste items. I have contacted Property Managemen is approved for disposal in the landfill.

Print Name:

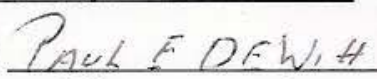

Signature: /s/: Signature on File Date:

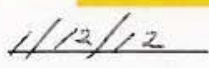

Radiological Survey Release for Waste Disposal RCT Initials

This container/load meets the criteria for no added man-made radioactive material This container/load meets the criteria for Radcon Manual Table 4.2 release limits.

D. This container/load is exempt from survey due to pincess knowledge and origin.

SIGNATURE: /S/: Signature on FileATE: $1 / 12 / 12$ BN-0646(10/05)

Note: "Food waste, office trash and animal carcasses do not require a radiological clearance. Freon-containing appliances must have signed removal certification statement with Load Verification."

SWO USE ONLY

Load Weight (net from \$caleor estimate): 39000 Signature of Certifier:

/s/: Signature on File 


\begin{tabular}{llllll}
\hline SWO USE (Select One) & AREA & $\square 23$ & $\square 6$ & \9/10C & LANDFILL
\end{tabular}

For waste characterization, approval, and/or assistance, contact Solid Waste Operation (SWO) at 5-7898.

REQUIRED: WASTE GERERATOR INFORMATION

(This form is for rolloffs, dump trucks, and other onsite disposal of materials.)

Waste Generator: Rebecca King

Phone Number: 5-5804

Location / Origin: CAU 562 Waste Sites

Waste Category: (check one)

Waste Type: $\square$ NTS

(check one)

$\square$ Non-Putrescible

$\square$ Commercial
$\square$ Putrescrible
$\square$ Asbestos Containing Material

$\triangle$ Industrial

Pollution Prevention Category: (check one) $\triangle$ Environmental management

Pollution Prevention Category: (check one)

Method of Characterization: (check one)

$\triangle$ Clean-Up

$\triangle$ FFACO-onsite

$\square$ WAC Exception

Prohibited Waste at all three

NTS landfills:

$\triangle$ Sampling \& Analysis

$\square$ FFACO-offsite

$\square$ Historic DOE/NV

Additional Prohibited Waste

at the Area 9 U10C Landfill:

levels, and Medical wastes (needles; sharps, bloody clothing).

Sewage Sludge, Animal carcasses, Wet garbage (food waste); and Friable asbestos

\section{REQUIRED: WASTE CONTENTS ALLOWABLE WASTES \\ Check all allowable wastes that are contained within this load:}

NOTE: Waste disposal at the Area 6 Hydrocarbon Landfill must have come into contact with petroleum hydrocarbons or coolants, such as: gasoline (no benzene, lead); jet fuel; diesel fuel; lubricants and hydraulics; kerosene; asphaltic petroleum hydrocarbon; and ethylene glycol.
Acceptable waste at any NTS landfill:
$\square$ Paper
$\square$ Rocks / unaltered geologic materials
国 Soil
$\square$ Rubber (excluding tires)
$\square$ Cloth
$\square$ Insulation (non-Asbestosform)
$\square$ Empty containers
$\square$ Demolition debris
$\square$ Plastic
$\square$ Wire
$\square$ Cable
Manufactured items: (swamp coolers, furniture, rugs, carpet, electronic components, PPE, etc.)
Additional waste accepted at the Area 23 Mercury Landfill: $\square$ Office Waste $\square$ Food Waste $\square$ Animal Carcasses
$\square$ Asbestos
Friable
$\square$ Non-Friable (contact SWO if regulated load)
Quantity:

\section{Additional waste accepted at the Area 9 U10c Landfill:}

$\begin{array}{ll}\square \text { Non-friable asbestos } & \square \text { Drained automobiles and military vehicles } \\ \square \text { Light ballasts (contact SWO) } & \square \text { Drained fuel filters (gas \& diesel) } \\ \square \text { Hydrocarbons (contact SWO) } & \square \text { Other }\end{array}$

Solid fractions from sand/oil/water

$\square$ Deconned Underground and Above Ground Tanks
Additional waste accepted at the Area 6 Hydrocarbon Landfill:
$\square$ Septic sludge
$\square$ Rags
$\square$ Drained fuel filters (gas \& diesel)
Plants
Soil
$\square$ Sludge from sand/oil/water separators
$\square$ Crushed non-teme plated oil filters REQUIRED: WASTE GENERATOR SIGNATURE

Initials: (if initialed, no radiological clearance is necessary.)

The above mentioned waste was generated outside of a Controlled Wast knowledge, does not contain radiological materials.

To the best of my knowledge, the waste described above contains only th site. I have verified this through the waste characterization method ident prohibited and allowable waste items. I have contacted Property Manage is approved for disposal in the landfill.

Print Name:

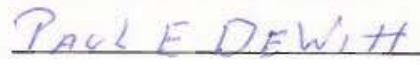

Signature: /s/: Signature on File

Date:

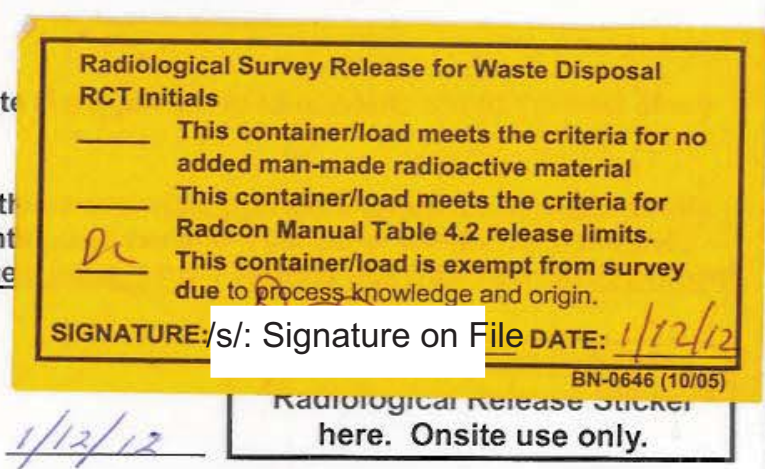

Note: "Food waste, office trash and animal carcasses do not require a radiological clearance. Freon-containing appliances must have signed removal certification statement with Load Verification."

SWO USE ONLY

Load Weight (net from (scale or estimate): 27000 signature of Certifier: _s/: Signature on File 


\begin{tabular}{llllll}
\hline SWO USE (Select One) & AREA & $\square 23$ & $\square 6$ & \9/10C & LANDFILL
\end{tabular}

For waste characterization, approval, and/or assistance, contact Solid Waste Operation (SWO) at 5-7898.

REQUIRED: WASTE GERERATOR INFORMATION

(This form is for rolloffs, dump trucks, and other onsite disposal of materials.)

Waste Generator: Rebecca King Phone Number: 5-5804

Location / Origin: CAU 562 Waste Sites

Waste Category: (check one)

Waste Type: $\square$ NTS

(check one)

$\square$ Non-Putrescible

$\square$ Commercial
$\square$ Putrescrible
$\square$ Asbestos Containing Material

Pollution Prevention Category: (check one) $\bigotimes$ Environmental management

Pollution Prevention Category: (check one) $\triangle$ Clean-Up

Method of Characterization: (check one)

$\triangle$ Sampling \& Analysis

$\triangle$ Industrial

$\triangle$ FFACO-onsite

$\square$ FFACO-offsite

$\square$ WAC Exception

Prohibited Waste at all three

NTS landfills:

$\square$ Defense Projects

$\square$ Historic DOE/NV

Additional Prohibited Waste at the Area 9 U10C Landfill:

Radioactive waste; RCRA waste; Hazardous waste; Free liquids, PCBs above TSCA regulatory levels, and Medical wastes (needles, sharps, bloody clothing).

Sewage Sludge, Animal carcasses, Wet garbage (food waste); and Friable asbestos

\section{REQUIRED: WASTE CONTENTS ALLOWABLE WASTES}

Check all allowable wastes that are contained within this load:

NOTE: Waste disposal at the Area 6 Hydrocarbon Landfill must have come into contact with petroleum hydrocarbons or coolants, such as: gasoline (no benzene, lead); jet fuel; diesel fuel; lubricants and hydraulics; kerosene; asphaltic petroleum hydrocarbon; and ethylene glycol.
Acceptable waste at any NTS landfill:
$\square$ Paper
$\square$ Rocks / unaltered geologic materials
$\square$ Asphalt $\square$ Metal $\square$ Wood
\$ Soil
$\square$ Rubber (excluding tires)
1 Plastic
Cable
Cloth
$\square$ Insulation (non-Asbestosform)
Manufactured items: (swamp coolers, furniture, rugs, carpet, electronic components, PPE, etc.)
Additional waste accepted at the Area 23 Mercury Landfill: $\quad \square$ Office Waste
Food Waste
$\square$ Asbestos
$\square$ Friable
$\square$ Non-Friable (contact
Additional waste accep
$\square$ Non-friable asbestos
Light ballasts (contact Swo)
$\square$ Drained automobiles and military vehicles
Quantity:
$\square$ Hydrocarbons (contact SWO) $\square$ Other
Solid fractions from sand/oil/water
Deconned Underground and Above Ground Tanks

$\square$ Empty containers

$\square$ Demolition debris

$\boxplus$ Cement \& concrete

Animal Carcasses

Additional waste accepted at the Area 6 Hydrocarbon Landfill:
$\square$ Septic sludge
$\square$ Rags
$\square$ Drained fuel filters (gas \& diesel)
Plants
Soil
$\square$ Sludge from sand/oil/water separators

Initials: (if initialed, no radiological clearance is necessary.)

The above mentioned waste was generated outside of a Controlled Waste knowledge, does not contain radiological materials.

To the best of my knowledge, the waste described above contains only th site. I have verified this through the waste characterization method identi prohibited and allowable waste items. I have contacted Property Manage is approved for disposal in the landfill.

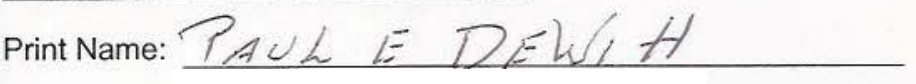

Signature: /s/: Signature on File Date:

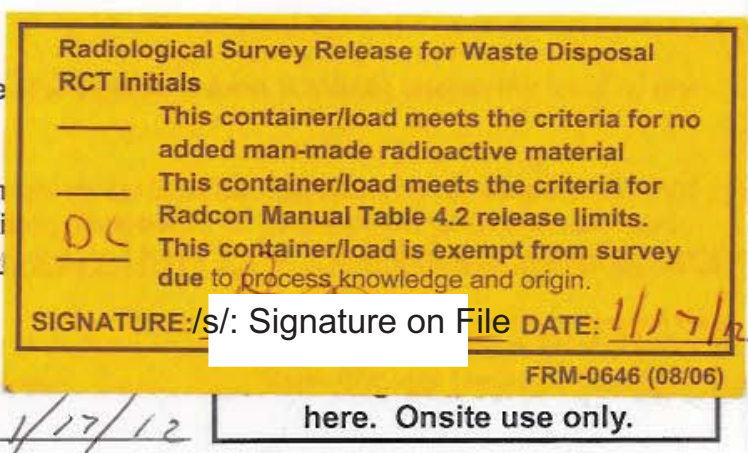

Note: "Food waste, office trash and animal carcasses do not require a radiological clearance. Freon-containing appliances must have signed removal certification statement with Load Verification."

\section{SWO USE ONLY}

Load Weight (net from scale or estimate): $36800 \mathrm{~J}$ Signature of Certifier: /s/: Signature on File 


\section{\begin{tabular}{llllll}
\hline SWO USE (Select One) & AREA & $\square 23$ & $\square 6$ & A 9/10C & LANDFILL
\end{tabular}}

For waste characterization, approval, and/or assistance, contact Solid Waste Operation (SWO) at 5-7898.

\section{REQUIRED: WASTE GERERATOR INFORMATION}

(This form is for rolloffs, dump trucks, and other onsite disposal of materials.)

Waste Generator: Rebecca King

Phone Number: $5-5804$

Location / Origin: CAU 562 Waste Sites

Waste Category: (check one)

Waste Type: $\square$ NTS

(check one)

Non-Putrescible

$\square$ Commercial
$\square$ Putrescrible
$\square$ Asbestos Containing Material

$\triangle$ Industrial

Pollution Prevention Category: (check one) $\bigotimes$ Environmental management

Pollution Prevention Category: (check one)

Method of Characterization: (check one)

$\triangle$ Clean-Up

$\triangle$ FFACO-onsite

WAC Exception

Prohibited Waste at all three

NTS landfills:

$\triangle$ Sampling \& Analysis

$\square$ FFACO-offsite

$\square$ Historic DOE/NV

Additional Prohibited Waste

at the Area 9 U10C Landfill:

Radioactive waste; RCRA waste; Hazardous waste; Free liquids, PCBs above TSCA regulatory levels, and Medical wastes (needles, sharps, bloody clothing).

Sewage Sludge, Animal carcasses, Wet garbage (food waste); and Friable asbestos

\section{REQUIRED: WASTE CONTENTS ALLOWABLE WASTES}

Check all allowable wastes that are contained within this load:

NOTE: Waste disposal at the Area 6 Hydrocarbon Landfill must have come into contact with petroleum hydrocarbons or coolants, such as: gasoline (no benzene, lead); jet fuel; diesel fuel; lubricants and hydraulics; kerosene; asphaltic petroleum hydrocarbon; and ethylene glycol.
Acceptable waste at any NTS landfill:
$\square$ Paper
$\square$ Rocks / unaltered geologic materials
Empty containers
$\square$ Asphalt $\square$ Metal $\square$ Wood
$\$$ Soil
$\square$ Rubber (excluding tires)
$\square$ Demolition debris
$\square$ Plastic
Cable
$\square$ Cloth
$\square$ Insulation (non-Asbestosform)
\$ Cement \& concrete
Manufactured items: (swamp coolers, furniture, rugs, carpet, electronic components, PPE, etc.)
Additional was
$\square$ Asbestos
Area 23 Mercury Landfill:
Office Waste
$\square$ Food Waste
Animal Carcasses

Additional waste accepted at the Area 9 U10c Landfill:
$\square$ Non-friable asbestos
$\square$ Drained automobiles and military vehicles
$\square$ Light ballasts (contact SWO)
$\square$ Drained fuel filters (gas \& diesel)
Hydrocarbons (contact SWO)
Other

Solid fractions from sand/oil/water

Deconned Underground and Above

Ground Tanks

\section{Additional waste accepted at the Area 6 Hydrocarbon Landfill:}
$\square$ Septic sludge
$\square$ Rags
$\square$ Drained fuel filters (gas \& diesel)
Crushed non-teme plated oil filters
Plants
Soil
$\square$ Sludge from sand/oil/water separators
$\square$ PCBs below 50 parts per million
REQUIRED: WASTE GENERATOR SIGNATURE

Initials:

(if initialed, no radiological clearance is necessary.)

The above mentioned waste was generated outside of a Controlled Waste Manag knowledge, does not contain radiological materials.

To the best of my knowledge, the waste described above contains only those ma site. I have verified this through the waste characterization method identified ab prohibited and allowable waste items. I have contacted Property Management ar is approved for disposal in the landfill.

Print Name: PAUL $=D E h / H$

Signature: /s/: Signature on File

Date:

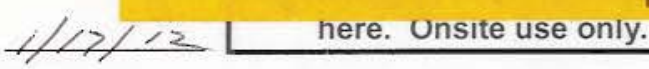

Radiological Survey Release for Waste Disposal RCT Initials

This container/load meets the criteria for no added man-made radioactive material This container/load meets the criteria for Radcon Manual Table 4.2 release limits.

DC This container/load is exempt from survey due trumnnoce knnuilarige and origin. SIGNATURE:/S/: Signature on File DATE: $1 / 7 / 12$ FRM-0646 (08/06)

Note: "Food waste, office trash and animal carcasses do not require a radiological clearance. Freon-containing appliances must have signed removal certification statement with Load Verification."

SWO USE ONLY

Load Weight (net from scale or estimate): $348 \mathrm{k} / 0 \mathrm{~J}$ Signature of Certifier: _s/: Signature on File 
.STec

Form

\begin{tabular}{llllll}
\hline SWO USE (Select One) & AREA & $\square 23$ & $\square 6$ & A 9/10C & LANDFILL
\end{tabular}

For waste characterization, approval, and/or assistance, contact Solid Waste Operation (SWO) at 5-7898.

REQUIRED: WASTE GERERATOR INFORMATION

(This form is for rolloffs, dump trucks, and other onsite disposal of materials.)

Waste Generator: Rebecca King

Phone Number: 5-5804

Location / Origin: Area 23, CAU 562 CAS 23-60-01, \& 23-9906

Waste Category: (check one)

Waste Type: $\square$ NTS

$\square$ Commercial
$\square$ Putrescrible
$\square$ Asbestos Containing Material

\ Industrial

(check one) $\square$ Non-Putrescible $\square$ Asbestos Containing Material

Pollution Prevention Category: (check one) \ Environmental management

Pollution Prevention Category: (check one) $\triangle$ Clean-Up

$\triangle$ FFACO-onsite

Method of Characterization: (check one) $\bigotimes$ Sampling \& Analysis

$\square$ FFACO-offsite

$\square$ WAC Exception

Prohibited Waste at all three Radioactive waste; RCRA waste; Hazardous waste; Free liquids, PCBs above TSCA regulatory NTS landfills:

levels, and Medical wastes (needles, sharps, bloody clothing).

Additional Prohibited Waste

at the Area 9 U10C Landfill:

Sewage Sludge, Animal carcasses, Wet garbage (food waste); and Friable asbestos

\section{REQUIRED: WASTE CONTENTS ALLOWABLE WASTES}

Check all allowable wastes that are contained within this load:

NOTE: Waste disposal at the Area 6 Hydrocarbon Landfill must have come into contact with petroleum hydrocarbons or coolants, such as: gasoline (no benzene, lead); jet fuel; diesel fuel; lubricants and hydraulics; kerosene; asphaltic petroleum hydrocarbon; and ethylene glycol.
Acceptable waste at any NTS landfill:
$\square$ Paper
$\bigotimes$ Rocks / unaltered geologic materials
Empty containers
$\square$ Asphalt 叉 Metal $\square$ Wood
$\bigotimes$ Soil
$\square$ Rubber (excluding tires)
$\square$ Plastic
$\bigotimes$ Cable
$\square$ Insulation (non-Asbestosform)
$\bigotimes$ Demolition debris
\. Cement \& concrete
Manufactured items: (swamp coolers, furniture, rugs, carpet, electronic components, PPE, etc.)
Additional waste accepted at the Area 23 Mercury Landfill: $\quad \square$ Office Waste
$\square$ Asbestos
Friable
$\square$ Non-Friable (contact SWO if regulated load)
$\square$ Food Waste
Animal Carcasses
Quantity:

Additional waste accepted at the Area 9 U10c Landfill:

Solid fractions from sand/oil/water

$\square$ Deconned Underground and Above Ground Tanks

\section{Additional waste accepted at the Area 6 Hydrocarbon Landfill: \\ $\square$ Septic sludge $\quad \square$ Rags $\quad \square$ Drained fuel filters (gas \& diesel) \\ Plants $\quad \square$ Soil \\ $\square$ Sludge from sand/oil/water separators \\ REQUIRED: WASTE GENERATOR SIGNATURE \\ Crushed non-teme plated oil filters PCBs below 50 parts per million}

Initials: (if initialed, no radiological clearance is necessary.)

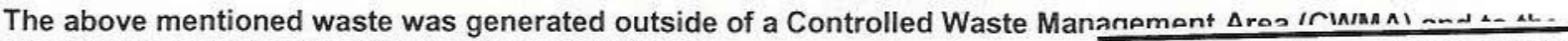

knowledge, does not contain radiological materials.

To the best of my knowledge, the waste described above contains only those site. I have verified this through the waste characterization method identified prohibited and allowable waste items. I have contacted Property Management is approved for disposal in the dandfill.

Print Name:

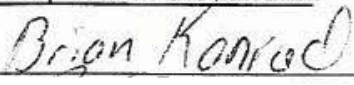

Signature: /s/: Signature on File Radiological Survey Release for Waste Disposal RCT Initials

This container/load meets the criteria for no added man-made radioactive material This container/load meets the criteria for Radcon Manual Table 4.2 release limits.

DC This container/load is exempt from survey due to rocess knowledge and origin.

Date: $1 / 19 / 12$ SIGNATURE:/S/: Signature on File DATE: $1 / 1$ \& $/ \mathrm{l}$

FRM-0646 (08/06)

Note: "Food waste, office trash and animal carcasses do not require a radiological ciearance. r reon-containing appliances must have signed removal certification statement with Load Verification."

SWO USE ONLY

Load Weight (net from scale or estimate): 19300

Signature of Certifier: /s/: Signature on File 


\begin{tabular}{|llllll}
\hline SWO USE (Select One) & AREA & $\square 23$ & $\square 6$ & $\square 9 / 10 \mathrm{C}$ & LANDFILL
\end{tabular}

For waste characterization, approval, and/or assistance, contact Solid Waste Operation (SWO) at 5-7898.

\section{REQUIRED: WASTE GERERATOR INFORMATION}

(This form is for rolloffs, dump trucks, and other onsite disposal of materials.)

Waste Generator: Rebecca hing

Location / Origin:

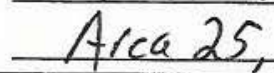

CAU 562

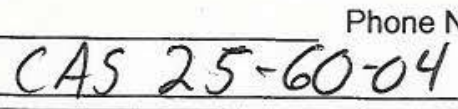

Waste Category: (check one)

Waste Type: $\square$ NTS

(check one)

$\square$ Non-Putrescible

$\square$ Commercial

区 Industrial

$\triangle$ FFACO-onsite

$\square$ Asbestos Containing Material

$\square$ FFACO-offsite

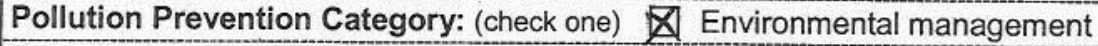

Pollution Prevention Category: (check one) X Clean-Up

Method of Characterization: (check one) \ Sampling \& Analysis

$\square$ Defense Projects

Exception

Prohibited Waste at all three

NTS landfills:

Additional Prohibited Waste

at the Area 9 U10C Landfill:

Radioactive waste; RCRA waste; Hazardous waste; Free liquids, PCBs above TSCA regulatory levels, and Medical wastes (needles, sharps, bloody clothing).

Sewage Sludge, Animal carcasses, Wet garbage (food waste); and Friable asbestos

\section{REQUIRED: WASTE CONTENTS ALLOWABLE WASTES}

Check all allowable wastes that are contained within this load:

NOTE: Waste disposal at the Area 6 Hydrocarbon Landfill must have come into contact with petroleum hydrocarbons or coolants, such as: gasoline (no benzene, lead); jet fuel; diesel fuel; lubricants and hydraulics; kerosene; asphaltic petroleum hydrocarbon; and ethylene glycol.
Acceptable waste at any NTS landfill:
$\square$ Paper
Rocks / unaltered geologic materials
$\square$ Asphalt
口Xetal
W Wood
ॠ. Soil
$\square$ Rubber (excluding tires)
$\square$ Cloth
$\square$ Insulation (non-Asbestosform)
Empty containers
区 Demolition debris
Plastic
Cable
प्⿱ Cement \& concrete

$\square$ Cloth

carpet, electronic components, PPE, etc.)
Additional waste accepted at the Area 23 Mercury Landfill:
$\square$ Asbestos
Friable
Non-Friable (contact SWO if regulated load)
Additional waste accepted at the Area 9 U10c Landfill:
$\square$ Non-friable asbestos
$\square$ Drained automobiles and military vehicles
$\square$ Light ballasts (contact SWO)
$\square$ Drained fuel filters (gas \& diesel)
Hydrocarbons (contact SWO)
Other

$\square$ Food Waste

Animal Carcasses

Quantity:

\begin{tabular}{|c|c|c|c|}
\hline Additional waste & cepted at & ea 6 Hydrocarbon Landfill: & \\
\hline$\square$ Septic sludge & $\square$ Rags & $\square$ Drained fuel filters (gas \& diesel) & $\square$ Crushed non-teme plated oil filters \\
\hline$\square$ Plants & $\square$ Soil & $\square$ Sludge from sand/oil/water separators & X PCBs below 50 parts per million \\
\hline
\end{tabular}

Initials: (if initialed, no radiological clearance is necessary.)

The above mentioned waste was generated outside of a Controlled Waste Manageme knowledge, does not contain radiological materials.

To the best of my knowledge, the waste described above contains only those materia site. I have verified this through the waste characterization method identified above : prohibited and allowable waste items. I have contacted Property Management and hi is approved for disposal in the landfill.

Print Name:<smiles>C1CCCCC1</smiles><smiles>CCOC1(C)CCCCC1</smiles>

Signature: /s/: Signature on File Date: $1 / 2 i / 12$ Solid fractions from sand/oil/water Deconned Underground and Above Ground Tanks

Note: "Food waste, office trash and animal carcasses do not require a radiological clearance. Freon-containing appliances must have signed removal certification statement with Load Verification."

SWO USE ONLY

Load Weight (net from scale or estimate):

Radiological Survey Release for Waste Disposal RCT Initials This container/load meets the criteria for no added man-made radioactive material This container/load meets the criteria for Radcon Manual Table 4.2 release limits. This container/load is exempt from survey due to pracess knowledae and origin SIGNATURE:/S/: Signature on File DATE: $1 / 241$ FRM-0646 (08/06) 


\begin{tabular}{|llllll}
\hline SWO USE (Select One) & AREA & $\square 23$ & $\square 6$ & $\backslash$ 9/10C & LANDFILL
\end{tabular}

For waste characterization, approval, and/or assistance, contact Solid Waste Operation (SWO) at 5-7898.

REQUIRED: WASTE GERERATOR INFORMATION

(This form is for rolloffs, dump trucks, and other onsite disposal of materials.)

Waste Generator: Rebecca King

Location / Origin:

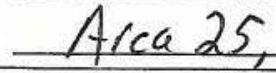

CAU 562

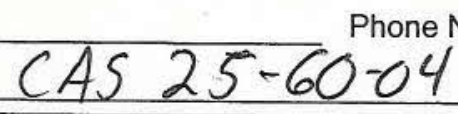

Waste Category: (check one)

Waste Type:

(check one)

$\square$ NTS

$\square$ Commercial

\Industrial

$\square$ Putrescrible

\ FFACO-onsite

$\square$ Asbestos Containing Material

$\square$ FFACO-offsite

Exception

Pollution Prevention Category: (check one) E Environmental management

Pollution Prevention Category: (check one) $X$ Clean-Up

Method of Characterization: (check one) X Sampling \& Analysis

$\square$ Defense Projects

$\square$ YMP

$\square$ Process Knowledge $\square$ Contents

Prohibited Waste at all three Radioactive waste; RCRA waste; Hazardous waste; Free liquids, PCBs above TSCA regulatory NTS landfills:

Additional Prohibited Waste

at the Area 9 U10C Landfill:

levels, and Medical wastes (needles, sharps, bloody clothing).

Sewage Sludge, Animal carcasses, Wet garbage (food waste); and Friable asbestos

\section{REQUIRED: WASTE CONTENTS ALLOWABLE WASTES}

Check all allowable wastes that are contained within this load:

NOTE: Waste disposal at the Area 6 Hydrocarbon Landfill must have come into contact with petroleum hydrocarbons or coolants, such as: gasoline (no benzene, lead); jet fuel; diesel fuel; lubricants and hydraulics; kerosene; asphaltic petroleum hydrocarbon; and ethylene glycol.
Acceptable waste at any NTS landfill:
$\square$ Paper
$\square$ Rocks / unaltered geologic materials
$\square$ Rubber (excluding tires)
[] Soil
$\square$ Insulation (non-Asbestosform)
$\square$ Empty containers
区 Demolition debris
$\square$ Plastic
$\square$ Wire
Wood
$\square$ Cloth

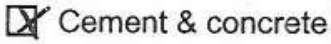

Manufactured items: (swamp coolers, furniture, rugs, carpet, electronic components, PPE, etc.)

Additional waste accepted at the Area 23 Mercury Landfill: $\square$ Office Waste $\square$ Food Waste. $\square$ Animal Carcasses

$\square$ Asbestos

$\square$ Friable

$\square$ Non-Friable (contact SWO if regulated load)

Quantity:

Additional waste accepted at the Area 9 U10c Landfill:
$\square$ Non-friable asbestos
$\square$ Drained automobiles and military vehicles
$\square$ Light ballasts (contact SWO)
Drained fuel filters (gas \& diesel)
Other
$\square$ Hydrocarbons (contact SWO)

Solid fractions from sand/oil/water

Additional waste accepted at the Area 6 Hydrocarbon Landfill:
$\square$ Septic sludge
$\square$ Rags
$\square$ Drained fuel filters (gas \& diesel)
$\square$ Sludge from sand/oil/water separators

\section{REQUIRED: WASTE GENERATOR SIGNATURE}

Deconned Underground and Above Ground Tanks

Initials: (if initialed, no radiological clearance is necessary.)

The above mentioned waste was generated outside of a Controlled Waste Management Area (CWMA) and to the best of my knowledge, does not contain radiological materials.

To the best of my knowledge, the waste described above contains only those $\mathrm{m}$ site. I have verified this through the waste characterization method identified at prohibited and allowable waste items. I have contacted Property Management a is approved for disposal in the landfill.

Print Name:

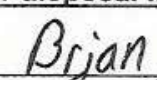

haniad

Signature: /s/: Signature on File

Date: $1 / 2 u / 1$.

Note: "Food waste, office trash and animal carcasses do not require a radiologic must have signed removal certification statement with Load Verification."

Radiological Survey Release for Waste Disposal RCT Initials

This container/load meets the criteria for no added man-made radioactive material This container/load meets the criteria for Radcon Manual Table 4.2 release limits. This container/load is exempt from survey due to prodess-knowlenina and origin. RE: SWO USE ONLY

Load Weight (net from scale or estimate): 


\begin{tabular}{|llllll}
\hline SWO USE (Select One) & AREA & $\square 23$ & $\square 6$ & Q 9/10C & LANDFILL
\end{tabular}

For waste characterization, approval, and/or assistance, contact Solid Waste Operation (SWO) at 5-7898.

REQUIRED: WASTE GERERATOR INFORMATION

(This form is for rolloffs, dump trucks, and other onsite disposal of materials.)

Waste Generator: Rebecca King

Phone Number: 5-5804

Location / Origin: Area 23, CAU 562 CAS 23-60-01, 23-9906 / / / / / / / 2

Waste Category: (check one)

Waste Type: $\quad \square$ NTS

$\square$ Commercial

$\triangle$ Industrial

(check one)

$\square$ Putrescrible

$\triangle$ FFACO-onsite

$\square$ Asbestos Containing Material

$\square$ FFACO-offsite

Pollution Prevention Category: (check one) $\bigotimes$ Environmental management

Pollution Prevention Category: (check one) $\bigotimes$ Clean-Up

$\square$ Defense Projects

Method of Characterization: (check one)

$\triangle$ Sampling \& Analysis

$\square$ Routine

Prohibited Waste at all three

NTS landfills:

Radioactive waste; RCRA waste; Hazardous waste; Free liquids, PCBs above TSCA regulatory levels, and Medical wastes (needles, sharps, bloody clothing).

Additional Prohibited Waste
at the Area 9 U10C Landfill:

\section{REQUIRED: WASTE CONTENTS ALLOWABLE WASTES}

Check all allowable wastes that are contained within this load:

NOTE: Waste disposal at the Area 6 Hydrocarbon Landfill must have come into contact with petroleum hydrocarbons or coolants, such as: gasoline (no benzene, lead); jet fuel; diesel fuel; lubricants and hydraulics; kerosene; asphaltic petroleum hydrocarbon; and ethylene glycol.
Acceptable waste at any NTS landfill:
$\square$ Paper
$\triangle$ Rocks / unaltered geologic materials
$\square$ Empty containers
$\square$ Asphalt
Q Metal
$\square$ Wood
$\bigotimes$ Soil
$\square$ Rubber (excluding tires)
$\bigotimes$ Demolition debris
$\square$ Plastic
$\triangle$ Cable
$\square$ Cloth
$\square$ Insulation (non-Asbestosform)
区 Cement \& concrete
Manufactured items: (swamp coolers, furniture, rugs, carpet, electronic components, PPE, etc.)
Additional waste accepted at the Area 23 Mercury Landfill:
$\square$ Office Waste
$\square$ Food Waste
Animal Carcasses
$\square$ Asbestos
Friable
$\square$ Non-Friable (contact SWO if regulated load)
Quantity:

Additional waste accepted at the Area 9 U10c Landfill:
$\square$ Non-friable asbestos
Drained automobiles and military vehicles
Light ballasts (contact SWO)
Drained fuel filters (gas \& diesel)
$\triangle$ Hydrocarbons (contact SWO)
Other

Solid fractions from sand/oil/water

$\square$ Deconned Underground and Above Ground Tanks

Additional waste accepted at the Area 6 Hydrocarbon Landfill:
$\square$ Septic sludge
$\square$ Rags
$\square$ Drained fuel filters (gas \& diesel)
Crushed non-teme plated oil filters
Plants
Soil
$\square$ Sludge from sand/oil/water separators
$\square$ PCBs below 50 parts per million
REQUIRED: WASTE GENERATOR SIGNATURE

Initials: (if initialed, no radiological clearance is necessary.)

The above mentioned waste was generated outside of a Controlled Waste Manacement Area (CWMA) and to the best of my knowledge, does not contain radiological materials.

To the best of my knowledge, the waste described above contains only tho: site. I have verified this through the waste characterization method identifi prohibited and allowable waste items. I have contacted Property Managem is approved for disposal in the landfill.

Print Name:

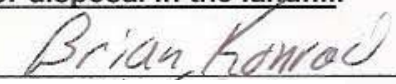

Signature: /s/: Signature on File

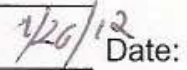

Radiological Survey Release for Waste Disposal RCT Initiais

- This container/load meets the criteria for no added man-made radioactive material This container/load meets the criteria fo Radcon Manual Table 4.2 release limits.

DCTV This container/load is exempt from survey due to podessknowledae and origin SIGNATURE:/S/: Signature on File DATE: I// \& $a$ FRM-0646 (08/06)

Note: "Food waste, office trash and animal carcasses do not require a radiorvy must have signed removal certification statement with Load Verification."

\section{SWO USE ONLY}

Load Weight (net from scale or estimate)

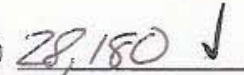

Signature of Certifier:

/s/: Signature on File 


\begin{tabular}{llllll}
\hline SWO USE (Select One) & AREA & $\square 23$ & $\square 6$ & D9/10C & LANDFILL
\end{tabular}

For waste characterization, approval, and/or assistance, contact Solid Waste Operation (SWO) at 5-7898.

\section{REQUIRED: WASTE GERERATOR INFORMATION}

(This form is for rolloffs, dump trucks, and other onsite disposal of materials.)

Waste Generator: Rebecca King Phone Number: $5-5804$

Location / Origin: Area \#25, CAU 562 CAS 25-60-04

Waste Category: (check one)

$\square$ Commercial

$\bigotimes$ Industrial

Waste Type: $\square$ NTS

$\square$ Putrescrible

$\triangle$ FFACO-onsite

$\square$ WAC Exception

(check one)

Non-Putrescible

$\square$ Asbestos Containing Material

Pollution Prevention Category: (check one) $\triangle$ Environmental management

Pollution Prevention Category: (check one)

$\triangle$ Clean-Up

$\square$ FFACO-offsite

$\square$ Historic DOE/NV

Method of Characterization: (check one)

$\triangle$ Sampling \& Analysis

Defense Projects

YMP

Prohibited Waste at all three Radioactive waste; RCRA waste; Hazardous waste; Free liquids, PCBs above TSCA regulatory NTS landfills:

Additional Prohibited Waste

at the Area 9 U10C Landfill: levels, and Medical wastes (needles, sharps, bloody clothing).

Sewage Sludge, Animal carcasses, Wet garbage (food waste); and Friable asbestos

REQUIRED: WASTE CONTENTS ALLOWABLE WASTES

Check all allowable wastes that are contained within this load:

NOTE: Waste disposal at the Area 6 Hydrocarbon Landfill must have come into contact with petroleum hydrocarbons or coolants, such as: gasoline (no benzene, lead); jet fuel; diesel fuel; lubricants and hydraulics; kerosene; asphaltic petroleum hydrocarbon; and ethylene glycol.
Acceptable waste at any NTS landfill:
$\square$ Paper
$\triangle$ Rocks / unaltered geologic materials
$\square$ Asphalt
$\bigotimes$ Metal
$\bigotimes$ Wood
$\bigotimes$ Soil
$\square$ Rubber (excluding tires)
Plastic $\square$ Wire
Cable
$\square$ Cloth
$\square$ Insulation (non-Asbestosform)

$\square$ Empty containers

$\bigotimes$ Demolition debris

Manufactured items: (swamp coolers, furniture, rugs, carpet, electronic components, PPE, etc.)
Additional was
Friable
Area 23 Mercury Landfil

\section{Office Waste}
Food Waste
Quantity:
Animal Carcasses

$\bigotimes$ Cement \& concrete

\section{Additional waste accepted at the Area 9 U10c Landfill:}

$\begin{array}{ll}\square \text { Non-friable asbestos } & \square \text { Drained automobiles and military vehicles } \\ \square \text { Light ballasts (contact SwO) } & \square \text { Drained fuel filters (gas \& diesel) } \\ \square \text { Hydrocarbons (contact SWO) } & \square \text { Other }\end{array}$

Additional waste accepted at the Area 6 Hydrocarbon Landfill:
$\square$ Septic sludge
$\square$ Rags
$\square$ Drained fuel filters (gas \& diesel)
Plants
Soil
$\square$ Sludge from sand/oil/water separators
REQUIRED: WASTE GENERATOR SIGNATURE

Solid fractions from sand/oil/water

Deconned Underground and Above Ground Tanks

Initials: (if initialed, no radiological clearance is necessary.)

The above mentioned waste was generated outside of a Controlled Waste Managem knowledge, does not contain radiological materials.

To the best of my knowledge, the waste described above contains only those mate site. I have verified this through the waste characterization method identified abov prohibited and allowable waste items. I have contacted Property Management and is approved for disposal in the landfill.

Print Name: Paul E DeWitt

Signature: /s/: Signature on File

Date: $2 / 29 / 2012$

Radiological Survey Release for Waste Disposal RCT Initiais

This container/load meets the criteria for no added man-made radioactive material This container/load meets the criteria for

R. This container/load is exempt from survey due to expcess knowledge and origin. SIGNATURE:/S/: Signature on File FRM-0646 (08/06)

Note: "Food waste, office trash and animal carcasses do not require a radiological clearance. Freon-containing appliances must have signed removal certification statement with Load Verification."

SWO USE ONLY

Load Weight (net from scale or estimate): $45580 /$ Signature of Certifier: $/$ s/: Signature on File 


\begin{tabular}{llllll}
\hline SWO USE (Select One) & AREA & $\square 23$ & $\square 6$ & \9/10C & LANDFILL
\end{tabular}

For waste characterization, approval, and/or assistance, contact Solid Waste Operation (SWO) at 5-7898. REQUIRED: WASTE GERERATOR INFORMATION

(This form is for rolloffs, dump trucks, and other onsite disposal of materials.)

Waste Generator: Rebecca King Phone Number: $5-5804$

Location / Origin: Area \#25, CAU 562 CAS 25-60-04

\begin{tabular}{|c|c|c|c|c|}
\hline \multicolumn{2}{|c|}{ Waste Category: (check one) } & \multirow{2}{*}{$\begin{array}{l}\square \text { Commercial } \\
\square \text { Putrescrible }\end{array}$} & \multicolumn{2}{|l|}{$\triangle$ Industrial } \\
\hline Waste Type: & $\square$ NTS & & $\triangle$ FFACO-onsite & $\square$ \\
\hline (check one) & $\square$ Non-Putrescible & $\square$ Asbestos Containing Material & $\square \mathrm{FF}$ & $\square \mathrm{Hi}$ \\
\hline \multicolumn{2}{|c|}{ Pollution Prevention Category: (check one) } & $\triangle$ Environmental management & $\square$ Defense Projects & $\square$ YMP \\
\hline \multicolumn{2}{|c|}{ Pollution Prevention Category: (check one) } & $\triangle$ Clean-Up & $\square$ Routine & \\
\hline \multicolumn{2}{|c|}{ Method of Characterization: (check one) } & Sampling & & \\
\hline
\end{tabular}

Prohibited Waste at all three Radioactive waste; RCRA waste; Hazardous waste; Free liquids, PCBs above TSCA regulatory NTS landfills:

Additional Prohibited Waste at the Area 9 U10C Landfill: levels, and Medical wastes (needles, sharps, bloody clothing).

Sewage Sludge, Animal carcasses, Wet garbage (food waste); and Friable asbestos

\section{REQUIRED: WASTE CONTENTS ALLOWABLE WASTES}

Check all allowable wastes that are contained within this load:

NOTE: Waste disposal at the Area 6 Hydrocarbon Landfill must have come into contact with petroleum hydrocarbons or coolants, such as: gasoline (no benzene, lead); jet fuel; diesel fuel; lubricants and hydraulics; kerosene; asphaltic petroleum hydrocarbon; and ethylene glycol.
Acceptable waste at any NTS landfill:
$\square$ Paper
$\bigotimes$ Rocks / unaltered geologic materials
$\square$ Asphalt
$\bigotimes$ Metal
$\bigotimes$ Wood
$\bigotimes$ Soil
$\square$ Rubber (excluding tires)
$\square$ Plastic
Cable
$\square$ Cloth
$\square$ Insulation (non-Asbestosform)
$\bigotimes$ Demolition debris

Manufactured items: (swamp coolers, furniture, rugs, carpet, electronic components, PPE, etc.)
Additional waste accepted at the Area 23 Mercury Landfill:
Office Waste
Food Waste
Animal Carcasses
$\square$ Asbestos
Friable
Non-Friable (contact SWO if regulated load)
Quantity:

\section{Additional waste accepted at the Area 9 U10c Landfill:}
$\square$ Non-friable asbestos
$\square$ Drained automobiles and military vehicles
Solid fractions from sand/oil/water
$\square$ Light ballasts (contact SWO)
Drained fuel filters (gas \& diesel)
Deconned Underground and Above
Hydrocarbons (contact SWO)
Other
Ground Tanks

\section{Additional waste accepted at the Area 6 Hydrocarbon Landfill:
$\square$ Septic sludge
$\square$ Rags
$\square$ Drained fuel filters (gas \& diesel)
Crushed non-teme plated oil filters
Plants
Soil
Sludge from sand/oil/water separators
$\triangle \mathrm{PCBs}$ below 50 parts per million

Initials: ___ (if initialed, no radiological clearance is necessary.)

The above mentioned waste was generated outside of a Controlled Waste Management Area (CWMA) and to the best of my knowledge, does not contain radiological materials.

To the best of my knowledge, the waste described above contains only those mat site. I have verified this through the waste characterization method identified abo I prohibited and allowable waste items. I have contacted Property Management and is approved for disposal in the landfill.

Print Name: Paul E DeWitt

Signature: /s/: Signature on File

Date: $2 / 29 / 201$

Note: "Food waste, office trash and animal carcasses do not require a radiological c must have signed removal certification statement with Load Verification."
Radiological Survey Release for Waste Disposal RCT Initials This container/load meets the criteria for no added man-made radioactive material This container/load meets the criteria for

Radcon Manual Table 4.2 release limits.

D. This container/load is exempt from survey due to rocess knowledge and origin. SIGNATURE/S/: Signature on File DATE: $224 \mathrm{in}$ FRM-0646 (08/06)

SWO USE ONLY
Load Weight (net from scale or estimate): $44560^{\sqrt{ }}$ Signature of Certifier: ${ }_{-}^{\text {s/: Signature on File }}$ 


\begin{tabular}{|llllll}
\hline SWO USE (Select One) & AREA & $\square 23$ & $\square 6$ & \9/10C & LANDFILL
\end{tabular}

For waste characterization, approval, and/or assistance, contact Solid Waste Operation (SWO) at 5-7898.

\section{REQUIRED: WASTE GERERATOR INFORMATION}

(This form is for rolloffs, dump trucks, and other onsite disposal of materials.)

Waste Generator: Rebecca King Phone Number: 5-5804

Location / Origin: Area 23 CAU 562 CAS 23-99-06

Waste Category: (check one)

Waste Type: $\bigotimes$ NTS

(check one)

$\square$ Non-Putrescible

$\square$ Commercial
$\square$ Putrescrible
$\square$ Asbestos Containing Material

Pollution Prevention Category: (check one) $\bigotimes$ Environmental management Pollution Prevention Category: (check one) $\bigotimes$ Clean-Up Method of Characterization: (check one) \ Sampling \& Analysis

$\bigotimes$ Industrial

$\triangle$ FFACO-onsite

$\square$ WAC Exception

Prohibited Waste at all three NTS landfills:

Additional Prohibited Waste at the Area 9 U10C Landfill:

Radioactive waste; RCRA waste; Hazardous waste; Free liquids, PCBs above TSCA regulatory levels, and Medical wastes (needles, sharps, bloody clothing).

Sewage Sludge, Animal carcasses, Wet garbage (food waste); and Friable asbestos

\section{REQUIRED: WASTE CONTENTS ALLOWABLE WASTES}

Check all allowable wastes that are contained within this load:

NOTE: Waste disposal at the Area 6 Hydrocarbon Landfill must have come into contact with petroleum hydrocarbons or coolants, such as: gasoline (no benzene, lead); jet fuel; diesel fuel; lubricants and hydraulics; kerosene; asphaltic petroleum hydrocarbon; and ethylene glycol.
Acceptable waste at any NTS landfill:
$\square$ Paper
$凶$ Rocks / unaltered geologic materials
$\bigotimes$ Soil
$\square$ Rubber (excluding tires)
Empty containers
$\square$ Asphalt
$\triangle$ Metal
$\square$ Wood
$\square$ Cloth
$\square$ Insulation (non-Asbestosform)
$\square$ Demolition debris
$\square$ Plastic $\square$ Wire $\quad \square$ Cable
Manufactured items: (swamp coolers, furniture, rugs, carpet, electronic components, PPE, etc.)
Additional waste accepted at the Area 23 Mercury Landfill: $\square$ Office Waste
$\square$ Asbestos
Friable
Non-Friable (contact SWO if regulated load)
$\square$ Food Waste
Cement \& concrete
Quantity:
Animal Carcasses

Additional waste accepted at the Area 9 U10c Landfill:
$\square$ Non-friable asbestos
$\square$ Drained automobiles and military vehicles
$\square$ Light ballasts (contact SWO) $\square$ Drained fuel filters (gas \& diesel)
$\bigotimes$ Hydrocarbons (contact SWO)
Other

Solid fractions from sand/oil/water

Deconned Underground and Above Ground Tanks

\section{Additional waste accepted at the Area 6 Hydrocarbon Landfill:}
$\square$ Septic sludge
$\square$ Rags
$\square$ Drained fuel filters (gas \& diesel)
$\square$ Crushed non-teme plated oil filters
Plants
Soil
$\square$ Sludge from sand/oil/water separators
$\square$ PCBs below 50 parts per million REQUIRED: WASTE GENERATOR SIGNATURE

Initials: (if initialed, no radiological clearance is necessary.)

The above mentioned waste was generated outside of a Controlled Waste Man knowledge, does not contain radiological materials.

To the best of my knowledge, the waste described above contains only those $r$ site. I have verified this through the waste characterization method identified : prohibited and allowable waste items. I have contacted Property Management is approved for disposal in the landfill.

Print Name: Brian Konrad

Signature: /s/: Signature on File

Date: $3 / 06 / 12$

Radiological Survey Release for Waste Disposal RCT Initials

This container/load meets the criteria for no added man-made radioactive material This container/load meets the criteria for

C. Radcon Manual Table 4.2 release limits. This container/load is exempt from survey due tQdiacess knowledae and origin SIGNATURE:/S/: Signature on File DATE: $3 / \mathrm{C} / \mathrm{l} / 2$ FRM-0646 (08/06)

Note: "Food waste, office trash and animal carcasses do not require a radiological clearance. Freon-containing appliances must have signed removal certification statement with Load Verification."

\section{SWO USE ONLY}

Load Weight (net from scale or estimate): Signature of Certifier: /s/: Signature on File 


\begin{tabular}{llllll}
\hline SWO USE (Select One) & AREA & $\square 23$ & $\square 6$ & \9/10C & LANDFILL
\end{tabular}

For waste characterization, approval, and/or assistance, contact Solid Waste Operation (SWO) at 5-7898.

REQUIRED: WASTE GERERATOR INFORMATION

(This form is for rolloffs, dump trucks, and other onsite disposal of materials.)

Waste Generator: Rebecca King

Phone Number: $5-5804$

Location / Origin: CAU 562 Area 2

\begin{tabular}{llll} 
Waste Category: (check one) & $\square$ Commercial & $\square$ Industrial \\
\hline $\begin{array}{l}\text { Waste Type: } \quad \square \text { NTS } \\
\text { (check one) }\end{array} \quad \square$ Non-Putrescible & $\square$ Asbestos Containing Material $\square$ FFACO-offsite & $\square$ Historic DOE/NV \\
\hline Pollution Prevention Category: (check one) & $\square$ Environmental management & $\square$ Defense Projects \\
\hline Pollution Prevention Category: (check one) & $\square$ Clean-Up & $\square$ YMP \\
\hline Method of Characterization: (check one) & $\square$ Sampling \& Analysis & $\square$ Routine \\
\hline
\end{tabular}

Prohibited Waste at all three Radioactive waste; RCRA waste; Hazardous waste; Free liquids, PCBs above TSCA regulatory NTS landfills:

Additional Prohibited Waste at the Area 9 U10C Landfill: levels, and Medical wastes (needles, sharps, bloọdy clothing).

Sewage Sludge, Animal carcasses, Wet garbage (food waste); and Friable asbestos

REQUIRED: WASTE CONTENTS ALLOWABLE WASTES

Check all allowable wastes that are contained within this load:

NOTE: Waste disposal at the Area 6 Hydrocarbon Landfill must have come into contact with petroleum hydrocarbons or coolants, such as: gasoline (no benzene, lead); jet fuel; diesel fuel; lubricants and hydraulics; kerosene; asphaltic petroleum hydrocarbon; and ethylene glycol.
Acceptable waste at any NTS landfill:
$\bigotimes$ Paper
$\square$ Rocks / unaltered geologic materials
Empty containers
$\square$ Asphalt $\square$ Metal
$\square$ Wood
$\square$ Soil
$\square$ Rubber (excluding tires)
$\square$ Plastic
$\square$ Wire
Cable
$\triangle$ Cloth
$\square$ Insulation (non-Asbestosform)
$\square$ Demolition debris

Manufactured items: (swamp coolers, furniture, rugs, carpet, electronic components, PPE, etc.)

Additional waste accepted at the Area 23 Mercury Landfill: $\quad \square$ Office Waste $\square$ Food Waste $\square$ Animal Carcasses

Asbestos $\quad \square$ Friable $\quad \square$ Non-Friable (contact SWO if regulated load) Quantity:

Additional waste accepted at the Area 9 U10c Landfill:
$\triangle$ Non-friable asbestos
$\square$ Drained automobiles and military vehicles
$\square$ Light ballasts (contact SWO)
$\square$ Drained fuel filters (gas \& diesel)
Solid fractions from sand/oil/water
Hydrocarbons (contact SWO)
Other
Deconned Underground and Above Ground Tanks

\begin{tabular}{|c|c|c|c|}
\hline \multicolumn{4}{|c|}{ Additional waste accepted at the Area 6 Hydrocarbon Landfill: $\quad \square$} \\
\hline$\square$ Septic sludge & $\square$ Rags & $\square$ Drained fuel filters (gas \& diesel) & $\square$ Crushed non-teme plated oil filters \\
\hline$\square$ Plants & $\square$ Soil & $\square$ Sludge from sand/oil/water separators & $\square$ PCBs below 50 parts per million \\
\hline
\end{tabular}

Initials:- ' (if initialed, no radiological clearance is necessary.)

The above mentioned waste was generated outside of a Controlled Waste Man knowledge, does not contain radiological materials.

To the best of my knowledge, the waste described above contains only those site. I have verified this through the waste characterization method identified prohibited and allowable waste items. I have contacted Property Management is approved for disposal in the landfill.

Print Name: Brian Konrad

Radiological Survey Release for Waste Disposal RCT Initials

This container/load meets the criteria for no added man-made radioactive material This container/load meets the criteria for Radcon Manual Table 4.2 release limits.

DU. This containerlload is exempt from survey due toprogess knowledge and origin

SIGNATURE:/S/: Signature on File DATE: 3812 FRM-0646 (08/06)

Signature: /s/: Signature on File

_ Date: 3-08-12

"Radiological Release Sticker" here. Onsite use only.

Note: "Food waste, office trash and animal carcasses do not require a radiological clearance. Freon-containing appliances must have signed removal certification statement with Load Verification."

SWO USE ONLY

Load Weight (net from scale or estimate): $\$ 80$ Signature of Certifier: 


\begin{tabular}{llllll}
\hline SWO USE (Select One) & AREA & $\square 23$ & $\square 6$ & \9/10C & LANDFILL
\end{tabular}

For waste characterization, approval, and/or assistance, contact Solid Waste Operation (SWO) at 5-7898.

REQUIRED: WASTE GERERATOR INFORMATION

(This form is for rolloffs, dump trucks, and other onsite disposal of materials.)

Waste Generator: Rebecca King Phone Number: $5-5804$

Location / Origin: CAU 562, CAS 25-60-04 Area 25

\begin{tabular}{|c|c|c|c|c|}
\hline \multicolumn{2}{|c|}{ Waste Category: (check one) } & \multirow{2}{*}{$\begin{array}{l}\square \text { Commercial } \\
\square \text { Putrescrible }\end{array}$} & \multicolumn{2}{|l|}{$\triangle$ Industrial } \\
\hline Waste Type: & $\triangle \mathrm{NTS}$ & & $凶$ FFACO-onsite & $\square$ WAC Exception \\
\hline (check one) & $\square$ Non-Putrescible & $\square$ Asbestos Containing Material & $\square$ FFACO-offsite & $\square$ Historic DOE/NV \\
\hline \multicolumn{2}{|c|}{ Pollution Prevention Category: (check one) } & $\bigotimes$ Environmental management & $\square$ Defense Projects & $\square \mathrm{YMP}$ \\
\hline \multicolumn{2}{|c|}{ Pollution Prevention Category: (check one) } & $\triangle$ Clean-Up & $\square$ Routine & \\
\hline \multicolumn{2}{|c|}{ Method of Characterization: (check one) } & \ Sampling \& Analysis & $\square$ Process Knowledg & $\square$ Contents \\
\hline
\end{tabular}

Additional Prohibited Waste at the Area 9 U10C Landfill:

Sewage Sludge, Animal carcasses, Wet garbage (food waste); and Friable asbestos

\section{REQUIRED: WASTE CONTENTS ALLOWABLE WASTES}

Check all allowable wastes that are contained within this load:

NOTE: Waste disposal at the Area 6 Hydrocarbon Landfill must have come into contact with petroleum hydrocarbons or coolants, such as: gasoline (no benzene, lead); jet fuel; diesel fuel; lubricants and hydraulics; kerosene; asphaltic petroleum hydrocarbon; and ethylene glycol.
Acceptable waste at any NTS landfill:
$\square$ Paper
$\triangle$ Rocks / unaltered geologic materials
\Soil
$\square$ Rubber (excluding tires)
$\square$ Insulation (non-Asbestosform)
Plastic $\square$ Wire
$\square$ Cable
$\square$ Cloth
carpet,
electronic components, PPE, etc.
$\square$ Empty containers
$\square$ Demolition debris
$\square$ Cement \& concrete
Additional waste accepted at the Area 23 Mercury Landfill: $\quad \square$ Office Waste
$\square$ Asbestos
$\square$ Friable
Non-Friable (contact SWO if regulated load)
$\square$ Food Waste
Quantity:

Additional waste accepted at the Area 9 U10c Landfill:
$\square$ Non-friable asbestos
$\square$ Drained automobiles and military vehicles
$\square$ Light ballasts (contact SWO)
$\square$ Drained fuel filters (gas \& diesel)
Solid fractions from sand/oil/water
Hydrocarbons (contact SWO) $\bigotimes$ Other PCB impacted soil less than 4ppm
Deconned Underground and Above Ground Tanks
Additional waste accepted at the Area 6 Hydrocarbon Landfill:
$\square$ Septic sludge
$\square$ Rags
Plants
Soil
$\square$ Drained fuel filters (gas \& diesel)
$\square$ Sludge from sand/oil/water separators
Crushed non-teme plated oil filters REQUIRED: WASTE GENERATOR SIGNATURE

Initials: (if initialed, no radiological clearance is necessary.)

The above mentioned waste was generated outside of a Controlled Waste Manas knowledge, does not contain radiological materials.

To the best of my knowledge, the waste described above contains only those $\mathrm{m}$ : site. I have verified this through the waste characterization method identified ab prohibited and allowable waste items. I have contacted Property Management a is approved for disposal in the landfill.

Print Name: Brian Konrad

Signature: /s/: Signature on File

Date: $3 / 12 / 12$

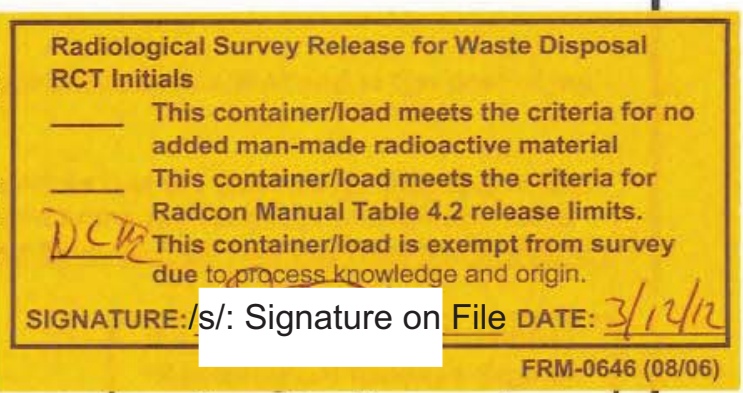

FRM-0646 (08/06)

Note: "Food waste, office trash and animal carcasses do not require a radiological clearance. Freon-containing appliances must have signed removal certification statement with Load Verification."

\section{SWO USE ONLY}

Load Weight (net from scale or estimate) $3 / 3, \mathrm{Cic}$ 
Please print or type. (Form designéd for use of elite (12-pitch) typewriter.)

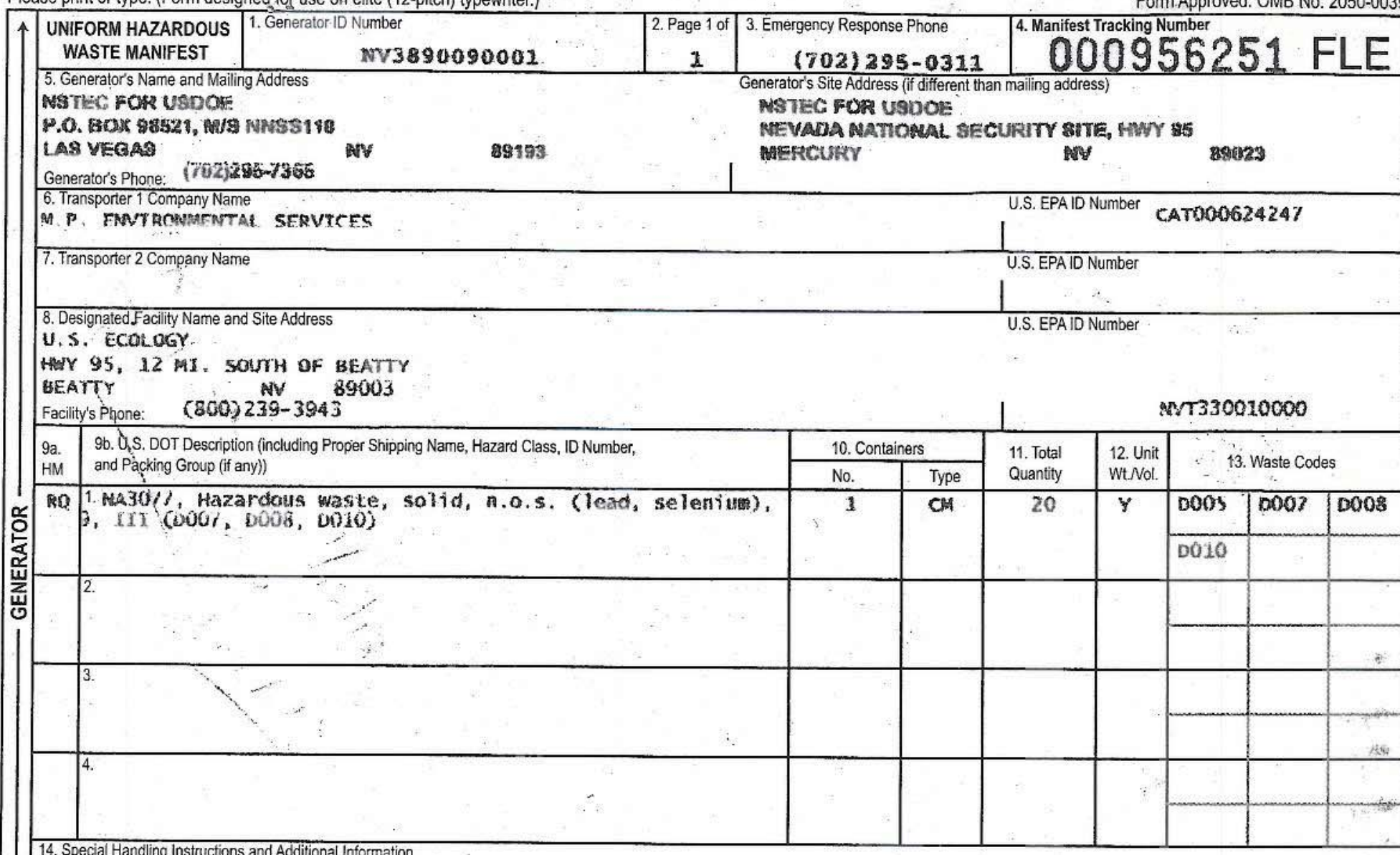

14. Special Handling Instructions and Additional Information

1. ERG 131; BTN 4834 MNS-NS5-12-0027; PROFILE 13-1817. LOAD A12003.

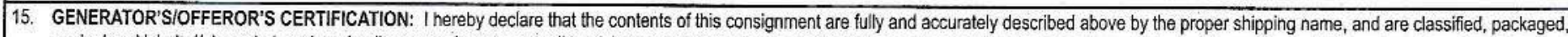
marked and labeled/placarded, and are in all respects in proper condition for transport according to applicable international and national governmental regulations. If export shipment and I am the Primary

Exporter, I certify that the contents of this consignment conform to the terms of the attached EPAAcknowledgment of Consent.

I certify that the waste minimization statement identified in 40 CFR 262.27(a) (if I am a large quantity generator) or (b) (if I am a small quantity generator) is true.

\section{Generator's/Offero's Printed/Typed Name}

CITILO CARLOS GONZALES

Transporter signature (for exports only):

Import to U.S

ON BEMALF OF USDOE

Is/: Signature on File

$\square$ Export from U.S.

17. Transporter Acknowledgment of Receipt of Materials

Transporter 1 Printed/Typed Name

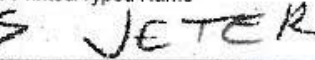

18. Discrepancy

18a. Discrepancy Indication Space

$\square$ Quanitity

$\square$ Type

要

18b. Alternate Facility (or Generator)

Facility's Phone:

18c. Signature of Alternate Facility (or Generator)

19. Hazardous Waste Report Management Method Codes (i.e., codes for hazardous waste treatment, disposal, and recycling systems)

Port of entry/exit:

Date leaving U.S.

20. Designated Facility Owner or Operator: Certification of receipt of hazardous materials coverediby the manifest except as noted in ltem 18a 


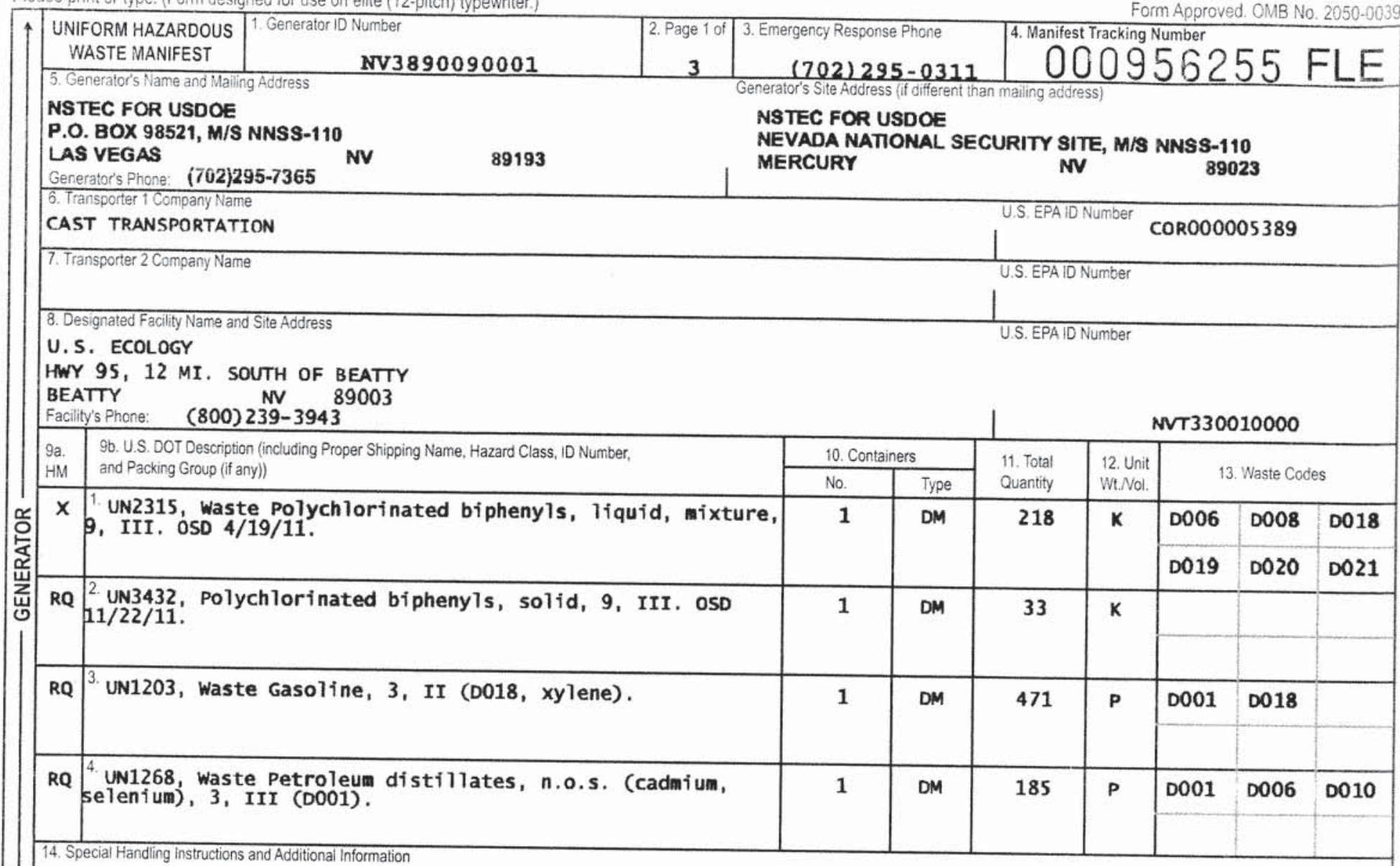

1. ERG $171 ;$ NS-NSS-11-0068;D022 THRU D043; \#070178976-0. 2. ERG $171 ; 12-0014 ; \# 13-1022$. 3 . ERG $128 ; 11-0079 ; \# 13-9713$.
4. ERG $128 ; 12-0003 ; \# 13-0955$. LOAD \#12001.

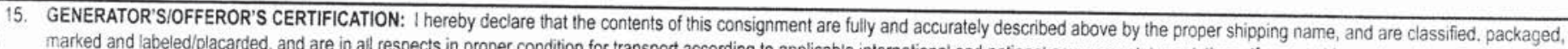
marked and labeled/placarded, and are in all respects in proper condition for transport according to applicable international and national governmental regulations. If export shipment and I am the Primary Exporter, I certify that the contents of this consignment conform to the terms of the attached EPA Acknowledgment of Consent.

I certify that the waste minimization statement identified in 40 CFR 262.27(a) (if I am a large quantity generator) or (b) (if I am a small quantity generator) is Irue. Generator's/Offeror's Printed/Typed Name

CIRILO CARLOS GONZALES

16. International Shipments
Transporter signature (for exports only):

$\square$ Import to U.S.

ON BEHALF OF USDOE

(/s/: Signature on File

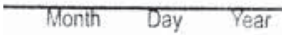

17. Transporter Acknowledgment of Receipt of Materials

Transporter 1 Printed/Typed Name

Transporter 2 Printed/Typed Name

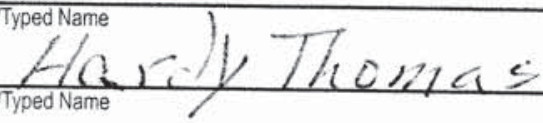

$\square$ Export from U.S.

Port of entrylexit: Date leaving U.S.

18. Discrepancy

18a. Discrepancy Indication Space

$\square$ Quantity

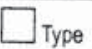

$\square$ Residue

$\square$ Partial Rejection

Full Rejection

18b. Alternate Facility (or Generator)

Manifest Reference Number:

Facility's Phone:

18c. Signature of Alternate Facility (or Generator)

19. Hazardous Waste Report Management Method Codes (i.e., codes for hazardous waste treatment, disposal, and recycling systems)

\section{$H / 41 I^{2} H / 32$}

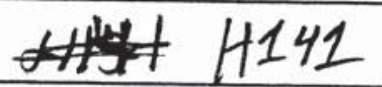

20. Designated Facility Owner or Operator: Certification of receipt of hazardous materials covered by the manifest except as noted in Item $18 \mathrm{a}$

ture 
Please print or type. (Form designed for use on elite (12-pitch) typewriter.)

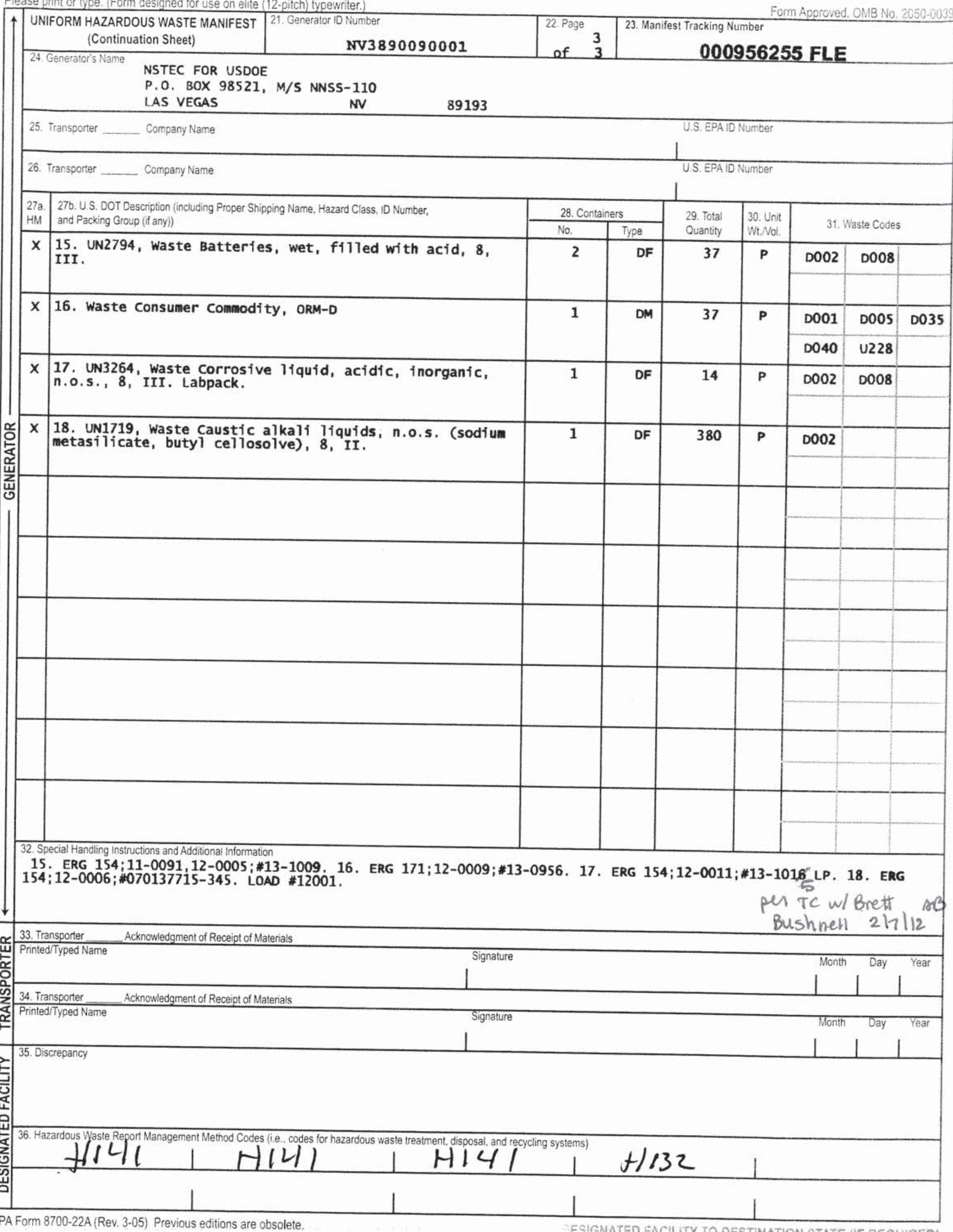


Bock $\$ 1$

Please print or type. (Form designed for use on elite (12-pitch) typewriter.)

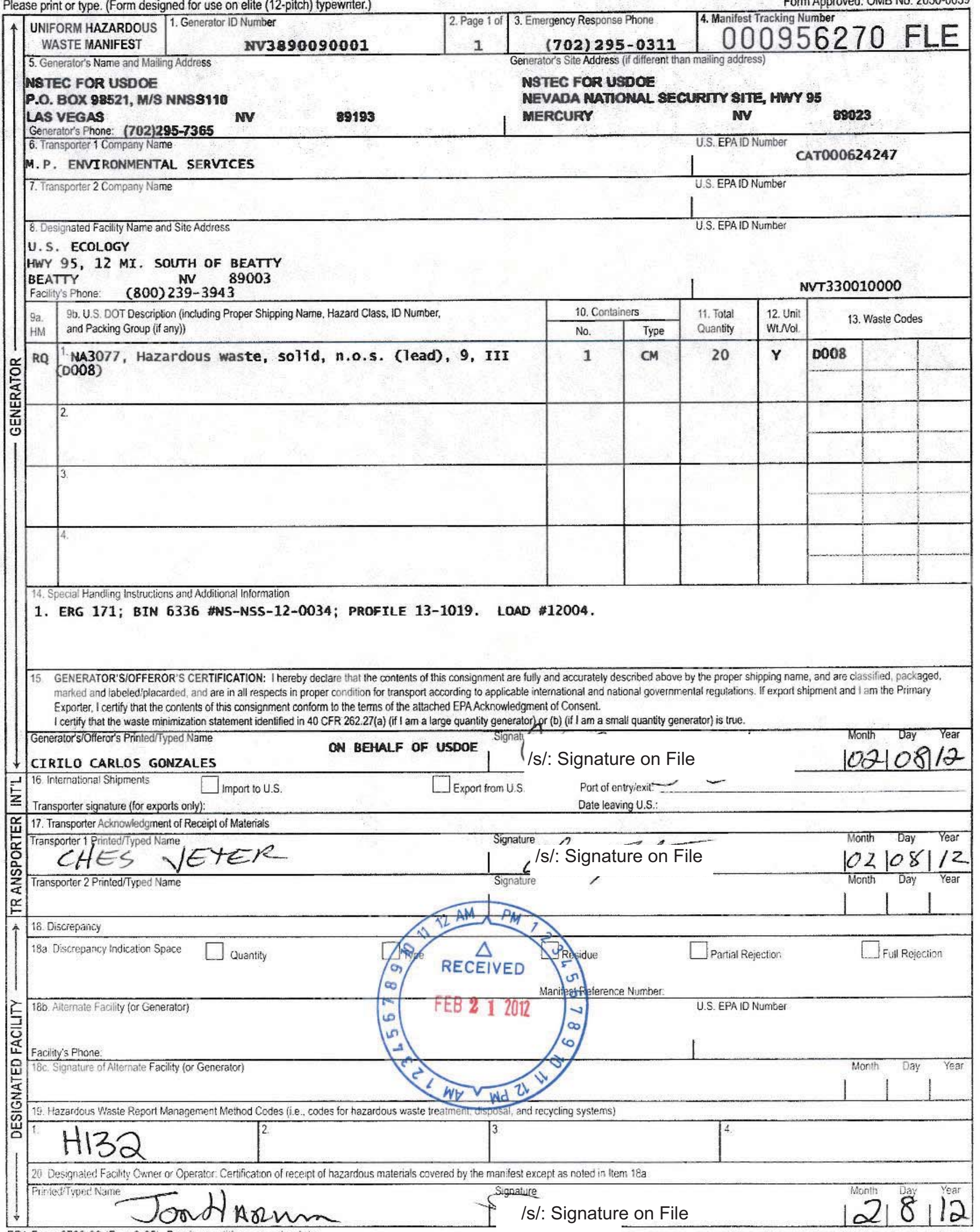




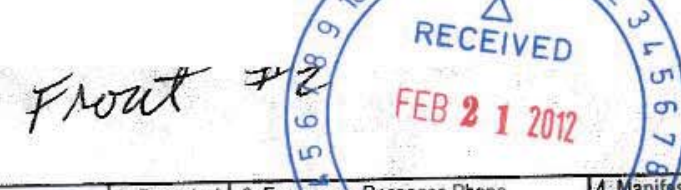

Please print or type. (Form designed for use on elite (12-pitch) typewriter.)

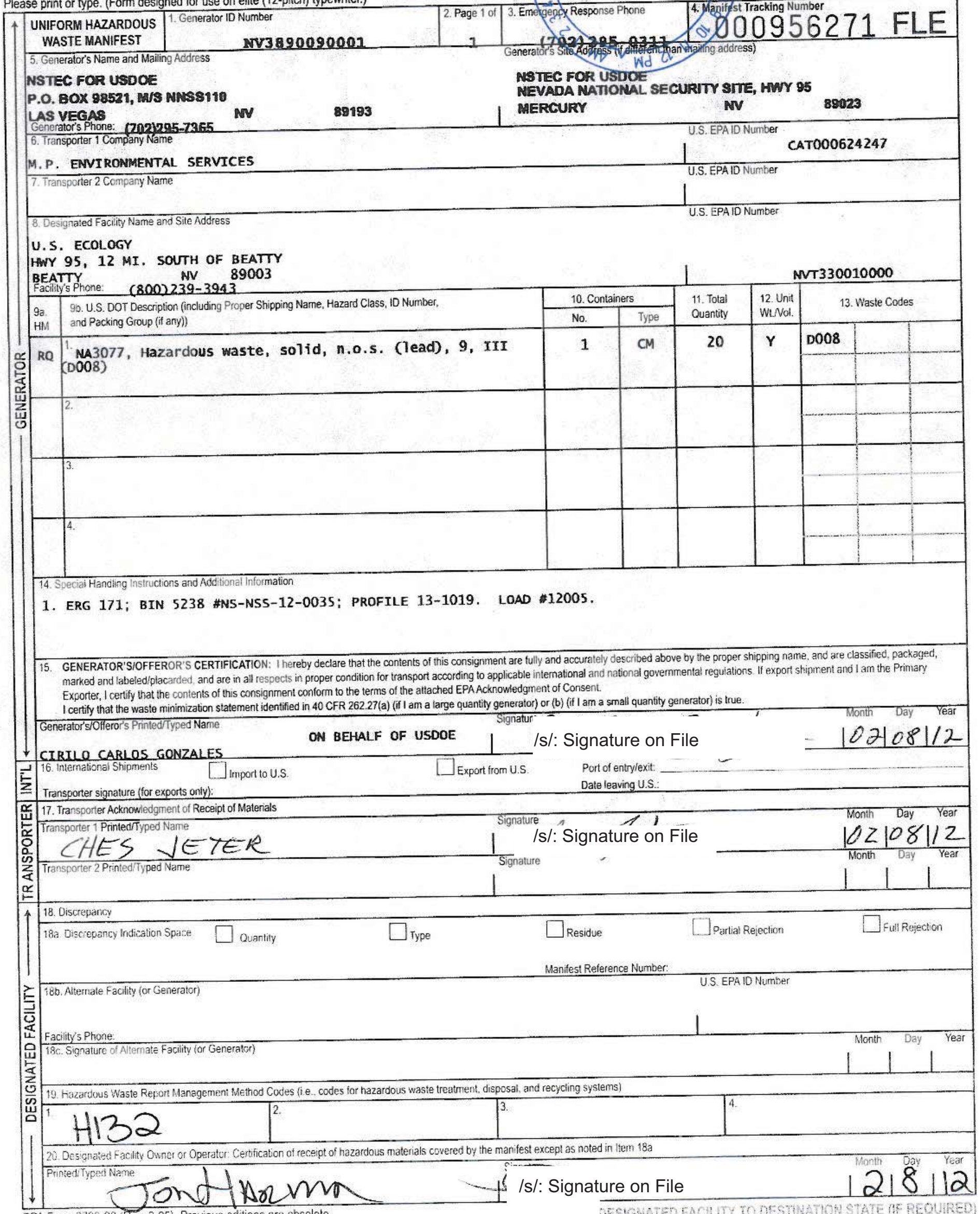




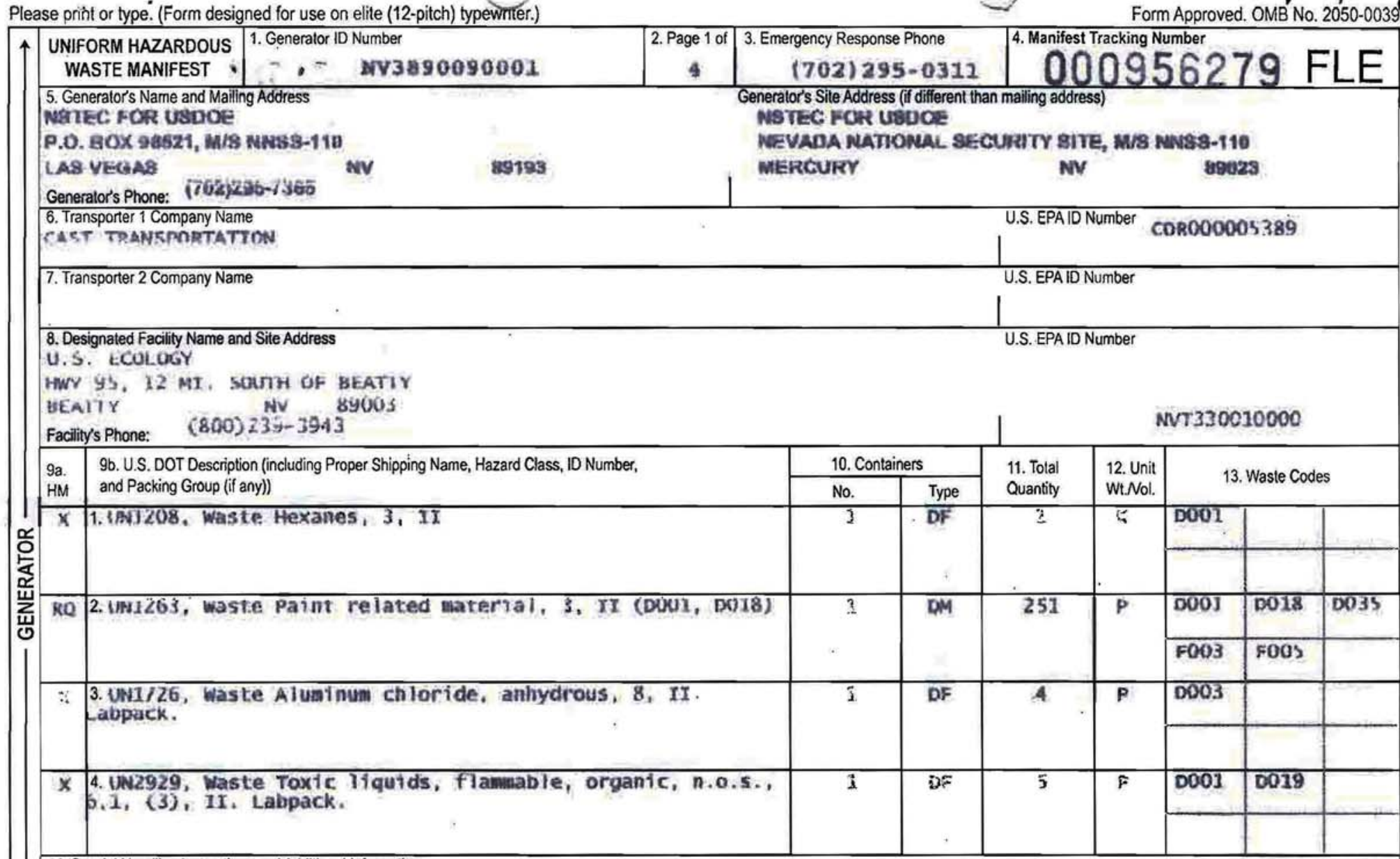

14. Special Handling Instructions and Additional Information

1. ERG 128; PKGE 12-0052; PCB OSD 3/26/12; IP 13-1015. 2. ERG 128; 12-0038; 13-0955. 3. ERG 137; 12-0039; LP 131015. 4. ERG 13i; 12-0040; LP 13-1013. LOAD \#12009.

15. GENERATOR'S/OFFEROR'S CERTIFICATION: I hereby declare that the contents of this consignment are fully and accurately described above by the proper shipping name, and are classified, packaged marked and labeled/placarded, and are in all respects in proper condition for transport according to applicable international and national governmental regulations. If export shipment and I am the Primary Exporter, 1 certify that the contents of this consignment conform to the terms of the attached EPA Acknowledgment of Consent.

I certify that the waste minimization statement identified in 40 CFR 262.27(a) (if I am a large quantity generator) or (b) (if I am a small quantity generator) is true.

Generator's/Offeror's Printed/Typed Name ON BEMALF OF USDOE Signature/T Y

CXKILO Carlós GONZALES

Transporter signature (for exports only):

$\square$ Import to U.S

/s/: Signature on File

17. Transporter Acknowledgment of Receipt of Materials

Transporter 1 Printed/Typed Name

ENir Qhern

Transporter 2 Printed/Typed Name

- Port of entrylexit:

18. Discrepancy

18a. Discrepancy Indication Space

$\square$ Quantity

$\square$ Type

$\square$ Residue

Partial Rejection

Full Rejection

18b. Alternate Facility (or Generator)

Manifest Reference Number:

Facility's Phone:

18c. Signature of Altemate Facility (or Generator)

19. Hazardous Waste Report Management Method Codes (i.e., codes for hazardous waste trealment, disposal, and recycling systems) .

\begin{tabular}{l|l|l|l|l|l|l|}
\hline 1.41 & 11141
\end{tabular}

20. Designaled Facility Owner or Operator: Certification of receipt of hazardous materials covered by the manifest except as noted in ltem 18 a

\section{Prinled/Typed Name $\quad$ S S S}


at. 2

Please print or type. (Form designed for use on elite (12-pitch) typewriter.)

\begin{tabular}{|c|c|c|c|c|}
\hline \multirow[t]{2}{*}{$\uparrow$} & \multicolumn{2}{|c|}{$\begin{array}{l}\text { UNIFORM HAZARDOUS WASTE MANIFEST } \\
\text { (Continuation Sheet) }\end{array}$} & \multicolumn{2}{|c|}{$\begin{array}{l}\text { 21. Generator ID Number } \\
\qquad \text { NY3890090061. }\end{array}$} \\
\hline & 24. Generator's Name & $\begin{array}{l}\text { NSTEC FOR USDOE } \\
\text { P. O. BOX } 98521 \text {. } \\
\text { L.AS VEGAS }\end{array}$ & $\begin{array}{c}\text { M/S HWSS }-110 \\
\text { NN }\end{array}$ & 89193 \\
\hline
\end{tabular}

\begin{tabular}{|lll|l}
\hline 25. Transporter & Company Name & U.S. EPAID Number \\
\hline 26. Transporter $\quad$ Company Name & U.S. EPAID Number
\end{tabular}

27a. $27 b$. U.S. DOT Description (including Proper Shipping Name, Hazard Class, ID Number,

HM and Packing Group (if any))

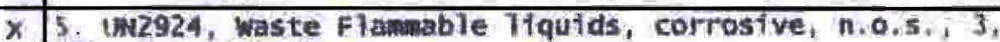
(8), II. Labpack.

\section{Page 2}

23. Manifest Tracking Number

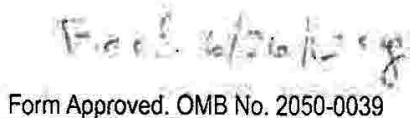

000956279 FLE

6. UN1760, waste corrostve jiquids, n.0.5., 8, II. Labpark,

X 7, UNIS93, Waste Dtch loromethane, b.I, ITI. Tox:C. Labpack.

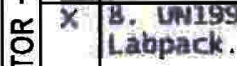

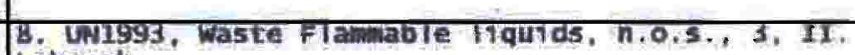

.6 9. UN1992, Waste Flamable Tiquid, toxic, n.0.5., 3, (6.1). II, Labpack.

\& 10. MA3082, Hazardous waste, 17quTd, n.0.s, (ep7nephrine), 9. III.

$x$ 11. NA3077, Hazardous waste, solkd, n,0.5. (benzene), 9, Iri.

$x$ 12. Maso77, Hazardous waste, solfd, n.0.s, (chroutrili, 7ead), 9, iII.

2. 13. Na3077, Hazardous waste, soltd, n.0.5, (cadaium, lead). 9, III.

2 14. NA3082, Hazardous waste, Iqujd, n.0.5. Ccadmina, 1ead), 9 , III.

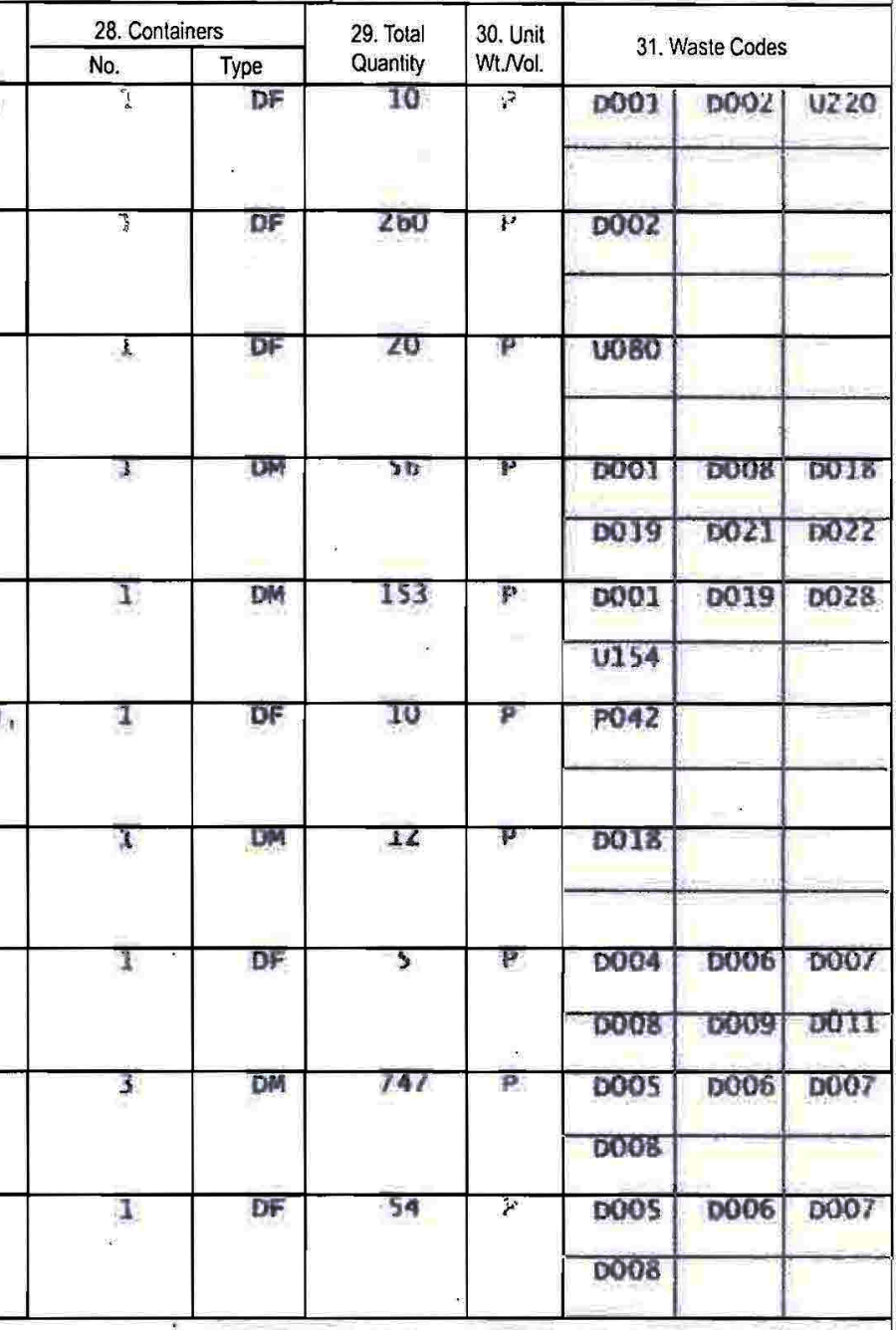

32. Special Handling Instructions and Additional Information 6 . ERG 154; 12-0060; LP 13-1015. 7. ERG 160; 12-0047; LP 13-1015. 8, ERG 128; $12-0053$; CODES D028, D029, 0035, 0039, D040, 0043, v002, U154; t? 13-1015, 9, ERG 131; 12-0056; LP 13-1015, 10.

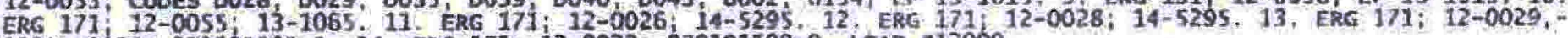
$0030,-0031 ;$ 070191191-1, 14, ERE 171; 12-0032; 070191190-0. LOAD \#12009.

33. Transporter Acknowledgment of Receipt of Materials

(34.

34. Transporter Acknowledgment of Receipt of Materials

Printed/Typed Name

Signature

35. Discrepancy

36. Hazardous. Waste Report Management Method Codes (i.e., codes for hazardous waste treatment, disposal, and recycling systems)

$11 \div 4 ! \mid 11 ! 4 !$

1141

H.141

11132

H141 
$f$

Please print or type. (Form designed for use on elite (12-pilch) typewriter.)

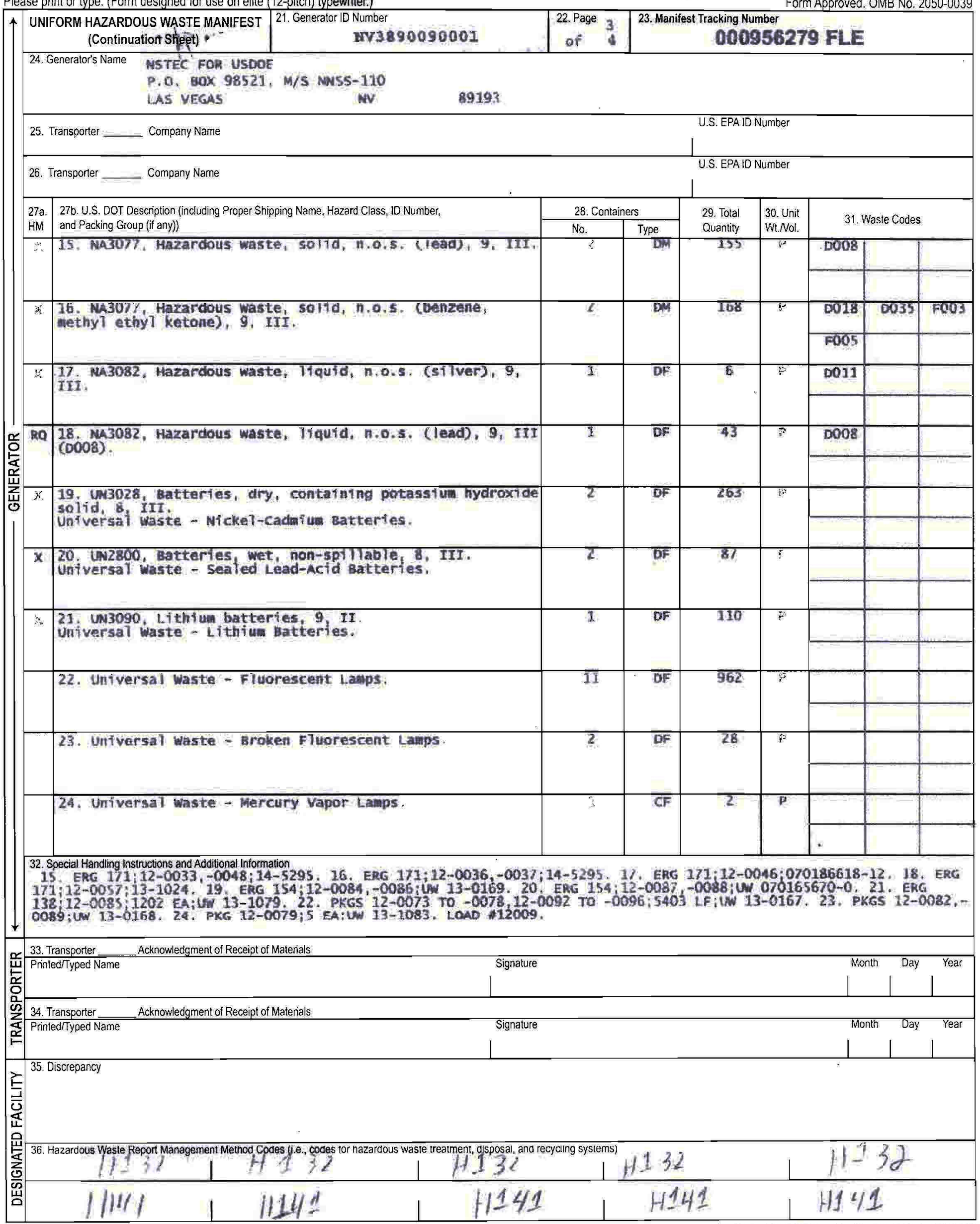


24. Generator's Name NSTEC FOR USDOE

25. Transporter Company Name U.S. EPA ID Number

26. Transporter Company Name U.S. EPA ID Number

27a. 27b. U.S. DOT Description (including Proper Shipping Name, Hazard Class, ID Number,

HM and Packing Group (if any))

25. Untversal Waste - Sodiun Laaps.

26. Universal waste - Metal Halide Laaps.

3. Non-DOT, Non-RCW Ragulated, LiquTas.

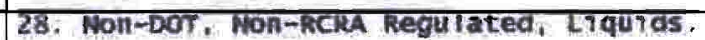

29. NOI-DOT, Non-RCIRA Regulated, LTquYas,

32. Special Handling Instructions and Additional Information. S2 LAMPS; Uw 13-1080, 26. PKGS 12-0081, -0090; 71 LAMPS; UW 13-1074, 27, PKG 12$0062 ;$ L.P 13-7747. 28. PKG 12-0063; LP 13-7747, 29. PKG 12-0065; LP 13-7747. LDMD *12009.

33. Transporter_ Acknowledgment of Receipt of Materials

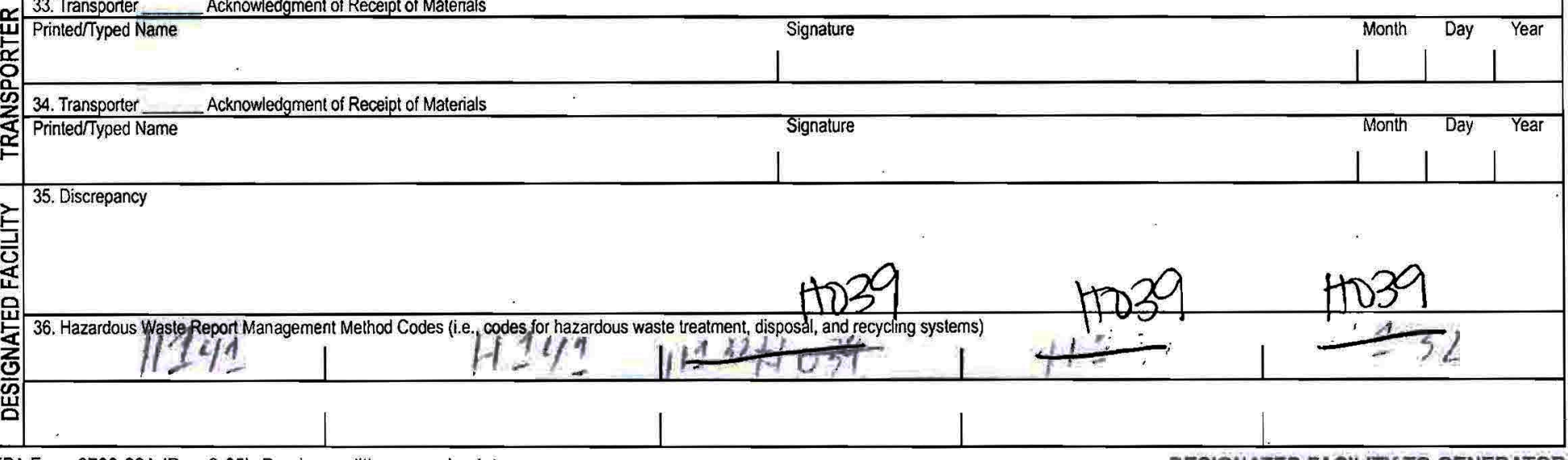


CAU 562 Closure Report

Section: Appendix C

Revision: 0

Date: August 2012

\section{THIS PAGE INTENTIONALLY LEFT BLANK}


CAU 562 Closure Report

Section: Appendix D

Revision: 0

Date: August 2012

APPENDIX D

\section{SITE CLOSURE PHOTOGRAPHS}


CAU 562 Closure Report

Section: Appendix D

Revision: 0

Date: August 2012

THIS PAGE INTENTIONALLY LEFT BLANK 


\section{Photograph Log}

\begin{tabular}{|c|c|c|c|}
\hline $\begin{array}{c}\text { PHOTOGRAPH } \\
\text { NUMBER }\end{array}$ & DATE & CORRECTIVE ACTION SITE & DESCRIPTION \\
\hline 1 & $10 / 26 / 2011$ & CAS 02-26-11, Lead Shot & Before Closure Activities \\
\hline 2 & $10 / 26 / 2011$ & CAS 02-26-11, Lead Shot & During Closure Activities \\
\hline 3 & $01 / 18 / 2012$ & CAS 02-26-11, Lead Shot & After Closure Activities \\
\hline 4 & $11 / 01 / 2011$ & CAS 02-44-02, Paint Spills and French Drain & Asbestos Tile \\
\hline 5 & $11 / 01 / 2011$ & CAS 02-44-02, Paint Spills and French Drain & After Removal of Asbestos \\
\hline 6 & $11 / 30 / 2011$ & CAS 02-44-02, Paint Spills and French Drain & Paint Rack \\
\hline 7 & $11 / 30 / 2011$ & CAS 02-44-02, Paint Spills and French Drain & Paint Rack Removal \\
\hline 8 & $12 / 15 / 2011$ & CAS 02-44-02, Paint Spills and French Drain & Paint on Concrete Pads \\
\hline 9 & $01 / 12 / 2012$ & CAS 02-44-02, Paint Spills and French Drain & After Removal of Paint \\
\hline 10 & $06 / 06 / 2011$ & CAS 02-44-02, Paint Spills and French Drain & Small Building \\
\hline 11 & $01 / 03 / 2012$ & CAS 02-44-02, Paint Spills and French Drain & Removal of Small Building \\
\hline 12 & $01 / 03 / 2012$ & CAS 02-44-02, Paint Spills and French Drain & Removal of Small Building \\
\hline 13 & $12 / 15 / 2011$ & CAS 02-44-02, Paint Spills and French Drain & Soil Excavation \\
\hline 14 & $11 / 15 / 2011$ & CAS 02-59-01, Septic System & Pumping Liquid \\
\hline 15 & $11 / 15 / 2011$ & CAS 02-59-01, Septic System & Disposal of Liquid \\
\hline 16 & $12 / 07 / 2011$ & CAS 02-59-01, Septic System & Excavation of Tank \\
\hline 17 & $12 / 08 / 2011$ & CAS 02-59-01, Septic System & Tank after Removal of Lids \\
\hline 18 & $12 / 08 / 2011$ & CAS 02-59-01, Septic System & Solidification of Sludge \\
\hline 19 & $12 / 12 / 2011$ & CAS 02-59-01, Septic System & Removal of Solidified Sludge and Tank \\
\hline 20 & $12 / 13 / 2011$ & CAS 02-59-01, Septic System & Excavation after Removal of Tank \\
\hline 21 & $04 / 02 / 2012$ & CAS 02-60-03, Steam Cleaning Drain & Backfilled Excavation \\
\hline 22 & $12 / 14 / 2011$ & CAS 02-60-05, French Drain & Excavation of Soil \\
\hline 23 & $12 / 14 / 2011$ & CAS 02-60-05, French Drain & Soil Excavation \\
\hline 24 & $04 / 02 / 2012$ & CAS 02-60-05, French Drain & Backfilled Excavation \\
\hline 25 & $01 / 19 / 2012$ & CAS 23-60-01, Mud Trap Drain and Outfall & Removal of Outfall Pipe \\
\hline 26 & $01 / 19 / 2012$ & CAS 23-60-01, Mud Trap Drain and Outfall & Mud Trap \\
\hline 27 & $01 / 19 / 2012$ & CAS 23-60-01, Mud Trap Drain and Outfall & Removal of Mud Trap \\
\hline 28 & $01 / 19 / 2012$ & CAS 23-99-06, Grease Trap & Before Removal of Sediment \\
\hline 29 & $01 / 19 / 2012$ & CAS 23-99-06, Grease Trap & After Removal of Sediment \\
\hline 30 & $01 / 19 / 2012$ & CAS 23-99-06, Grease Trap & Backfilled Grease Trap \\
\hline 31 & $01 / 23 / 2012$ & CAS 25-60-04, Building 3123 Outfalls & Outfall Pipe \\
\hline 32 & $01 / 23 / 2012$ & CAS 25-60-04, Building 3123 Outfalls & Outfall Pipe \\
\hline
\end{tabular}




\section{Photograph Log (CONTINUED)}

\begin{tabular}{|c|c|l|l||}
\hline $\begin{array}{c}\text { PhOTOGRAPH } \\
\text { Number }\end{array}$ & DATE & \multicolumn{1}{|c|}{ CORRECTIVE ACTION Site } & \multicolumn{1}{|c|}{ DeSCRIPTION } \\
\hline \hline 33 & $01 / 23 / 2012$ & CAS 25-60-04, Building 3123 Outfalls & After Removal of Outfall Pipe \\
\hline 34 & $01 / 24 / 2012$ & CAS 25-60-04, Building 3123 Outfalls & Excavation of Soil \\
\hline 35 & $03 / 13 / 2012$ & CAS 25-60-04, Building 3123 Outfalls & Excavation and Verification Sample Locations \\
\hline 36 & $03 / 20 / 2012$ & CAS 25-60-04, Building 3123 Outfalls & Backfilled Excavation \\
\hline
\end{tabular}




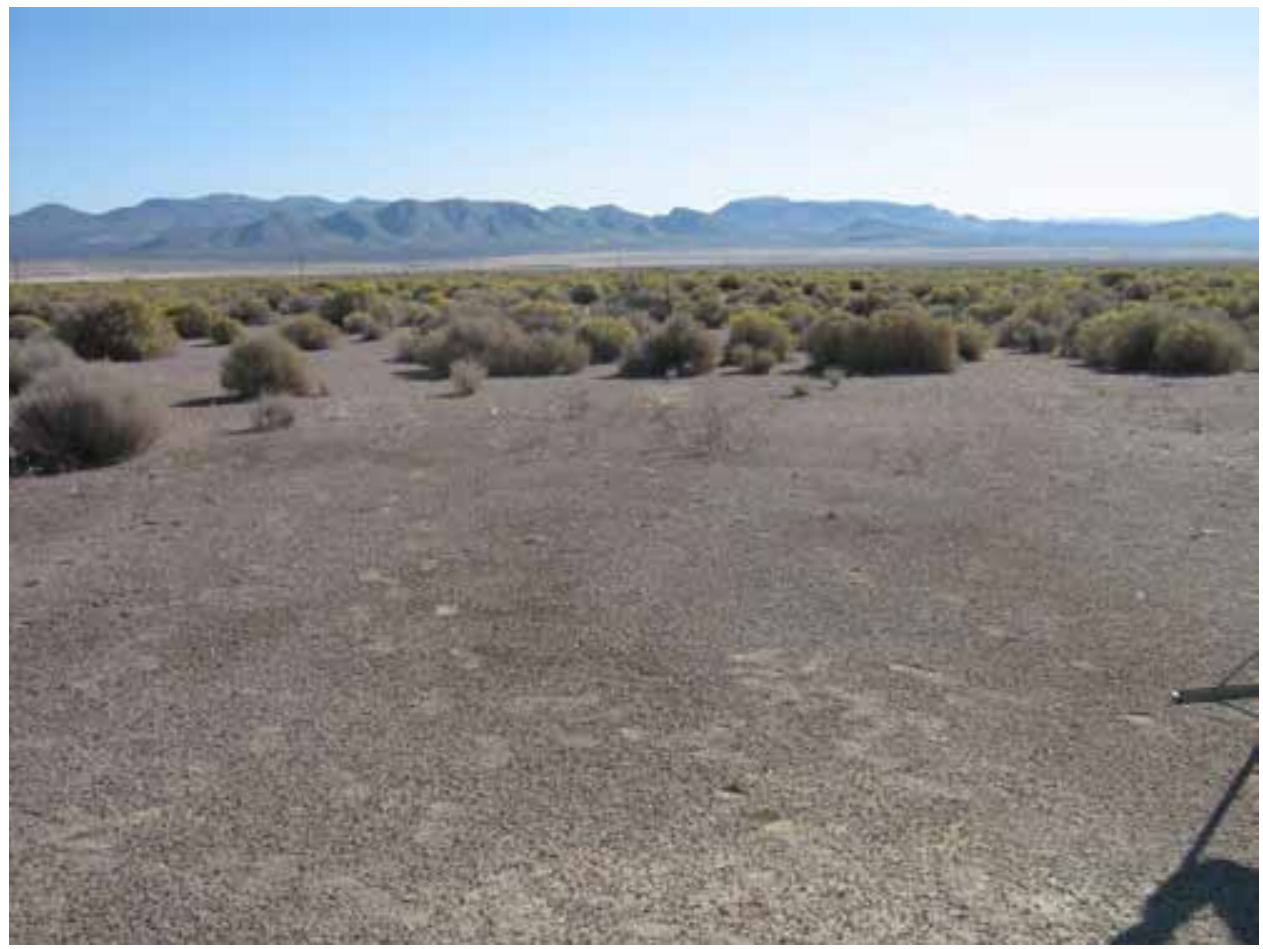

Photograph 1: CAS 02-26-11, Lead Shot, Before Closure Activities, 10/26/2011

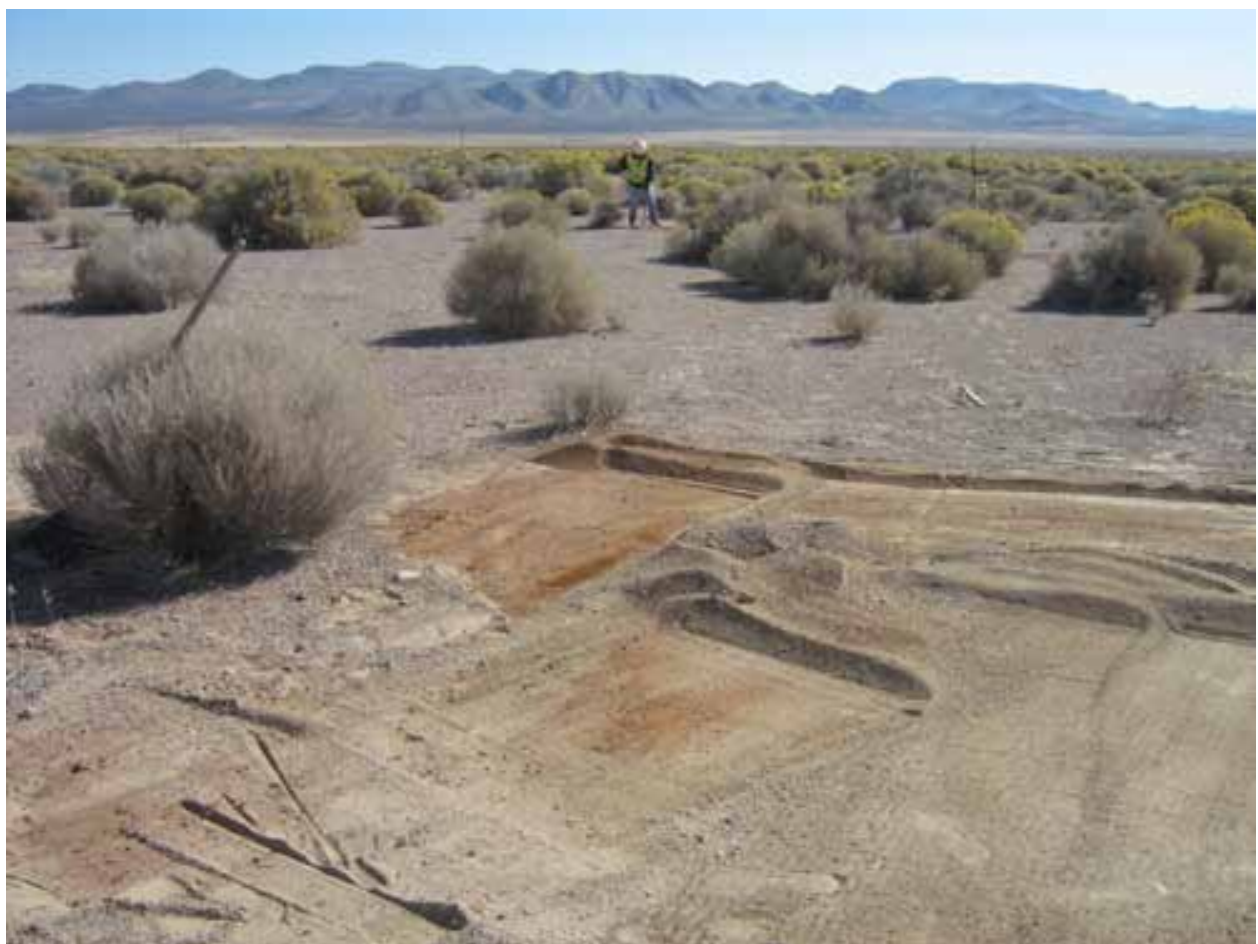

Photograph 2: CAS 02-26-11, Lead Shot, During Closure Activities, 10/26/2011 


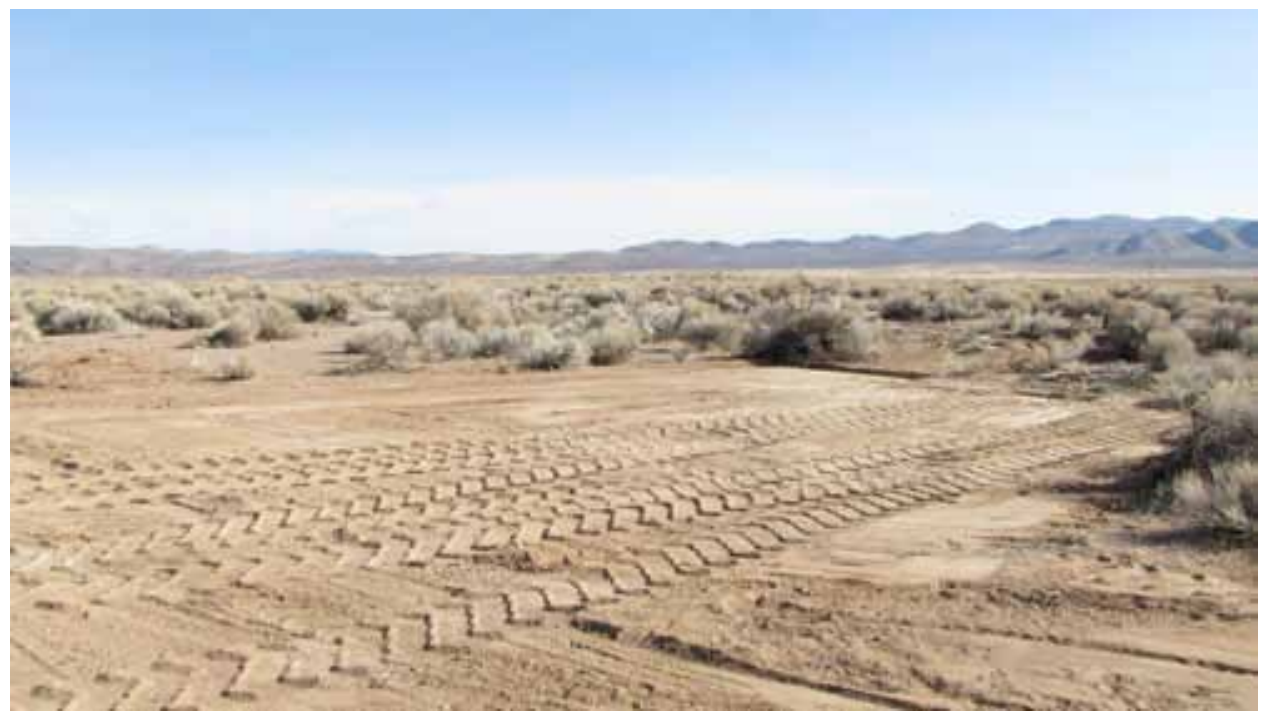

Photograph 3: CAS 02-26-11, Lead Shot, After Closure Activities, 01/18/2012

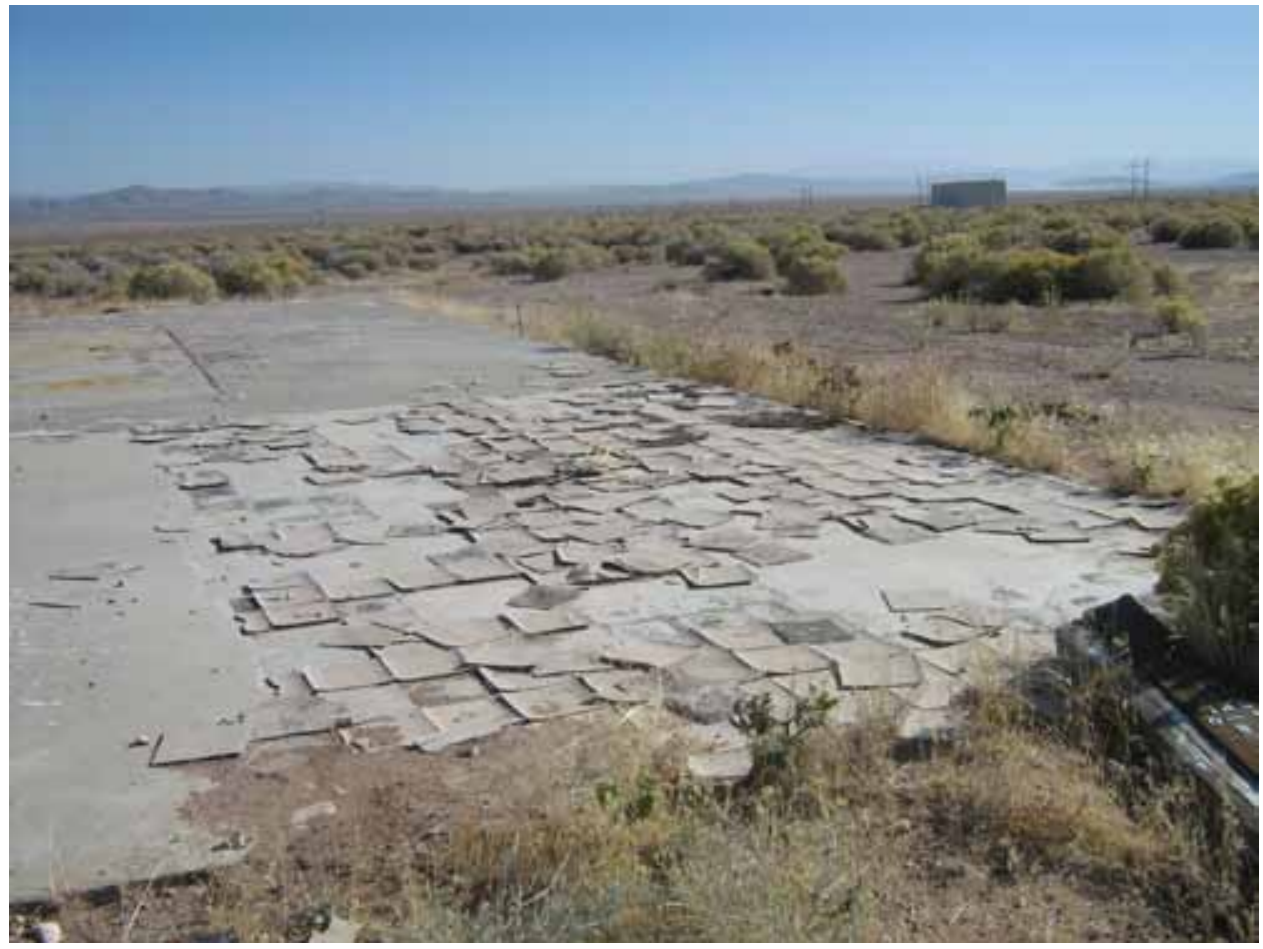

Photograph 4: CAS 02-44-02, Paint Spills and French Drain, Asbestos Tile, 11/01/2011 


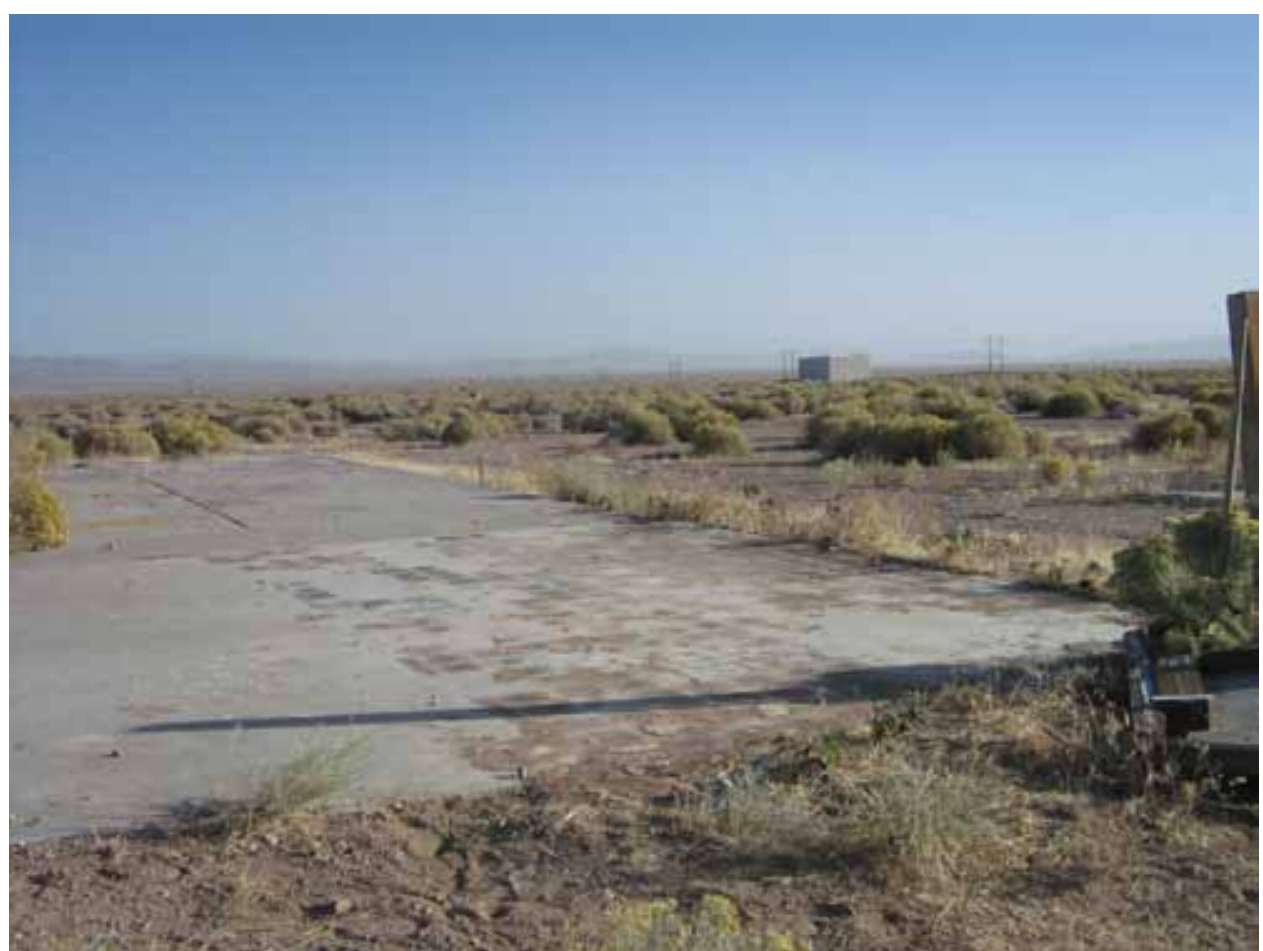

Photograph 5: CAS 02-44-02, Paint Spills and French Drain, After Removal of Asbestos, 11/01/2011

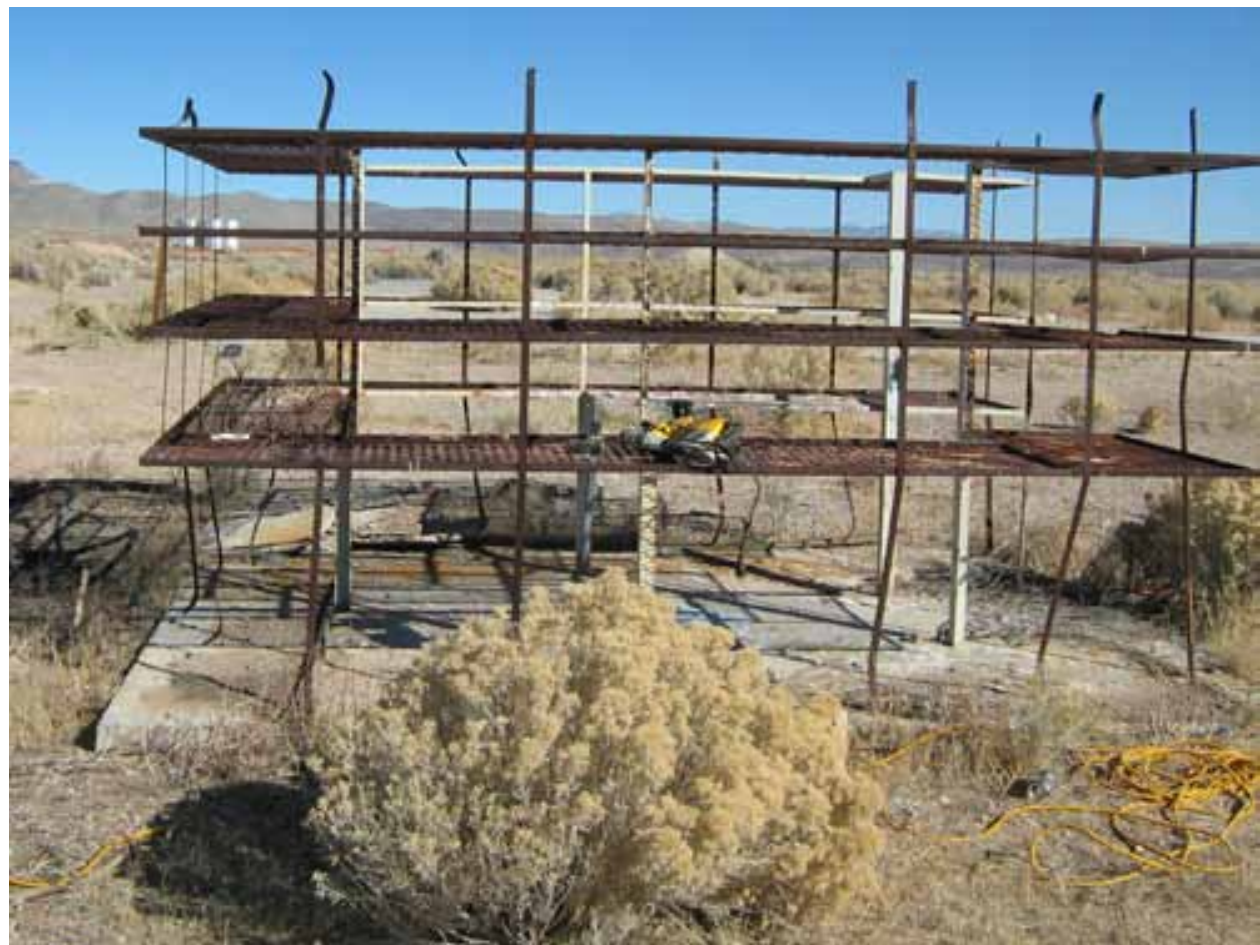

Photograph 6: CAS 02-44-02, Paint Spills and French Drain, Paint Rack, 11/30/2011 


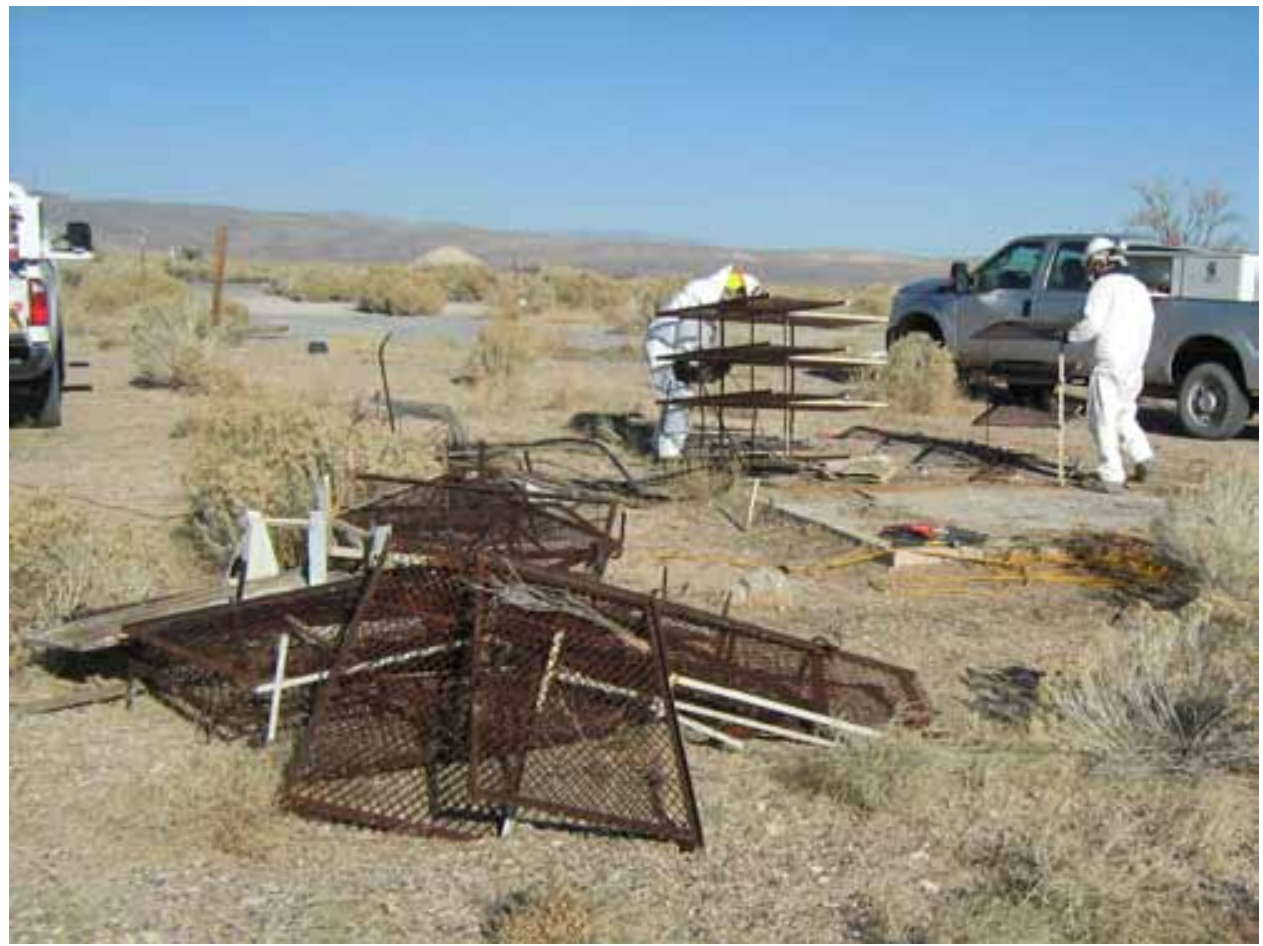

Photograph 7: CAS 02-44-02, Paint Spills and French Drain, Paint Rack Removal, 11/30/2011

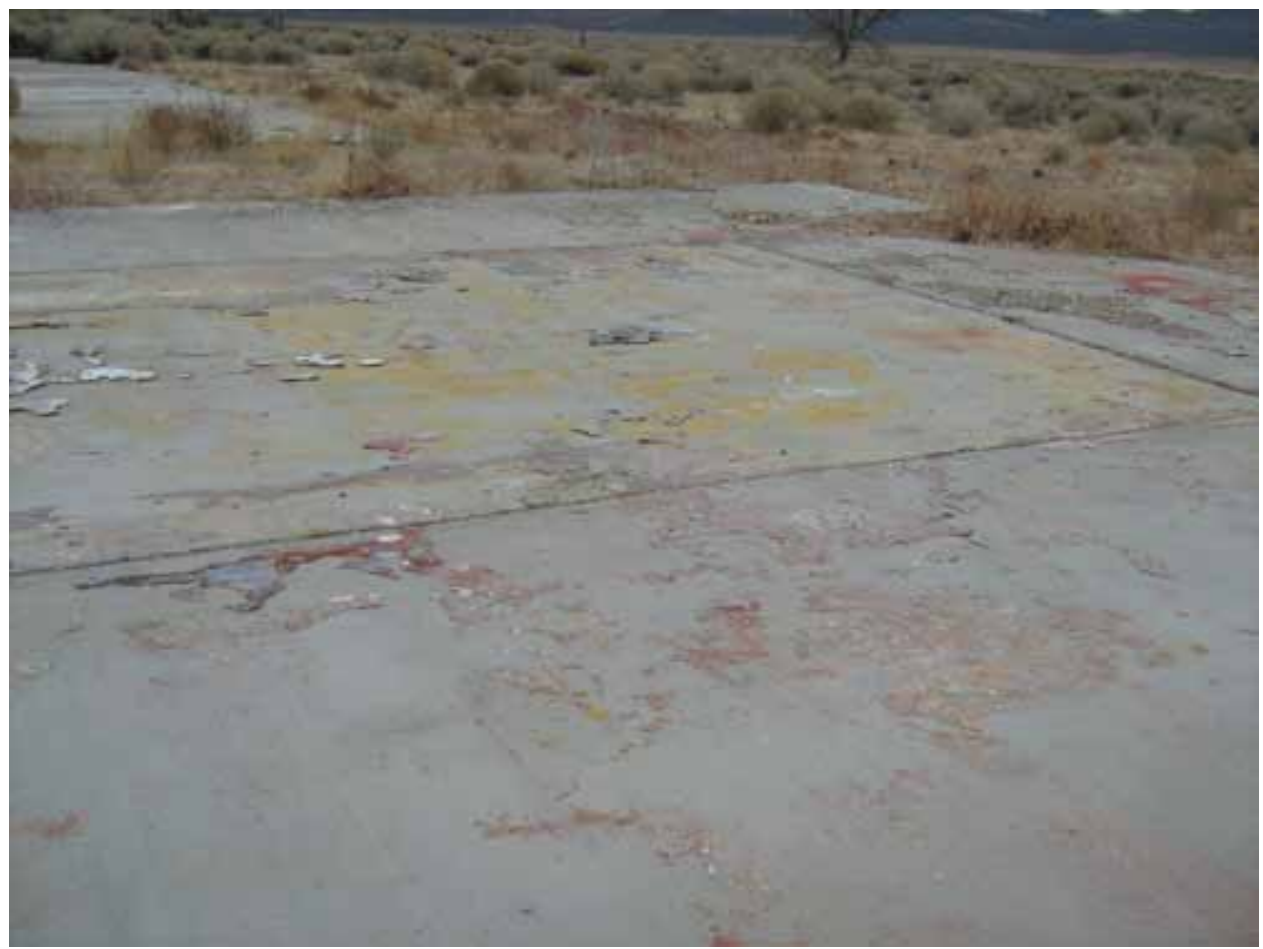

Photograph 8: CAS 02-44-02, Paint Spills and French Drain, Paint on Concrete Pads, 12/15/2011 


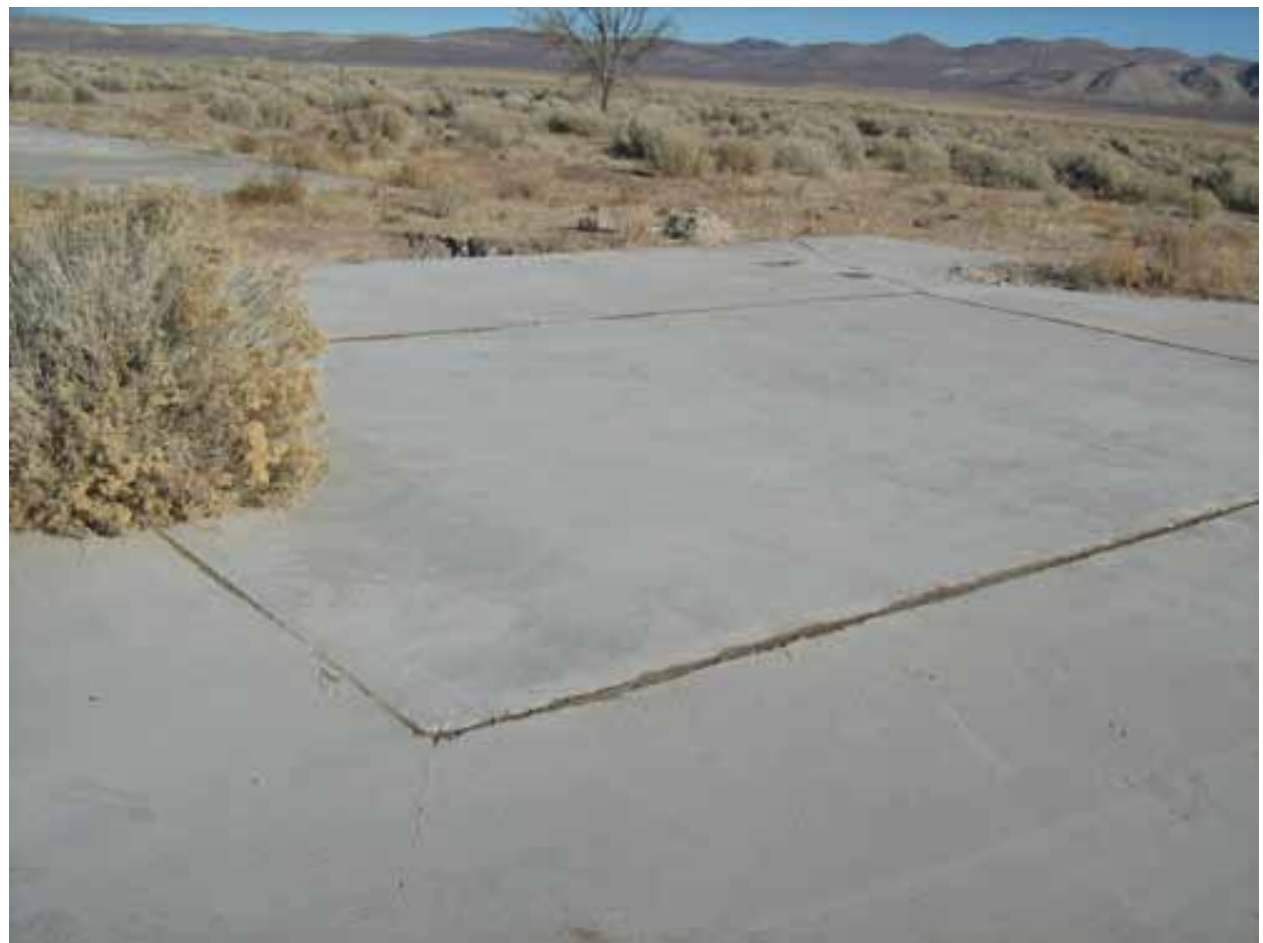

Photograph 9: CAS 02-44-02, Paint Spills and French Drain, After Removal of Paint, 01/12/2012

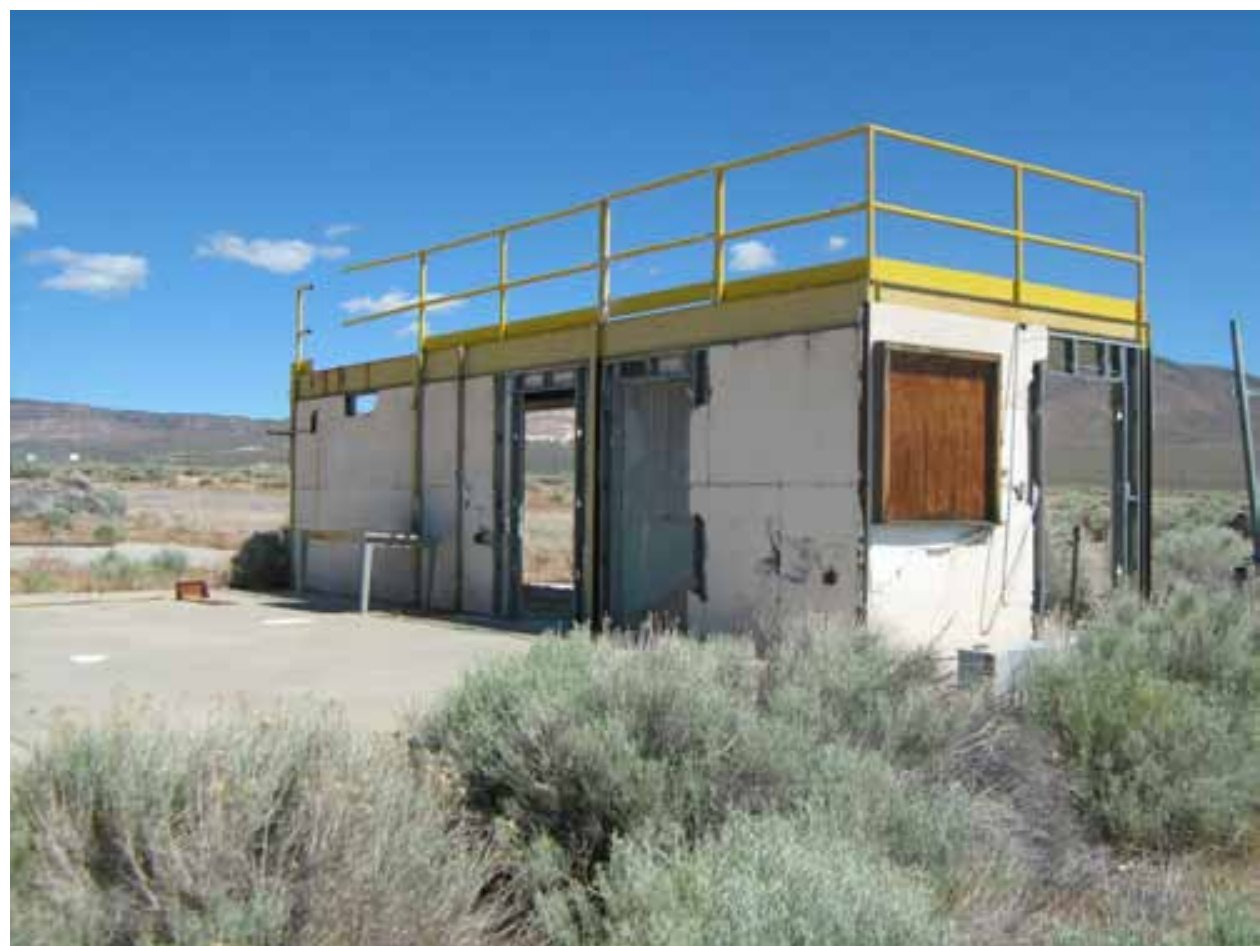

Photograph 10: CAS 02-44-02, Paint Spills and French Drain, Small Building, 06/06/2011 


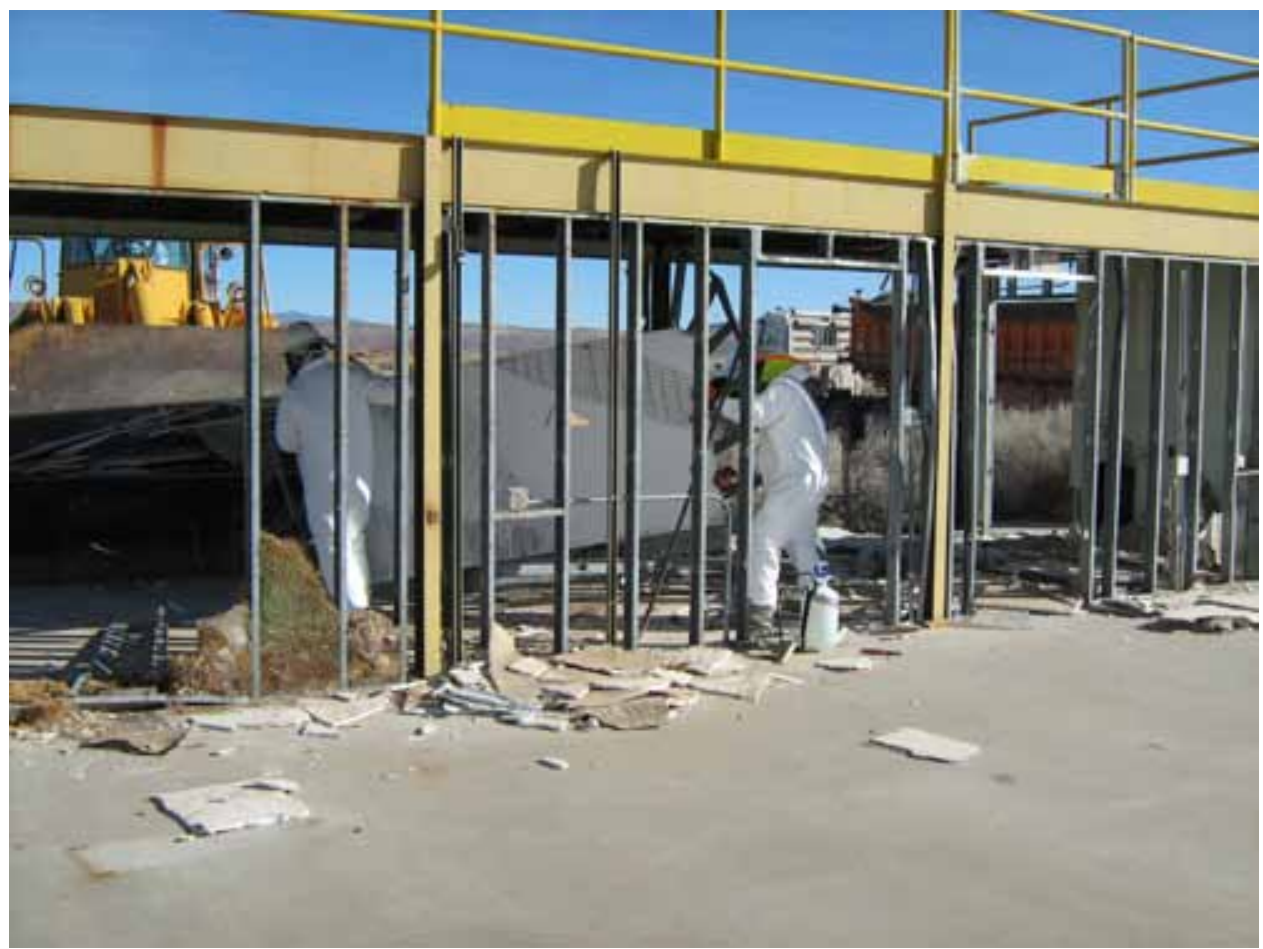

Photograph 11: CAS 02-44-02, Paint Spills and French Drain, Removal of Small Building, 01/03/2012

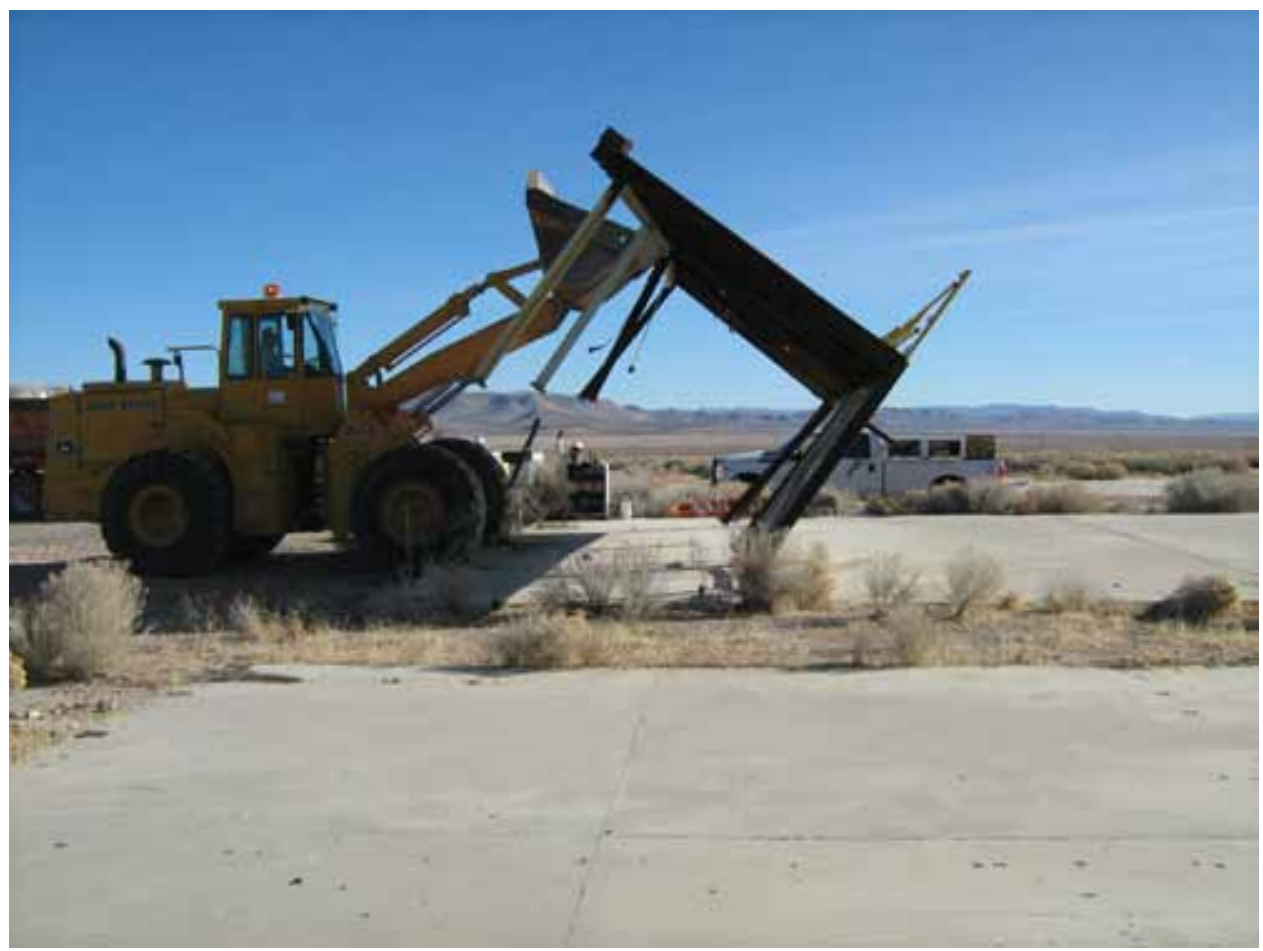

Photograph 12: CAS 02-44-02, Paint Spills and French Drain, Removal of Small Building, 01/03/2012 


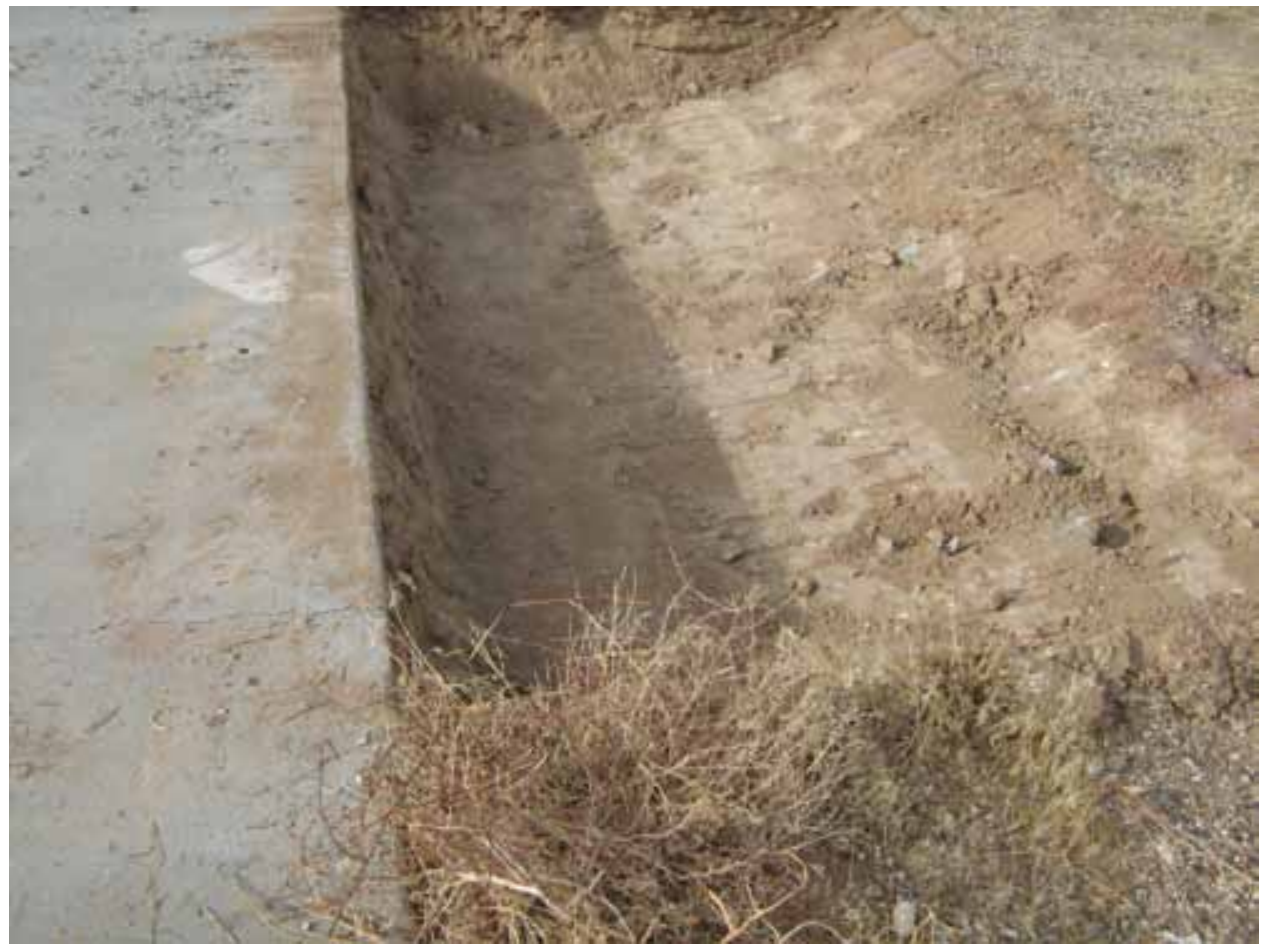

Photograph 13: CAS 02-44-02, Paint Spills and French Drain, Soil Excavation, 12/15/2011

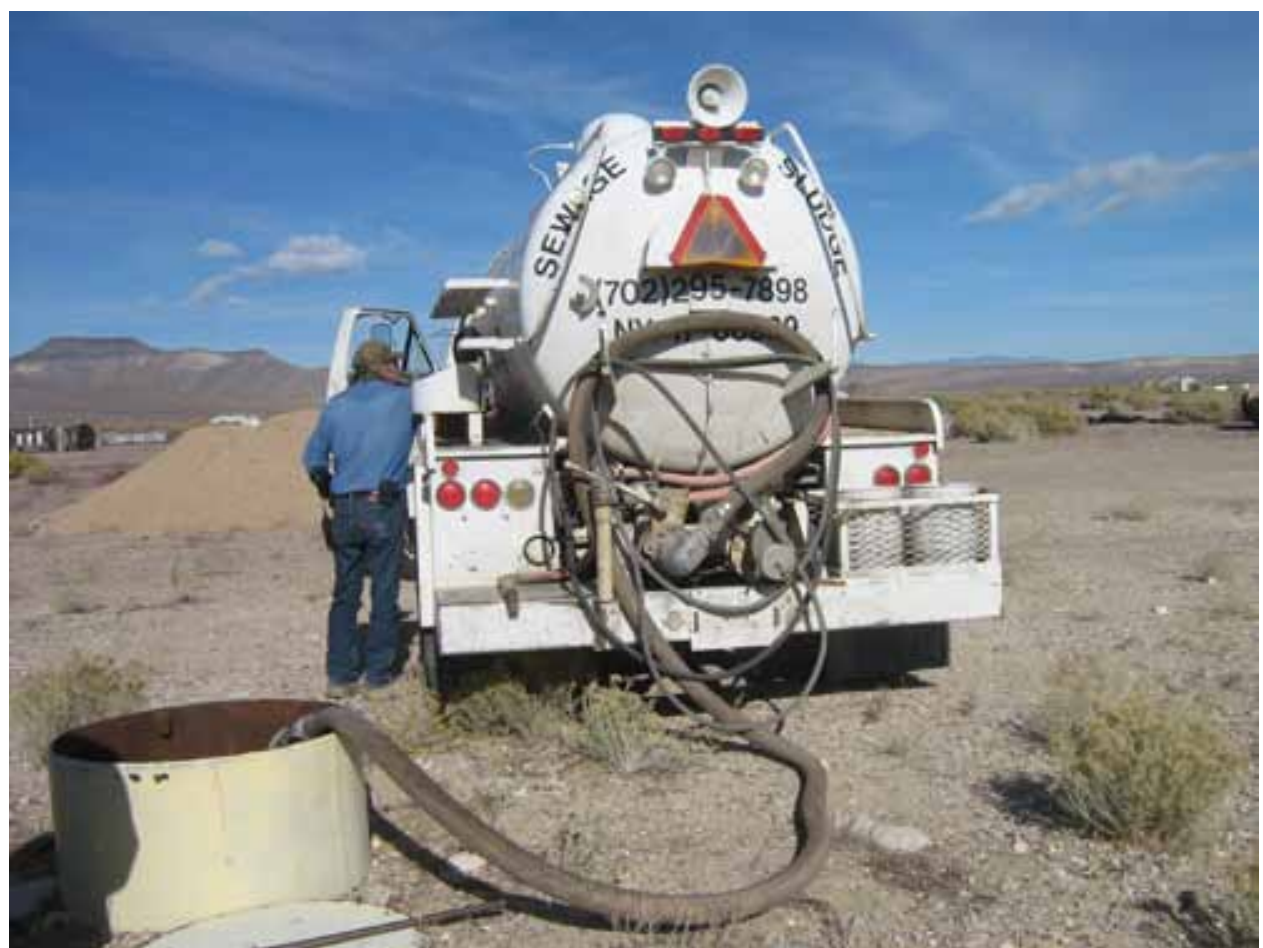

Photograph 14: CAS 02-59-01, Septic System, Pumping Liquid, 11/15/2011 


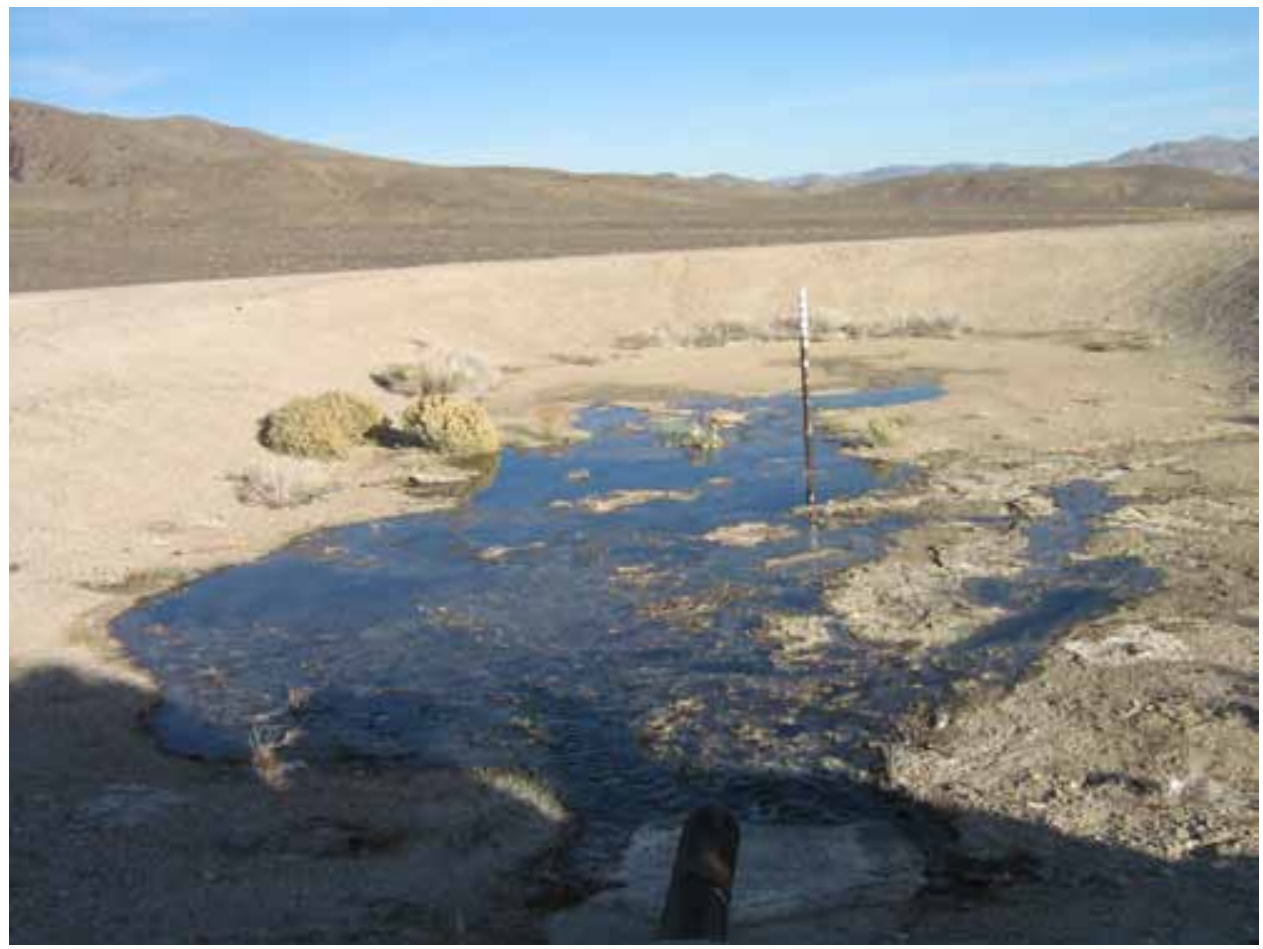

Photograph 15: CAS 02-59-01, Septic System, Disposal of Liquid, 11/15/2011

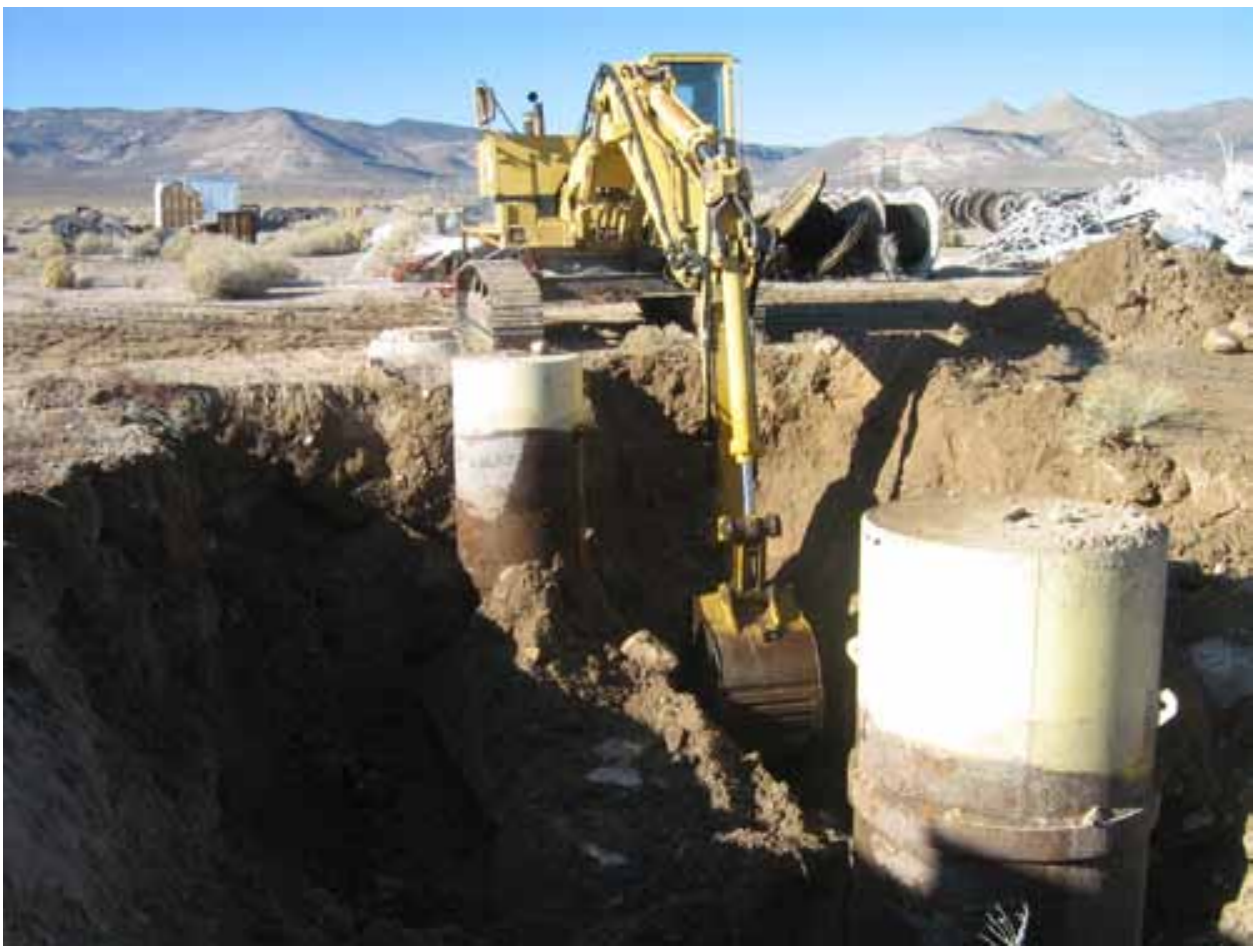

Photograph 16: CAS 02-59-01, Septic System, Excavation of Tank, 12/07/2011 


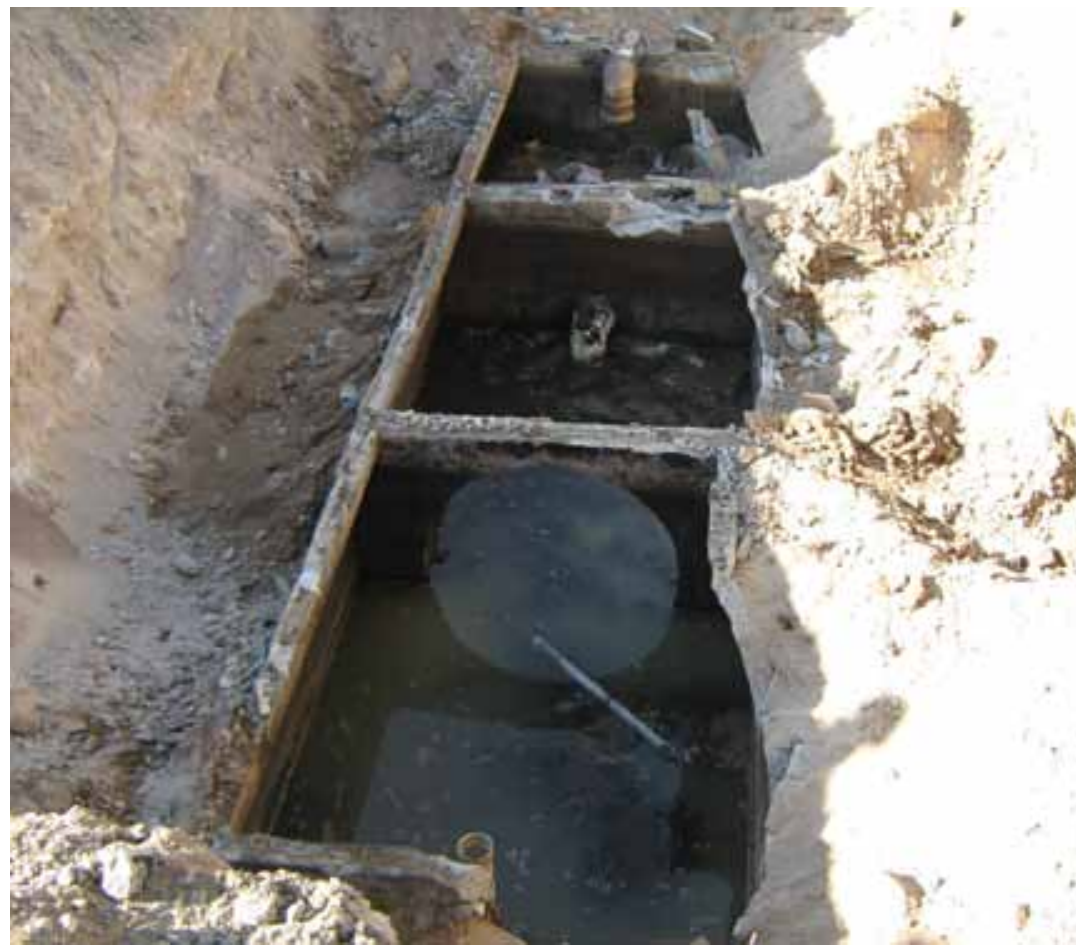

Photograph 17: CAS 02-59-01, Septic System, Tank after Removal of Lids, 12/08/2011

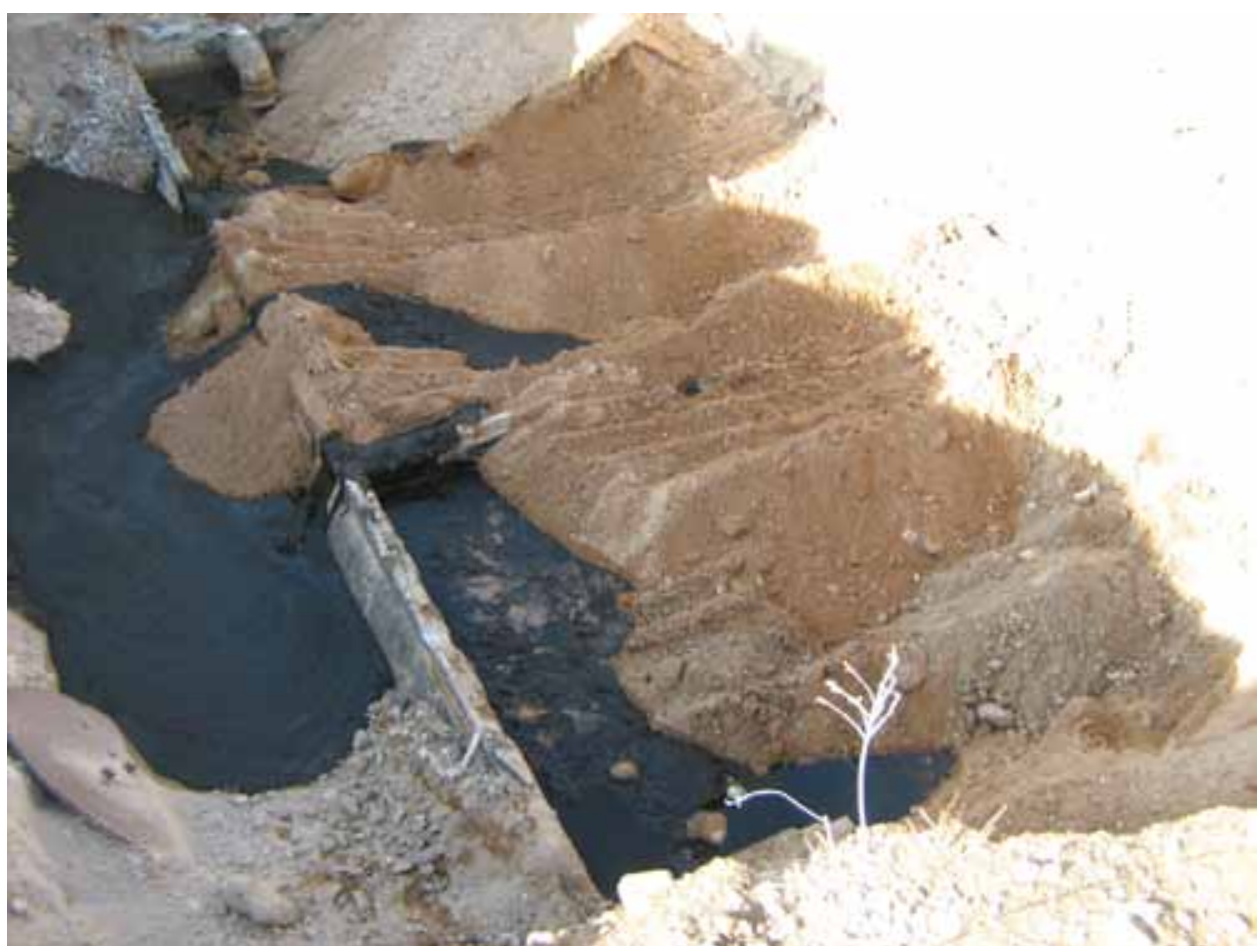

Photograph 18: CAS 02-59-01, Septic System, Solidification of Sludge, 12/08/2011 


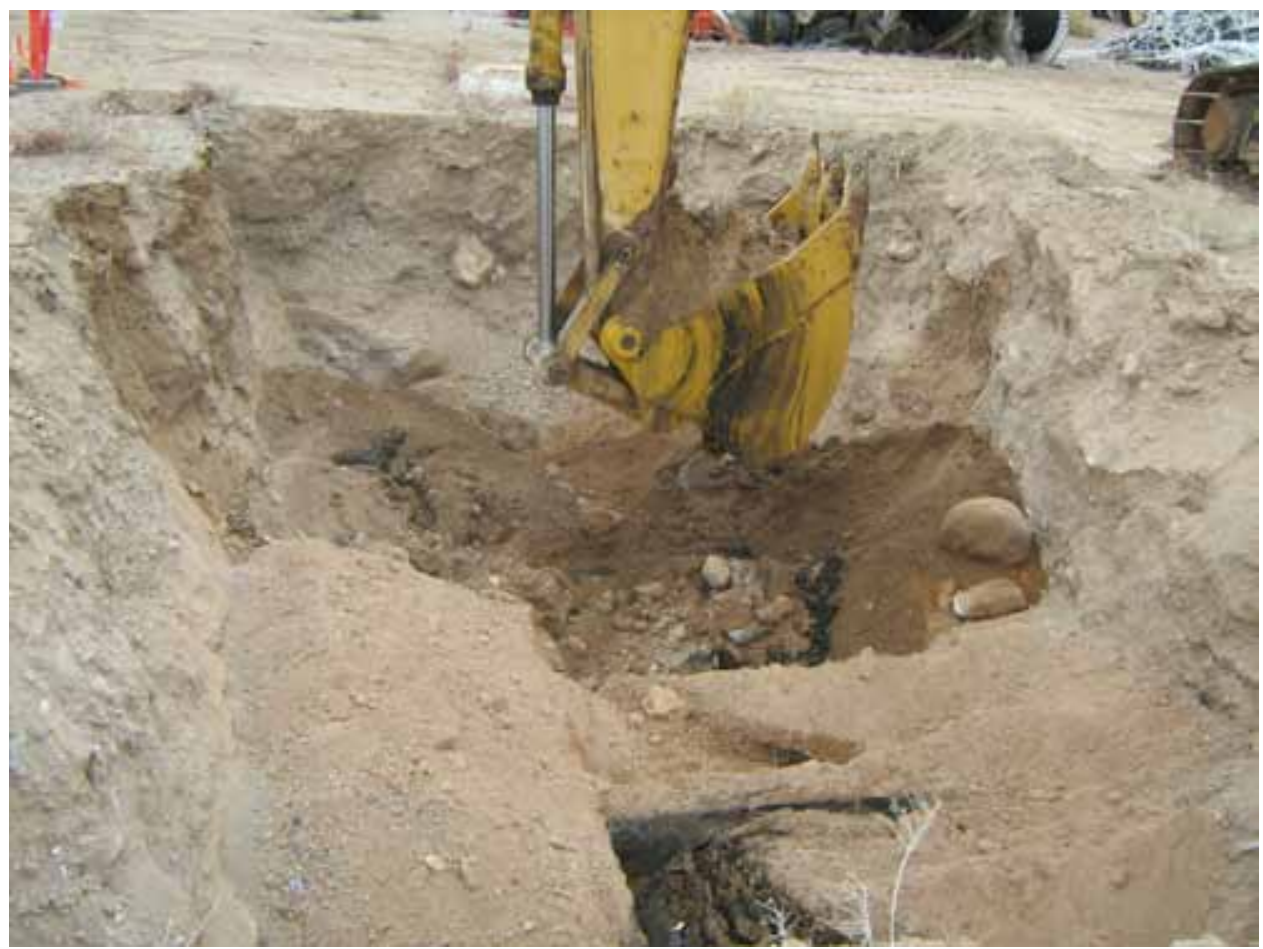

Photograph 19: CAS 02-59-01, Septic System,

Removal of Solidified Sludge and Tank, 12/12/2011

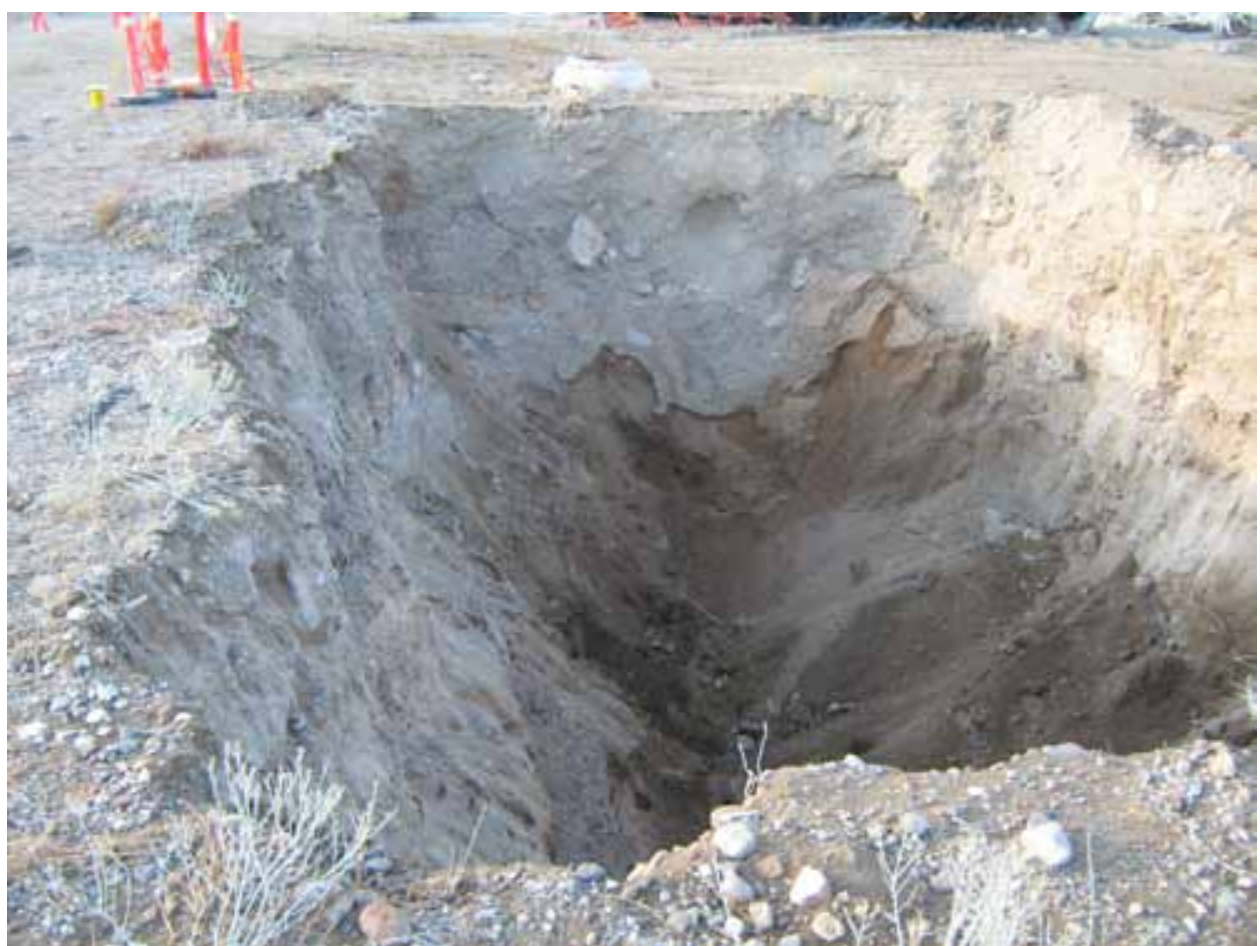

Photograph 20: CAS 02-59-01, Septic System, Excavation after Removal of Tank, 12/13/2011 


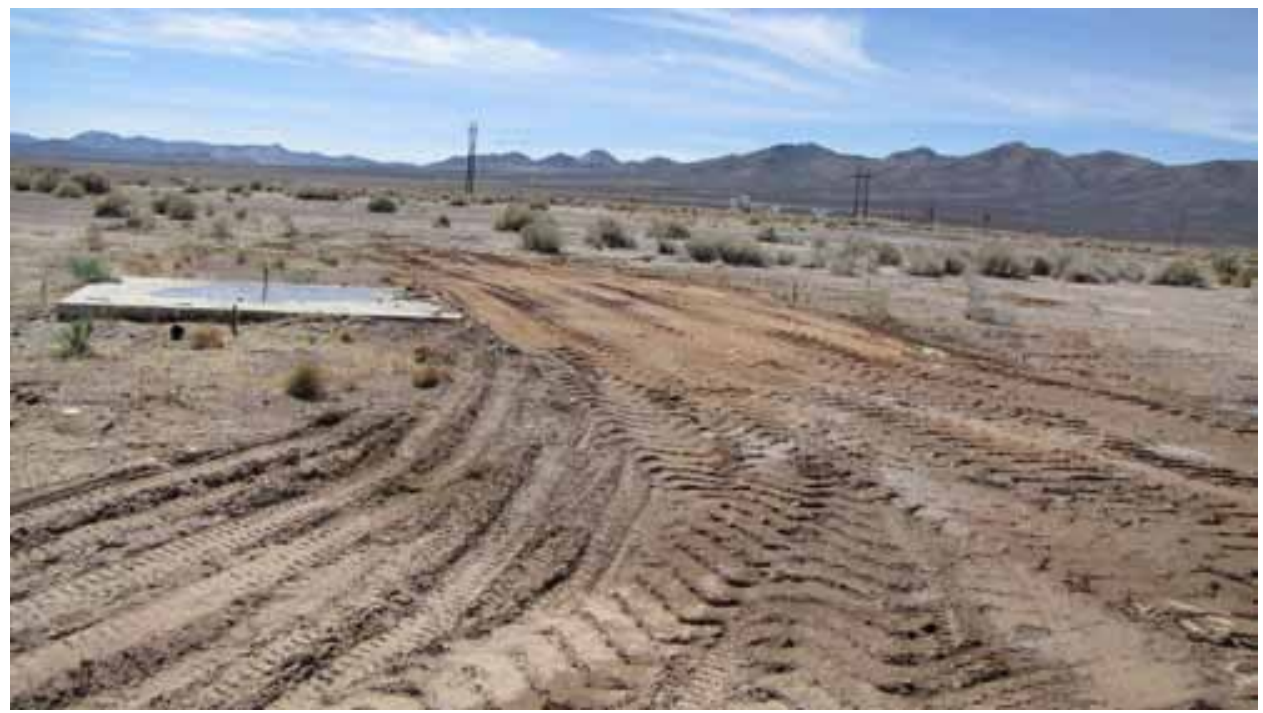

Photograph 21: CAS 02-60-03, Steam Cleaning Drain, Backfilled Excavation, 04/02/2012

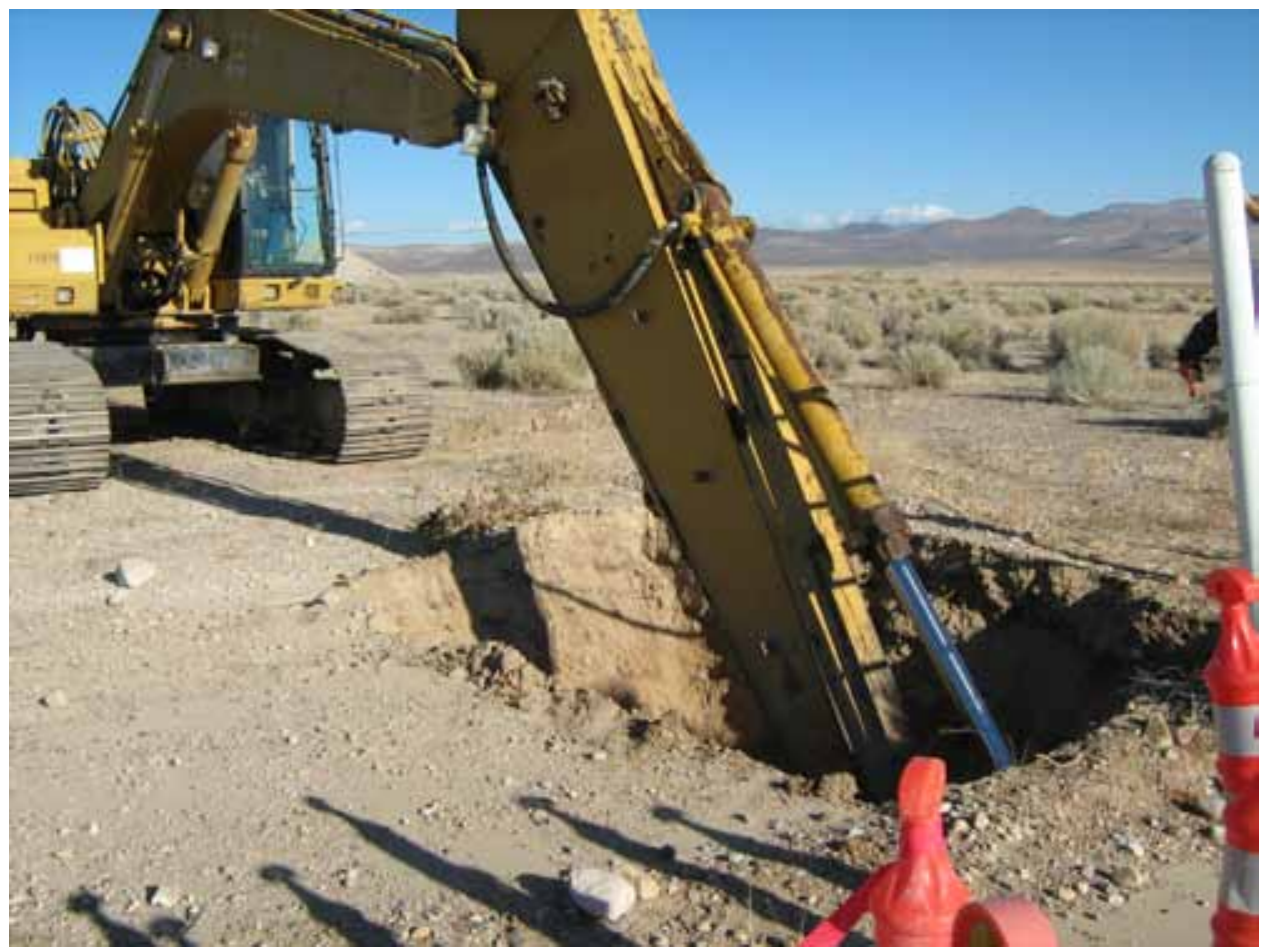

Photograph 22: CAS 02-60-05, French Drain, Excavation of Soil, 12/14/2011 


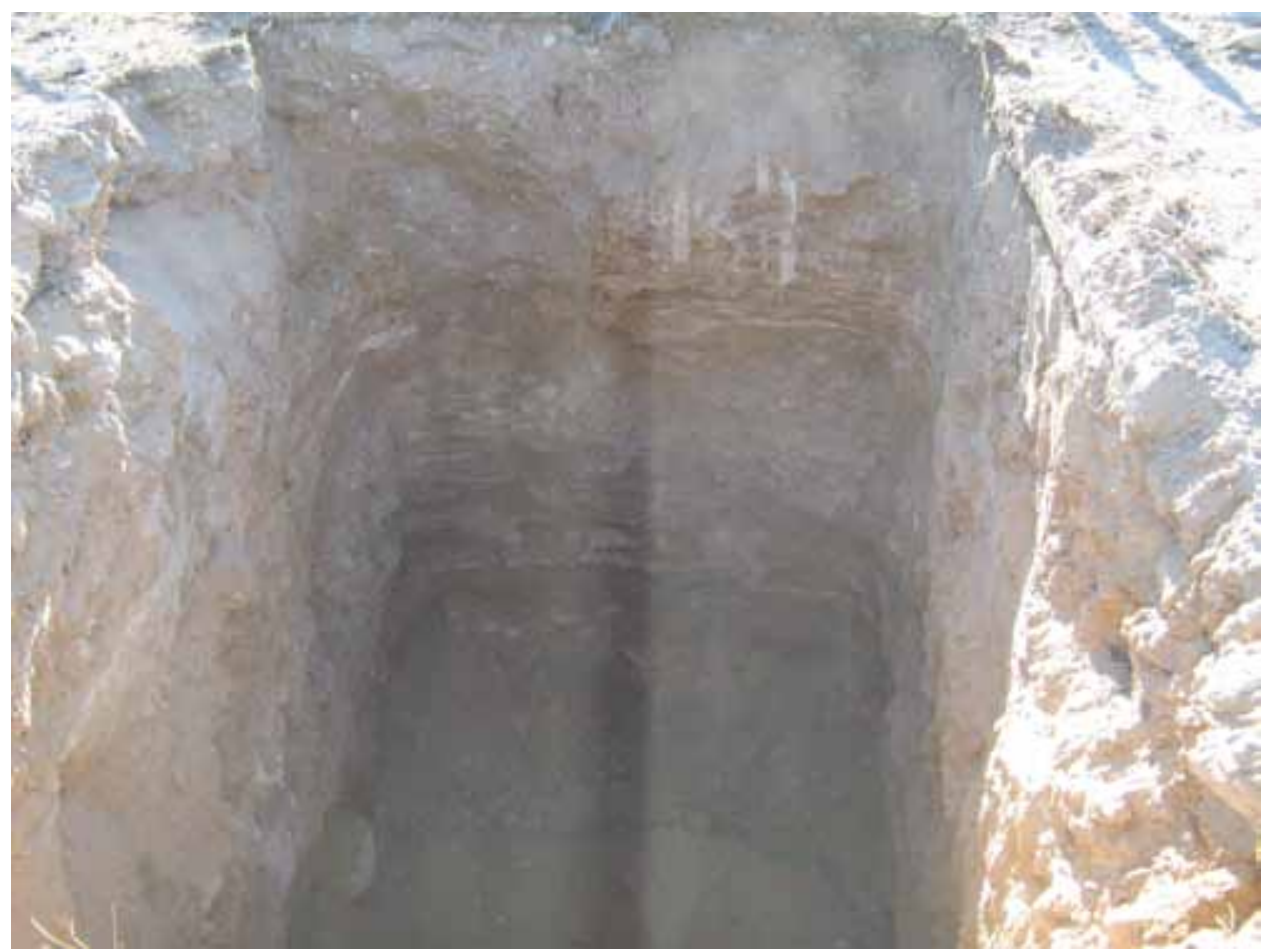

Photograph 23: CAS 02-60-05, French Drain, Soil Excavation, 12/14/2011

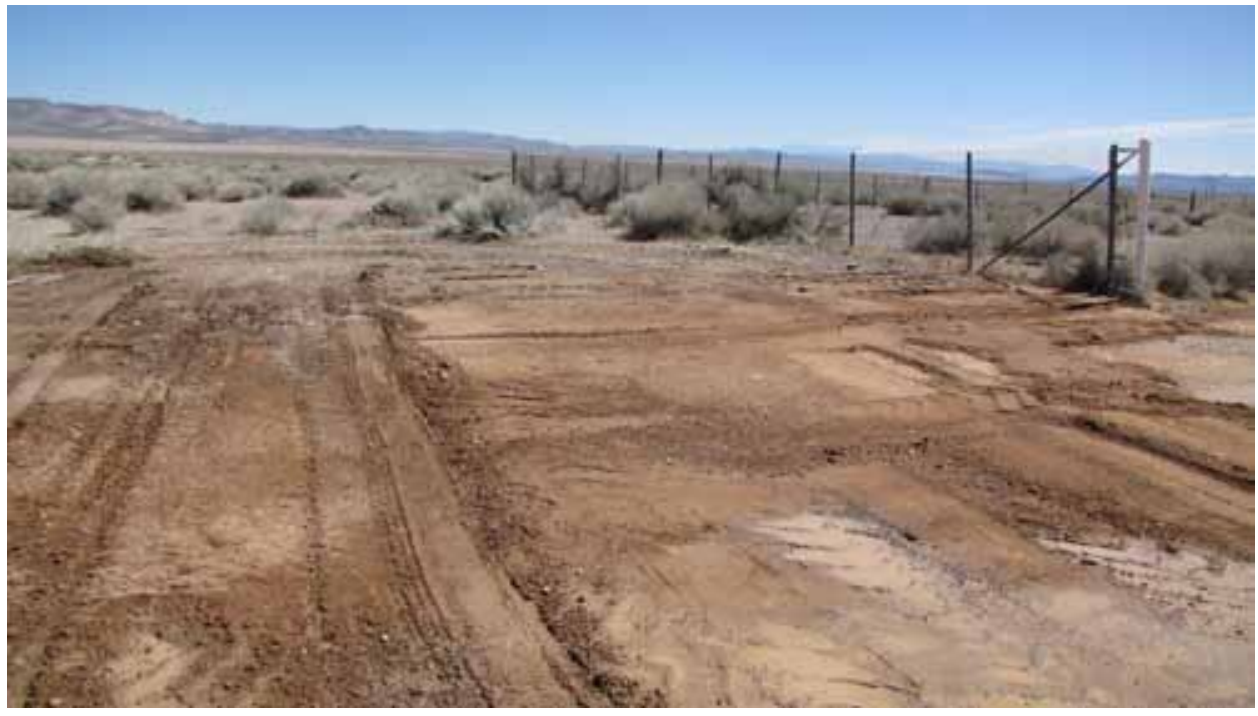

Photograph 24: CAS 02-60-05, French Drain, Backfilled Excavation, 04/02/2012 


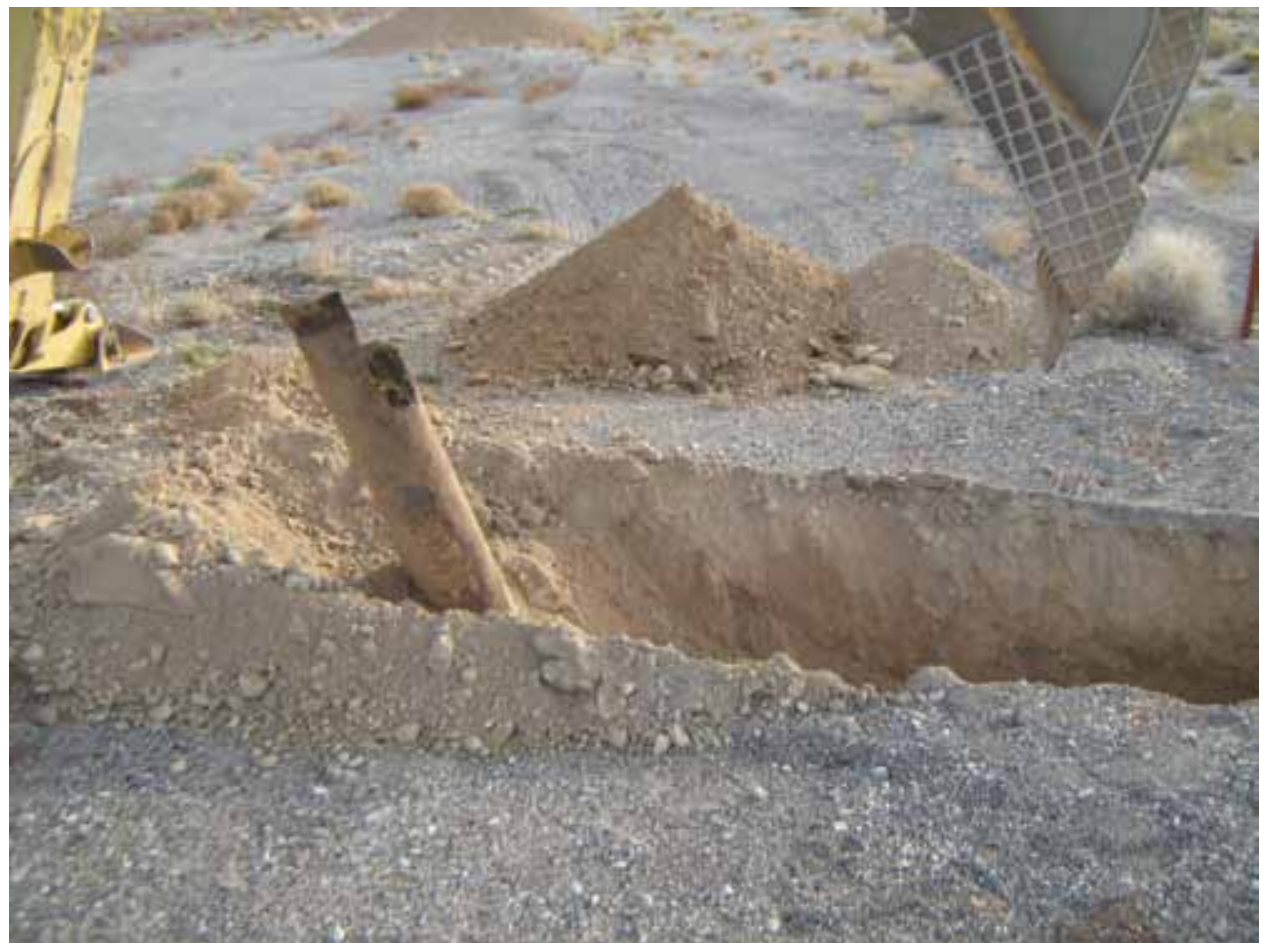

Photograph 25: CAS 23-60-01, Mud Trap Drain and Outfall, Removal of Outfall Pipe, 01/19/2012

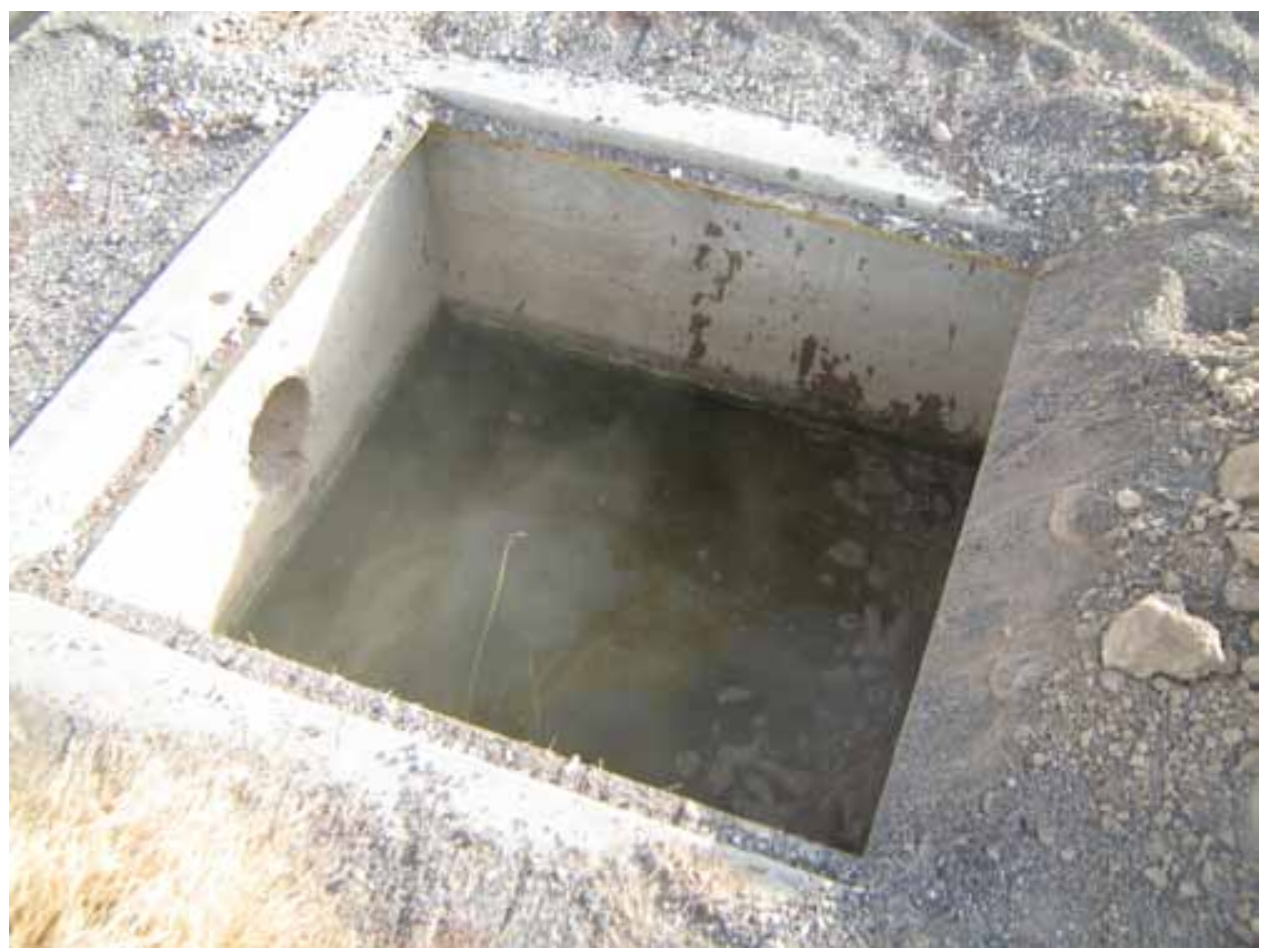

Photograph 26: CAS 23-60-01, Mud Trap Drain and Outfall, Mud Trap, 01/19/2012 


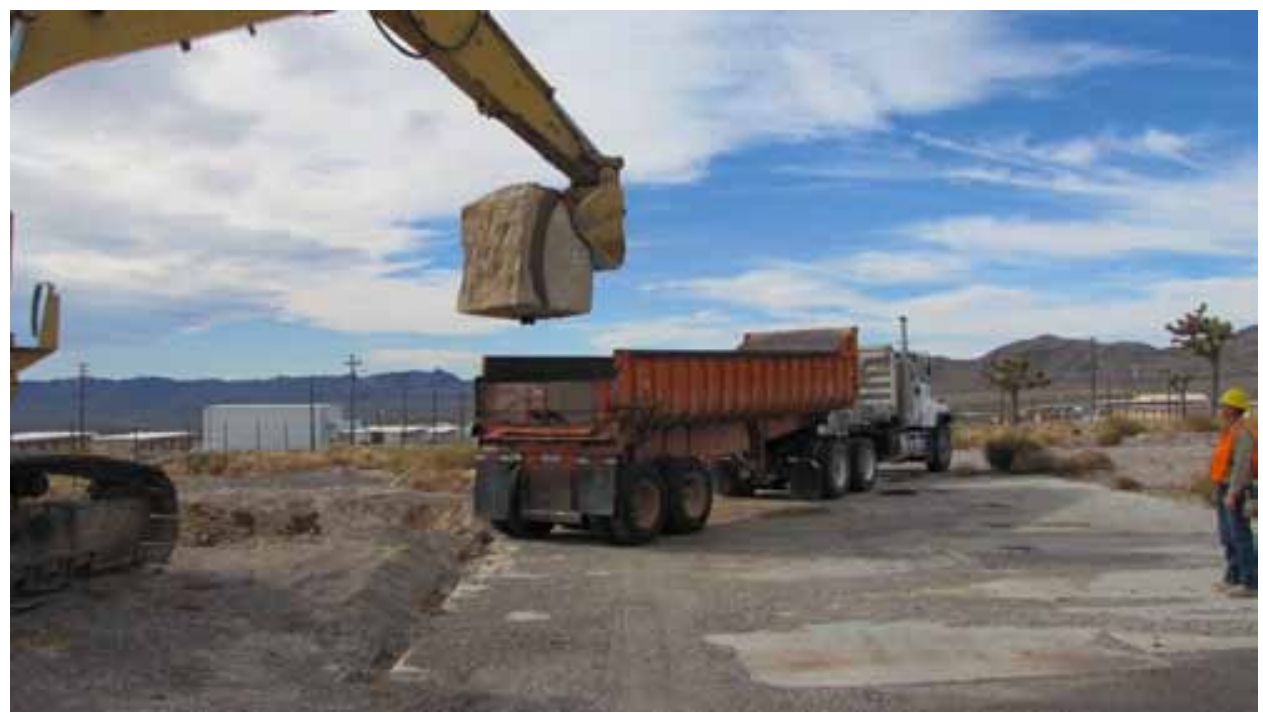

Photograph 27: CAS 23-60-01, Mud Trap Drain and Outfall, Removal of Mud Trap, 01/19/2012

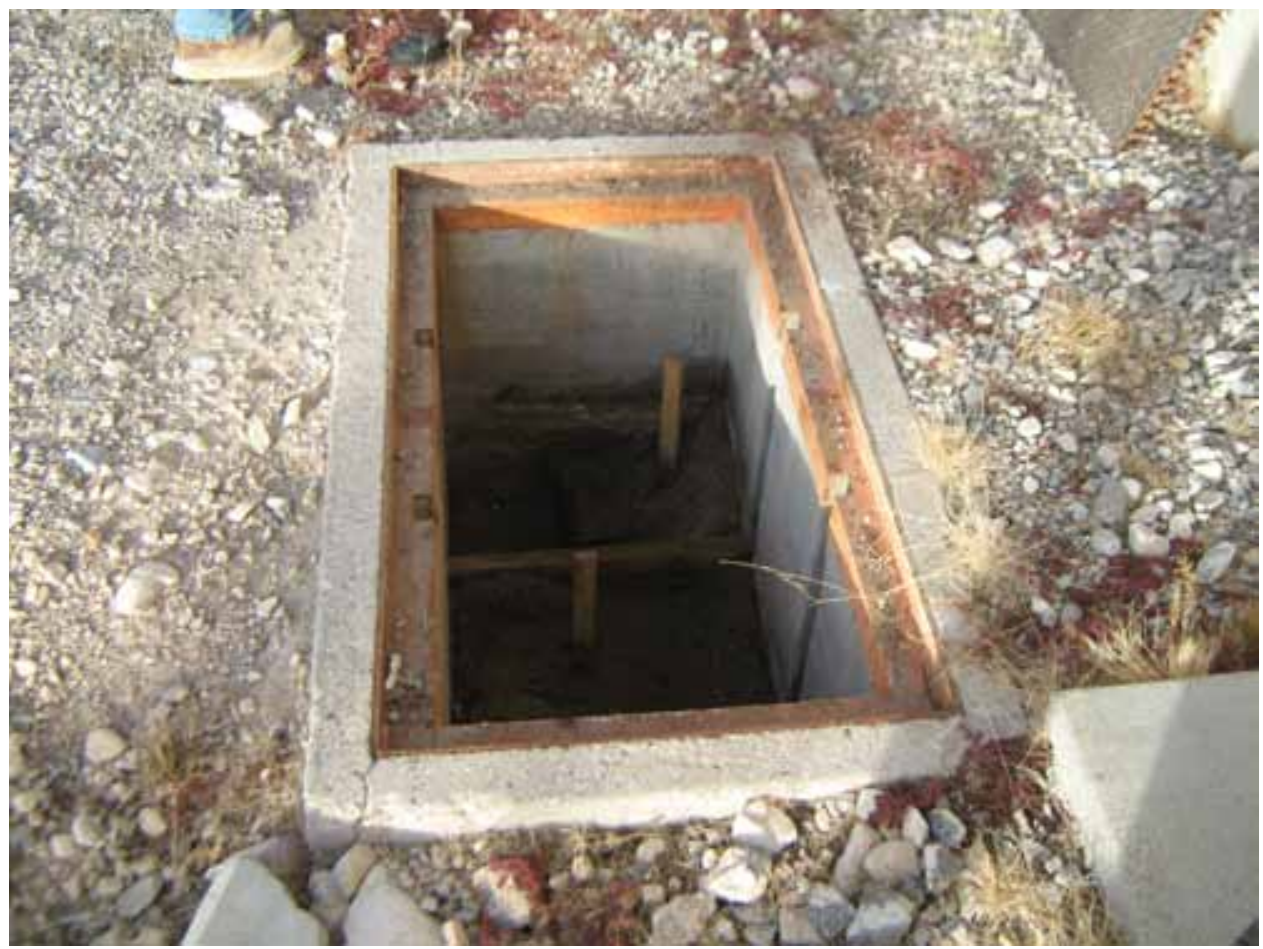

Photograph 28: CAS 23-99-06, Grease Trap, Before Removal of Sediment, 01/19/2012 


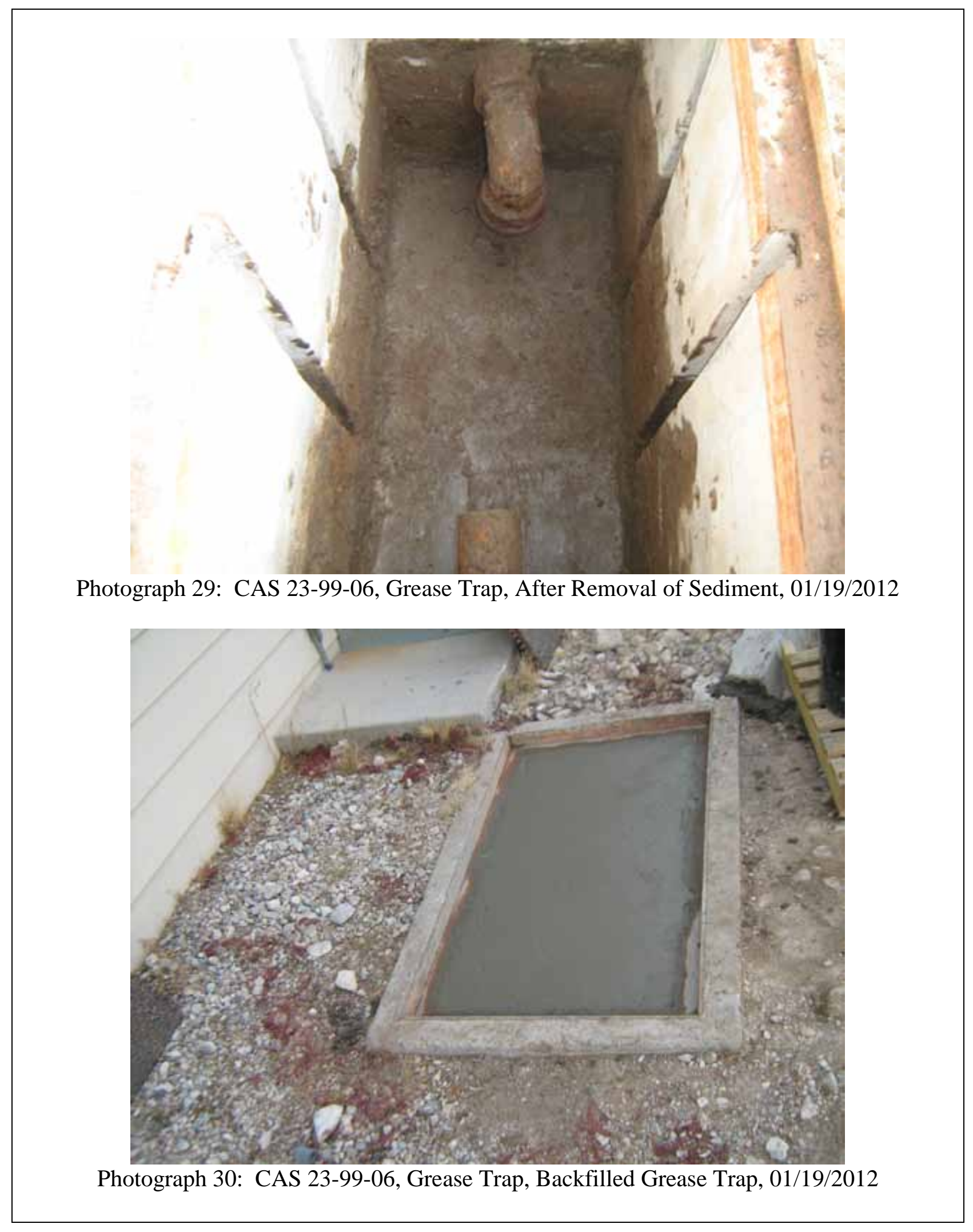




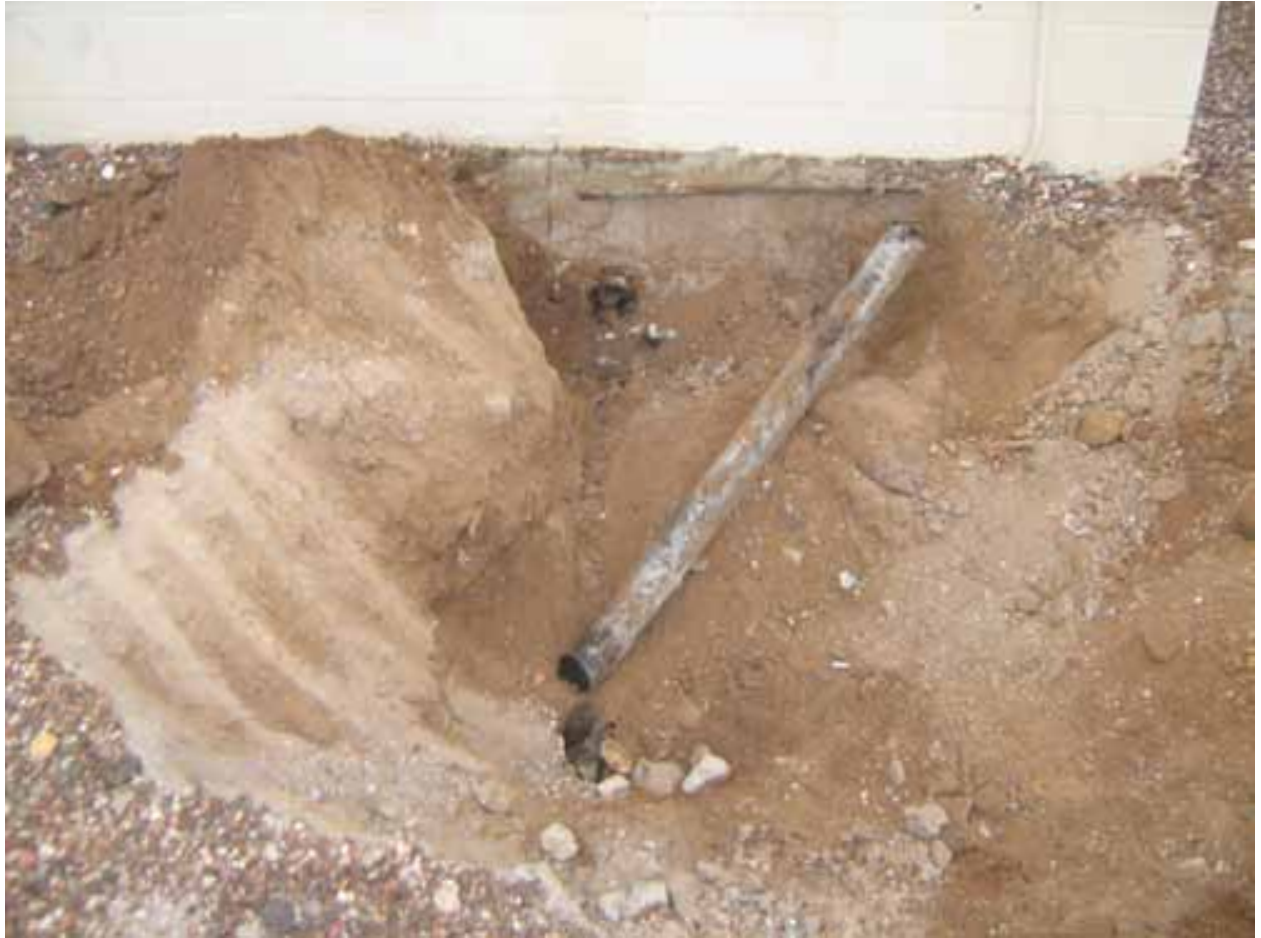

Photograph 31: CAS 25-60-04, Building 3123 Outfalls, Outfall Pipe, 01/23/2012

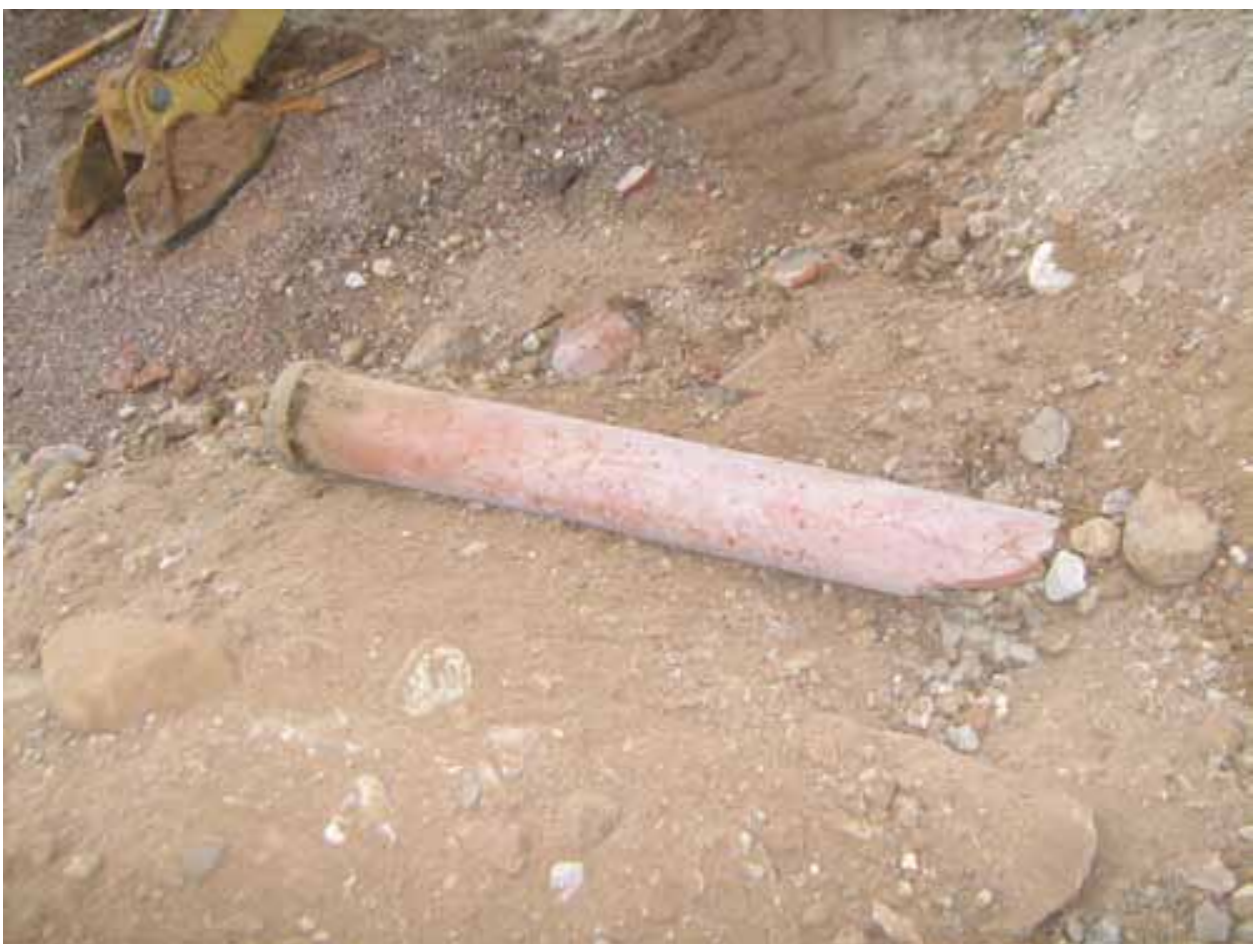

Photograph 32: CAS 25-60-04, Building 3123 Outfalls, Outfall Pipe, 01/23/2012 


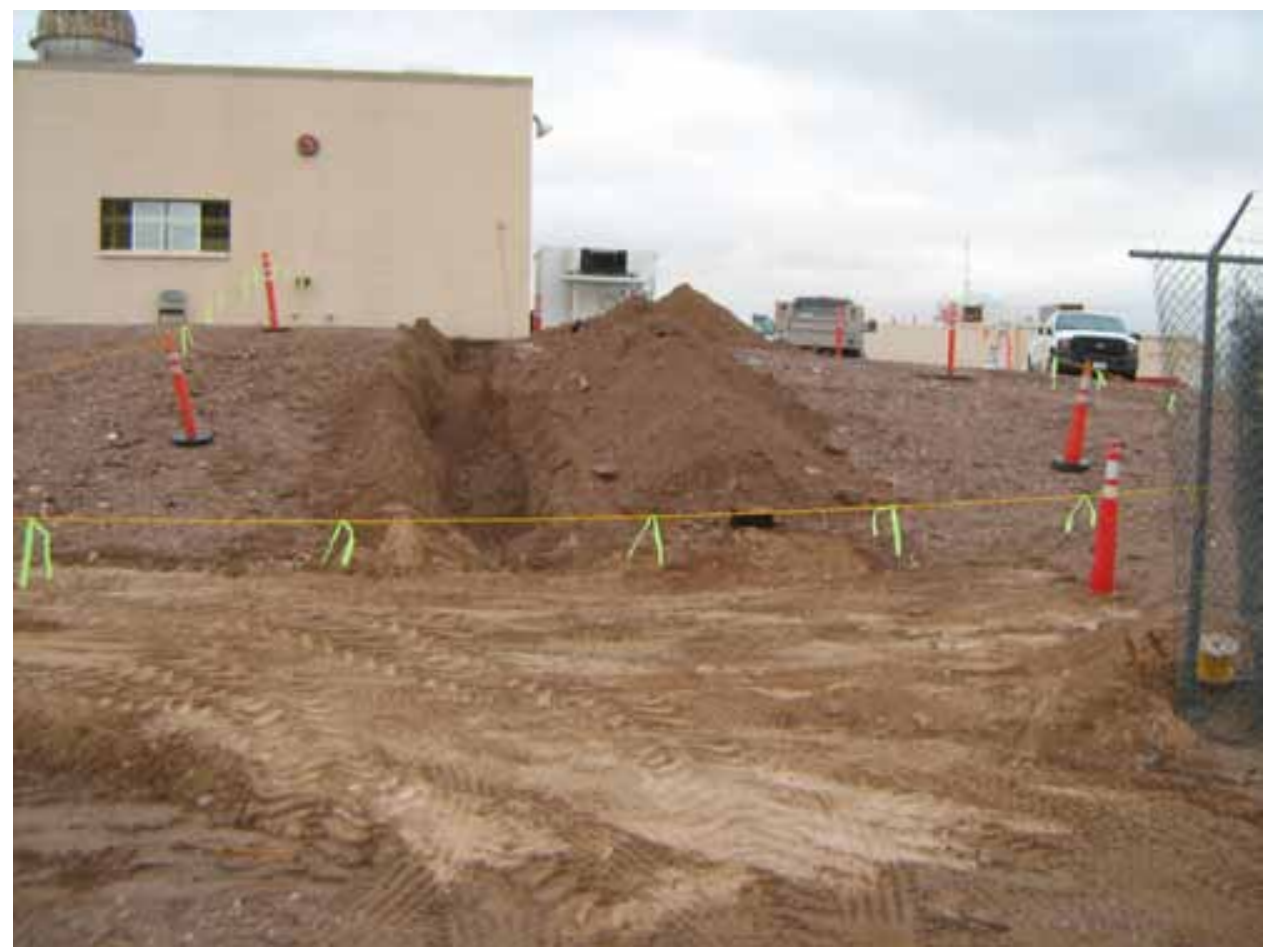

Photograph 33: CAS 25-60-04, Building 3123 Outfalls, After Removal of Outfall Pipe, 01/23/2012

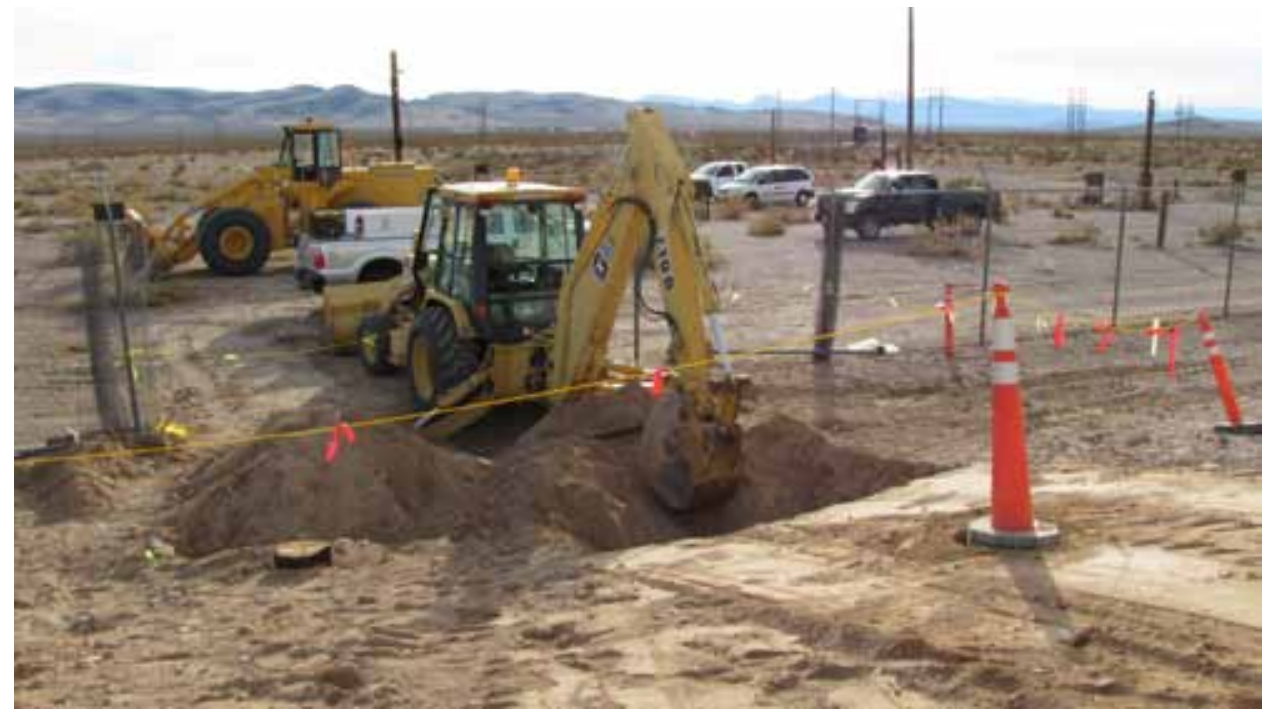

Photograph 34: CAS 25-60-04, Building 3123 Outfalls, Excavation of Soil, 01/24/2012 


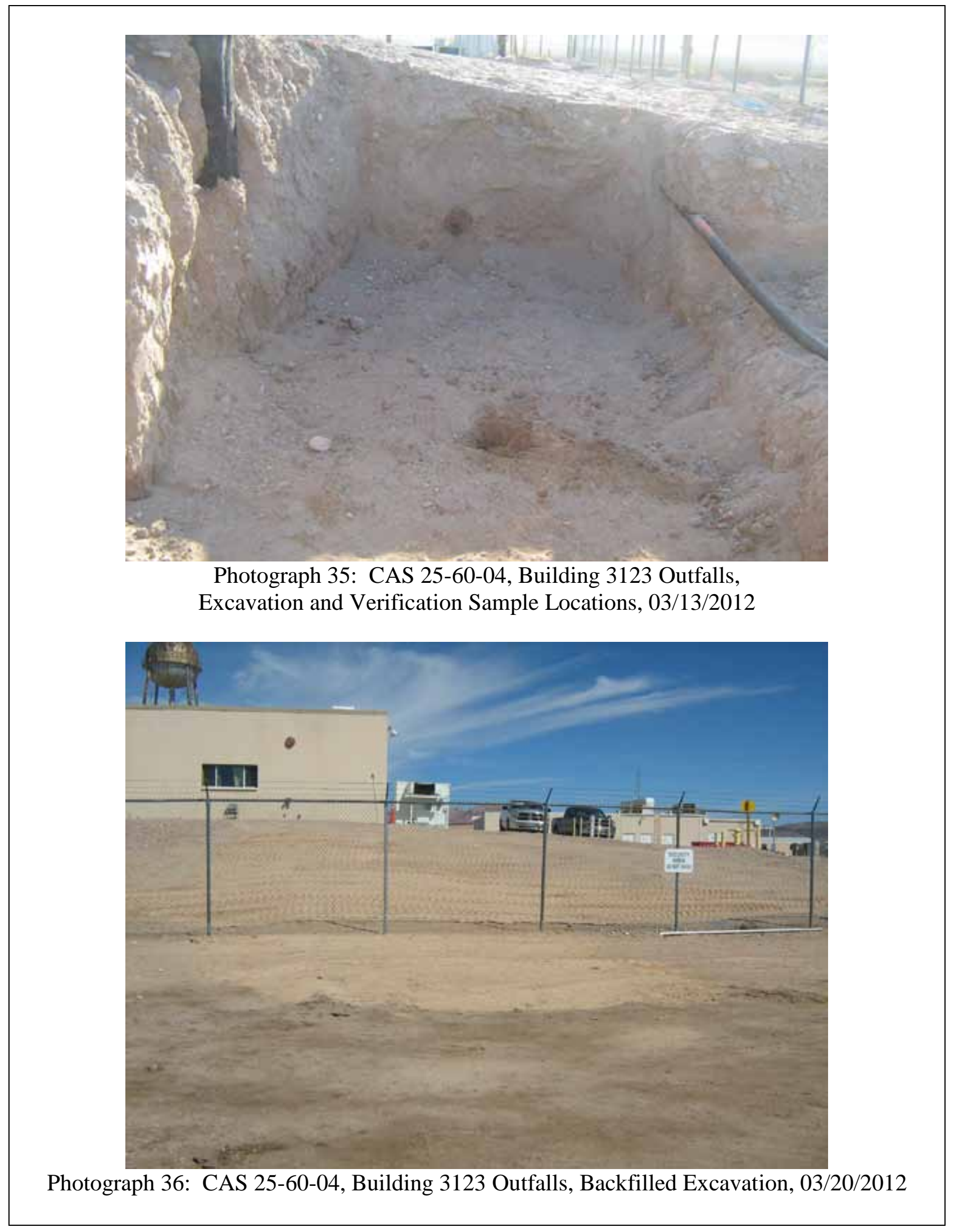


CAU 562 Closure Report

Section: Library Distribution List

Revision: 0

Date: August 2012

\section{LIBRARY DISTRIBUTION LIST}


CAU 562 Closure Report

Section: Library Distribution List

Revision: 0

Date: August 2012

THIS PAGE INTENTIONALLY LEFT BLANK 


\section{LIBRARY DISTRIBUTION LIST}

U.S. Department of Energy

National Nuclear Security Administration

Nevada Site Office

Technical Library

P.O. Box 98518, M/S 505

Las Vegas, NV 89193-8518

U.S. Department of Energy

Office of Scientific and Technical Information

P.O. Box 62

Oak Ridge, TN 37831-0062

Southern Nevada Public Reading Facility

c/o Nuclear Testing Archive

P.O. Box 98521, M/S 400

Las Vegas, NV 89193-8521

Manager, Northern Nevada FFACO

Public Reading Facility

c/o Nevada State Library \& Archives

Carson City, NV 89701-4285
1 (Uncontrolled, electronic copy)

1 (Uncontrolled, electronic copy)

2 (Uncontrolled, electronic copies)

1 (Uncontrolled, electronic copy) 
CAU 562 Closure Report

Section: Library Distribution List

Revision: 0

Date: August 2012

THIS PAGE INTENTIONALLY LEFT BLANK 